UNIVERSIDADE DE SÃO PAULO

FACULDADE DE ECONOMIA, ADMINISTRAÇÃO E CONTABILIDADE DEPARTAMENTO DE ADMINISTRAÇÃO

PROGRAMA DE MESTRADO PROFISSIONAL EM EMPREENDEDORISMO

O POTENCIAL DE INDIVÍDUOS PARA A MOBILIZAÇÃO DE DOAÇÕES ONLINE: UM ESTUDO COMPARATIVO ENTRE BRASIL E ESTADOS-UNIDOS.

Fernanda Camargo Giannini

Orientadora: Profa Dra Graziella Maria Comini 
Prof. Dr. Marco Antonio Zago

Reitor da Universidade de São Paulo

Prof. Dr. Adalberto Américo Fischmann

Diretor da Faculdade de Economia, Administração e Contabilidade

Prof. Dr.Roberto Sbragia

Chefe do Departamento de Administração

Prof. Dr. Martinho Isnard Ribeiro de Almeida

Coordenador do Programa de Mestrado Profissional em Empreendedorismo 


\section{O POTENCIAL DE INDIVÍDUOS PARA A MOBILIZAÇÃO DE DOAÇÕES ONLINE: UM ESTUDO COMPARATIVO ENTRE BRASIL E ESTADOS-UNIDOS.}

Dissertação apresentada ao Programa de Mestrado Profissional em Empreendedorismo, do Departamento de Administração da Faculdade de Economia, Administração e Contabilidade da Universidade de São Paulo, como requisito parcial para a obtenção do título de Mestre em Ciências.

\section{Orientadora: Prof. Dra. Graziella Maria Comini}

\section{Versão Corrigida}

(versão original disponível na Biblioteca da Faculdade de Economia, Administração e Contabilidade) 
FICHA CATALOGRÁFICA

Elaborada pela Seção de Processamento Técnico do SBD/FEA/USP

Giannini, Fernanda Camargo

O potencial de indivíduos para a mobilização de doações online: um estudo comparativo entre Brasil e Estados Unidos / Fernanca Camargo Giannini. - São Paulo, 2017.

$213 p$.

Dissertação (Mestrado) - Universidade de São Paulo, 2017.

Orientador: Graziella Maria Comini.

1. Captação de recursos financeiros 2. E-filantropia 3. Captação de recursos online 4. Captação de recursos peer-to-peer I. Universidade de São Paulo. Faculdade de Economia, Administração e Contabilidade. II. Título. 
Para Deus, o maior Empreendedor que existe. 


\section{AGRADECIMENTOS}

A presente dissertação foi um grande marco na minha vida, no trajeto de sua elaboração fiz amizades do mundo inteiro, parceiros de negócios, aprendi muito e me inspirei com projetos admiráveis. Foram tantos os que me ajudaram a chegar até aqui que com certeza, esquecerei de agradecer alguém, então já agradeço de antemão todos os que contribuíram de alguma forma para o desenvolvimento deste estudo.

Aos meus pais Fernando e Maria Amélia, e irmãos, Paulo e Giovanna, por sempre estarem do meu lado me apoiando de todas as formas possíveis. Para minha outra enorme família, obrigada por sempre me ampararem nos bons e maus momentos de cansaço e alegrias desta dissertação.

À minha orientadora, professora Graziella Comini, pela dedicação, apoio e importantes contribuições, sem as quais eu não teria avançado no meu trabalho.

Não posso esquecer também de Fernanda Figueiredo por sempre me acompanhar e encorajar à prestar o exame para este mestrado profissional.

Aos meus sócios Carlos Eduardo e Guilherme, por enfrentarem comigo esta jornada e "tourearam" o enorme desafio que vivenciamos todos os dias ao gerir uma startup. Também agradeço ao Pedro, por me acompanhar no início das grandes aventuras da jornada empreendedora, bem como atuar na revisão prévia deste trabalho.

Ao professor Martinho Isnard Ribeiro de Almeida, pelas preciosas contribuições para esta dissertação, e ao João Paulo Bittencourt, por ter me apoiado em todo o trajeto desta pesquisa.

Um dos melhores frutos deste mestrado, com certeza são os bons amigos, por isso gostaria de manifestar gratidão para Marina, Edson, Daniel, Renata, Felipe, Pedro e Carlos, pelas boas conversas, reflexões na "van", risadas, e companheirismo, frequentar as aulas ficou muito melhor ao lado de vocês.

Agradeço também aos entrevistados para esta pesquisa pela doação de tempo, atenção e dedicação para ajudar no decorrer deste estudo. Em especial a Renata Urbano que colaborou para alcançar muitos dos objetivos e dificuldade da coleta de dados desta pesquisa. 
Seja a mudança que você quer ver no mundo.

Mahatma Gandhi 


\section{RESUMO}

Com o advento da internet, surgem no campo da filantropia plataformas digitais que utilizam o poder de mobilização de indivíduos da web 2.0 para apoiar financeiramente projetos socioambientais. Esta dissertação tem por base as experiências da startup Eventos do Bem, que utiliza o método de angariação online Peer-to- Peer (P2P). A abordagem digital do método de captação de recursos $\mathrm{P} 2 \mathrm{P}$ consiste na elaboração de campanhas promovidas por indivíduos online os quais podem utilizar seus eventos pessoais prol de uma causa social como aniversários, casamentos entre outros - para mobilizar sua rede de contatos propondo que seus conhecidos doem para sua campanha ao invés de os presentearem no aniversário. As experiências na realização de campanhas digitais em prol de organizações sociais no referido empreendimento, elucubraram problemas relativos à performance financeira das campanhas. Logo, esta pesquisa foi realizada com o objetivo de propor diretrizes e práticas que potencializem o sucesso deste tipo de arrecadação online. Visto ser um modelo aplicado de forma pioneira no país, como metodologia, optou-se pela estratégia de estudos de caso múltiplos com base em YIN (1994) na qual, em conjunto com o estudo da startup Eventos do Bem, selecionou-se a plataforma estadunidense Charity:Water, referência em angariação P2P. Como unidades de análise, foram abordadas as campanhas de angariação realizadas em ambas as plataformas, focando na categoria de campanhas de aniversário. Logo, o trajeto desta pesquisa delineou-se nas fases: (a) análise da experiência da startup Eventos do Bem, em paralelo com a leitura do referencial teórico pertinente; (b) pesquisa e seleção da plataforma Charity:Water; (c) estudo e realização de 46 entrevistas, compondose em 6 entrevistas com funcionários do Charity:Water e 40 efetivadas com criadores de campanhas de aniversário em ambas as plataformas; (d) análise de fatores e práticas influenciadoras das campanhas promovidas nos casos abordados; (e) estudo cross- case e análise dos resultados obtidos. Como resultado da pesquisa, foi delineado um procedimento de boas práticas para potencializar a performance das campanhas digitais, destacando-se ações referentes à interação individual do criador da campanha com toda a sua rede de contatos, a persistência no pedido e a realização de um discurso do pedido de doação com qualidade, isto é, que apresente argumentos para persuadir doadores mais emocionais como também os mais racionais e lógicos. Desta forma, o estudo contribuiu para expandir o debate de captação de recursos online e aponta inovações da técnica P2P no que tange à mecânica do processo de decisão para doar e demonstra que a técnica pode fornecer resultados que vão além da angariação de recursos, estimulando maior engajamento social dos participantes.

Palavras-Chave: Captação de recursos financeiros, E-filantropia, Captação de recursos online, Captação de Recursos Peer-to-Peer. 


\begin{abstract}
ABSTRAT
With the advent of the Internet, philanthropy is emerging in digital platforms that use the mobilization power of web 2.0 individuals to financially support social and environmental projects. This dissertation is based on the experiences of the startup Eventos do Bem, which uses the Peer-to-Peer (P2P) online raising method. The digital approach of the $\mathrm{P} 2 \mathrm{P}$ method of fundraising consists of the elaboration of campaigns promoted by individuals online who can use their personal events for a social cause - such as anniversaries, weddings and others - to mobilize their network of contacts by proposing that their acquaintances ache for their campaign instead of giving them on their birthday. The experiences in the accomplishment of digital campaigns in favor of social organizations in the mentioned enterprise, they have presented problems related to the financial performance of the campaigns. Therefore, this research was carried out with the objective of proposing guidelines and practices that will enhance the success of this type of online collection. As a model pioneered in the country, as a methodology, we chose the strategy of multiple case studies based on YIN (1994) in which, together with the study of the startup Eventos do Bem, we selected the platform American Charity: Water, reference in P2P fundraising. As units of analysis, the campaigns of raising were carried out in both platforms, focusing on the category of birthday campaigns.Therefore, the study's path was delineated in the phases: (a) analysis of the startup experience of the Good Events, in parallel with the reading of the relevant theoretical reference; (B) research and selection of the Charity: Water platform; (C) study and performance of 46 interviews, comprising 6 interviews with Charity: Water employees and 40 interviews with fundraisers on both platforms; (D) analysis of factors and practices influencing the campaigns promoted in the cases addressed; (E) cross-case study and analysis of the results obtained. As a result, a procedure of good practices was designed to potentiate fundraising $\mathrm{P} 2 \mathrm{P}$ performance, highlighting actions regarding the individual interaction of the campaigner with his entire network of contacts, a persistence without request and realization of a speech of the Request Of giving with quality, is, and presents arguments to persuade donors more emotional as also the most rational and logical. In this way, the study contributed to expand the online fundraising debate and points out innovations of the $\mathrm{P} 2 \mathrm{P}$ technique regarding the mechanics of the decision process to donate and demonstrates that the technique can provide results that go beyond fundraising, Stimulating greater social engagement of participants.
\end{abstract}

Palavras-Chave: Fundraising, E-philanthropy, Online fundraising, Peer-to-peer fundraising. 


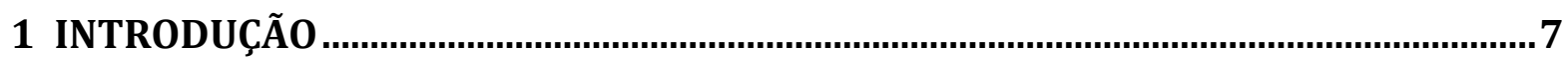

1.1 Relato da Experiência........................................................................................................

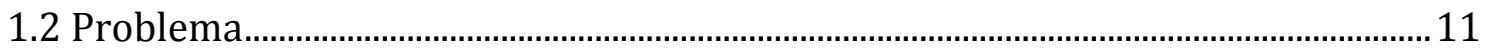

1.3 Questão de Pesquisa ..........................................................................................................13

1.4 Justificativa e Contribuições.........................................................................................13

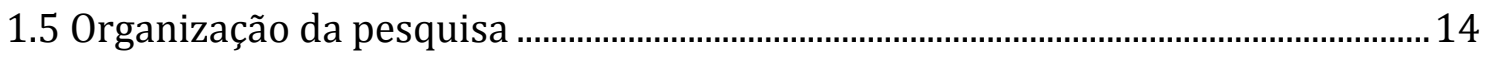

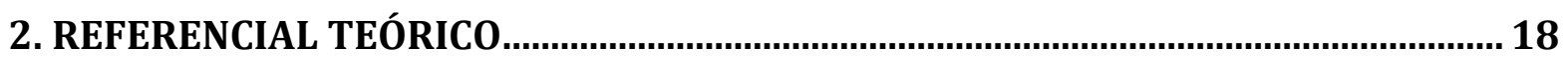

2.1 A Web 2.0 e a "Revolução da e-filantropia" ...............................................................18

2.2 A captação de recursos online.........................................................................................22

2.3 A captação na web 2.0: novos desafios e oportunidades para as OSCs.................46

2.4 O P2P ou o friendraising na web 2.0........................................................................5

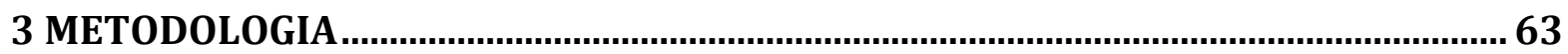

3.1 Pesquisa de Mestrado Profissional em Empreendedorismo ...................................63

3.2 Caracterização da Pesquisa ..........................................................................................6

3.3 Estratégia de Pesquisa: 0 estudo de caso ......................................................................65

3.4 Questão de estudo e proposições.....................................................................................66

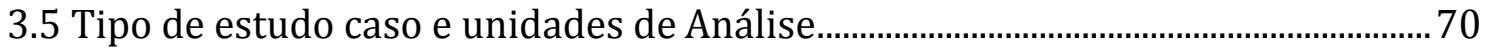

3.6 Modelo de pesquisa............................................................................................................

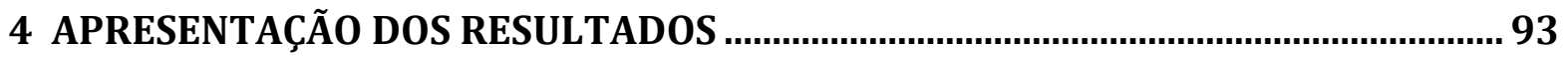

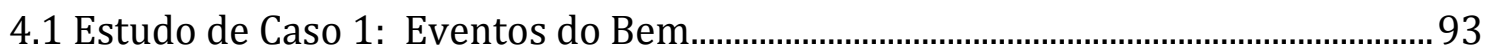

4.2 Estudo de caso 2: Charity:Water …………………………......................................... 113

4.3 A plataforma Charity:Water …………………………………………………………..... 120

5 ANÁLISE E DISCUSSÃo DOS RESULTADOS........................................................143

5.1 Apresentação do quadro de análise das campanhas P2P......................................143

5.2 Análise do Caso 1: A plataforma Eventos do Bem ................................................. 146

5.3 Análise do Caso 2: A Plataforma Charity:Water ....................................................... 159

5.4 Análise cross-case dos casos Eventos do Bem e Charity:Water ............................ 171

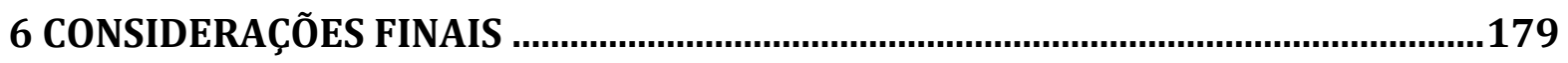

6.1 Síntese e resposta à questão de pesquisa.................................................................. 179

6.2 Limitação de pesquisa e agenda para trabalhos futuros ........................................ 187

7.REFERÊNCIAS............................................................................................190

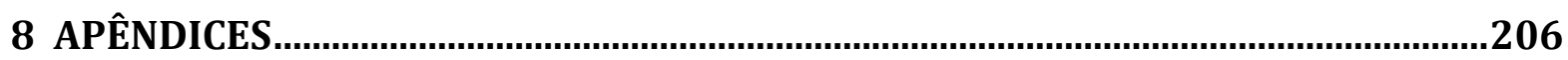

8.1 Apêndice - Roteiro de Entrevistas Organizadores das Campanhas EVB .....206

8.2 Apêndice - Roteiro de Entrevistas: Organizadores das Campanhas CW......208

8.3 Apêndice - Roteiro de entrevistas com os funcionários do CW .......................210 


\section{LISTA DE ABREVIATURAS E SIGLAS}

AFESU: Associação Feminina de Estudos Sociais e Universitários

CEO: Chief Executive Office

CW: Charity: Water

EVB: Eventos do Bem

EUA: Estados Unidos da América

P2P: Peer to Peer

OSC: Organização da Sociedade Civil

SGN: Social Good Network

SWOT: Strenghts (Forças), Weaknesses (Fraquezas), Opportunities (Oportunidades),

Threats (Ameaças)

TM: Tiquete-médio

USP: Universidade de São Paulo 


\section{LISTA DE QUADROS}

Quadro 1- Aspectos da Filantropia tradicional X E-filantropia.......................................29

Quadro 2 - Relação de objetivos e métodos da pesquisa....................................................77

Quadro 3 - Entrevistas e documentos do Caso 1: Eventos do Bem...................................85

Quadro 4 - Entrevistas e documentos do Caso 2: Charity: Water.......................................86

Quadro 5 - Entrevistas com funcionários da Charity: Water...........................................87

Quadro 6 - Eventos do Bem: práticas de divulgação de campanha dos organizadores.....106

Quadro 7- Charity:Water práticas de mobilização das campanhas..................................137

Quadro 8 - Avaliação da personalização da página de campanha online...........................145

Quadro 9 - Avaliação da interação entre organizador e sua rede.....................................145

Quadro 10 - Avaliação do discurso do pedido...............................................................145

Quadro 11 - Eventos do Bem: análise das ações dos organizadores...............................157

Quadro 12 - Charity: Water : Classificação das práticas dos organizadores.....................169 


\section{LISTA DE FIGURAS}

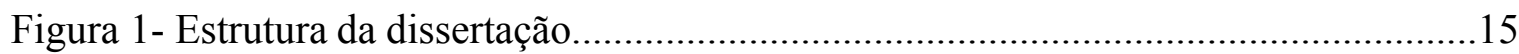

Figura 2 - Fatores influenciadores do processo decisivo de doar...................................27

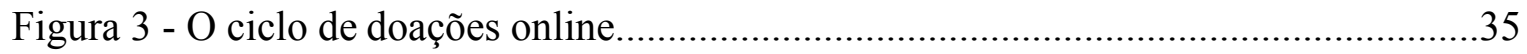

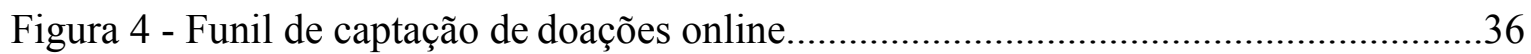

Figura 5 - Comparações da mecânica do crowdfunding x captação de recursos P2P.......53

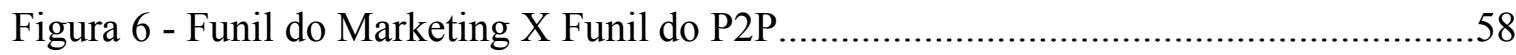

Figura 7 - Ciclo da aprendizagem experiencial de Kolb...............................................64

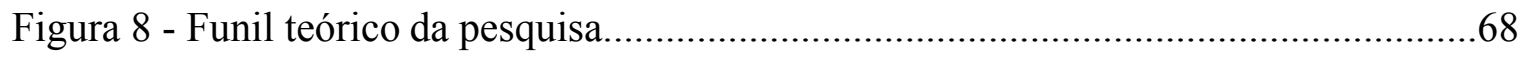

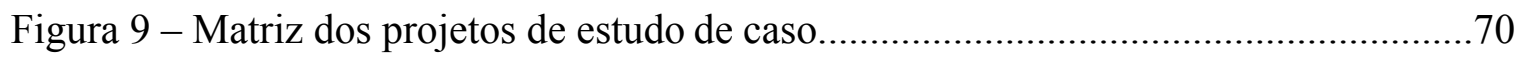

Figura 10: Modelo de proposições da pesquisa............................................................. 72

Figura 11- Estrutura de coleta e análise dos estudos de caso múltiplos desta dissertação..76

Figura 12 - Eventos do Bem: Fluxo do organizador da campanha..................................97

Figura 13 - Eventos do Bem: página da campanha de angariação....................................100

Figura 14 - Eventos do Bem: fluxo do doador da campanha...........................................104

Figura 15 - Versão de 2008 do website charitywater.org...............................................118

Figura 16 - Charity:Water: Fluxo do organizador da campanha...................................121

Figura 17 - Charity:Water : página da campanha de angariação....................................123

Figura 18 - Charity:Water: fluxo do doador da campanha...........................................132

Figura 19 - Charity:Water: página de doação da plataforma..........................................133

Figura 20 - Modelo final de influenciadores nas campanhas P2P online........................178

Figura 21- Boas práticas atuantes na jornada de angariação da campanha P2P online.....185 


\section{INTRODUÇÃO}

O advento da internet impulsionou uma grande revolução tecnológica, alterando fronteiras econômicas e a forma como as pessoas consomem, relacionam-se, atuam politicamente e transformam sua realidade social (CASTELLS, 1999). De consumidores e espectadores, os cidadãos da web 2.0 tornaram-se produtores, protagonizando o desenvolvimento de movimentos colaborativos digitais que atuam influenciando empresas, governos e organizações de impacto socioambiental (JENKINS, 2009). É a inteligência coletiva que toma forma, possibilitando a participação ativa de cada cidadão como agente de transformação de sua própria mudança de mundo.

Nesse novo contexto, surgem as plataformas de captação de recursos online com a proposta de fortalecer ações de indivíduos que querem promover suas próprias campanhas de arrecadação de doações para os projetos e causas sociais em que acreditam.

A técnica de angariação de recursos online mais famosa e atualmente mais conhecida no Brasil é o crowdfunding, um modelo de financiamento coletivo que busca concretizar projetos de produtos ou serviços por meio de usuários interessados na viabilização das ideias apresentadas.

Apesar de ser eficiente e recomendado para alguns casos, ao se tratar de captação de recursos online para organizações do terceiro setor, é notável que os casos mais bem sucedidos e conhecidos sejam os que utilizam a técnica denominada peer-to-peer, originando o desenvolvimento de diversas plataformas desse tipo de angariação digital (PAYNE et al. 2012).

As plataformas online P2P são caracterizadas por utilizarem a estratégia de captação de recursos online de forma "descentralizada", ou seja, a organização social não capta diretamente os recursos, mas engaja e transforma sua rede de apoiadores em captadores, os quais, por meio da criação de campanhas pessoais, mobilizam suas redes de amigos e conhecidos a doarem em prol da instituição.

Apesar de o fenômeno de indivíduos arrecadarem para as instituições sociais não ser novo - ocorrendo em diversos eventos como vendas de convites para jantares beneficentes, entre outros - a utilização da técnica no ambiente online é recente e está 
resultando em inúmeras abordagens inovadoras de captação de recursos.

O desenvolvimento das plataformas digitais peer-to-peer possibilitou que milhões de pessoas utilizassem eventos de sua vida e trocassem seus presentes de aniversário, de casamento por doações em prol de organizações sociais; motivou grupos de ciclistas, times de corrida, celebridades e empresas a criarem suas próprias campanhas e gincanas de angariação digital. Em suma, criou-se um modelo colaborativo de captação de recursos pelo qual pessoas de qualquer parte do mundo podem mobilizar angariações para as causas em que acreditam, abrindo a possibilidade de inovação na captação de recursos para Organizações da Sociedade Civil (OSCs).

O resultado consistiu em campanhas com temas inusitados, criativas, lúdicas, que envolveram seus apoiadores e inauguraram novos canais para as organizações sociais se engajarem e adquirirem novos apoiadores.

De acordo com estudos das mais conhecidas agências de captação de recursos online, mais do que o crowdfunding - no qual a própria organização social cria sua campanha online e pede doações para sua rede - o peer-to-peer é a técnica mais sustentável em longo prazo para as OSCs, visto que as campanhas pessoais permitem ativar novas redes de apoiadores, dos amigos e conhecidos das pessoas que organizaram as campanhas, permitindo a expansão para redes antes inacessíveis diretamente pela organização social, portanto chegando a montantes financeiros maiores (BRAITERMAN et al., 2016).

Esse potencial será mais bem aprofundado nesta pesquisa, que abordará como base a experiência da plataforma Eventos do Bem, pioneira em captação de recursos P2P no Brasil, em que a autora atua como empreendedora.

\subsection{Relato da Experiência}

A startup Eventos do Bem nasceu de um problema real vivenciado nos anos de experiência profissional desta autora, na Organização da Sociedade Civil, AFESU (Associação Feminina de Estudos Sociais e Universitários) ${ }^{1}$.

\footnotetext{
${ }^{1}$ A AFESU é uma associação filantrópica sem fins lucrativos fundadada em 1963 com a missão de capacitar profissionalmente e fornecer apoio escolar para mulheres, jovens e crianças moradores de periferia.
} 
Nos anos em que atuou na AFESU, era recorrente a busca pela sustentabilidade financeira; em vista disso, a área de captação de recursos realizou diversas ações e reuniões estratégicas tendo em vista diversificar e fazer crescer a base de doadores da OSC. Analisando a atuação online da entidade, verificou-se que sua presença na web era incipiente e, apesar de haver um sistema de pagamentos para doações online, a angariação de donativos no ambiente digital era praticamente nula.

Logo, uma das diretrizes identificadas para a atuação em novas frentes e ativação de doadores foi o desenvolvimento de um plano de captação de recursos online com o intuito de abrir novos canais de angariação, atingir novo público de doadores, adquirir novos parceiros, além de aproximar mais a rede dos apoiadores da OSC.

As ações tomadas resultaram no desenvolvimento de novos websites focados na captação de recursos e envolvimento de apoiadores para as quatro unidades da entidade; criação de vídeos institucionais; presença ativa e frequente nas mídias sociais da organização; foco na transparência da aplicação dos recursos por meio de relatórios financeiros publicados no website; investimento em e-mail marketing para atualização dos apoiadores e, aproveitando a tradição da AFESU de realizar eventos beneficentes de grande porte - como jantares, recitais e orquestras - focou-se a maior divulgação nas mídias sociais, vendas de convites online e divulgação em jornais e revistas virtuais de grande acesso.

Como resultado, houve um aumento na arrecadação de fundos para a entidade; no entanto, permaneceu a pouca expressividade de doações online, além de não ter ocorrido uma diversificação da rede de doadores, atendo-se somente aos apoiadores já fidelizados. Mediante esta escassez de resultados, foi realizada a pesquisa de inovações existentes para a angariação de donativos digitais.

No levantamento de infomações a partir das principais revistas e portais de angariação de recursos destacaram-se como casos de sucesso as plataformas Peer-toPeer internacionais, entre as quais as mais famosas: CrowdRise, Cause Vox, Charity: Water, Classy e Everyday Hero.

Nessas plataformas, os simpatizantes das Organizações podem criar campanhas pessoais de angariação de recursos para as causas que apoiam; logo, eram divulgadas diversas de campanhas de aniversário pelas quais pessoas pediam doações em vez de presentes para seus amigos e familiares, grupos de corridas com pessoas participando em prol de organizações e outras abordagens criativas nas quais as pessoas ressignificavam 
eventos de suas vidas como motivo para mobilizarem seus conhecidos a apoiarem sua campanha de donativos.

Além da abordagem inovadora, as plataformas obtiveram enorme montante de angariação financeira e apresentaram outras vantagens para as OSCs participantes, como a ativação de uma nova rede de doadores para o projeto ajudado e engajamento de apoiadores. As OSCs participantes adquiriram, portanto, uma ferramenta para transformar seus doadores diretos em captadores de recursos que, utilizando-se de seus eventos do cotidiano, expandem a causa para seu círculo de amigos e familiares nas mídias sociais.

Esses resultados possibilitaram considerar o financiamento $\mathrm{P} 2 \mathrm{P}$ como uma abordagem a ser validada. Em 2014 foi realizado um teste-piloto no qual a AFESU contatou alguns apoiadores com a proposta de trocar seus presentes de aniversário por doações para os projetos da organização.

Nas campanhas promovidas, as pessoas ganharam uma página de sua campanha de aniversário no site da OSC, com vídeos e fotos da causa beneficiada e o organizador da campanha elaborava um texto no qual explicava o projeto social para seus amigos e familiares, pedindo 'doações-presente' para a causa. Um termômetro com uma meta de angariação também foi colocado e atualizado de forma manual.

O resultado foi positivo: as campanhas angariaram recursos, algumas superaram o montante pedido e, principalmente, ativou-se o canal de doações online da Organização chegando a pessoas que estavam fora da rede da OSC.

Com o aumento de interessados na nova proposta de campanhas de aniversários, casamentos entre outros, houve a necessidade de um sistema mais desenvolvido e automático, que possibilitasse que a ideia fosse replicada em maior escala.

Além disso, visto que o problema de sustentabilidade financeira é comum na maioria das OSCs brasileiras, notou-se a oportunidade de desenvolver e proporcionar a tecnologia do peer-to-peer online para outras organizações.

Segundo Figueiredo (2013), a partir de uma análise SWOT $^{2}$ realizada em 217

\footnotetext{
${ }^{2}$ SWOT é um acrónimo de Forças (Strengths), Fraquezas (Weaknesses), Oportunidades (Opportunities) e Ameaças (Threats).
} 
Instituições Filantrópicas do Brasil, a captação de recursos é um dos maiores problemas das organizações pesquisadas. Assim, a autora aponta a diversificação de canais de recursos e a inovação das abordagens de captação como estratégias importantes para viabilizar uma sustentabilidade financeira maior para as OSCs.

Portanto, com base no panorama nacional e na experiência profissional da autora desta pesquisa, foi desenhada e desenvolvida de maneira independente a startup Eventos do Bem o modelo de captação de recursos digital peer-to-peer (P2P).

A plataforma online Eventos do Bem tem a proposta de atuar como uma ferramenta passível de ser utilizada por diversas instituições, empresas, ativistas e empreendedores sociais que queiram transformar seus eventos cotidianos em motivadores de financiamento de projetos socioambientais.

Com o desenvolvimento da plataforma online, os empreendedores participaram de programas de aceleração e capacitação de startups da área de tecnologia aplicada a impacto social como o Boot Camp da Universidade de Santa Clara e o Laboratório Social Good Brasil 2015, experiências que possibilitaram a comprovação das hipóteses de negócio e estruturação financeira do empreendimento.

\subsection{Problema}

Com o lançamento da plataforma web, foram realizadas centenas de campanhas que validaram a hipótese da possibilidade de diversificação de doadores. Foi possível despertar doações de pessoas que, apesar de nunca terem ajudado a OSC apoiada, foram estimuladas pela proposta de homenagearem seus entes queridos em campanhas como a de um aniversário.

No decorrer das campanhas, obtiveram-se diferentes resultados, interações entre os usuários, necessidades de funcionalidades específicas e inovações nas campanhas provenientes da própria rede de internautas engajados, das quais se destacam:

(a) inovações no tema da campanha - pessoas que angariaram para comemorar e agradecer sua cura do câncer; o aniversário de primeiro ano do filho; lista de doações como presentes de casamento; empresas que 
motivaram campanhas de doação por meio de gincanas de engajamento corporativo;

(b) inovações na abordagem para a mobilização de doadores organizadores de campanhas prometeram pagar desafios como pular de asa-delta, fazer gravações cômicas em mídias sociais ou até que cozinhariam jantares para os maiores doadores da campanhas caso alcançassem a meta.

Muitas das campanhas mencionadas foram bem-sucedidas e chegaram a alcançar a meta proposta. Todavia, apesar da surpreendente criatividade e potencial de notabilidade de algumas delas, observou-se que seu sucesso não dependia somente de sua originalidade. Algumas das campanhas não chegaram a arrecadar muito, enquanto outras, baseadas no tema mais tradicional, os aniversários, foram extremamente bem-sucedidas, muitas vezes arrecadando montantes maiores.

Logo, os empreendedores se depararam com aspectos que exigiram uma análise maior da dinâmica das campanhas, nas quais se verificaram aparentes incongruências no comportamento das redes de potenciais apoiadores e dos próprios organizadores.

Muitas páginas de angariação geravam notabilidade e apresentavam centenas de acessos, compartilhamentos, comentários e mensagens de apoio nas redes sociais, mas, apesar da aprovação social de muitas pessoas, somente uma pequena parcela chegava a contribuir financeiramente. Em relação aos organizadores, verificou-se que muitos desconheciam a mecânica de angariação de recursos online, com exemplos de comentários de que esperavam receber espontaneamente doações para suas campanhas sem terem de ativar sua rede, usuários que não sabiam doar com o cartão de crédito, e outros que encontravam dificuldade para utilizarem as mídias sociais para divulgação.

Enquanto alguns organizadores de campanhas obtiveram grande sucesso de arrecadação, uma considerável porcentagem passava pela frustração com eles mesmos e com sua rede de conhecidos pelo fato de não terem arrecadado o montante pretendido, o que influenciava a experiência positiva que se pretendia gerar e o próprio sucesso da plataforma.

Os resultados e experiências obtidos geraram questões sobre quais fatores mais 
influenciam a efetividade desse tipo de campanha de financiamento coletivo. De que modo a plataforma, o perfil dos organizadores, os projetos beneficiados e doadores interferiam nesse processo.

Considerando-se que a plataforma atua como ferramenta de captação de recursos online para pessoas que não são profissionais da área, era preciso identificar os fatores necessários e, assim, elaborar uma metodologia acessível, que guiasse os organizadores das campanhas para que esses mobilizem sua rede de contatos de forma eficiente.

Devido à ferramenta de angariação peer-to-peer ser recente no contexto influenciadores e abordagens mais recomendadas para essa nova lógica de campanhas pessoais de angariação. Essa situação levou a ser formulada a questão desta pesquisa.

\subsection{Questão de Pesquisa}

Como aumentar a captação de recursos financeiros das campanhas de angariação $\mathrm{P} 2 \mathrm{P}$ online?

\subsubsection{Objetivos Específicos}

- $\quad$ identificar os fatores relevantes para o sucesso da angariação online P2P a partir de campanhas realizadas na plataforma Eventos do Bem;

- identificar fatores relevantes para o sucesso de campanhas de financiamento coletivo P2P numa plataforma-referência nesse tipo de captação de recursos;

- reconhecer padrões de sucesso e insucesso nas campanhas analisadas na plataforma brasileira e no caso internacional selecionado;

- estruturar ações que contribuam para o sucesso das campanhas nacionais de angariação peer-to-peer.

\subsection{Justificativa e Contribuições}

Em meio a uma sociedade fortemente influenciada pelas transformações do ambiente cibernético, a captação de recursos aplicada ao ambiente online é uma necessidade crescente e indispensável para a sustentabilidade financeira das 
Organizações Sociais que contam com a captação de doações de indivíduos (AUSTIN, 2001).

A disrupção de uma nova era de angariação e relacionamento com o doador digital (LEE, 2007) resultou em inúmeras inovações para a captação de recursos, desenvolvendo empresas, novos produtos mais conhecidas, considerada, portanto, uma das mais importantes e populares técnicas atuais para angariação de microdoações digitais para OSCs (WATER, 2010; HART; GREENFIELD; HAIJI, 2007).

Todavia, apesar de sua crescente participação no mercado, ao se investigar a abordagem acadêmica sobre o fenômeno, nota-se a escassez de pesquisas sobre a técnica de captação digital P2P.

Logo, além de sua relevância para o desenvolvimento da técnica, esta pesquisa visa ao enriquecimento do debate científico sobre o assunto, principalmente no âmbito de um estudo proveniente de um Programa de Mestrado Profissional em Empreendedorismo, que busca aliar o rigor científico acadêmico à aplicabilidade prática do mundo real.

Ademais, considerando a conjuntura de necessidade de OSCs brasileiras que possuem a captação de recursos como um de seus desafios majoritários (FIGUEIREDO, 2013), também pretende-se aprofundar as especificidades da técnica P2P, abordada de forma inédita pela plataforma Eventos do Bem em contexto nacional e, assim, contribuir para o desenvolvimento tanto acadêmico quanto prático da e-filantropia no país.

\subsection{Organização da pesquisa}

A estrutura desta dissertação, ilustrada na Figura 1, está dividida em 6 capítulos: (1) Introdução; (2) Referencial teórico; (3) Metodologia; (4) Apresentação e análise dos Estudos de Caso; (5) Análise cross-case e resultados. (6) Conclusão. 


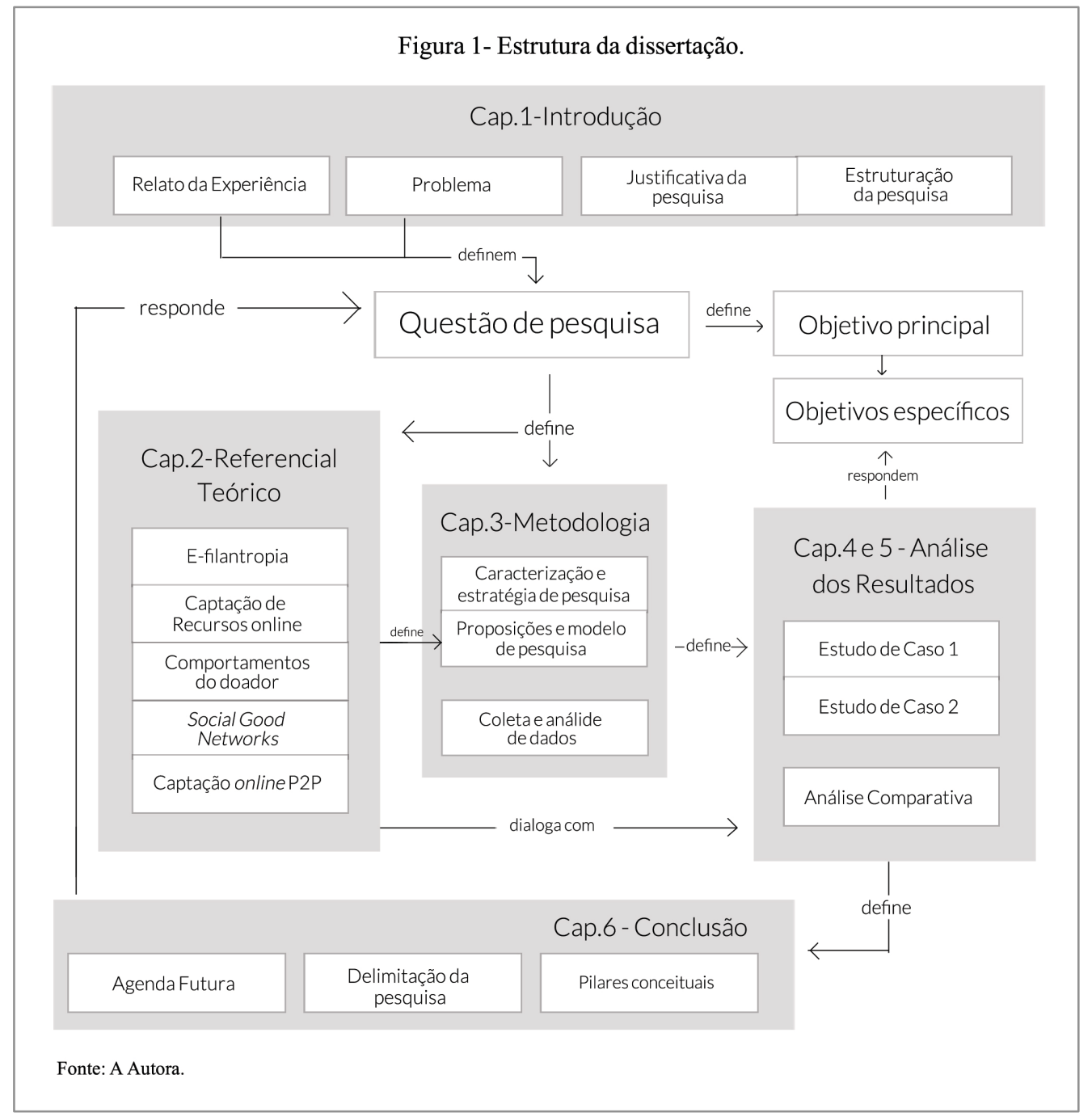

No primeiro Capítulo introduz-se o tema da pesquisa, contextualizando-o pelo relato de experiência sobre a vivência profissional da autora na área de captação de recursos da qual foi inspirada a startup digital Eventos do Bem. Após o relato, identificou-se o problema de pesquisa, emergente da experiência de realização de campanhas de angariação online $\mathrm{P} 2 \mathrm{P}$ e, por fim, as questões e objetivos geral e específicos que delinearam esta pesquisa.

Em seguida, o referencial teórico (Capítulo 2) que orientou as proposições e análise de pesquisa, no qual foram abordados os temas e conceitos principais sobre efilantropia, captação de recursos online, comportamentos do doador - identificando-se comportamentos específicos do doador da geração web -, as Social Good Networks e, por fim, os potenciais e práticas recomendadas de angariação online P2P identificados pela bibliografia.

Com base na questão de pesquisa de "como aumentar a captação de recursos 
financeiros das campanhas de angariação P2P online?", no Capítulo 3 traçaram-se os procedimentos metodológicos orientados pela estratégia de pesquisa de Estudo de Caso. Também se apresentaram as proposições de pesquisa e o modelo conceitual emergentes do referencial teórico abordado, assim como o modelo de coleta e análise de dados.

O Capítulo 4 foi orientado para se apresentarem os casos situando-os no contexto cultural e mercadológico de doação e e-filantropia nos respectivos países de localização, aspectos relacionados ao histórico dos empreendimentos, a jornada de experiência dos usuários nas plataformas e sua relação com as entrevistas efetuadas.

No Capítulo 5 apresenta-se a análise de cada caso, com os resultados num quadro analítico, possibilitando a interpretação e análise dos resultados. Após isso, com a análise cross-case dos dados obtidos, compararam-se padrões e pontos contrastantes entre as campanhas dos dois casos abordados.

Por fim, o Capítulo 6 consiste nas considerações finais a respeito dos dados obtidos. Nele são retomados os objetivos da pesquisa e explicitadas as respectivas conclusões resultando num modelo de procedimentos que apresenta as principais boas práticas influentes na performance da captação de recursos das campanhas de captação P2P online, respondendo assim à questão da pesquisa. Também são apresentadas as limitações e agenda futura de pesquisa 


\section{REFERENCIAL TEÓRICO}

No presente capítulo é apresentada a fundamentação teórica que orientou as proposições e análise desta dissertação de mestrado. Considerando-se a questão e os objetivos identificados, é abordada a discussão acerca dos seguintes temas: perspectiva e contexto de surgimento da e-filantropia, inovações, características e fatores influenciadores da captação de recursos online, o novo mercado intersetorial emergente, o mercado de angariação de microdoações digitais e, por fim, as características e influenciadores da captação de recursos de plataformas P2P.

\subsection{A Web 2.0 e a "Revolução da e-filantropia"}

Com a sua popularização em 1990, web 1.0 catalisou profundas transformações sociais e econômicas no mundo: além da interligação entre computadores numa rede global, as relações humanas tornaram-se globais, possibilitando a conexão de pessoas das mais diversas partes do mundo. Como resultado, estabeleceu-se uma sociedade com forte presença no meio digital, caracterizada pela cultura de mobilização e colaboração, a cibercultura (LEMOS; LÉVY, 2010).

Segundo Levy (2003), a cibercultura caracteriza-se pela inteligência coletiva, uma rede viva de indivíduos interconectados que, em tempo real, pode mobilizar competências e habilidades em prol de um objetivo comum. Em decorrência disso, o trabalho coletivo permitiu o desenvolvimento de redes, o intercâmbio de informações, novas formas de acesso, construção e compartilhamento de conhecimentos com o auxílio do computador.

Um dos importantes resultados desse fenômeno foi a expansão e progresso do universo da própria web, estabelecendo-se o que o teórico Tim O'Reilly (apud BRESSAN, 2007) define como web 2.0:

A Web 2.0 é a mudança para uma internet como plataforma, e um entendimento das regras para obter sucesso nesta nova plataforma. Entre outras, a regra mais importante é desenvolver aplicativos que aproveitem os efeitos de rede para se tornarem 
melhores quanto mais são usados pelas pessoas, aproveitando a inteligência coletiva de maneira a permitir modificações por outros usuários, criando efeitos de rede através de uma 'arquitetura participativa' e superando a metáfora de página da Web 1.0 para proporcionar ricas experiências aos usuários (O’REILLY apud BRESSAN, 2007, p. 4)

Dessa forma, sobrepondo a tecnologia dos sites da web 1.0, caracterizados como puramente informativos e unidirecionais, a nova geração da web possibilita o desenvolvimento de interfaces que descentralizam a produção de conteúdo da plataforma para cada usuário. Logo, o internauta deixa de ser mero espectador e consumidor de conteúdo para ser protagonista de mudança e produtor de informação.

Devido a isso a web 2.0 é marcada pela proliferação e popularidade de diversas mídias sociais online - como as plataformas Youtube, Facebook, Instagram e Twitter - cujo conteúdo é produzido e compartilhado pelos próprios indivíduos.

A influência dessa nova cultura gerou novas oportunidades e demandas de transformação da filantropia do século XXI, a mecânica de doação tradicional foi transformada, tornando-se fundamental a utilização dos potenciais da web 2.0 para gerar maior engajamento, mobilização e impacto social (AUSTIN, 2000). Esse novo tipo de atuação filantrópica online, demandada pelas organizações sociais, foi denominada como e-filantropia.

Definida paranáloga ao e-commerce nas empresas, alguns teóricos caracterizaram a e-filantropia pelo uso da internet para angariar doações financeiras e recrutar voluntários (AUSTIN, 2001), como o conjunto de estratégias direcionadas para o aprofundamento do relacionamento de doadores e captação de recursos (HART, 2002).

Não obstante, com o desenvolvimento de diversas iniciativas de filantropia online, atualmente o vocábulo veio sendo relacionado a múltiplas abordagens e palavras como as e-doações, e-fundraising, e-advocacy entre outros. 
Por isso, atualmente o conceito de e-filantropia abarca quaisquer atividades filantrópicas que utilizam técnicas de tecnologia para o cultivo e gerenciamento de relacionamento entre as organizações sociais e seus principais stakeholders (WATER, 2010; HART; GREENFIELD; HAIJI, 2007).

\subsubsection{O desenvolvimento de um novo mercado de donativos}

Sobre o histórico de desenvolvimento da e-filantropia, Lee e Hsieh (2010) afirmam que a angariação online remonta desde 1999 quando somente 1,2\% dos doadores doavam em ambiente digital e as organizações lutavam para se introduzir nesse novo meio.

No entanto, contextualizado pela tragédia do ataque terrorista ao World Trade Center, o cenário da e-filantropia mudou. Em menos de uma semana, foi arrecadado cerca de 1 milhão de dólares em donativos digitais, sendo considerado pelos teóricos um marco demonstrativo do potencial do ambiente online (BLAU, 2001; WALLACE, 2002; MILLER, 2002).

Como consequência, a partir de 2001 o mercado anual norte-americano de donativos digitais ganhou cada vez mais expressividade e tração. Entre 2001 e 2005, as doações online cresceram exponencialmente; as estatísticas do Instituto de E- filantropia avaliam o crescimento como de $1.700 \%$ nesse período com, em média, 4,5 bilhões doados online em 2005 (ANDRESEN, 2006).

Assim, o progresso da e-filantropia tem sido constante a cada ano e cresce em proporções maiores do que o mercado de donativos tradicional, o que segundo Lee (2007) denota o desenvolvimento disruptivo, uma abertura de um novo mercado de donativos e serviços de filantropia online.

Lee (2007) afirma que a internet possibilitou um universo de oportunidades de doação, configurando uma arquitetura inédita para ampliar canais de doadores e interagir com o público apoiador: é possível customizar e personalizar o tratamento aos doadores de uma forma massiva, automatizar operações que simplificam o processo de doação e, por fim, viabilizar a interatividade entre o apoiador e a plataforma em tempo real, de qualquer parte do mundo. 
Em conjunto com o teórico, Hart (2002) e Austin (2001) definiram a efilantropia como a mudança que irá revolucionar a captação de recursos e relacionamento com os doadores, caracterizando portanto a nova era de doações digitais como "Filantropia 2.0" ou a "revolução da e-filantropia".

\subsubsection{Inovações e potenciais trazidos pela e-filantropia}

Entre os potenciais da utilização das características interativas da web 2.0 para as organizações sociais, são identificados pelos estudos acadêmicos as características a seguir.

\section{(a) Acessibilidade}

Os autores destacam a democratização do meio digital, possibilitando que organizações de qualquer porte estejam presentes e desfrutem dos benefícios da internet, configurando um aumento de competitividade por doações (O'ROURKE; BALDWIN, 2004), o acesso a informações em qualquer horário e dia da semana, independente da localização dos usuários (CAROLL, 2003); a facilidade de adaptação e rápida resposta para a mobilização de campanhas digitais advindas de situações de desastres ambientais, políticos ou sociais. (NETWORK FOR GOOD, 2014; BLAU, 2001; WALACE, 2007).

\section{(b) Informação e transparência}

As plataformas das organizações sociais têm a possibilidade de educar doadores sobre sua causa, inspirarem um comportamento mais pró-social em sua rede de contatos, potencializar e abrirem novos canais captação de recursos (BHATTARCHARYA; BOLTON, 2000; SARGEANT; JAY, 2004; CUGELMAN; THELWALL; DAWES, 2011). Além disso, por meio de mídias online, as organizações podem informar a seus apoiadores o destino das doações e o impacto gerado por seu investimento, comprovando o valor social gerado ao informar o impacto proporcionado pelo apoio de seus doadores (PORTER; KARMER, 2002; BONBRIGHT, 2007). 


\section{(c) Interatividade}

O ambiente online pode agregar valor ao empoderar indivíduos a agirem em prol de uma causa social. O conceito de empoderamento pode oferecer oportunidades para o voluntariado digital, campanhas de angariação, advocacy entre outros (SARGEANT; JAY, 2004; BRUCE, 1994; BURNETT, 2002).

Ademais, a web possibilita a construção de comunidades online resultando em maior engajamento e envolvimento de apoiadores (LEE, 2007; HART, 2002; COYLE; THORSON, 2001; VAN NOORT et al., 2012; CHUNG; ZHAO, 2006).

\section{(d) Captação de recursos}

$\mathrm{Na}$ e-filantropia, a captação de recursos virou uma prática coletiva, construída com base no cultivo de comunidades de doadores online. Dessa forma, mais do que a angariação de recursos financeiros, o propósito da captação de recursos consiste na mobilização de doadores (KLEIN, 2007), construindo uma comunidade viva que garantirá a sustentabilidade da OSC em longo prazo. Um de seus resultados consiste no aumento da regularidade das doações e fidelização de apoiadores, além da abertura e ativação de novas redes de relacionamento (SARGEANT; JANY, 2004; HART, 2000). A utilização de ferramentas online para a captação de recursos também proporciona a diminuição do custo de aquisição de doadores, visto que muitas das ferramentas - como sistemas de pagamento e e-mails - automatizam procedimentos, economizando gastos administrativos (NETWORK FOR GOOD, 2007).

Todavia, considerando as potencialidades e inovações da e-filantropia apontadas, segundo Sargeant (2001) e Burnett (1992), é importante observar que as inovações por si só não trazem os resultados: é necessário que as OSCs estudem e desenvolvam um plano de captação, com estratégias específicas para o ambiente online a fim de conseguir implementar a tecnologia de forma eficiente, o que será tratado a seguir.

\subsection{A captação de recursos online}


Conforme explica Clayton (2009), os estudos sobre captação de recursos são baseados na investigação sobre fatores determinantes do comportamento de doação para OSCs, visto que a compreensão desse processo possibilita entender a mecânica do ato de doar e, por fim, desenvolver e aprender técnicas e abordagens eficientes para a aumentar a eficiência da captação de recursos.

Dessa forma, como introdução nas práticas de angariaçã online, serão abordados os principais estudos do comportamento e motivadores do doador. Serão tratados, também, o desenvolvimento de fatores influenciadores e conceitos em estudos tanto provenientes do advento da web quanto anteriores ao período, visto que, guardadas as limitações de seu tempo, os estudos anteriores à era digital embasam e enriquecem a perspectiva e debate acadêmico sobre os motivadores do comportamento no ambiente online (LESKOVEC, 2008; HART, 2002; SARGEANT, 2007).

\subsubsection{Os comportamentos do doador}

O comportamento e motivos que influenciam o processo decisivo do doador foram abordados desde 1970 por estudos de diversas áreas científicas como Psicologia, Administração, Marketing e Sociologia.

Na literatura, o comportamento do doador é referido por meio de diversos vocábulos, como comportamento pró-social (BURNET; WOOD, 1988), ato de caridade (SARGEANT, 1999), comportamento cooperativo (BENDAPUDI et al., 1996) pagamentos voluntários (BORCK et al. , 2006), altruísmo (GUY; PATTON, 1989), altruísmo impuro, warm glow ${ }^{3}$ (ANDREONI, 1990), investimento social e filantropia (HARBAUGH, 1998; ILCHMAN; KATZ; QUEEN, 1998).

De acordo com Bajde (2006), a literatura sobre a cultura de doação, que analisa em específico o processo decisivo do doador, pode ser compreendida em

\footnotetext{
${ }^{3}$ Warm Glow é um termo cunhado por Andreoni que corresponde à alegria que o apoiador vivencia no ato de doação. Segundo o autor, a experiência deste sentimento justifica muitos atos de caridade, Andreoni caracteriza portanto o warm glow como um tipo de "altruísmo impuro", visto que os doadores ajudam somente por interesse próprio, isto é, para vivenciar tal alegria e sensação de bem resultante.
} 
duas fases: a primeira, iniciada no fim de 1980, é marcada pelo estudo de Guy e Patton (1989) e Burnett e Wood (1988); a fase seguinte, compreendida em meados de 1990, destaca a pesquisa de Bendapudi et al. (1996).

Logo, o primeiro modelo teórico do processo decisivo do doador foi apresentado por Guy e Patton (1989). Nele, os autores identificam como o principal motivador a percepção do indivíduo da necessidade de ajudar; assim, após perceber sua responsabilidade e analisar a possibilidade real de contribuição financeira, é tomada a decisão de doar ou não.

Após essa primeira abordagem, iniciou-se uma sucessão de estudos nos quais foram identificados outros fatores que influenciam o processo decisivo do doador.

Desses estudos destaca-se a pesquisa de Burnett e Wood (1988) a qual, partindo de um modelo conceitual no qual mapeiam os principais pontos influenciadores do comportamento do doador, os autores concluem que a doação é um tipo de comportamento proativo social, entendido como um ato intencional, voluntário e altruísta, podendo ser explicado por diversas causas como a empatia, cooperação, compartilhamento e sentimento cidadão.

Esse modelo foi expandido em 1996, quando Bendapudi et al. (1996) apresentaram um novo viés ao processo de decisão do doador, introduzindo conceitos e motivações que não necessariamente consistiam no altruísmo puro debatido pelas pesquisas anteriores.

Entre os pontos levantados, Bendapudi et al. (1996) identificaram dois tipos de doação que caracterizam o nível de engajamento do apoiador com a instituição ou causa, a token help ${ }^{4}$ que consiste numa doação de valor baixo e a serious help ${ }^{5}$, uma doação de valor relevante para o doador.

Ademais, surge a modalidade de "doação egoísta", na qual o indivíduo é motivado por razões de benefício próprio, como descargo de consciência, evitar

\footnotetext{
${ }^{4}$ Bendapudi et al. (1996) denominam como Token Help a doação financeira pontual e irrelevante para o orçamento do doador.

${ }^{5}$ Bendapudi et al. (1996) definem como Serious Help a doação financeira relevante para o orçamento do doador, demonstrando portanto maior comprometimento com a causa e OSC apoiada.
} 
situações embaraçosas, conseguir recompensas, melhorar a autoestima, entre outros.

Logo, a identificação de que as doações podem ter motivadores altruístas e egoístas possibilitou considerar fatores extrínsecos motivadores que propiciam e estimulam doações, levando os autores a considerarem a existência do "altruísmo estratégico".

O altruísmo estratégico introduziu a possibilidade e a importância de planejamento e procedimentos que as organizações poderiam realizar para estimular o processo decisivo de doação de forma positiva, introduzindo de modo inédito ferramentas do mercado corporativo, como o marketing, no debate sobre captação de recursos no terceiro setor.

Outros estudos foram realizados com base nas constatações de Bendapudi et al. (1996) aprofundando ainda mais o assunto, todavia, com a revolução dos sistemas de informação e as mudanças provenientes da cibercultura, foi visível um novo marco para as pesquisas da área, visto que nascera um novo tipo de doador com características específicas da e-filantropia, intitulado "o novo doador", isto é o doador que é proveniente da cibercultura (WAGNER, 2002).

\subsubsection{O doador da web 2.0}

Apesar da bibliografia sobre as características do doador online ser escassa, ela vem aumentando a cada ano devido à importância crescente que a efilantropia está ocupando na angariação de recursos das OSCs. Em vista disso, foram realizados alguns estudos sobre comportamento e motivações para entender o novo doador virtual.

No artigo "Good people: a work in progress", Clayton (2009) discorre sobre as mudanças relativas aos doadores online e tradicional; para isso, suas características são ilustradas em duas representações de tipos de doadores, personificadas nas doadoras "Doroth" e "Selina":

- Doroth é caracterizada pela figura do doador tradicional, faz doações em 
dinheiro, prefere contatos pelo correio e uma das grandes motivações de seu apoio são sentimentos de culpa ou pena dos beneficiados. O envolvimento de Doroth acaba no momento em que conclui a doação financeira; não quer, portanto, qualquer interação posterior com a causa apoiada e não faz questão de acompanhar o impacto de sua doação;

- Selina pertence à geração da web, prefere doar online por cartão de crédito, demora para confiar numa organização e prefere iniciar o apoio com atividades que a aproximem da realidade da OSC a fim de ver diretamente o impacto social gerado por sua ajuda. Geralmente seu apoio inicial não envolve doações financeiras, no entanto a probabilidade de envolvimento com as organizações que apoia é grande. Dessa forma, quando adquire confiança na OSC, efetiva diversas doações financeiras, mobiliza sua rede de contatos, além de realizar ações como voluntariado, advocacy entre outros.

Ao analisar esses dois tipos de doadores, pode-se perceber que Doroth é um doador mais "fácil" para os captadores de recursos e organizações sociais, pois realiza as doações financeiras com frequência e fidelidade, sem exigir muito retorno de sua doação. No entanto, Clayton (2009) observa que, apesar de os captadores de recursos estarem mais acostumados ao doador tradicional, com as transformações da cibercultura esse tipo de apoiador está acabando.

Em contrapartida, Selina apresenta barreiras iniciais para doar, como desconfiança da seriedade da organização, a necessidade de se envolver mais para ajudar financeiramente e a exigência de uma prestação de contas das doações que realiza. Todavia esse tipo de doador tem grande potencial de se engajar com as causas que escolhe. Esse envolvimento é multiplicador e tem impacto mais profundo, tendo em vista que esse doador torna-se um "evangelista da causa", divulgando-a para seu círculo de amizades nas mídias sociais em que atua (MILLER, 2009).

Essas novas características do doador web implicam uma mudança nos motivadores e comportamentos que incentivam o ato de doar online.

Nesse contexto, as proposições de Bendapudi et al. (1996) foram ampliadas por Sargeant e Woodliffe (2007), nas quais os autores identificam 
fatores motivadores de doações singulares desse novo tipo de doador por meio de um modelo teórico que mapeia todo o processo de doação e influenciadores desse doador.

Figura 2 - Fatores influenciadores do processo decisivo de doar.

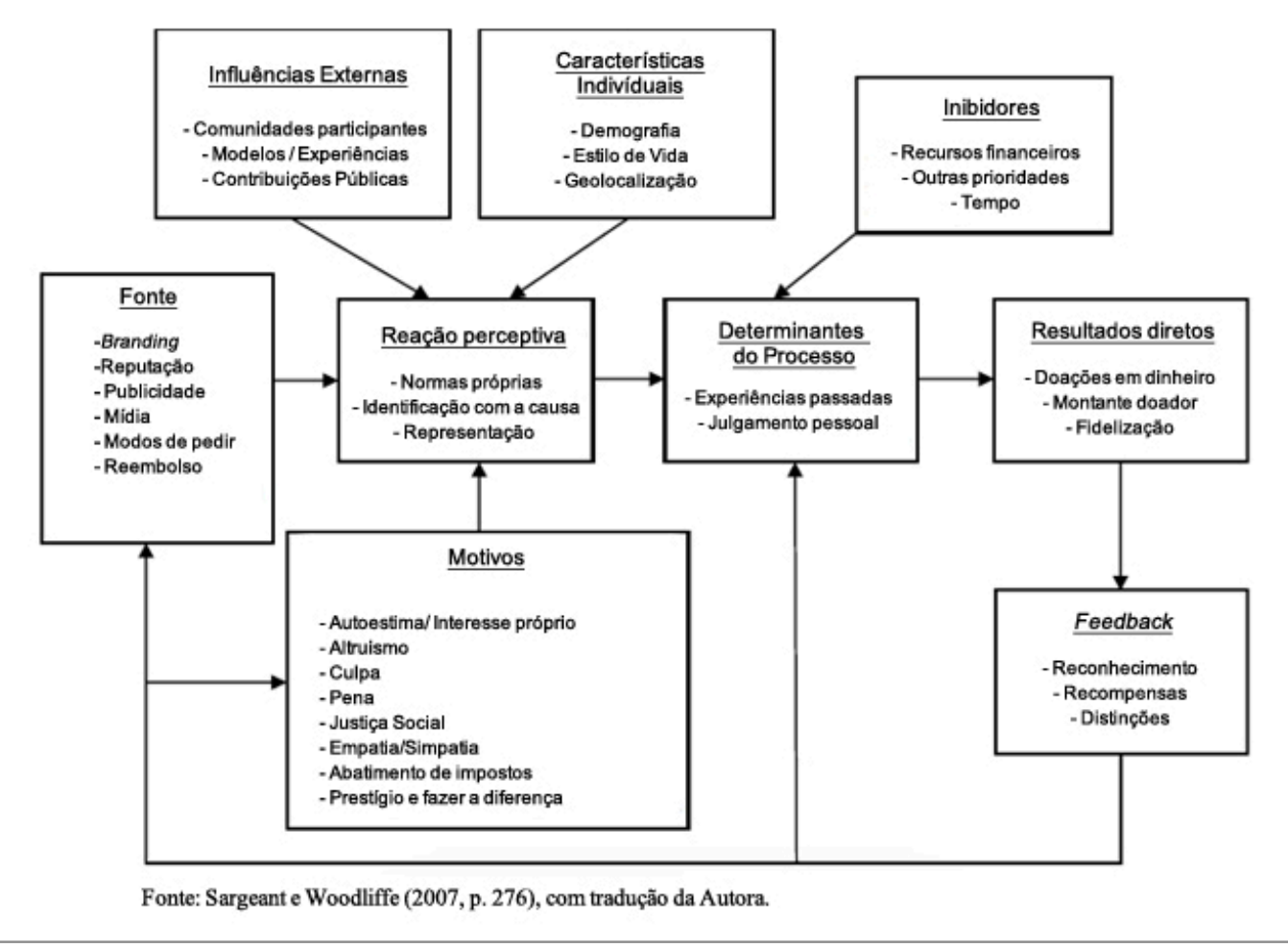

A Figura 2 apresentada por Sargeant e Woodliffe (2007) mostra uma visão holística sobre o processo decisivo do ato de doar, no qual foram identificados motivadores já apresentados em estudos prévios, como os sentimentos de altruísmo (GUY; PATTON, 1989), culpa, pena (AMOS, 1982; DAWSON, 1988) e simpatia (FULTZ et al., 1986). Além disso, ainda que Sargeant e Woodliffe (2007) apresentem motivadores de doações como um todo, em ambientes online e off-line, no modelo são identificados novos fatores provenientes da web 2.0, como influências do branding da instituição de caridade, a importância do retorno do impacto social, a influência das comunidades das quais o doador participa e a sensação de "fazer a diferença" apontados.

Cada um dos fatores é discutido e analisado por pesquisas e estudos de efilantropia, possibilitando uma visão mais aprofundada sobre o comportamento 
desse novo tipo de doador.

Segundo Miller (2009), um aspecto marcante proveniente da cibercultura é a valorização que os doadores dão para a participação em comunidades, logo suas ações são orientadas por suas crenças pessoais e as da rede social de que são pertencentes. Devido a isso, para esse tipo de doador, a doação também faz parte movimento que o indivíduo realiza como parte simbólica do pertencimento aos e identificação com seus grupos sociais.

Acerca da importância da prestação de contas das doações apresentada no modelo de Sargeant e Woodlife (2007), o relatório Next Generation Donors (2013) destaca que uma das características dos doadores virtuais se refere ao apreço dado ao retorno do impacto social apresentado. Essa é geração do "primeiro, o impacto" - impact first - isto é, querem primeiramente ver o impacto que podem gerar por meio da organização social, como condição para efetivarem a doação.

Isso se deve à desconfiança da geração de doadores web quanto à eficiência e veracidade das organizações sociais e outras instituições. Esses doadores querem ter certeza de seu impacto e verificar diretamente como as doações se tangibilizam em ajuda real por meio de voluntariados, advocacy e visitas às OSCs (MILLER, 2009; CLAYTON, 2009).

Por isso, o envolvimento pessoal nas causas é uma característica marcante, segundo Miller (2009) e Wagner (2002). Essa nova geração é marcada por grande interesse de protagonismo nas causas, são inquisitivos, exploradores e muito confiantes.

Analisando-se numa perspectiva mais ampla, esse comportamento faz parte do que autores como Jenkins (2009) e Castells (1999) identificam como cultura participativa. O potencial das comunidades virtuais na geração de conhecimento compartilhado, a participação ativa no desenvolvimento e divulgação de novos produtos, assim como os fluxos de conteúdo por meio de múltiplas plataformas de mídia são característicos dessa nova forma de atuar e se refletem no ato de doação: os doadores não querem mais ser apenas patrocinadores, mas participar ativamente das causas que apoiam. 
Logo, a geração de significado e sentimento de transformação do mundo é muito poderosa. Essa geração quer algo além de doar dinheiro; ela quer significado. Nesse sentido, Miller (2009, p.370) conclui que "não é exagero dizer que o captador de recursos está vendendo um pouco de significado de vida para essas pessoas em troca de doações".

Mas, para isso, os captadores de recursos têm de entender e oferecer oportunidades para as quais essa geração enxergue valor. Enquanto a maioria dos captadores sabe atuar com o modelo de doador tradicional, estes não têm ideia do que fazer com o novo doador. Sobre isso Miller (2009) destaca que o melhor motivador para essa geração é a inspiração.

No momento em que a organização consegue gerar significado, inspirando e fazendo parte da vida de seus apoiadores, a sustentabilidade financeira e efetivas doações ocorrem como consequência.

Esses doadores tendem a apoiar as OSCs em que acreditam, com quantias maiores do que a média e vão além, mobilizam tempo, contatos e têm o potencial de atuarem de forma mais proativa do que o doador mais tradicional. Como decorrência disso, Jillbert (2003) afirma que a natureza da relação com as organizações sociais mudou, devido ao impulsionador e mecânica de funcionamento da e-filantropia ser diferente do processo de doações tradicional, conforme é explicitado no Quadro 1.

Quadro 1: Aspectos da Filantropia tradicional X E-filantropia

\begin{tabular}{|c|c|c|}
\hline & Filantropia Tradicional & E-filantropia \\
\hline Quem & Pessoas de alto poder aquisitivo & Qualquer pessoa \\
\hline O que & Doando dinheiro & Investindo tempo, habilidades e dinheiro \\
\hline Como & Centralizada nas grandes Organizações & Foco em soluções e ferramentas \\
\hline Por que & Objetivos humanitários & Pessoas com as quais o doador se comunica \\
\hline Resultado & Beneficiários que o doador não conhece & . \\
\hline
\end{tabular}

Fonte: Jillbert (2003,p.9). Traduzido pela Autora. 
No modelo de Jillbert (2003), é notável que além das características do novo doador já mencionadas, o autor ressalta a característica do sujeito e o modo como as doações online são aplicadas. Em vez de poucas e substanciosas, centralizadas por filantropos de alto poder aquisitivo em grandes organizações, o meio online possibilita uma multiplicidade de microdoações que se somam a ponto de resultarem muitas vezes em montantes bem maiores do que as substanciosas doações dos grandes filantropos.

Além disso, como característica da geração Impact first mencionada, os novos doadores querem verificar diretamente o impacto social e estão mais interessados em ações que desenvolvam soluções e ferramentas para um impacto efetivo, do que medidas em longo prazo que não apresentem nenhum tipo de prova ou impacto social passível de ser verificado.

Esse novo tipo de comportamento, segundo Wagner (2002), gera uma transformação profunda na relação entre a organização e seus apoiadores pois permite caracterizar essa geração de, mais do que doadores - passivos e alheios ao impacto gerado - investidores sociais. Em consequência, métricas e indicadores de sucesso são cobrados das organizações e fazem parte do valor social requisitado em troca do investimento desses indivíduos.

\subsubsection{Fatores e boas práticas da captação de recursos online.}

Conforme explicitado no Capítulo 1.3 desta dissertação, a e-filantropia não consiste somente na simples ação de transação de donativos online, mas possui o objetivo de fortalecer o relacionamento com o doador dentro de uma estratégia de angariação de recursos - o friend-raising e fundraising (BURNETT, 1992). Essa mudança de paradigma suscitou novas pesquisas e teorias de captação de recursos, as quais se tornaram mais centradas em cultivar relações em longo prazo (friend-raising) entre organizações e doadores (BALABANIS; STABLES; PHILLIPS, 1997; BENNETT, 2005; MACMILLAN et al. 2005).

Nesse sentido, as OSCs que quiserem atuar com captação de recursos online de forma eficiente precisam criar uma estratégia integrada com as tecnologias digitais, desenvolvendo em conjunto um processo de experiências e 
gatilhos de interação com o doador, harmonizadas com as atividades e preferências desse público (HART; GREENFIELD; HAIJI, 2007). É importante frisar que a estratégia de e-filantropia não se apresenta como uma ruptura da técnica de captação tradicional, mas consiste em uma mistura de processos que ocorrem em ambiente online e off-line encadeadas para estimular maior interação e aprofundar relacionamentos com o doador.

No ciclo tradicional de doação, o doador é ativado por algum meio de comunicação e geralmente inicia o processo doando quantias menores. Com o decorrer do tempo, a OSC deve trabalhar a fim de provar para o apoiador sua eficiência e responsabilidade na gestão de sua doação. Caso essa percepção seja positiva do lado do apoiador, ocorre o aumento de confiança na OSC e é possível haver o estreitamento da relação, acarretando em outras ações de apoio mais substanciosas (TINDALL, 2007).

Esse modelo é cíclico e o contato deve ser cada vez mais aprofundado. Para isso os captadores de recursos devem utilizar várias estratégias para nutrir e fazer crescer o relacionamento com seus doadores, a fim de fidelizar e aproximálos cada vez mais da OSC (SARGEANT, 2001).

Na captação de recursos online, o modelo referido permanece; a diferença é que as etapas das fases de engajamento e relacionamento com o doador são pensadas considerando as ferramentas e potenciais da tecnologia web, gerando inovações e resultados distintos da captação de recursos tradicional (GOECKS et al. 2008).

Dessa forma, é possível considerar que a captação de recursos online depende de dois fatores:

(1) estrutura tecnológica apropriada de ferramentas e canais de relacionamento entre a OSC e sua rede de apoiadores;

(2) conhecimento e utilização adequada da organização social dos canais e ferramentas tecnológicas disponíveis no mercado.

\subsubsection{Estrutura tecnológica apropriada de ferramentas e canais de relacionamento entre a OSC e sua rede de apoiadores.}


A estrutura tecnológica das OSCs deve ser projetada tendo em vista mobilizar potenciais da web especialmente adequados para a construção e aprofundamento de um relacionamento entre as organizações e sua rede de apoiadores e, por fim, resultar na conversão de doadores digitais. Entre as características e ações necessárias para isso, SARGEANT et al. (2007) destacam as que seguem.

\section{a) Desenvolver uma estrutura adequada para receber doações}

A plataforma virtual deve ser fácil e permitir que em poucos cliques o usuário faça uma doação. A navegação pelas páginas deve ser fácil para o usuário e a página de doações deve ser destacada de forma relevante, ligada diretamente à página principal do website (SARGEANT et al., 2007).

Ao se falar em transações financeiras digitais, é importante efetivar a segurança de dados do doador na transação financeira digital e, além disso, estimular um ambiente digital que comunique segurança e sigilo de dados para o doador efetivar suas transações.

Dessa forma, são recomendados certificados de segurança de criptografia de dados (POLLACH, 2005; RYKER et al., 2005; MEINERT et al., 2006) e selos de privacidade (KIMERY: MCCORD, 2006) à mostra para o usuário, de modo que denotem a segurança na transação que será efetuada.

Em conjunto, os autores Pollach e Treiblmaier (2008) apontam a vantagem de uma política de segurança de dados em que a organização deixa claro que as informações dos dados pessoais ou do cartão de crédito ficarão em completo sigilo, garantindo a impossibilidade do acesso de terceiros.

\section{b) Apresentar página de transparência e prestação de contas}

A plataforma virtual deve indicar à seus usuários o destino de suas doações, é importante que a OSCs declarem total transparência e prestação de 
contas bem como a possibilidade de potenciais esclarecimentos quanto à doações passadas (SARGEANT et al., 2007). A prestação pode ocorrer por meio de vídeos, textos e histórias sobre o impacto, até relatórios financeiros demonstrando o destino da aplicação dos donativos (CHAO; SAXTON, 2014b).

Além disso, Johnston (1999) aponta o potencial da integração de e-mails automáticos com os sistemas de doações para possibilitar que as organizações agradeçam imediatamente ao doador enviando mídias e relatórios do público beneficiado.

\section{c) Seção que informe e eduque o usuário sobre a causa e organização social}

A causa deve ser comunicada para fazer com que o usuário aprenda mais sobre o problema que está sendo combatido e o impacto social que se quer gerar (SARGEANT et al., 2007). Assim, indica-se a existência e a possibilidade de download de relatórios e estudos sobre o assunto de forma dialogada com os textos e mídias educativas e, além disso, a integração com ferramentas de captura e remessa de e-mail marketing, com o envio constante de notícias da OSC (BOLES, 2013).

\section{d) Integração com ferramentas que permitam a interação com o usuário}

É necessário que a OSC utilize ferramentas virtuais para interagir com o usuário de alguma forma, por isso podem ser integradas à plataforma questões de quiz, chats, formulários de pesquisa, botões de compartilhamento em mídias sociais, blogs ou outros portais de atuação da OSC (HART, 2002).

\section{e) Empoderamento dos apoiadores}

É necessário viabilizar formas nas quais o apoiador se sinta protagonista de mudança e coopere de alguma forma para gerar impacto com a organização social. Isso pode ser viável por meio de ferramentas que possibilitem a assinatura de petições em prol de alguma causa socioambiental, páginas que estimulem e- 
mails para políticos, integrações com vendas online de bilhetes para eventos beneficentes e também pela integração de sistemas de microdoações - que serão explicadas no item 2.4.2 deste trabalho - como o crowdfunding e o fundraising peer-to-peer (KENT et al., 2003; LOVEJOY; SAXTON, 2012; MCNUTT; BOLAND, 1999; SARGEANT et al., 2007).

\section{f) Código de programação otimizado para mecanismos de busca e diversos aparelhos eletrônicos}

O desenvolvimento de plataformas na linguagem de código de programação deve possuir semântica especializada para que seja "encontrada" por seu público-alvo nos principais mecanismos de busca (BRANSTON; BUSH, 2010).

Além disso, considerando-se que o número de acessos por celular e outros dispositivos tem aumentado a cada ano (SINGH; MIDDLETON, 2010), os autores Mogus e Lacroix (2005) apontam a necessidade de websites responsivos, ou seja, com layouts projetados de forma que se adaptem a qualquer tamanho de tela, possibilitando o mesmo nível de acesso independente do dispositivo que o apoiador utilize.

\subsubsection{Conhecimento e utilização adequada da organização social dos canais e} ferramentas tecnológicas disponíveis no mercado.

Goecks et al. (2008) fazem uma análise da captação de recursos online em conjunto com as tecnologias e identificam três fases, que devem ser consideradas pelas OSCs, do "ciclo do fundraising digital": Associação, Doação e Feedback. 
Figura 3 - O ciclo de doações online

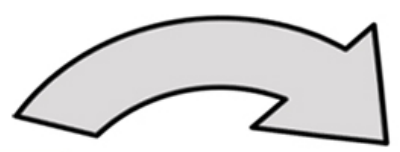

\section{Associação}

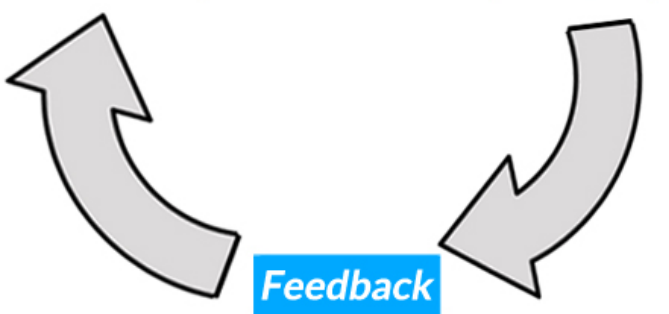

Fonte: Goecks et al. (2008, p. 694). Traduzido pela Autora.

A seguir será analisada cada fase apresentada, relacionando-a aos fatores e boas práticas de captação de recursos online identificados no referencial teórico sobre o tema.

\section{- Associação}

A fase de associação consiste na descoberta e identificação entre a organização e potenciais doadores. Durante essa fase, organizações sociais e outras empresas auxiliadoras promovem programas, serviços e objetivos de arrecadação financeira. Os teóricos destacam desta etapa as boas práticas descritas a seguir.

\section{a) Desenvolver um processo de captação de potenciais doadores}

Conforme afirma Hart (2001, p.23), o simples posicionamento de um botão de doação nos websites e em outros meios digitais não é o bastante para converter doadores, "não existem pessoas que estão na internet somente 
procurando organizações para doar”.

Assim, para captar novos doadores, em relação ao meio digital as organizações sociais devem desenvolver-se em campos como o Marketing, destacando-se o Marketing de Conteúdo (GROBMAN, 2000).

O marketing de conteúdo aplicado na web tem como premissa que, para o acesso de potenciais clientes, a empresa deve desenvolver conteúdo relevante referente a seu serviço que seja de comum interesse e informação aos potenciais clientes. Transpondo a teoria para organizações sociais, a dinâmica é similar: é necessária a produção de conteúdo que seja de interesse do público de doadores e potenciais doadores. Para tratar o processo de captação de novos doadores, foi desenvolvido um "funil de doações", ou seja, um processo de ações realizadas com o objetivo de atrair e converter doadores para a OSC (GARECHT, 2013).

O "funil de doações" (Figura 4) é orientado para estabelecer um procedimento contínuo em que as OSCs atraem novas redes de potenciais apoiadores a partir do desenvolvimento de um conteúdo relevante, que seja de interesse comum entre a entidade e seu público. No meio digital ele se inicia pela produção de blogs, podcasts e postagens em mídias sociais; logo após, é indicada alguma ferramenta de captura de e-mails, seguida pelo cultivo desses contatos por meio de um ciclo de e-mails e outras formas de estreitar a relação com o público, por fim, uma porcentagem interessa-se por virar doador.

Figura 4 - Funil de captação de doações online.

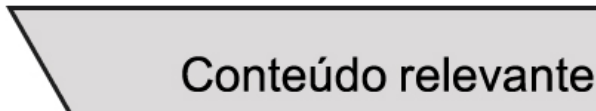

Captação de e-mails

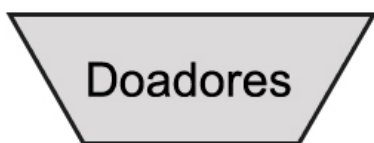

Fonte: A Autora 
Além disso, para aumentar a exposição e ativação de novas redes, é indicada a prestação de contas e relatórios de impacto social para criar um histórico de legitimidade da organização (MICHEL; RIEUNIER, 2012) e ações em conjunto com empresas parceiras (PRACEJUS; OLSEN, 2004; SAMU; WYMER, 2009).

Conforme afirma Miller (2002), o futuro do fundraising adaptado à nova geração web é deixar de ser considerado como um assunto externo e alheio à realidade das pessoas, para se tornar parte de suas vidas, atuando com assuntos nos quais elas estão interessadas.

\section{b) Conhecer a base existente de doadores}

De acordo com Sargeant (2001), o cultivo da base já existente de doadores para gerar aprofundamento de relações apresenta uma forma mais eficiente e com maior taxa de custo-benefício do que ativar um novo doador, pois as organizações sociais que propiciam experiências positivas com seus doadores são mais prováveis de obterem suas doações renovadas.

Em sua obra, em que ressalta a importância do relacionamento para a angariação de recursos, Burnett (1992) afirma que é necessário lidar com os doadores considerando suas individualidades, reconhecendo que cada doador é único e possui especificidades quanto ao histórico de doação, motivações para doar e, portanto, diferentes expectativas das OSCs.

Por isso é preciso que as organizações sociais conheçam e segmentem seus doadores, para cultivarem abordagens personalizadas e mais eficientes para cada tipo de apoiador (EWING; GOVEKAR; GOVEKAR; RISHI, 2002; PAYNE; HOLT, 2001).

Enquanto para a prática de captação tradicional, o estudo e tratamento personalizado dos apoiadores requer considerável força-tarefa da organização social, na web 2.0 essa tarefa é bastante simplificada por esse meio trazer o poder de desenvolver mensagens personalizadas a cada tipo de doador de forma massificada. 
Com a utilização de softwares apropriados para o estudo da base de doadores das OSCs, os autores destacam a combinação de estratégias de mercado como o Marketing de Relacionamento (BURNETT 2002; WEIR; HIBBERT, 2000) e o Marketing de Gerenciamento de Dados (BALABANIS; STABLES; PHILLIPS, 1997) como áreas auxiliadoras da captação de recursos.

Para auxiliar o marketing de relacionamento pelas OSCs, Polonsky e Sargeant (2007) destacam a utilização de CRMs - Customer Relationship Management. No caso das OSCs, os CRMs atuam como softwares de gerenciamento da base de doadores, segmentando seus contatos desde internos funcionários - até externos - como voluntários, doadores, parceiros, entre outros.

Conforme são implementadas as informações da base de doadores da OSC, é possível caracterizar os doadores em subgrupos de acordo com o valor doado, frequência de contato e especificidades de cada apoiador. Isso auxilia as organizações sociais a administrarem os contatos de forma harmonizada com disparos de e-mails e mensagens específicas para cada segmento definido. As funções incorporadas aos sistemas de CRM podem incluir contatos, atividades, análise oportunidades de doação, status de doadores, taxas de doadores desistentes, dados atualizados de campanhas de doação, relatórios de acessos das mídias da OSC e integração financeira (MOON; AZIZI, 2013).

Não obstante, independente do software utilizado, uma das chaves para o conhecimento da base de doadores é a prática de constante de alimentação desta base e aprendizado com o relacionamento que está sendo construído (SARGEANT, 2005). Com cada interação, algo novo pode ser aprendido sobre a pessoa e a organização, em termos de necessidades, preferências e costumes (PEPPERS; ROGERS, 1993). Quando as informações adquiridas são utilizadas apropriadamente, podem influenciar e adicionar valor à próxima interação, gerando uma experiência anterior mais positiva e gratificante que a anterior. Eventualmente isso agregará uma proposição de valor única para a organização, e significativa vantagem competitiva sobre outras entidades sem fins lucrativos (BOEDER; HOHN, 2004).

\section{c) Conhecer e utilizar os múltiplos canais de comunicação com o doador}


É indicado se utilizarem múltiplos canais de comunicação com o doador, de acordo com o seu estilo de vida e preferência de contato. No caso do doador $w e b$, as OSCs podem apropriar as mídias sociais como importante canal de atualização e engajamento de sua rede nas atividades, promoções e eventos desenvolvidos (ROTMAN et al., 2011).

No entanto, para uma comunicação mais personalizada a cada apoiador, Olsen et al. (2011) apontam a importância da utilização do mailing como um dos principais canais de comunicação e cultivo de relacionamento do doador digital. Para isso deve ser desenvolvido um plano de comunicação online no qual a organização informa que os apoiadores sobre notícias e novidades, e anuncia o status do impacto social gerado. Além disso, são importantes os e-mails de agradecimento às doações e outros apresentando novas formas de interação com a OSC - como eventos, oportunidades de voluntariado e corridas beneficentes - a fim de aproximar o relacionamento e continuar o ciclo.

Ademais, uma prática benéfica para efetivar uma boa experiência com a organização destacada por Sargeant (2001b) e Olsen et al. (2001) é dar a possibilidade de o doador do e-mail escolher como quer ser contatado e com que frequência, possibilitando uma relação personalizada e de respeito aos desejos do destinatário (GODIN, 1999).

\section{d) Utilizar as mídias digitais para o envolvimento de doadores para a causa}

A bibliografia sobre envolvimento de apoiadores para a causa identifica duas abordagens: o estímulo de sentimentos como pena e culpa (MERCHANT; FORD; SARGEANT, 2010) e o incentivo de atitudes de cooperação por meio da inspiração e projetos motivadores (MILLER, 2000; CLAYTON, 2009; FRASER; HIT; SAUER, 1998).

Segundo Smith e Berger (1996), essas abordagens dependem do tipo de envolvimento que a organização social espera do doador. No caso de doações motivadas por sentimentos negativos, elas são realizadas num curto pazo, normalmente por impulso, mas apresentam a contrapartida de não estimularem o 
envolvimento do doador. No caso das doações estimuladas por sentimentos positivos, estas requerem um trabalho de conversão do doador maior e em mais longo prazo, no entanto geram uma relação de envolvimento do apoiador à causa de forma mais profunda, possibilitandoo potencial maior de conversão de doações frequentes.

Clayton (2009) aponta que a forma mais eficiente de as organizações captarem novos apoiadores é por meio da inspiração. Para isso, o autor considera prejudicial que as OSCs desenvolvam propagandas que estimulem sensações de pena e culpa no público-alvo. Com Clayton (2009), os autores Fraser, Hit e Sauer (1998) verificaram que na maioria das vezes as doações motivadas por sentimentos de culpa e pena não são saudáveis para a sustentabilidade financeira da organização, pois, na maioria das vezes, o doador ajuda somente por descargo de consciência, sem desejar ter posteriormente mais contato com a causa.

Como característica de busca de maior significado para suas vidas, a geração da web quer se envolver mais com a organização social. Mas para isso querem ser motivados a entrarem num movimento que as inspire a viver um sentimento positivo (NEXT GENERATION DONORS, 2013; BAKER, 2005). Nesse sentido, existe uma mudança de paradigma importante: compaixão é pagar para ter um sentimento ruim levado embora, inspiração é comprar um sentimento positivo (CLAYTON, 2009).

Além do estímulo emocional, uma técnica bastante utilizada para a inspiração do público apoiador é a abordagem de contar histórias, o Storytelling, de forma que estimule a atenção e interesse dos ouvintes. O Storytelling exerce um papel importante no modo como as pessoas entendem e administram suas relações sociais, fazendo com que consumidores sintam a realidade pela interação entre símbolos e narrativas que lhe permitem "vivenciar o momento" (RICHERT, 2003). Conforme afirma Goodman (2006), as histórias são meios mais eficientes de gerar a persuasão e o engajamento do que os fatos puros.

Contar histórias tem grande potencial de empatia dos espectadores com a causa apoiada fazendo com que esses se envolvam emocionalmente na narrativa (BAKER, 2005; JOHNSTON, 2005). No caso das organizações sociais, o storytelling é especialmente interessante, pois a situação-problema, que dispara a 
narrativa é a própria causa da organização. À medida que a narrativa se desenvolve, é apresentado ao doador a oportunidade de agir e remediar a situação, para assim reduzir a tensão e balancear a estória (MERCHANT; FORD; SARGEANT, 2010).

Como pessoas doam para as causas com as quais sentem algum tipo de proximidade, o storytelling no ambiente da web - denominado digital storytelling - possui enorme potencial, pois é possível ser apresentado em diversas mídias como fotografias, videos e sons, sendo recente as experiências com óculos 3D que viabilizam a experiência de empatia ainda mais aproximada de se "sentir na pele do outro" (GENESKE, 2014).

\section{e) Construir uma comunidade}

Um dos grandes potenciais do ambiente online para OSCs consiste na criação de comunidades digitais capazes de unir pessoas de qualquer parte do mundo em prol de uma causa social comum.

Entre as estratégias para a construção de comunidades online já apontadas nesta dissertação - como a criação de conteúdo relevante - os estudos acadêmicos destacaram a providência de áreas em websites e outras plataformas que possibilitem que os membros possam: conversar e compartilhar suas idéias em chats e fóruns de discussão (HAGEL; ARMSTRONG, 1997); divulgar, por plugins de compartilhamento em mídias sociais ou e-cards (INGENHOFF; KOELLING, 2009), as causas que apoiam; atualizar constantemente os membros sobre as notícias da OSC por mailing ou alguma mídia online (SARGEANT, 2001); e apresentar as necessidades e oportunidades de envolvimento e ajuda dos membros para a causa (HON; GRUNIG, 1999; WATERS, 2009).

\section{- Doação}

Durante a fase de doação, os doadores tomam decisões relativas à escolha da OSC e valor do apoio financeiro. Devido a essa fase ser extremamente 
importante para a angariação de recursos para OSCs, a maioria das pesquisas acadêmicas concentram-se nela.

\section{a) Fazer o pedido}

O estudo de Andreoni e Rao (2011) aponta para as influências psicológicas que o pedido de doação pode acarretar nos receptores. No estudo, os autores defendem que as pessoas não evitam a doação, mas evitam ser chamadas para doar.

Assim, o pedido de forma direta é um importante componente para aumentar as doações, o que se coaduna com pesquisas que apontam os pedidos como uma forma de cultivar mais doadores e aumentar a frequência de doações (DEJONG; OOPIK, 1992; ANDREONI; RAO, 2011).

Wash e Lampe (2012) afirmam que, na web, a existência de pedidos explícitos para o usuário doar faz com que as OSCs aumentem a intenção de doação em 23\%. Em vista disso, são recomendados que os botões de doação estejam visíveis nas plataformas virtuais, com cores constrastantes ao fundo da plataforma online e que se apresentem de forma clara e com poucas etapas ou cliques para a doação ser efetivada.

\section{b) Contextualizar o pedido de forma propícia}

Sobre a contextualização do pedido, o storytelling e sua utilização na web, já explicitado, foi indicado como um importante componente para contextualizar e motivar o pedido de doações (MERCHANT: FORD; SARGEANT, 2010).

A pressão social proveniente do pedido e também foi apresentada como importante fator que influencia a doação (BEKKERS; WIEPKING, 2011; HARBAUGH, 1998; ANDREONI; PETRI, 2004) e apresenta-se muitas vezes por meio das comunidades web (NEXT GENERATION DONORS, 2013; CHEN et al., 2009). 
Nesse sentido, também é destacada a pressão do pedido de doação de amigos e conhecidos como importante canal de conversão de doadores. O pedido pessoal por meio de conhecidos é considerado um dos mais efetivos para a conversão de doações, sendo identificado nos estudos com o potencial de converter até $50 \%$ mais doadores do que o pedido massivo, impessoal (BRAITERMAN et al., 2015; LEIDER; MOBIUS; ROSENBLAT, 2009).

\section{c) Apresentar valores que sirvam de referência ao doador}

As pesquisas sobre captação de recursos afirmam que a presença de valores sugeridos nos formulários de pedidos tem impacto direto nos resultados financeiros (VERHAERT; VAN DEN POEL, 2011; SIMONSON; DROLET, 2004).

Além disso, é analisada a influência de diferentes montantes - valores mais altos ou mais baixos que o tíquete-médio de doação - no resultado da captação financeira. A bibliografia sobre esse assunto diverge nas práticas recomendadas: alguns teóricos apontam que pedir montantes menores incentiva mais doações (DEJONG; OOPIK, 1992; REINGEN, 1978); outros afirmam que, quanto maiores forem os valores sugeridos, maior será o montante angariado (FRASER; HIT; SAUER, 1998).

\section{- Fechando o ciclo: o feedback}

A fase do Feedback - o retorno do impacto social gerado - consiste em como uma OSC comunica e comprova o impacto social gerado pelas doações a seus stakeholders. Uma das características dos doadores digitais é a importância dada à resposta de suas doações. É essa resposta que aproximará os apoiadores e aprofundará o relacionamento com as organizações sociais, transmitindo sensação de confiança e legitimidade para elas e, assim, permitindo que o ciclo ocorra mais vezes (HART; GREENFIELD; HAIJI, 2007).

Em relação ao feedback online, a bibliografia clássica sobre o assunto, com Hon e Grunig (1999), Ledingham (2003) e Kelly (1998) - que guiaram os posteriores estudos sobre a área - aponta quatro estratégias de gestão eficiente 
das doações para aprofundar o relacionamento e a cumplicidade entre a organização e os apoiadores, a seguir descritas.

\section{a) Reciprocidade ou Compensações do doador}

A reciprocidade é expressa pelo mútuo cultivo de respeito pela expressão de gratidão entre a OSC e o doador. Pode ocorrer sob a forma de reconhecimento público

- por meio de certificados, eventos, entre outros - ou de forma privada com cartas de agradecimentos, e-mails entre outros.

Grunig e White (1992) consideram a reciprocidade como a base da responsabilidade social. Quando um público de apoiadores adota ações positivas como doações para sustentar a OSC, as entidades devem devolver de alguma forma o apoio a fim de manter o balanço social com o seu público.

Segundo Andreason e Kotler (2003), além do reconhecimento das entidades, existem outras recompensas pelo ato de doar. Elas podem ser materiais, como a redução do imposto de renda (LANKFORD; WYCOFF, 1991), ou imateriais, como o alívio de um sentimento de culpa, aumento da autoestima (AMOS 1982; DAWSON 1988), reconhecimento, prestígio social (HARBAUGH, 1998) e a felicidade recorrente após a própria doação - o warm glow (ANDREONE, 1990).

No caso das doações digitais, além das mencionadas, somam-se compensações como a geração de significado para os doadores que se envolvem nas causas sociais, a possibilidade de participarem de uma comunidade nova e também de aceitação social nas mídias e comunidades online de que participam (MILLER, 2009; GLAYTON, 2009; HART; GREENFIELD; JOHNSTON, 2005).

\section{b) Utilizar a doação de forma responsável}

Segundo Hung (2002), utilizar a doação de forma responsável significa que o dinheiro doado deve ser investido no exato propósito que motivou sua 
doação. Kelly (1998) reforça que os captadores de recursos e OSCs têm a obrigação ética de garantir que os fundos angariados sejam aplicados exatamente nos programas estipulados.

Os autores reafirmam que, caso essa confiança seja traída, principalmente no ambiente web, a divulgação viral é facilmente executada, manchando a imagem da organização social de forma irrecuperável, podendo levar desde a perda de enorme rede de doadores, até a falência da organização (HOPKINS, 2005).

\section{c) Prestação de contas e atividades}

As organizações podem demonstrar sua contabilidade ao providenciarem informações abertas e apuradas para o público doador.

Para Gordon, Knocke e Neely (2009) essa é uma das formas mais notáveis de diferenciar e legitimar eticamente uma OSC. No entanto, é atentado que uma decisão importante consiste em quais informações devem ser abertas ao público, de modo benéfico ao estreitamento das entidades sociais com os doadores.

Apesar de demonstrar fatores positivos como transparência e legitimidade da organização, a abertura da contabilidade das doações, pode levar os apoiadores a questionarem os gastos administrativos da OSC em relação ao montante que realmente é direcionado para a causa. Weisbrod e Dominguez (1986) definiram tal relação como o "preço de doar", ou seja, o cálculo de pagamento no percentual de cada doação que é direcionado para financiar os custos administrativos e, portanto, não vão diretamente para a causa social. Isso pode ser muitas vezes um inibidor de doações para as OSCs: os doadores questionam a eficiência de suas doações ao considerarem que uma porcentagem não vai diretamente para a causa social (WEISBROD; DOMINGUEZ, 1986; GORDON et al., 2009; JACOBS; MARUDAS, 2009).

Existe um risco, portanto, ao abrir essas informações, por isso o modo pelo qual a contabilidade financeira deve ser aberta é apontado como um caso a ser pensado pelos gestores das organizações sociais (ZHUANG; SAXTON; WU, 
2014).

\section{d) Nutrição da relação}

Esse é o momento em que a organização gera a publicidade de sua eficiência. As OSCs podem enviar notícias e relatórios anuais; os maiores doadores devem ser convidados para eventos, open-houses e, enquanto a relação se fortalece, os captadores de recursos podem enviar cartões escritos à mão em ocasiões especiais como aniversários (KELLY; LEWIS, 2001).

Além disso, Aknin et al. (2012) indicam que oferecer a possibilidade para os doadores se educarem sobre o impacto social que geraram possibilita seu envolvimento em doações posteriores.

\subsection{A captação na web 2.0: novos desafios e oportunidades para as OSCs.}

Ao analisar a estrutura tecnológica e a mecânica de boas práticas da efilantropia, é notável a complexidade e demanda do investimento numa estrutura apropriada de TI e de novos conhecimentos em áreas como marketing e tecnologia da Informação para as OSCs.

De acordo com Waters (2008), o advento da web não é a primeira vez que OSCs e captadores de recursos tiveram de se adaptar a novas tecnologias. No entanto, neste caso, chama a atenção para o fato da transformação ocorrer de forma bem mais acelerada do que o ritmo de desenvolvimento das técnicas de captação de recursos, apresentando um desafio inédito de capacitação constante e mais acelerada para as OSCs.

Sobre a indispensabilidade da prática e desenvolvimento da captação de recursos online pelas OSCs, James Austin alerta:

Não se engane: A revolução da e-filantropia está aqui para ficar, e irá transformar $\mathrm{o}$ ato de doar de uma forma tão profunda quanto a tecnologia está mudando o mercado. As organizações sociais que ignorarem a e-filantropia, logo terão de correr atrás e se reconciliar. Caso não o façam, estão 
arriscando perder o contato com seus doadores... e comprometerão a vitalidade do trabalho da organização (AUSTIN, 2001. Apud. KELOGG FOUNDATION, p.30, Tradução da Autora).

Apesar disso, a realidade de defasagem no desenvolvimento da efilantropia é ressaltada por diversas pesquisa e teóricos.

Ao analisarem os websites das organizações sociais, autores como Sargeant (2001), Taylor, Kent e White (2001), Kang e Norton (2004) apontam para a falta de utilização de recursos característicos da web para o engajamento do doador online, como ferramentas de interatividade e comunicação dialógica. A maioria dos sites analisados apresentaram funções meramente ornamentais, existindo somente para fornecer à organização uma presença digital, sem objetivos concretos de marketing e, portanto, sem a utilização dos recursos tecnológicos propícios para o desenvolvimento da e-filantropia.

O mesmo ocorre com mídias sociais, conforme Hackler e Saxton (2007), em relação ao Facebook, por exemplo. Apesar de o mercado de oportunidades para a captação de recursos ter crescido para OSCs, os dados demonstram que somente $3 \%$ das organizações cadastradas estão angariando pela mídia social (NTEN; M+R STRATEGIC SERVICE, 2012).

Dessa forma, é verificado que, apesar dos potenciais da web 2.0 para o desenvolvimento e otimização da captação de recursos, muitas das OSCs não estão capitalizando essas oportunidades.

Na pesquisa realizada com 10.500 OSCs pela empresa TechSoup Global (2012) indicou que $60 \%$ das organizações sociais se consideram pouco capacitadas para utilizarem com eficiência as ferramentas da web em prol da sua causa.

Bennet (2005) afirma que, apesar de reconhecerem a importância das tecnologias, a grande maioria das OSCs não tem conhecimento sobre como utilizar as ferramentas de modo eficiente, nem sobre como elaborar estratégias concretas que visem o desenvolvimento de sua missão.

Outros autores complementam, chamando a atenção para o fato de muitas 
organizações não dedicarem quase nada do orçamento para implementações tecnológicas (JOHNS HOPKINS, 2010) e, apesar de encorajarem inovações na área, não fornecem suporte para a realização delas (BOLES, 2013).

Em conjunto com a questão apontada, para comprovar a inexploração e potencial do mercado da e-filantropia, ao abordar o mercado britânico, Shen (2001) analisa 50\% das vendas do segundo setor ocorrem por e-commerce; em comparação, somente $2 \%$ do total de doações ocorrem online. O autor concluiu, então, que num país com a cultura de compra online bem desenvolvida, a razão para a pouca expressividade da e-filantropia deve-se ao mau aproveitamento do potencial da web pelo terceiro setor.

Em decorrência disso, diante do desafio e demanda das organizações de utilizarem a internet de forma eficiente e da inexploração do potencial do mercado de doações digitais, surgem empresas intermediárias que possibilitam que as organizações terceirizem alguns aspectos de sua cadeia de valor, introduzindo ferramentas profissionais de apoio à inovação e gerando novos canais de relacionamento e captação de doadores: as Social Good Networks.

\subsubsection{As Social Good Networks}

De acordo com Reis e Clohesly (2001), a tecnologia digital mudou o modelo tradicional da relação unidirecional doador-beneficiado, viabilizando um ambiente mais aberto, intersetorial, no qual filantropos e empresários trabalham juntos. Esse movimento fez com que investidores de venture capital e empreendedores identificassem a filantropia como um novo setor a ser explorado pelo e-commerce.

Os autores apontam o fenômeno pelo qual investidores e inovadores sociais estão levando para a filantropia modelos com base mercadológica que enfatizam a propriedade, a mensuração de resultados, a sustentabilidade financeira e os modelos de negócio com potencial de escalabilidade. Esses modelos definidos como Venture Philanthropy e empreendedorismo social estão expandindo as fronteiras da filantropia tradicional.

Num artigo, Gray (1998) descreve essas novas organizações e novos líderes: 
[...] irão moldar a caridade no próximo século [...]Até a linguagem que estes jovens líderes utilizam é diferente das gerações anteriores. Termos como ativista, trabalhador social, e líder comunitário foram substituídos por empreendedor social. Eles procuram novas formas de integrar OSCs, governo e empresas privadas para gerarem rápidas e quantificáveis melhorias para os problemas sociais (GRAY, 1998, p.1. Tradução da Autora).

Em consonância, Branston e Bush (2010) definem esses empreendimentos privados que atuam na e-filantropia como Social Good Networks (SGNs). A expressão Social Good Networks refere-se às plataformas web direcionadas a gerar impacto social por meio do uso de ferramentas de tecnologia e, dessa forma, ajudar organizações sociais oferecendo portais de arrecadação de recursos, de informação e relacionamento com apoiadores.

Apesar de serem recentes e de haver pouca pesquisa acadêmica sobre o assunto, o fenômeno das SGNs tem-se apresentado crescente (REIS, 1999). Num estudo apoiado pela Fundação Kelogg, Reis e Clohesy (2000) identificam e mapeiam algumas das mais famosas SGNs estadunidenses que atuam para auxiliar as organizações sociais em e-filantropia, nelas, os autores distinguem oito categorias: e-commerce, captação de recursos, serviços de auxílio à OSC e ao doador, informações e apurações de OSCs, serviços de voluntariado, advocacy e ações sociais, portais de eventos e leilões beneficentes, market-places de efilantropia. Elas estão descritas a seguir.

- E-commerce: surgem as plataformas que providenciam a conversão de uma porcentagem da venda de produtos online para as OSCs. Em alguns websites, os usuários que efetuam a compra podem escolher a organização social que desejam apoiar com um percentual doado pela empresa. As iniciativas que têm essa atividade como principal estabelecem parcerias com empresas que atuam no e-commerce para converter um percentual das vendas delas e, paralelamente, possuem um banco de organizações sociais que pagam um percentual do valor angariado para a respectiva SGN. 
- Captação de recursos: a maioria das plataformas atua facilitando a transação financeira de doações para as organizações sociais e/ou estabelecendo canais em que elas possam angariar recursos e movimentar sua rede de contatos. Algumas empresas vendem as integrações de ferramentas ou produtos visando angariar recursos para as OSCs implementarem em seus websites e outras fornecem os serviços em sua própria plataforma. Muitos websites fornecem serviços de apoio e desenvolvimento para as entidades sociais implementarem suas iniciativas de captação de recursos. O modelo de negócios desse tipo de SGN pode variar da cobrança de percentual de transações financeiras para um sistema de assinaturas com periodicidade específica.

- Serviços de auxílio à OSC e ao doador: essas iniciativas têm o objetivo de orientar e educar doadores a fim de habilitá-los para uma avaliação mais racional e apurada sobre qual organização social apoiar. Esses websites apresentam diversos serviços como educação sobre problemas socioambientais, informações sobre OSCs e a possibilidade de conexão com comunidades de doadores. Normalmente são caracterizados como fundações ou institutos de pesquisa.

- Informações e apurações de OSCs: providenciam informações sobre as causas e o terceiro setor. Alguns websites são descritivos e ajudam o usuário a identificar necessidades e fornecem informações específicas de entidades sociais. As mais famosas plataformas não possuem fins lucrativos e focam notícias e eventos ligados às OSCs, outras providenciam assistência técnica a fim de aumentar a eficiência do terceiro setor.

- Serviços de voluntariado: esses sites têm a missão de facilitar a implementação de tempo e habilidades de um público voluntário em OSCs necessitadas. Dessa forma, atuam estabelecendo a ligação entre OSCs com necessidades específicas de voluntariado e pessoas interessadas em ajudar. Existem empresas - SGNs - com esse tipo de 
serviço. O modelo de negócios geralmente consiste na cobrança de consultoria e atuação com voluntariado corporativo.

- Advocacy e ações sociais: essas iniciativas ajudam as OSCs a estimularem movimentos sociais nas mídias. Também existem plataformas que facilitam a ação participativa de simpatizantes de causas por meio de diversas ações, como assinaturas de petições, participação em atos, entre outros. Podem atuar em consonância com empresas e fundações pelas quais financiam seus serviços.

- Portais de eventos e leilões beneficentes: promovem eventos e leilões beneficentes. Apesar de efetivarem doações online, distinguem-se dos sites de captação de recursos pois realizam eventos e leilões de forma pontual. Seu modelo de negócios consiste na cobrança de percentual de produto leiloado.

- Market-places de e-filantropia: plataformas que apresentam uma gama de produtos e serviços para organizações sociais e doadores, como conexão com oportunidades de voluntariado, doações online e guia para orientar decisões de doação. Seu modelo de negócios geralmente consiste na cobrança de percentual por produto/serviço vendido.

Nota-se que, em quase todas as categorias de serviços em e-filantropia, o relatório destaca o importante papel de empresas na área, viabilizando diversas ações de engajamento social online como a divulgação de oportunidades de voluntariado, leilões beneficentes, captação de recursos digitais, avaliação de organizações sociais, entre outros.

Portanto é verificável que o mercado intersetorial emergente da efilantropia, propiciou o enriquecimento em inovação e inserção digital do terceiro setor. Atuando em parceria com OSCs, as empresas de e-filantropia possibilitaram novas oportunidades e experiências de doação online propiciando uma utilização mais eficiente do meio digital para a conversão de doadores. 
2.3.2. Mercado colaborativo de microdoações: o crowdfunding e a captação Peer-to-Peer.

Segundo Lee (2006), a nova gama de serviços e inovações da efilantropia gerou uma uma cadeia de mercado distinta da captação de recursos convencional introduzindo novos produtos e serviços de angariação. $\mathrm{Na}$ angariação online, destaca- se o fenômeno do financiamento coletivo, sendo popularizadas as plataformas digitais que abordam o poder de rede colaborativa da web utilizando canais de mídias online para angariar microdoações: o crowdfunding e o peer-to-peer.

A fim de aprofundar a técnica $\mathrm{P} 2 \mathrm{P}$, tema desta pesquisa, devido à comum e equivocada noção de se considerarem iguais, será aprofundado o referencial teórico que define e embasa a diferença entre a P2P e a crowdfunding.

Segundo Howe (2006), o crowdfunding é um modelo de financiamento coletivo que busca concretizar projetos de produtos ou serviços a partir de microdoações advindas de usuários interessados na viabilização dessas ideias, de tal modo que gere montante considerável para o financiamento da proposta apresentada.

Por sua vez, a captação de recursos peer-to-peer consiste numa estratégia na qual organizações sociais mobilizam não só sua rede de doadores para fazerem suas campanhas de angariação, mas também sua rede de contatos pessoais, a fim de conseguirem microdoações para a causa (VANHUSS; FULTON, 2017). 
É possível perceber algumas similaridades entre as duas técnicas no que tange à angariação de microdoações e à utilização da rede online para mobilizar as campanhas digitais, o que justifica de certa forma que muitas vezes sejam erroneamente consideradas como iguais. No entanto, apesar de apresentarem congruências, existem algumas diferenças importantes entre ambas as técnicas de angariação online.

Como se pode verificar na Figura 5, enquanto o crowdfunding centraliza o poder de angariação no projeto, o P2P descentraliza o poder de captação do projeto e foca em indivíduos para que criem suas próprias campanhas e mobilizem suas redes para doarem.

De acordo com Hart, Greenfield e Haiji (2007), ambos os métodos têm aplicações específicas, mas no caso de organizações sociais, que têm a constante necessidade de angariação, o P2P apresenta-se como mais apropriado visto que permite a expansão e ativação de novos doadores, devido a seu modelo descentralizado.

\section{Figura 5 - Comparações da mecânica do crowdfunding $\mathrm{x}$ captação de recursos P2P.}
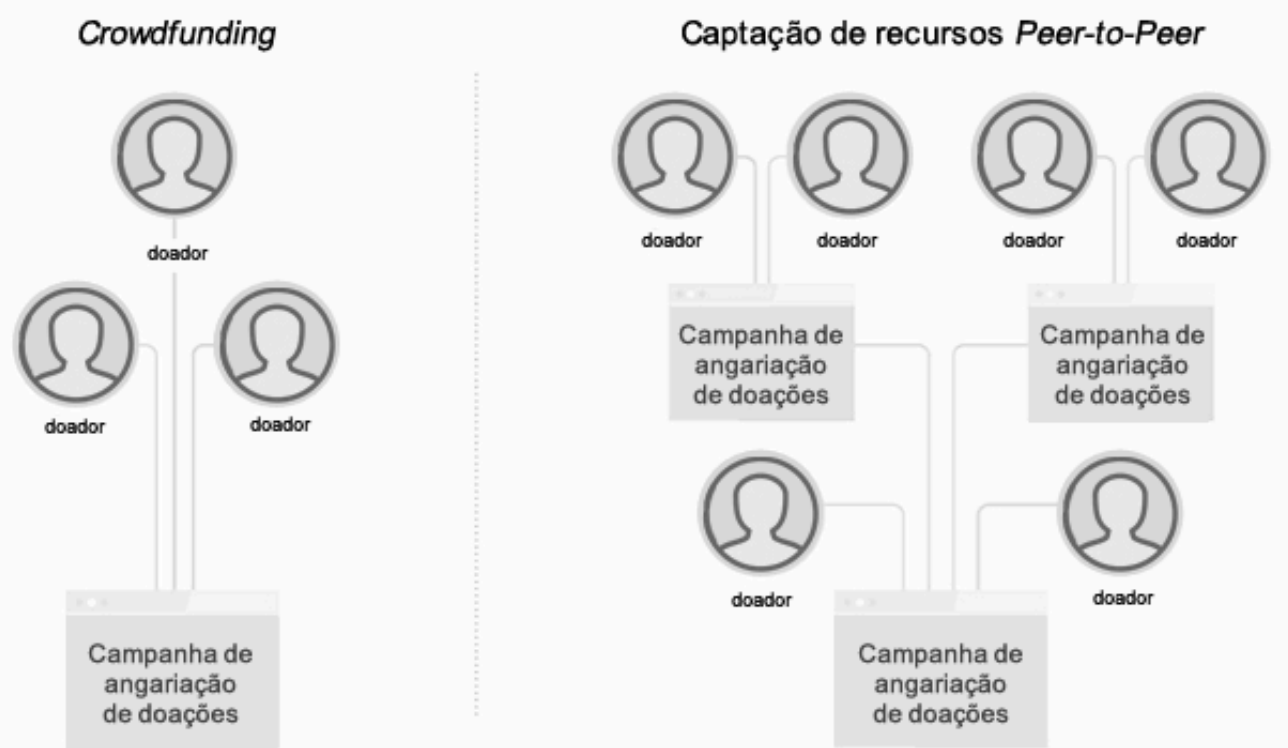

Fonte: Adaptado de Neoncrm, disponível em https://goo.gl/S3BJ4f acesso em 11/06/2017.

Logo, considerando que são estratégias de captação de recursos distintas, estas devem ser indicadas de acordo com o objetivo, o tipo do projeto e 
necessidade de captação financeira.

O crowdfunding pode ser utilizado para projetos pessoais, empresariais ou sociais, atua na captação de recursos de forma unidirecional e centralizada, em que um organizador de campanha requisita o apoio de sua rede e da comunidade da web a fim de financiar um projeto específico. Este projeto tem uma meta de angariação financeira específica que precisa ser conclusa para possibilitar a realização da iniciativa.

Agraval, Catalini e Goldfarb (2013) afirmam que, cada vez mais, as plataformas de crowdfunding estão atuando seguindo uma lógica de mercado, cujas recompensas oferecidas aos apoiadores se trata na realidade de uma venda antecipada de produtos a um público comprador. Portanto, muitas vezes as plataformas de crowdfunding são consideradas marketplaces de produtos, projetos e serviços inovadores os quais são lançados para testar a demanda de mercado e patrocinarem ideias-piloto.

Apesar de o crowdfunding social ser possível e indicado em alguns casos para projetos pontuais de OSCs, para organizações sociais que querem ser sustentáveis em longo prazo e arrecadar recorrentemente online, é mais aconselhado o investimento no P2P visto que essa técnica abre e ativa novos doadores, possibilitando a realização de campanhas de angariação de recursos de modo sustentável e sempre ativando novas redes (PAYNE et al., 2012).

Diferente do crowdfunding, as plataformas de captação de recursos P2P são ferramentas que funcionam somente com organizações sociais, visto a lógica de doação não ser consistente com a lógica de mercado (VANHUSS; FULTON, 2017). Como se pode observar na Figura 5, a estratégia de angariação de "pessoa a pessoa" apresenta potencial ainda mais viral que o crowdfunding visto que sua abordagem descentralizada não apenas possibilita a ação de doação direta dos indivíduos, como também os empodera para a criação de suas próprias campanhas, multiplicando o poder de angariação com suas redes de contatos.

Logo, acerca das técnicas de microdoações online existentes, a literatura acadêmica destaca como mais sustentável e adequado para OSCs o fundraising P2P, que será aprofundado a seguir (HART; GREENFIELD; JOHNSTON, 2005; 
PAYNE et al., 2012).

\subsection{O P2P ou ofriendraising na web 2.0}

Ao refletir sobre as raízes históricas da captação de recursos, Sargeant e Jay (2004) identicam que o método de angariação P2P é antigo e a documentação remonta ao período medieval quando os indivíduos elaboravam cartas pedindo doações para seus contatos a fim de apoiarem organizações religiosas.

No século XX, com o advento dos meios de comunicação, a prática da captação de recursos deixou a personalização para se apropriar dos meios de massa como propagandas em canais de rádio, jornais e televisões. Assim, do pedido que antes era focada no "um a um", as organizações sociais passaram para petições de "um para muitos", a fim de ampliar sua divulgação em escala massiva.

Todavia, com a revolução dos sistemas de informação da década de 1990, a internet quebrou o paradigma existente entre a personalização e massificação, possibilitando que organizações desenvolvessem um tratamento personalizado com escala massiva para seus apoiadores. Isso foi possível devido à segmentação de públicos e automatização do processo de comunicação e construção de relacionamento com potenciais doadores (GOECKS et al., 2008).

Logo, a possibilidade da interatividade digital ao proporcionar a sensação de tratamento pessoal para os doadores em escala massiva e automatizada, somada às características do novo doador web - de protagonismo e envolvimento social - apresentaram especial sinergia e oportunidade para o desenvolvimento da captação de recursos P2P na web.

Como resultado, a técnica protagonizou o desenvolvimento da captação online, considerada uma das técnicas de captação com mais projeção de crescimento segundo Hart, Greenfield e Haji (2007). Esse fenômeno vem sendo comprovado em estudos de empresas e fundações sobre e-filantropia (SINGH; MIDDLETON, 2010; NETWORK FOR GOOD, 2014; BRAITERMAN et al., 2015). 


\subsubsection{A abordagem da técnica do P2P online.}

Apesar de a abordagem da captação P2P se beneficiar com as orientações provenientes das pesquisas de captação de recursos online discutidas no item 2.2.3 desta dissertação, devido às especificidades desta técnica, são discutidos a seguir seus específicos potenciais e boas práticas, apresentados pela bibliografia.

\section{a) O aumento do potencial dialógico da experiência de doação}

Conforme Sargeant (2001), o modelo de marketing tradicional, no qual existe uma proposta de venda replicada para diversas pessoas, perdeu bastante eficiência com as exigências de personalização e interatividade da nova cultura cibernética.

Devido a isso, a tendência para os setores é investir em marketing de relacionamento entre as empresas e clientes, um marketing menos interruptivo e mais harmonizado com os interesses e costumes de seu público-alvo (GODIN, 2006). Transpondo essa nova abordagem para o terceiro setor, o cultivo diferenciado de relacionamento entre as OSCs e sua rede de contatos provenientes pela captação online dá-se por meio de mensagens personalizadas, processos mais interativos e dialógicos (HART; GREENFIELD; JOHNSTON, 2005). Logo, essa nova abordagem de comunicação resulta na maior conversão de doadores, aumento de montantes angariados e envolvimento da pessoa com a causa (GODIN, 2006).

Neste contexto, King e Noble (2007) afirmam que a angariação P2P se torna especialmente adequada visto ser baseada numa comunicação de duas vias, cuja proposta é recontextualizada num discurso moldado pelas relações pessoais entre o emissor e o receptor da mensagem aumentando muito a probabilidade de resposta positiva.

Reforçando ainda mais a suma de que "pessoas doam para pessoas" (NOBLE; KING, p.90), a angariação P2P tem como mecânica de funcionamento 
o relacionamento existente entre o criador das campanhas e sua rede de contatos, potenciais doadores; dessa forma, o aspecto dialógico da angariação de recursos torna-se mais sustentável e natural.

Como exemplo de sua eficiência, o relatório de BRAITERMAN et al. (2016), numa pesquisa realizada com 184 OSCs, indicou que a taxa de conversão de petições de doação por e-mail, quando enviadas por conhecidos a seus destinatários, é de uma eficácia até 300 vezes maior do que ao ser emitida pelas organizações sociais.

Por isso, Andresen e Strathmann (2007) indicam que, ao fazer uma campanha de angariação, é necessário que as pessoas se utilizem dos meios de comunicação personalizando as mensagens de petição para sua rede de contatos. Quanto mais pessoal, maior o potencial de dialogia e relacionamento do novo contato com a OSC, visto que esta é considerada de forma totalmente diferente quando apresentada por seu conhecido.

\section{b) O friendraising e o empoderamento de doadores em líderes de mobilização}

Quanto ao poder das relações pessoais na captação de recursos, Robert Cialdini (2001) declara que as pessoas preferem doar com base na indicação de indivíduos que elas conhecem e gostam. Nessa relação, a doação adquire um outro significado; mais do que uma ajuda para a entidade, a doação atua como uma demonstração de apreciação pelo emissor do pedido (MEER, 2011; SMITH et al., 2012).

A pressão social evidenciada pelo pedido de um ente querido também é destacada como um influenciador da angariação financeira sendo identificados fatores motivadores como, caso o potencial apoiador perceba que está sendo observado publicamente (SOETEVENT, 2005) por normas sociais (FREY; MEIER, 2004; SHANG; CROSON, 2008).

O poder do friendraising foi estudado por Godin (2006), o qual faz referência ao típico funil de marketing - apresentado como funil de doações no item 2.2.3.2 desta dissertação - explicando que a técnica peer-to-peer "derruba" o referido 
funil, transformando-o num "amplificador", ampliando contatos por meio de indivíduos que expandem a divulgação de suas campanhas para suas redes pessoais.

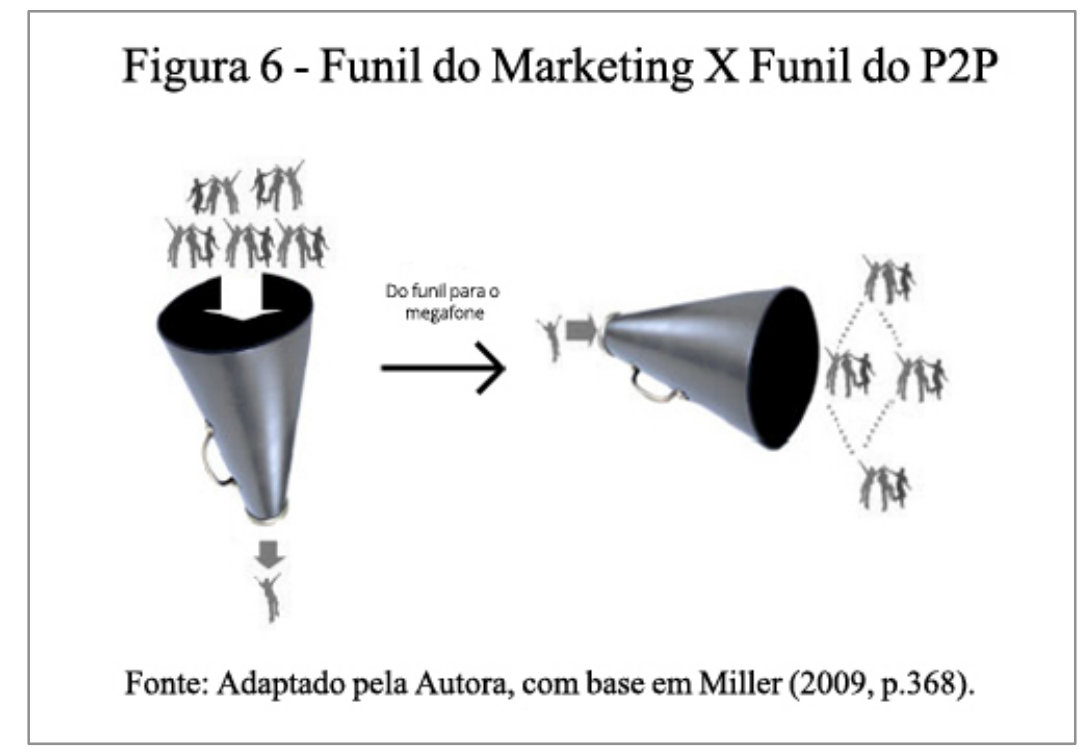

Técnica que tem ainda mais efeito na geração web e torna-se essencial para um "novo marketing", nas palavras de Godin, "uma nova gama de ferramentas online fazem essa abordagem não somente possível, mas também um imperativo para qualquer organização que espera crescer. Dê para o seu fã clube um megafone e saia do caminho" (GODIN, 2006, p.6).

Nesse sentido, a captação online P2P ressalta a importância das organizações em descentralizarem suas atividades, possibilitando ações protagonizadas por seus apoiadores que participam de forma colaborativa, tornando-se eles próprios os captadores de recursos.

Considerando isso, além do potencial de angariação, a técnica é benéfica para as OSCs economizarem em esforços dispostos para a captação. Vanhuss e Fulton (2017) afirmam que, caso trabalhem bem com o engajamento desses líderes, "captadores de recursos amadores", existe um grande potencial da técnica online para viralizar doações e aprofundar o relacionamento com apoiadores-chave, com grande poder de mobilização. 
Segundo Miller (2009), a técnica de atrair novos apoiadores por atividades de "doador atrai doador" da angariação online P2P é especialmente fortalecida pelo fácil compartilhamento de informações nas mídias sociais, nas quais as pessoas somente precisam dividir sua campanha de angariação com sua rede de amigos e familiares a fim de estimular doações para sua iniciativa.

Acerca da divulgação de campanhas P2P nas mídias sociais, as autoras Scharf, Payne e Smith (2015) destacam que o número de amigos em mídias como o Facebook aumenta o potencial de angariação das campanhas, sendo o sucesso proporcional ao número de contatos conectados à pessoa específica. No entanto, ao analisarem as doações em plataforma P2P também se identificou que as pessoas solicitadas pelo facebook tendem a doar quantias menores do que o comum, o que as autoras reconheceram como o fenômeno do "comportamento de carona" - Free ride behavior.

Já abordado por teóricos de captação de recursos, o "comportamento de carona" acontece quando os potenciais doadores, por pressão social, dão um jeito de "driblar" a efetivação de doações sem deixarem de receber reconhecimento público pelo suposto apoio à OSC. No caso das campanhas P2P, o fenômeno pode ocorrer quando pessoas doam valores muito baixos em troca do reconhecimento de seus entes queridos ou elogiam a iniciativa para apoiar seu conhecido sem efetivarem doações.

Além disso, a pressão social também pode estimular o fenômeno do altruísmo competitivo: em busca de distinção social, doadores concorrem nos apoios financeiros efetivados, competindo pelo reconhecimento social de terem doado quantias maiores que seus semelhantes (VUGT et al., 2007).

O altruísmo competitivo pode ser estimulado por plataformas P2P. Scharf, Payne e Smith (2015) em seu estudo de uma plataforma de P2P, chegaram à conclusão de que o fato de as doações terem seu valor aberto publicamente influenciou os valores apoiados pelos doadores, indicando que as pessoas se orientavam por uma média dos valores doados previamente por seu círculo de contatos. 


\section{c) $\mathbf{O}$ poder do storytelling pessoal}

Para Andresen e Strathmann (2007), a história é o coração da eficiência da captação de recursos baseada em pessoas. Quando as pessoas ouvem a história de alguém, elas são transportadas com o contador para outro lugar e tempo, criando uma experiência compartilhada.

Andy Goodman (2015, p.76), expert em storytelling, afirma que "as histórias definem uma pessoa, uma companhia, um movimento, cultura ou nação. Você, como indivíduo, é a soma de todas as histórias que você conta sobre você mesmo". Logo, uma OSC é uma história por si, mas também uma história de sua equipe, doadores e também beneficiários.

Considerando isso, em relação às campanhas pessoais, Andresen e Strathmann (2007) afirmam que o P2P recontextualiza as doações nas histórias pessoais de seus organizadores. É comum que as campanhas de P2P sejam feitas com base em eventos pessoais dos indivíduos, como uma maratona, um aniversário, desafios de esporte entre outros; dessa forma, é colocado nas campanhas um pouco da história da pessoa e da razão de ela estar angariando para aquela organização, contextualizando o público de potenciais apoiadores para a causa por meio da história pessoal do criador da campanha.

Em vista disso, Andresen e Strathmann ressaltam a importância do storytelling nos textos das campanhas de angariação, indicando sua eficiência quanto o mais pessoal possível. Ademais, a criatividade na elaboração das campanhas e a criação de histórias criativas nas quais os desafios pessoais chamam os apoiadores para uma jornada pessoal do organizador ressignificam as doações e aumentam o potencial de notabilidade e sucesso delas.

\section{d) Capitalização e abertura de novas redes de relacionamento para OSCs}

A própria mecânica das campanhas $\mathrm{P} 2 \mathrm{P}$ prova seu poder de possibilitar que apoiadores diretos das OSCs capitalizem sua rede de contatos, proporcionando novas doações para as OSCs. Sob condição dos novos contatos serem bem trabalhados num plano de relacionamento e geração de conteúdo 
relevante das OSCs, é possível converter um percentual dos doadores pontuais que doaram somente para homenagear seu ente querido - em doadores recorrentes (HART; GREENFIELD; HAIJI, 2007).

No entanto é importante ressaltar que o sucesso das campanhas de doação P2P depende do acompanhamento e assessoria que a OSC fornece a esses apoiadores-chave durante todo o processo (ANDRESEN; STRATHMANN, 2007).

É importante também que a OSC ou a plataforma de angariação P2P mantenha o apoiador motivado durante sua campanha, de modo que ele não desista, por cansaço ou saturação, de contatar toda a sua lista de possíveis apoiadores de campanha, grande influenciador do insucesso de angariações apontado por Meer e Rosen (2009).

Para isso podem ser oferecidas recompensas simbólicas (VANHUSS; FULTON, 2017); metas de angariação (SCHARF; PAYNE; SMITH, 2015) ou mesmo oportunidades de maior envolvimento com a causa para o organizador e seus apoiadores por meio da participação em eventos beneficentes ou voluntariado (MILLER, 2009). 


\section{METODOLOGIA}

Neste capítulo é apresentado o trajeto metodológico para a caracterização e estruturação do estudo tendo em vista alcançar os objetivos e responder à questão de pesquisa apresentados no Capítulo 1 desta dissertação.

\subsection{Pesquisa de Mestrado Profissional em Empreendedorismo}

A estrutura desta pesquisa parte da premissa presente na Metodologia de Mestrado Profissional em Empreendedorismo da Faculdade de Administração, Economia e Contabilidade da Universidade de São Paulo (USP) com a finalidade de ressaltar a experiência prática empreendedora que o pesquisador traz para o ambiente acadêmico. Essa proposta coloca em foco o problema emergido da realidade profissional da pesquisadora para buscar na pesquisa acadêmica propostas e hipóteses de solução.

Esse tipo de abordagem tem fundamentação na Teoria da Aprendizagem Experiencial - TAE - elaborado por Kolb (1984).

Preocupado em ampliar a compreensão sobre os diferentes estilos de aprendizagem, Kolb (1984) desenvolveu o modelo de conhecimento por experiências, destacando o papel da vivência prática no processo de aprendizagem ao elaborar um processo no qual a experiência é ponto de partida para a reflexão e desenvolvimento científico.

Kolb (1984) ressalta, no entanto, que, apesar de o ciclo de aprendizagem partir da vivência prática, para a aprendizagem experiencial ocorrer, é preciso aprofundar a experiência obtida: a aprendizagem ocorre na resolução de conflitos entre a teoria e a prática, abstrato e concreto, ou seja, da reflexão prático-teórica sobre ela própria.

Dessa maneira, no ciclo de Kolb (1984), para aprender é necessário dispor das quatro capacidades básicas que são: experiência concreta (EC), 
observação reflexiva (OR), conceitualização abstrata (CA) e experimentação ativa (EA), de cuja combinação surgem os quatro estilos de aprendizagem - o conhecimento acomodado, divergente, assimilativo e o convergente.

Figura 7 - Ciclo da aprendizagem experiencial de Kolb

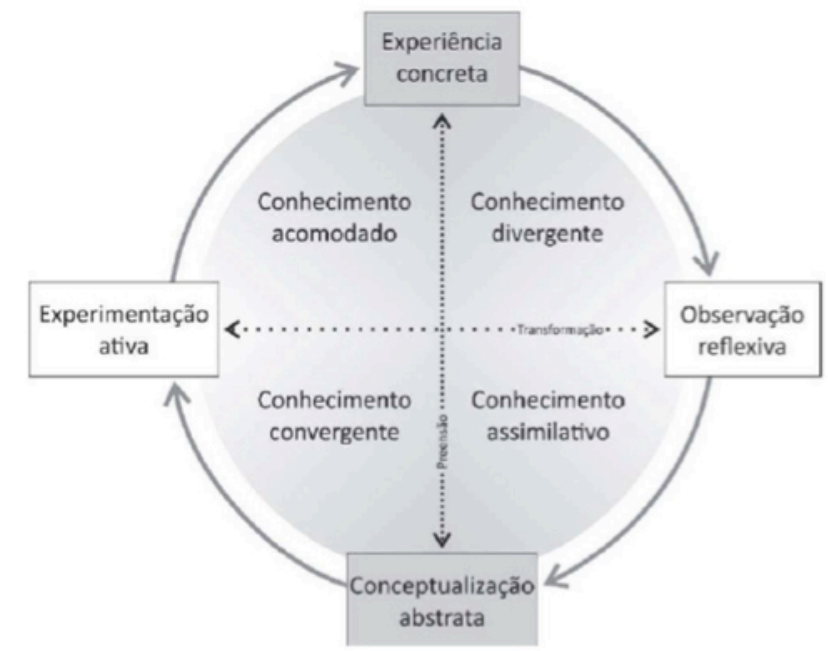

Fonte: Krakauer et al., 2015, p.6.

Segundo Krakauer et al. (2015), a pesquisa de mestrado profissional realiza o ciclo de Kolb (1984), visto que parte da vivência prática do pesquisador entra para a pesquisa por meio da análise dos fatos e descrição da sua experiência ("observação reflexiva"), chegando à relação da experiência prática com o referencial teórico pertinente ("conceptualização abstrata").

A partir da análise e relação entre teoria e prática, o trabalho segue para a exploração do ambiente externo, por meio da coleta de informação dos agentes envolvidos, culminando na contribuição teórico-prática de pesquisa por meio de um plano de intervenção a ser aplicado na prática. Entretanto, para os fins da pesquisa de mestrado profissional, o ciclo conclui-se neste ponto, dado que o escopo de aplicação do plano de intervenção não faz parte da proposta. 


\subsection{Caracterização da Pesquisa}

De acordo com Gil (2012), uma pesquisa pode ser considerada exploratória, descritiva ou explicativa.

Considerando o fato de o fenômeno de angariação digital peer-to-peer ser contemporâneo, com escassa bibliografia específica sobre o tema, a pergunta desta pesquisa demanda compreensão e detalhamento desse processo para entender sua mecânica e potencialidades. Por isso, esta investigação possui natureza exploratório- descritiva.

Em relação à abordagem, esta pesquisa é qualitativa, visto que se buscou entender os dados empíricos resultantes de interações sociais que emergiram das campanhas de angariação digital, logo ela é adequada a esta abordagem pois esta investigação está voltada para o entendimento, compreensão e descrição do comportamento humano, por meio de uma abordagem subjetiva dos dados (MARTINS; TEOPHILO, 2007).

\subsection{Estratégia de Pesquisa: $O$ estudo de caso}

A primeira e mais importante abordagem para se delimitar a estratégia de pesquisa consiste em entender o tipo de questão que está sendo pesquisada.

A questão consiste em "como aumentar a captação de recursos financeiros das campanhas de angariação P2P online?” logo o objeto deste estudo é contemporâneo, baseado num contexto da vida real e procura entender como desenvolver campanhas $\mathrm{P} 2 \mathrm{P}$ de sucesso, sendo necessário mapear e compreender com profundidade a dinâmica e fatores influenciadores desse processo.

Assim, dentro das possibilidades de estratégias oriundas de uma pesquisa com abordagem qualitativa, optou-se pelo estudo de caso como propício para responder aos objetivos da pesquisa, visto que o estudo de caso tem profundidade, detalhamento e é adequado para responder a questões sobre o ‘como' e o ‘porquê' (YIN, 2001). 
Segundo esse autor, o estudo de caso surge do desejo de se compreenderem fenômenos sociais complexos, permitindo "uma investigação para se preservarem as características holísticas e significantes de eventos da vida real" (YIN, 2001, p.32). É uma apuração empírica que "investiga um fenômeno contemporâneo dentro de seu contexto da vida real, especialmente quando os limites entre o fenômeno e o contexto não estão claramente definidos" (YIN, 2001, p.32).

O estudo de caso exploratório é o mais indicado quando o pesquisador busca a compreensão de um problema ou caso. Ainda segundo Yin (1994, p.25), o estudo exploratório tem o "objetivo de desenvolver hipóteses e proposições pertinentes a inquirições adicionais". Sendo assim, a pesquisa enfoca um estudo novo, buscando melhorar a sua compreensão e visando a um aprofundamento posterior.

Ademais, em relação ao objetivo geral desta pesquisa, o de propor boas práticas para campanhas de angariação $\mathrm{P} 2 \mathrm{P}$, os estudos de caso tornam-se ainda mais indicados, visto que não representam uma 'amostra', e o objetivo do investigador é expandir e generalizar teorias (generalização analítica) e não enumerar frequências (YIN, 1994).

Tendo em vista que, para se fazer qualquer pesquisa empírica, é preciso um projeto de pesquisa que consiste na "sequência lógica que conecta os dados empíricos às questões de pesquisa" (YIN, 2001, p.41), a seguir será apresentado o delineamento da pesquisa, tendo como base os elementos considerados importantes por Yin (1994), ao se desenvolver um projeto de estudo de caso: a) as questões de estudo; b) suas proposições; c) unidade(s) de análise; d) a lógica que une os dados às proposições; e) os critérios para se interpretarem as descobertas.

\subsection{Questão de estudo e proposições}

\subsubsection{Questão de Estudo}

Conforme se apresentou, como parte de um Mestrado Profissional em 
Empreendedorismo, o problema de pesquisa surgiu da experiência empreendedora da pesquisadora na empresa Eventos do Bem.

O estudo partiu do funil de pesquisa para o mestrado profissional (KRAKAUER et al., 2015), que se inicia pela reflexão sobre a experiência prática da pesquisadora, e logo se abre para a questão de pesquisa:

"Como aumentar a captação de recursos financeiros das campanhas de angariação P2P online?"

- Quais são as peculiaridades de uma campanha de angariação P2P online?

- Quais fatores influenciam aumentando ou inibindo a probabilidade de angariação de recursos financeiros dessas campanhas?

- Quais as boas práticas possíveis para estimular o seu sucesso?

Para aprofundar e auxiliar na resposta à questão de pesquisa também foi realizado o levantamento teórico seguindo o funil de teoria do mestrado profissional, no qual se partiu dos temas mais abrangentes aos mais específicos (KRAKAUER et al., 2015).

Foi realizado o aprofundamento teórico em artigos, livros e revistas científicas sobre os temas de captação de recursos para o terceiro setor, captação de recursos online para o terceiro setor e os usos da técnica P2P em ambiente digital. 


\section{Figura 8 - Funil teórico da pesquisa}

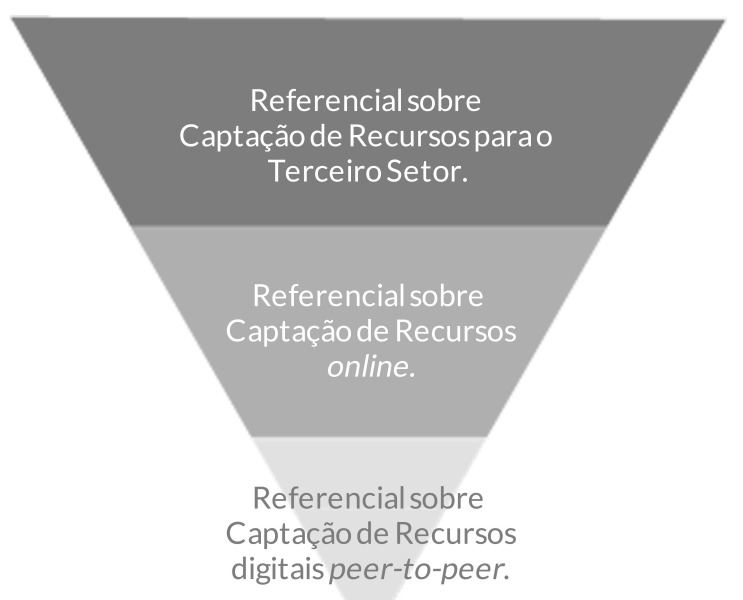

Fonte: A Autora.

Ambas as apurações correspondem respectivamente aos Capítulos 1 e 2 desta dissertação e auxiliaram a elaboração das proposições desta pesquisa.

\subsubsection{Proposições de Pesquisa}

As proposições de pesquisa são importantes num projeto científico para direcionar o olhar do pesquisador. Sem elas, o pesquisador fica tentado a "coletar tudo", inviabilizando sua eficiência e exequibilidade, visto que, principalmente em fenômenos sociais, é impossível abarcar de forma totalizante o estudo da realidade enfocada (YIN, 1994).

Partindo-se do debate da bibliografia acadêmica pertinente ao tema e com foco em responder à questão de pesquisa de "como aumentar a captação de recursos financeiros das campanhas de angariação P2P online?”, foram identificadas as seguintes proposições, divididas em: Fatores dependentes de ações dos Organizadores das campanhas P2P e Fatores provenientes da Plataforma.

Fatores dependentes de ações dos Organizadores das campanhas P2P:

- utilizar storytelling em sua proposta de campanha (ANDRESEN; 
STRATHMANN, 2007; MERCHANT; FORD; SARGEANT, 2010);

- o organizador deve ter a postura proativa de petição de doações para sua rede de amigos e conhecidos que doem para a sua campanha (WASH; LAMPE, 2012; ANDREONI; RAO, 2011);

- utilizar múltiplos canais de divulgação da campanha (HART; GREENFIELD; HAIJI, 2007);

- contatar toda a sua rede de contatos (MEER; ROSEN, 2008);

- personalizar o conteúdo de sua campanha de modo que seja pessoal, relevante e inspirador para sua rede de contatos, atuando com vídeos, imagens e textos pessoais (GARECHT, 2003; CLAYTON, 2009; ANDRESEN; STRATHMANN, 2007).

Fatores provenientes da Plataforma

- investir na usabilidade e responsividade da plataforma (ANDRESEN; STRATHMANN, 2007; MOGUS; LACROAUX , 2005);

- estimular o "altruísmo competitivo": fornecer ferramentas de pressão social para fim de potencializar as campanhas (SHANG; CROSON, 2009; VUGT et al., 2007; SCHARF; PAYNE; SMITH, 2015);

- fornecer ferramentas de interação dialógica entre doador e organizador (INGENHOFF; KOELLING, 2009; SARGEANT et al. 2007);

- implementar certificados de segurança e criptografia de dados e comunicar confiança para os doadores em relação à transação financeira (POLLACH, 2005; RYKER et al., 2005; MEINERT et al., 2006; KIMERY; MCCORD, 2006);

- assessorar o organizador nas campanhas de angariação $\quad$ P2P (ANDRESEN; STRATHMANN, 2007);

- possibilitar a integração e compartilhamento das campanhas nas mídias sociais (MILLER, 2009). 


\subsection{Tipo de estudo caso e unidades de Análise}

Segundo Yin (1994), ao se definir um projeto de estudo de caso, é importante selecionar também a unidade de análise, que está ligada à maneira pela qual as questões de estudo foram definidas, podendo ser única ou múltipla.

As possibilidades de projetos de estudos de caso, aliadas às variações quanto à suas unidades de análise, resultaram na matriz $2 \mathrm{X} 2$ a seguir :

Figura 9 - Matriz dos projetos de estudo de caso

\begin{tabular}{c|c|c|}
\multicolumn{1}{c}{} & \multicolumn{1}{c}{$\begin{array}{c}\text { Caso } \\
\text { Único }\end{array}$} & $\begin{array}{c}\text { Casos } \\
\text { Múltiplos }\end{array}$ \\
\cline { 2 - 3 } $\begin{array}{c}\text { Unidade } \\
\text { de Análise } \\
\text { Única }\end{array}$ & $\begin{array}{c}\text { TIPO } \\
\text { I }\end{array}$ & $\begin{array}{c}\text { TIPO } \\
\text { III }\end{array}$ \\
$\begin{array}{c}\text { Unidade } \\
\text { de Análise } \\
\text { Múltipla }\end{array}$ & $\begin{array}{c}\text { TIPO } \\
\text { II }\end{array}$ & $\begin{array}{c}\text { TIPO } \\
\text { IV }\end{array}$ \\
\cline { 2 - 3 } & & \\
& &
\end{tabular}

Fonte: Yin, 1994, p.39.

- Projeto do Tipo I - composto por estudo de caso único e uma unidade de análise;

- Projeto do Tipo II - composto por estudo de caso único e múltiplas unidades de análise;

- Projeto do Tipo III - composto por estudos de caso múltiplos e uma unidade de análise;

- Projeto do Tipo IV - composto por estudos de caso múltiplos e múltiplas unidades de análise.

Nesta pesquisa optou-se por realizar o projeto do tipo IV, de estudos de caso múltiplos com múltiplas unidades de análise. A escolha desse tipo de projeto de pesquisa dá-se devido à lógica de replicação e à generalização analítica proveniente dos estudos de caso múltiplo (YIN, 1994), o que permite o alcance dos objetivos geral e específicos deste estudo, os de identificar fatores, 
reconhecer padrões e compor boas práticas nas campanhas de angariação peerto-peer.

Dessa forma, os casos consistem: (a) na plataforma web empreendida pela própria autora; (b) numa plataforma selecionada, referência neste tipo de angariação. Por conseguinte, as unidades de análise consistem nas campanhas de angariação peer- to-peer realizadas nos casos selecionados.

\subsection{Modelo de pesquisa}

A fundamentação teórica desta pesquisa identificou que os fatores influenciadores do sucesso das campanhas são oriundos de ações elencadas por dois sujeitos participantes do processo de angariação:

a) ações da plataforma (subtendendo-se ações da equipe de funcionários)

- que auxiliam os organizadores de campanhas com técnicas que aumentam o potencial de angariação para suas campanhas e fornecem suporte técnico viabilizando as campanhas online;

b) ações do organizador das campanhas - deve ser proativo em montar uma campanha que gere apelo, personalizando suas petições com textos e imagens, e mobilizando propriamente sua rede de apoiadores de forma que convertam doações para sua campanha. 
É importante ressaltar que se restringiu a levantar fatores passíveis de serem desenvolvidos proativamente para o sucesso das campanhas, portanto os apoiadores financeiros não foram considerados como sujeitos ativos no processo, visto que sua ação de apoiar campanhas não é proativa, mas ativada pelo pedido do organizador da campanha.

Além disso, considerando a natureza exploratória da pesquisa, foi prevista a possibilidade de emergirem outras proposições no decorrer do estudo, as quais serão consideradas na análise de dados e resultados desta dissertação.

As proposições identificadas se resumem na Figura 10.

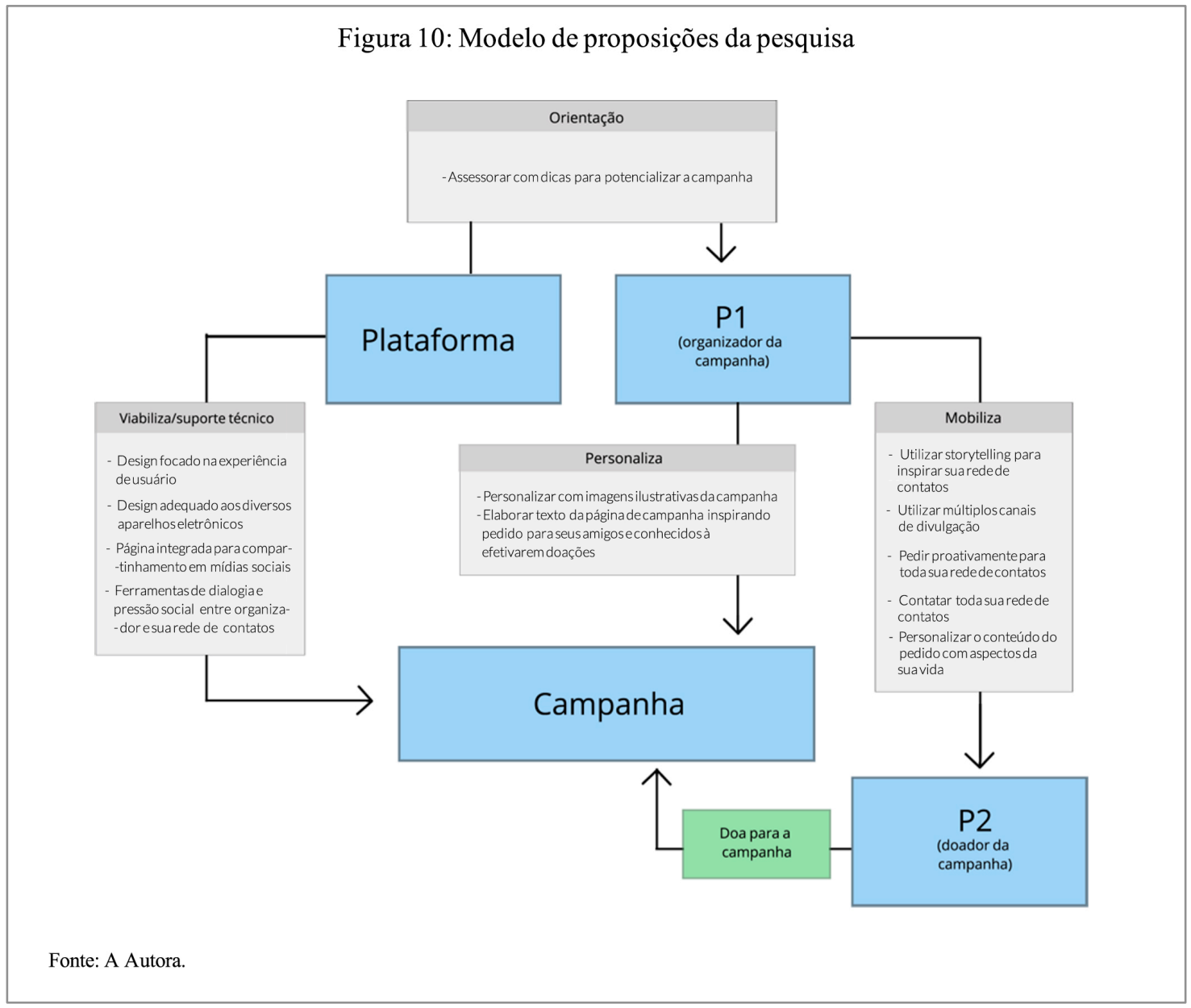

\subsection{Coleta e análise dos dados}

\subsubsection{Casos}

Segundo YIN (1994), no estudo de casos múltiplos deve-se seguir uma 
lógica de replicação, ou seja, cada caso deve comprovar ou negar determinado aspecto da teoria que está sendo testada. $\mathrm{O}$ autor ressalta também que precisam ser escolhidos casos representativos para inclusão no estudo qualitativo os quais devem ser cuidadosamente selecionados pelo investigador no início da investigação.

Sendo este um Mestrado Profissional em Empreendedorismo, o primeiro estudo de caso abordou o próprio empreendimento da autora: a plataforma Eventos do Bem. Além da riqueza e acessibilidade de 100\% das informações necessárias para a pesquisa, esta seleção se justifica devido à plataforma Eventos do Bem ser o caso brasileiro pioneiro em angariação P2P e portanto altamente relevante como objeto de estudo da temática em contexto nacional.

Em relação à escolha da segunda plataforma de angariação online peerto- peer, os parâmetros de seleção foram os seguintes:

- uma plataforma web com histórico de arrecadação financeira notável e referência como caso de sucesso na técnica P2P;

- uma plataforma que fosse reconhecida pela especificidade de realização de campanhas de angariação pessoais de aniversários e eventos provenientes da vida dos organizadores;

- acessibilidade e disponibilidade de contribuição do corpo de funcionários para a coleta de dados da pesquisa.

Em vista disso, orientou-se a seleção com base em pesquisas em portais conhecidos de captação de recursos para o terceiro setor como peertopeerforum.com, npengage.com e charitynavigator.org.

Por meio da pesquisa entre os portais, ficou esclarecido que as campanhas de captação P2P podem apresentar-se de duas formas: (1) campanhas desenvolvidas com base num evento maior como uma maratona ou corrida de ciclismo; (2) campanhas pessoais, das quais os organizadores criam campanhas sem estarem afiliadas a eventos maiores, mas com base em razões pessoais e eventos de suas vidas, como aniversários.

De acordo com os parâmetros mencionados, para estabelecer uma análise sobre as mesmas bases de referência, delimitou-se para a seleção de uma plataforma de referência na elaboração de campanhas pessoais de aniversário, 
visto a esta ser a categoria mais recorrente do contexto deste problema desta pesquisa.

Considerando o foco de seleção, os portais P2P Professional Forum, Charityscience e relatórios de empresas sobre o assunto, indicavam como mais famosa e pioneira na categoria de campanhas pessoais de aniversário, a plataforma Charity:Water (PLENTY CONSULTING, 2015; BRAITERMAN et al. 2016, NETWORK FOR GOOD, 2015).

Com plataforma tecnológica própria, a Charity:Water $(\mathrm{CW})$ é referência em campanhas de angariação pessoal como aniversários, angariando mais de 12 milhões de dólares em mais de 90 mil campanhas de aniversário realizadas.

O modelo de captação online por campanhas de aniversário da organização obteve tanto sucesso que se expandiu para outras organizações conhecidas - como as OSCs Pencils of Promise e Livestrong - além de ter inspirado empresas a desenvolverem serviços de captação de recursos online com base nas campanhas de angariação pessoal. Uma dessas empresas é a Classy, plataforma-líder em oferecimento de serviços de angariação online para OSCs, na qual Scott Harrison - fundador da CW - faz parte do conselho administrativo.

Em vista disso, é importante ressaltar que na escolha dos dois casos Eventos do Bem e Charity:Water - foi considerado o contraste da natureza deles: um se trata de uma empresa privada e o outro, de uma OSC. No entanto, ao considerar que a unidade de análise desta pesquisa são as campanhas de angariação peer-to-peer e seus objetivos são os fatores e boas práticas influenciadoras delas, a diferença jurídica das promotoras das campanhas não se apresentou como um fator influenciador da base de análise. Ademais, considerase que o histórico de replicação de boas práticas da organização é possível para empresas privadas visto o caso mencionado, em que o CEO - Scott Harrison faz parte da equipe fundadora da empresa Classy.

Quanto à seleção das campanhas, estas foram escolhidas de acordo não apenas pela disponibilidade dos respectivos organizadores de participarem das entrevistas, como também por meio de uma busca no histórico de campanhas de aniversário disponível nas plataformas selecionadas.

Outro critério analisado foi o parâmetro de caracterização de seu sucesso ou insucesso financeiro. 
Considerando-se que as campanhas possuem diversas metas estabelecidas pelos organizadores, devido à disparidade de montantes almejados, alcançar $100 \%$ da meta não pareceu o critério mais apropriado devido à diferença de desafios de angariação, por exemplo, entre campanhas de meta de U\$10,000 e outras U\$200.

Como solução, considerou-se como critério o tíquete-médio de angariação de campanha das plataformas Eventos do Bem e Charity:Water, assim, as campanhas consideradas bem-sucedidas foram as que ultrapassaram o tíquete-médio de angariação de cada plataforma.

Ademais, a seleção das campanhas seguiu um modelo de contrastar abordagens e resultados, por isso não se restringiu às campanhas bem-sucedidas, mas também foram consideradas aquelas que angariaram abaixo do tíquetemédio esperado. Partindo dessa abordagem, buscou-se identificar divergências entre os resultados e práticas implementadas, verificar padrões de "boas" e "más" práticas de angariação $\mathrm{P} 2 \mathrm{P}$ para, assim, rivalizar proposições sobre a interferência de fatores e práticas no sucesso desse tipo de angariação, proporcionando uma análise mais aprofundada.

\subsubsection{Técnica de coleta de dados}

Pelo fato de a pesquisa partir da consideração da realidade, em sua ampla gama de perspectivas e considerações, Yin (1994) sugere que para uma boa análise é necessária a apuração de dados de diversas fontes de evidência, de modo que se possa fazer a triangulação. O uso de múltiplas fontes de evidência nos estudos de caso permite que o investigador aborde uma variação maior de aspectos históricos e comportamentais. Além disso, o autor ressalta que a principal vantagem no uso de várias fontes é o desenvolvimento de linhas convergentes de investigação, seguindo um modo corroborativo de triangulação de dados que identifiquem fenômenos e padrões.

Acerca dos tipos de fontes de evidência, Yin (1994) apresenta: (a) a documentação; (b) o registro em arquivos; (c) entrevistas; (d) observações diretas; (e) observação participante e (f) artefatos físicos.

Pelo fato de esta pesquisa estar no campo do Mestrado Profissional em 
Empreendedorismo cujo problema de estudo emergiu da experiência prática da pesquisadora, no caso da plataforma Eventos do Bem, as fontes de evidência consistiram no relato de experiências da autora e empreendedora da referida empresa e em entrevistas com pessoas que fizeram campanhas de angariação P2P na plataforma.

Considerando que a autora não atuou profissionalmente na promoção da plataforma Charity:Water, alguns cuidados foram considerados para garantir não apenas a consistência dos dados obtidos, mas também a realização do cross-case de modo equilibrado e equânime.

Logo, em concomitância com a equipe profissional da Charity:Water, a pesquisadora esteve em Nova Iorque - sede da CW - em abril e maio de 2017, quando participou em reuniões, testes de experiência do usuário e entrevistas com os membros da equipe da Charity: Water nos quais foram discutidos a fundo os fatores influenciadores e boas práticas aprendidas das campanhas P2P. Além disso, também foram realizadas entrevistas com as pessoas que organizaram campanhas de aniversário na plataforma.

Dessa forma, a estrutura de coleta e análise de dados neste trabalho baseou-se no modelo proposto por Yin (1994), adaptado para esta pesquisa, como se vê na Figura 11.

Figura 11- Estrutura de coleta e análise dos estudos de caso múltiplos desta dissertação.

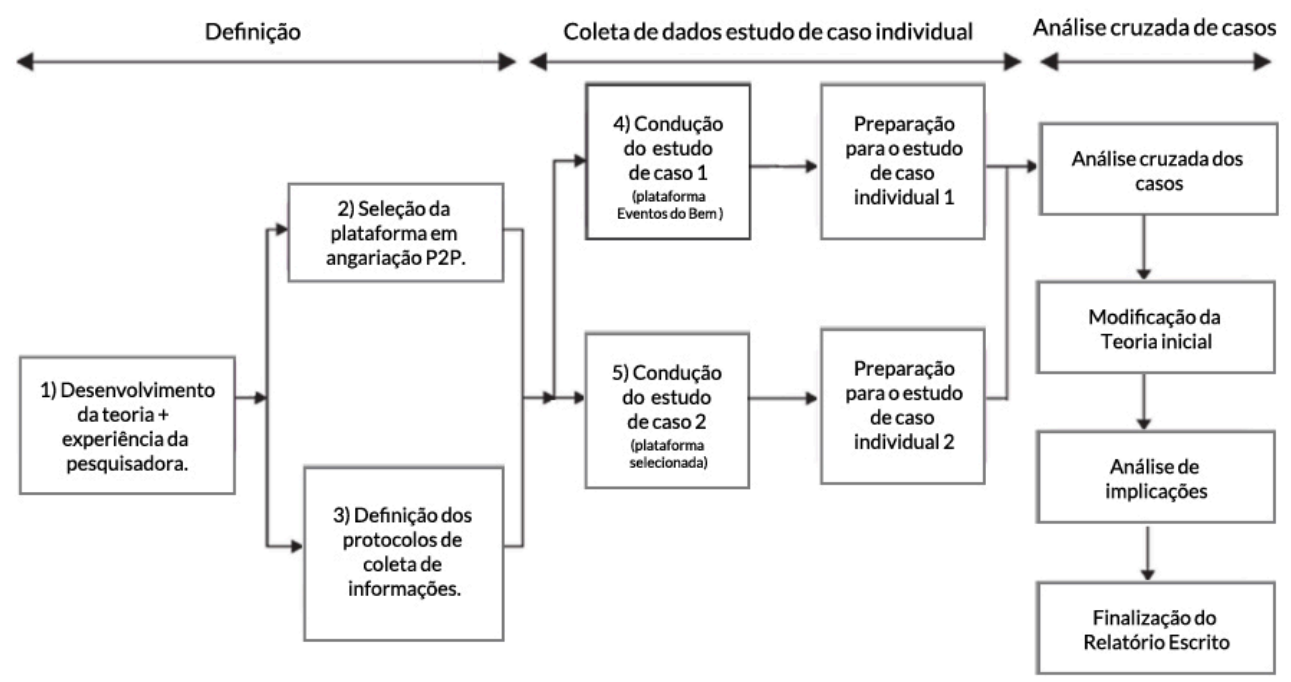

Fonte: Elaborado pela Autora, com base em Yin (1994) 
- Fase 1: levantamento da experiência da pesquisadora e da fundamentação teórica a fim de fornecerem subsídios para o aprofundamento do contexto e experiências de captação online; seleção do caso a ser estudado e definição do protocolo de coleta de informações com base nos pressupostos levantados na pesquisa e fundamentação bibliográfica;

- Fase 2: realização do estudo dos casos selecionados, pela coleta de documentação referente às plataformas e realização de entrevistas; aprofundamento e interpretação dos dados primários obtidos em cada caso estudado; produção de relatório de cada caso;

- Fase 3: análise cruzada entre as evidências de cada caso, implicações nos pressupostos iniciais e bibliografia-base; relatório de casos cruzados com identificação de boas práticas evidenciadas pela análise cruzada.

Todas as etapas da pesquisa de obtenção e análise de dados primários e secundários foram planejadas de forma que atendam a questão e objetivos delineados no Capítulo 1 desta dissertação.

No Quadro 2, apresenta-se a relação entre a questão, objetivos de pesquisa com a estruturação e processo metodológico.

Quadro 2 - Relação de objetivos e métodos da pesquisa

\begin{tabular}{|l|c|c|}
\hline \multicolumn{2}{|c|}{ Questão de Pesquisa: Como estimular campanhas P2P de sucesso? } \\
\hline \multicolumn{1}{|c|}{ Objetivos } & Métodos & Fase da Pesquisa \\
\hline $\begin{array}{l}\text { Identificar os fatores relevantes para o sucesso } \\
\text { de campanhas P2P realizadas na plataforma }\end{array}$ & $\begin{array}{c}\text { Relato da Experiência, } \\
\text { fontes primárias e secundárias, } \\
\text { entrevistas. }\end{array}$ & 1 e 2 \\
\hline $\begin{array}{l}\text { Eventos do bem. } \\
\begin{array}{l}\text { Identificar fatores relevantes para o sucesso } \\
\text { plataforma selecionada. }\end{array}\end{array}$ & $\begin{array}{c}\text { Fontes primárias e } \\
\text { secundárias, entrevistas. }\end{array}$ \\
\hline $\begin{array}{l}\text { Reconhecer padrões das campanhas de sucesso } \\
\text { analisados na plataforma brasileira e no caso } \\
\text { selecionado. }\end{array}$ & $\begin{array}{c}\text { Análise comparativa dos } \\
\text { relatórios individuais } \\
\text { dos estudos de caso. }\end{array}$ & 3 \\
\hline $\begin{array}{l}\text { Estruturar ações que contribuam para o } \\
\text { sucesso das campanhas nacionais de angariação } \\
\text { peer-to-peer. }\end{array}$ & $\begin{array}{c}\text { Análise comparativa dos } \\
\text { relatórios individuais } \\
\text { dos estudos de caso. }\end{array}$ & 3 \\
\hline
\end{tabular}

Fonte: A Autora. 
Segundo a estrutura desta pesquisa, optou-se pelas fontes de evidência de documentação, relatos e entrevistas.

\subsubsection{Documentação}

A pesquisa e levantamento de documentação foi bastante direcionada segundo o problema e os pressupostos dele derivados (conforme ilustrado na Figura 10 desta dissertação).

Considerando que a unidade de análise consiste em campanhas de angariação P2P virtuais, a documentação apurada é proveniente principalmente de meio eletrônico e portais da internet.

Em relação ao layout e design da plataforma, foi feita uma análise das páginas eletrônicas das plataformas com o auxílio do software presente no portal web.archive.org. O referido portal pertence à organização sem fins lucrativos, Internet Archive, cujo objetivo é constituir o maior arquivo com versões antigas de diversos websites, a fim de mostrar a evolução da web. Com recomposições desde o ano de 2000 até a atualidade, o acervo pretende manter uma cópia digital para consulta histórica, sendo possível a pesquisa e análise de mudanças de layout e funcionalidades de milhões de websites documentadas.

Para a análise dos casos, a ferramenta foi bastante propícia, pois, considerando-se a dinamicidade da web na mudança de layouts e funcionalidades das plataformas, foi possível recompor as páginas de campanha dos entrevistados, permitindo a análise do layout exato do momento em que fizeram a campanha. Além disso, facilitou traçar uma evolução em questão de design, layout e funcionalidades das plataformas estudadas.

Em conjunto, a fim de garantir a preservação dos dados, foi realizada a conservação em imagem tirando-se uma fotografia - print screen - de cada campanha de angariação virtual com o auxílio do software Fire Shot Options.

Esses documentos foram facilitados com a consulta de outros documentos de assessoria das plataformas aos criadores de campanhas, como dicas para melhorar o desempenho da angariação, casos de sucesso, relatórios, e-mails marketing enviados, entre outros. 
Em conjunto, considerando que não foi possível realizar-se a entrevista com o fundador da OSC, visto sua indisponibilidade de agenda, para compor a história da Charity:Water, foram considerados textos e um vídeo presente no website da organização. Importante ressaltar que este material foi utilizado somente para estabelecer o histórico da entidade, ademais as informações foram conflitadas com entrevistas de funcionários e um dos organizadores entrevistados que esteve em contato com a OSC desde o início.

\subsubsection{Entrevistas}

A fim de compreender com mais profundidade os casos, identificar elementos de interação e comportamento humano que não são possíveis de serem verificados nos documentos, optou-se por realizar entrevistas semiestruturadas focadas.

Segundo Gil (2012), as entrevistas são fontes essenciais de informação para os estudos de caso, compondo-se em conversas guiadas, não estruturadas, para a obtenção de dados em profundidade acerca dos mais diversos aspectos da vida social. Além disso, é uma técnica flexível, já que possibilita esclarecer o significado da pergunta e adaptar-se mais facilmente às pessoas e à circunstância em que é amostrada.

Os sujeitos selecionados para as entrevistas foram 6 funcionários da plataforma Charity:Water que atuavam diretamente com as campanhas de angariação online, e 20 organizadores de campanhas de cada plataforma estudada, totalizando no estudo de 40 campanhas realizadas nas plataformas Eventos do Bem e Charity: Water.

\subsubsection{Preparação das Entrevistas}

Conforme afirma Gil (2012), a realização de entrevistas de qualidade é resultante de um processo de medidas de preparação no qual é preciso se estabelecer e entender a postura necessária do entrevistador, garantir ferramentas que viabilizem sua realização, preparar os aparelhos para gravação das conversas 
(se possível), formular e testar as perguntas e, por fim, selecionar a amostragem a ser abordada. Essas etapas foram realizadas nesta pesquisa e serão apresentadas a seguir.

\section{a) Boa postura do entrevistador}

De acordo com Yin (2001), um bom pesquisador de estudo de caso deve ser capaz de formular boas questões e interpretar as respostas; além disso, deve ser um bom ouvinte sem enviesar a pesquisa tendenciando as respostas dos entrevistados. Esses fatores foram bastante considerados nas entrevistas, procurando-se não interromper o entrevistado e fazer perguntas em caso de dúvidas e, em relação à boa compreensão das afirmações do entrevistado, algumas vezes foi pedido ao entrevistado para confirmar ou negar se realmente quis expressar o que foi compreendido pelo entrevistador.

\section{b) Garantir ferramentas necessárias para a realização das entrevistas e, se possível, gravação delas.}

Com exceção de duas - que não foram gravadas devido a problemas técnicos - as entrevistas foram realizadas com o aplicativo Call Recorder. O resultado consistiu em entrevistas de boa qualidade de áudio e suas gravações utilizadas posteriormente para a transcrição e análise de conteúdo. Ademais, os entrevistados autorizaram a reprodução e utilização das entrevistas nesta pesquisa.

\section{c) Formular e testar as perguntas.}

Para a formulação de boas questões foi feito o levantamento de documentos, a análise prévia da plataforma e das campanhas, bem como a leitura bibliográfica referente à angariação de recursos não só online mas também peerto-peer. Isso permitiu serem refinadas as perguntas e elaborados os protocolos de entrevistas.

Segundo Yin (2001), as questões do protocolo de estudos de caso devem permitir distinguir os diversos níveis de questão de acordo com os sujeitos entrevistados. Por isso foram realizados dois protocolos: um direcionado aos 
funcionários e outro, aos organizadores das campanhas.

Cada protocolo de estudo de caso foi dividido por blocos temáticos para, assim, direcionar o entrevistador sobre objetivos e aprendizados específicos almejados em cada seção de perguntas.

\section{Protocolo de Estudo de Caso para Funcionários}

Bloco 1: Dados pessoais e cargo na Organização.

Bloco 2: Questões sobre as especificidades e diferenciais da Charity:Water.

Bloco 3: Questões sobre o layout, design e experiência de usuário da plataforma. Bloco 4: Perguntas para identificar e compreender como a plataforma estimula a captação de novos organizadores de campanhas para a causa.

Bloco 5: Entender, caso exista, a assessoria e acompanhamento fornecido aos organizadores de campanha a fim de potencializar o resultado financeiro delas.

Bloco 6: Filtrar informações e aprendizados da plataforma com a técnica P2P, quais modalidades de eventos funcionam melhor, como potencializar certos tipos de modalidade.

Bloco 7: Aspectos relacionados aos diferenciais da $\mathrm{CW}$, sendo este o seu modelo de sustentabilidade financeira e as inovações em transparência e prestação de contas dos recursos investidos na organização.

Bloco 8: Entender o relacionamento com parceiros e empresas.

\section{Protocolo de Estudo de Caso para os Organizadores das campanhas}

Bloco 1: Dados pessoais e da rede de mídias sociais que o entrevistado possui conta.

Bloco 2: Questões para entender a disposição pro-social antes de se criar a campanha, se foi inspirada a ser ajudada pela organização ou pela causa específica.

Bloco 3: Compreender a experiência do usuário na plataforma ao se criar a 
campanha, análise de influências do conteúdo disposto pelo organizador na plataforma online

Bloco 4: Conhecer a assessoria da plataforma, para compreender práticas realizadas pela plataforma para auxilixar o organizador.

Bloco 5: Identificar e entender ações mobilizadas pelo organizador proatividade em divulgar a campanha, ideias de divulgação, materiais produzidos - benéficas ou inibidoras do potencial de sucesso financeiro das campanhas.

Bloco 6: A "pós-campanha": avaliação da experiência e de interação do organizador com a plataforma e sua rede, proveniente da campanha.

Após a elaboração dos protocolos, foram realizados os testes-piloto de cada protocolo. Foram seguidas as orientações de Yin (2001), o qual indica a seleção de casos pela conveniência e facilidade de acesso. Dessa forma, a aplicação dos protocolos teve função experimental, permitindo a observação de diferentes fenômenos a fim de serem apuradas as melhores práticas de abordagem.

A partir da experimentação dos protocolos-piloto, foram redigidos os respectivos relatórios, explicitadas as lições aprendidas, tanto para o projeto de pesquisa quanto para os procedimentos de campo.

Em relação ao protocolo-piloto, para os funcionários da Organização, notou-se a necessidade de se conhecer bem o organograma da empresa, bem como os cargos e funções, pois alguns dos blocos temáticos não eram passíveis de serem respondidos pelos funcionários da área abordada. Outro aprendizado se deu no protocolo-piloto dos organizadores de campanhas no qual foi necessário se alterarem algumas perguntas que não estavam tão claras para a compreensão dos entrevistados.

\section{d) Seleção da amostragem}

Uma questão que se coloca no estudo de casos múltiplos é o número de casos que se deve estudar. Para Yin (2001) o número de entrevistados num estudo de caso não pode ser previamente estabelecido com precisão, pois depende da visão do pesquisador quanto à robustez dos dados e do critério de saturação qualitativa. Esse tipo de critério propõe que se tomem tantos 
entrevistados para a pesquisa quantos forem necessários para as questões que se pretende explorar serem suficientemente cobertas (CRESWELL, 2010; PATTON, 1990; YIN, 2001).

Logo, seguindo o critério de saturação qualitativa das entrevistas, no estudo do primeiro caso chegou-se à análise de 20 campanhas, das quais 7 foram bem- sucedidas, 3 foram consideradas muito bem-sucedidas (visto angariarem em grandeza 3 vezes maior que o tiquete-médio), e 10 ficaram abaixo do tíquetemédio (TM) esperado. Esse número de entrevistas e categorias de performance foi padronizado para o caso seguinte.

A abordagem de casos contrastantes foi escolhida devido a fundamentação teórica apontar também a existência de fatores inibidores de sucesso das campanhas, por isso aquelas que arrecadaram aquém do esperado foram selecionadas para não apenas identificar e analisar essas proposições, bem como, por antítese, comparar e identificar boas práticas provenientes da ausência das ações inibidoras.

Em suma, seguindo os passos indicados por Creswell (2010), a preparação das entrevistas foi feita com base nos seguintes critérios e pontos do processo: (a) identificar os entrevistados; (b) determinar qual o tipo de entrevista possível que dará ao investigador a melhor informação para poder responder às perguntas da investigação; (c) utilizar equipamento adequado para a coleta dos dados; (d) conceber e empregar um protocolo de entrevista; (e) melhorar as perguntas e os procedimentos por meio de um teste-piloto; (f) definir o local da entrevista; (g) obter o consentimento do entrevistado para participar do estudo.

\subsubsection{Realização das entrevistas}

As entrevistas foram elaboradas com um roteiro de perguntas abertas. Considerou-se que perguntas adicionais surgissem à medida que os entrevistados narrassem suas experiências. Assim, permitiu-se considerar visões e questões, não previstas anteriormente, possibilitando conteúdos relevantes para a pesquisa, que pudessem surgir durante a entrevista (MALHOTRA, 2001).

Após a realização das entrevistas, houve a transcrição e validação dos achados com o entrevistado, a fim de garantir a qualidade das informações coletadas (FLICK, 2009). 


\section{a) Caso 1 - Eventos do Bem}

Tendo em vista a origem da questão de pesquisa, o primeiro caso a ser abordado foi o da empresa Eventos do Bem. Foram entrevistadas 20 pessoas que fizeram campanhas na plataforma, totalizando 9 horas e 5 minutos de entrevistas; 10 organizadores realizaram campanhas de sucesso (acima do tíquete-médio da empresa de $\mathrm{R} \$ 800,00$ por campanha) e 10 organizadores não atingiram o valor médio.

As entrevistas foram realizadas com vistas a entender e contrastar padrões de ações de campanhas que deram certo e as que ficaram aquém do valor angariado, a fim de compreender quais ações realmente foram determinantes para mobilizar doações para as campanhas. Em conjunto, questões relativas ao apoio técnico da plataforma e sua assessoria foram verificadas. Além disso, tentou-se assegurar a veracidade das respostas frisando, antes de serem formuladas as questões, para todos os organizadores a importância de serem sinceros e da anonimidade que teriam na presente pesquisa.

No Quadro 3, apresentam-se os organizadores entrevistados, realizadores das campanhas da plataforma Eventos do Bem. 
Quadro 3 - Entrevistas e documentos do Caso 1: Eventos do Bem

\begin{tabular}{|c|c|c|c|c|}
\hline Entrevistado & Meio & Gravação & Duração & $\begin{array}{l}\text { Status da campanha } \\
\text { quanto ao Ticket Médio }\end{array}$ \\
\hline C1_E1 & Skype & Sim & $00: 44: 23$ & acima do TM \\
\hline C1_E2 & Skype & Sim & $00: 17: 00$ & acima do TM \\
\hline C1_E3 & Skype & Sim & $00: 48: 35$ & bem acima do TM \\
\hline C1_E4 & Skype & Sim & $00: 25: 38$ & bem acima do TM \\
\hline C1_E5 & Skype & Sim & $00: 37: 00$ & acima do TM \\
\hline C1 E6 & Skype & Sim & $00: 19: 49$ & acima do TM \\
\hline C1 E7 & Skype & Sim & $00: 36: 29$ & bem acima do TM \\
\hline C1_E8 & Skype & Sim & $00: 27: 20$ & acima do TM \\
\hline C1_E9 & Skype & Sim & $00: 59: 49$ & bem acima do TM \\
\hline C1_E10 & Skype & Sim & $00: 15: 54$ & acima do TM \\
\hline C1_E11 & Skype & Sim & $00: 13: 57$ & abaixo do TM \\
\hline C1_E12 & Skype & Sim & $00: 18: 43$ & abaixo do TM \\
\hline C1_E13 & Skype & Sim & $00: 26: 47$ & abaixo do TM \\
\hline C1_E14 & Skype & Sim & $00: 21: 39$ & abaixo do TM \\
\hline C1_E15 & Skype & Sim & $00: 22: 35$ & abaixo do TM \\
\hline C1_E16 & Skype & Sim & $00: 12: 37$ & abaixo do TM \\
\hline C1_E17 & Skype & Sim & $00: 18: 05$ & abaixo do TM \\
\hline C1_E18 & Skype & Sim & $00: 33: 33$ & abaixo do TM \\
\hline C1_E19 & Skype & Sim & $00: 26: 47$ & abaixo do TM \\
\hline C1_E20 & Skype & Sim & $00: 18: 40$ & abaixo do TM \\
\hline \multicolumn{5}{|c|}{20 pessoas entrevistadas no total de 9:05:00 horas } \\
\hline \multicolumn{5}{|c|}{ Documentação } \\
\hline \multicolumn{4}{|c|}{ Código } & Tipo \\
\hline \multicolumn{4}{|c|}{ Doc 01_Caso1_Telas_das_Campanhas } & PDF \\
\hline \multicolumn{4}{|c|}{ Doc 02_Caso1_E-mails de acompanhamento } & PDF \\
\hline \multicolumn{4}{|c|}{ Doc 03_Caso1_divulgacao_organizadores } & PDF \\
\hline
\end{tabular}

Fonte: A Autora.

\section{a) Caso 2 - Charity:Water}

Para o caso da Charity:Water, seguiu-se o mesmo padrão de amostragem de entrevistados da plataforma Eventos do Bem. Realizou-se uma busca no banco de campanhas da plataforma, e mais de 120 organizadores de campanhas de aniversário na plataforma foram contatados por mídias sociais (Facebook, Linkedin ou Twitter), nas quais se apresentou o caso desta pesquisa, questões e objetivos, com um convite para responderem à entrevista. Das 120 pessoas 
contatadas, por convergência de disponibilidade e qualidade das campanhas, foram selecionadas 20 pessoas.

Marcaram-se entrevistas presenciais e por Skype, todas realizadas na língua inglesa.

A No Quadro 4, a descrição com a relação dos entrevistados.

Quadro 4 - Entrevistas e documentos do Caso 2: Charity:Water

\begin{tabular}{|c|c|c|c|c|}
\hline Entrevistado & Meio & Gravação & Duração & $\begin{array}{l}\text { Status da campanha } \\
\text { quanto ao Ticket Médio }\end{array}$ \\
\hline C2_E1 & Skype & Sim & $00: 33: 56$ & acima do TM \\
\hline $\mathrm{C} 2 \mathrm{E} 2$ & Skype & Sim & 00:30:09 & acima do TM \\
\hline C2_E3 & Skype & Sim & $00: 42: 28$ & bem acima do TM \\
\hline C2_E4 & Skype & Sim & $00: 46: 08$ & bem acima do TM \\
\hline C2_E5 & Skype & Sim & $00: 23: 33$ & acima do TM \\
\hline $\mathrm{C} 2 \mathrm{E} 6$ & Skype & Sim & 00:36:41 & bem acima do TM \\
\hline $\mathrm{C} 2 \mathrm{E} 7$ & Skype & Sim & $00: 17: 41$ & bem acima do TM \\
\hline C2_E8 & Skype & Sim & $00: 29: 42$ & acima do TM \\
\hline C2_E9 & Skype & Sim & $00: 56: 40$ & acima do TM \\
\hline C2_E10 & Skype & Sim & $00: 28: 30$ & acima do TM \\
\hline C2_E11 & Skype & Sim & $00: 16: 57$ & abaixo do TM \\
\hline C2_E12 & Skype & Sim & $00: 27: 38$ & abaixo do TM \\
\hline C2_E13 & Skype & Sim & $00: 15: 37$ & abaixo do TM \\
\hline C2_E14 & Skype & Sim & $00: 31: 50$ & abaixo do TM \\
\hline C2_E15 & Skype & Sim & $00: 30: 56$ & abaixo do TM \\
\hline C2_E16 & Skype & Sim & $00: 44: 30$ & abaixo do TM \\
\hline C2_E17 & Skype & Sim & $00: 38: 10$ & abaixo do TM \\
\hline C2_E18 & Skype & Sim & $00: 27: 00$ & abaixo do TM \\
\hline C2_E19 & Skype & Sim & $00: 21: 48$ & abaixo do TM \\
\hline C2_E20 & Skype & Sim & 00:30:29 & abaixo do TM \\
\hline \multicolumn{5}{|c|}{20 pessoas entrevistadas no total de 10:42:09 horas } \\
\hline \multicolumn{5}{|c|}{ Documentação } \\
\hline \multicolumn{4}{|c|}{ Código } & Tipo \\
\hline \multicolumn{4}{|c|}{ Doc 01_Caso2_Telas_das_Campanhas } & PDF \\
\hline \multicolumn{4}{|c|}{ Doc 02_Caso2_E-mails de acompanhamento } & PDF \\
\hline \multicolumn{4}{|c|}{ Doc 03_Caso2_divulgacao_organizadores } & PDF \\
\hline
\end{tabular}

Fonte: A Autora.

Além dos Organizadores das campanhas, também foram entrevistados os funcionários da plataforma Charity:Water. Desta forma, foram entrevistados 6 funcionários do Charity:Water cuja descrição compõe o Quadro 5. 
Quadro 5 - Entrevistas com funcionários da Charity:Water

\begin{tabular}{|c|c|c|c|c|}
\hline Entrevistado & Meio & Gravação & Duração & Cargo \\
\hline F1 & Skype & $\operatorname{sim}$ & $00: 34: 45$ & $\begin{array}{c}\text { Analista } \\
\text { Financeiro }\end{array}$ \\
\hline $\mathrm{F} 2$ & Skype & $\operatorname{sim}$ & $00: 27: 32$ & $\begin{array}{c}\mathrm{COO}-\text { Chief } \\
\text { Executive Oficer }\end{array}$ \\
\hline F3 & Presencial & não & 00:22:00 & $\begin{array}{l}\text { Diretora de } \\
\text { Comunicações } \\
\end{array}$ \\
\hline F4 & Skype & $\operatorname{sim}$ & $00: 58: 37$ & $\begin{array}{l}\text { Vice Presidente } \\
\text { de relações chave }\end{array}$ \\
\hline F5 e F6 & Presencial & $\operatorname{sim}$ & $00: 54: 21$ & $\begin{array}{l}\text { F5 e F6- } \\
\text { Especialistas de } \\
\text { Experiência do } \\
\text { usuário. }\end{array}$ \\
\hline F7 & Presencial & não & $00: 45: 00$ & Designer \\
\hline \multicolumn{5}{|c|}{6 pessoas entrevistadas no total de $4: 02: 15$ horas } \\
\hline \multicolumn{5}{|c|}{ Documentação } \\
\hline \multicolumn{4}{|c|}{ Código } & Tipo \\
\hline \multicolumn{4}{|c|}{ Doc_01_Caso2_Relatorios_2008_2015 } & PDF \\
\hline \multicolumn{4}{|c|}{ Doc_02_Caso2_Entrevista_HistóriaCW_Scott } & MP4 \\
\hline
\end{tabular}

Fonte: A Autora.

\subsubsection{Modelo de Análise de dados}

Considerando-se as várias técnicas relevantes para a análise dos resultados neste estudo de caso múltiplo, optou-se pela estratégia da síntese cross-case. A análise cross-case busca comparar padrões emergentes de casos analisados, possibilitando ir além das impressões iniciais, especialmente por perspectivas diferentes sobre os dados. Essas táticas aumentam a probabilidade de uma teoria acurada e confiável (EISENHARDT, 1989).

Para isso, a análise de dados foi desenvolvida em duas etapas. Em primeiro lugar, analisou-se cada caso separadamente, para garantir o aprofundamento e a compreensão dos fatores identificados, possibilitando a emergência de padrões únicos e uma análise apurada de cada abordagem. Em segundo lugar, cruzaram-se os dados almejando identificar padrões comuns e 
categorias únicas para orientar a resposta à questão de pesquisa.

Para garantir o aprofundamento e qualidade da coleta dos dados, seguiram-se as diretrizes de análise de conteúdo elaboradas por Bardin (2006). Tal abordagem pode ser definida como um conjunto de técnicas de análise de comunicação que, pela aplicação de procedimentos sistemáticos e objetivos da descrição de conteúdo das mensagens elaboram indicadores que permitam a inferência de conhecimentos por meio da interpretação de dados orientada por rigor científico.

Assim, para a análise dos dados foram seguidas as fases da análise de conteúdo discriminadas por Bardin (2006) como: 1) pré-análise de conteúdo; 2) exploração do material; 3) tratamento dos resultados, inferência e interpretação.

\subsubsection{Pré-análise de conteúdo}

A pré-análise de conteúdo consiste na organização da documentação a ser abordada na análise e pela leitura prévia da documentação, denominada "leitura flutuante" (BARDIN, 2006).

Segundo Flick (2009), a diversidade de tipos de material documentado incluindo imagens e áudios - tem relevância no processo de pesquisa em vista de obter-se uma análise aprofundada. Logo, seguindo o critério de exaustão na exploração de documentos pertinentes e com representatividade para o tema de pesquisa referente às campanhas de angariação P2P (BARDIN, 2006), o corpus documental consistiu nas transcrições de entrevistas, bibliografia, notas pessoais, documentos, relatórios afins e também recursos de imagem como vídeos, fotografias e o layout de cada página de campanha digital estudada.

Selecionado o material a ser analisado, procedeu-se às leituras flutuantes de todo o material, com o objetivo de contextualizar, obter uma compreensão global do funcionamento das plataformas e dinâmica e interação de campanhas de angariação, fluxo de usuário, os textos relacionados, vídeos, interfaces.

Partindo-se de recortes de texto nos documentos de análise foram sistematizados e rascunhados aspectos e categorias visando a uma análise 
posterior mais aprofundada.

\subsubsection{Exploração do material}

Nessa etapa fez-se uma descrição analítica, orientada por um estudo aprofundado com base no referencial teórico e proposições desta pesquisa, análise do material coletado e procedeu-se à codificação. De acordo com Bardin (2006), a codificação consiste na transformação de dados brutos do texto num agrupamento lógico orientado pela agregação e enumeração de categorias, para representar o conteúdo abordado.

Para realizar a codificação, a autora definiu que os dados brutos recolhidos do material deveriam ser transformados, por meio de recortes, agregação e enumeração, num conteúdo representativo, passível de esclarecer o analista acerca das características do texto que podem orientar sua análise pelos índices elaborados.

\subsubsection{Tratamento dos resultados, inferência e interpretação}

Nesta fase condensaram-se informações para análise, culminando em interpretações inferenciais. Segundo Bardin (2006), este é o momento da intuição, da análise reflexiva e crítica.

Mediante cuidadosa apuração e associação, foram identificadas as unidades influenciadoras das campanhas as quais demonstraram ser provenientes de certas categorias de análise. Da emergência das categorias de análise e a identificação de correlações e intensidades específicas das unidades que compõem as campanhas, foram elaborados os Quadros 8, 9 e 10 (apresentados Capítulo 5, item 5.1 desta dissertação) compondo os índices pelos quais guiou-se a análise e comparação dos casos.

Logo, os Quadros 8, 9 e 10 foram elaborados de forma a classificar as unidades de registro com a utilização de uma frequência ponderada apontada por Bardin (2006). Na frequência ponderada pontuaram-se as unidades de registro segundo o seu grau de intensidade no que tange à influência no sucesso das 
campanhas de angariação.

Portanto, para a inferência, cada campanha foi analisada seguindo os índices emergentes dos Quadros 8, 9 e 10 elaborados, resultando num quadro geral analítico das campanhas de angariação estudadas em cada caso. Tais quadros proporcionaram o enriquecimento e aprofundamento da análise ao contrastar as campanhas de cada caso em separado, oferecendo também insumo para a posterior realização do cross-case

Na elaboração das conclusões, foram revisados os padrões emergentes, as tabelas e material resultante da coleta de dados. Com o material resultante da apuração e a coleta de dados foi possível verificar-se que novos fatores e proposições emergiram de modo cada vez mais explícito, possibilitando complementar, aprofundar e contrapor com aspectos levantados modelo de proposições apresentado inicialmente na pesquisa.

Desta forma, considerando o delinemanto da pesquisa apresentado no presente capítulo, a qualidade deste estudo pode ser analisada segundo os testes lógicos apontados por Yin (1994) para qualificar a validade e qualidade de um estudo de caso sendo estes: (a) a validade da construção, (b) a validade interna, (c) a validade externa e (d) a confiabilidade dos dados.

A validade da construção deste estudo dá-se pela triangulação, ou seja, a utilização de múltiplas fontes de evidência - documentos, entrevistas - de maneira que foram traçadas linhas convergentes de investigação. E pela revisão dos correspondentes das entrevistas, para os quais foram enviadas as transcrições para análise dos entrevistados a fim de viabilizar eventuais correções.

Para garantir a validade interna, abordaram-se as táticas analíticas de combinação e comparação de padrões (sua coincidência fortalece a validade interna) e tratamentos de explanações rivais a fim de fortalecer e testar os resultados obtidos.

Quanto à validade externa, segundo Yin (1994, p.31), num método de generalização analítico, "uma teoria desenvolvida previamente é utilizada como um template com que se irão comparar os resultados empíricos do estudo de caso". Considerando-se a característica desta pesquisa como um estudo de caso múltiplo, a lógica de replicação foi considerada desde seu início. 
Por fim, em relação à confiabilidade Gil (2012, p.68) afirma que consiste praticamente em tornar mais operacionais as etapas do processo e conduzir a pesquisa "como se alguém estivesse olhando sobre seu ombro."

Yin (1994) complementa que a confiabilidade se prova quando as operações realizadas no estudo podem ser repetidas com sucesso. Para tanto foram desenvolvidos os documentos de protocolo do estudo de caso, relatórios e uma base de dados para ele, em que se organizaram os dados obtidos em cada caso, as anotações e análises executadas e relatórios elaborados. 


\section{APRESENTAÇÃO DOS RESULTADOS}

Neste capítulo são apresentados o estudo sobre os empreendimentos Eventos do Bem e Charity:Water bem como os resultados da coleta de dados realizada. Esses dados foram apurados com base nas entrevistas e documentação relativa aos casos, logo são permeados por citações e aspectos sobre as páginas da plataforma e/ou experiência da equipe e organizadores na mobilização das campanhas.

Em vista disso, a estrutura seguida consiste na contextualização de cada plataforma web na cultura de doação do respectivo país de origem, histórico de criação e desenvolvimento de cada empreendimento, apresentação e descrição da jornada de experiência dos usuários nas campanhas online, seguida pela apresentação das experiências de organizadores e da equipe de funcionários sobre a promoção das campanhas $\mathrm{P} 2 \mathrm{P}$.

\subsection{Estudo de Caso 1: Eventos do Bem}

\subsubsection{Cultura de doação no Brasil}

Contrastando o fato de ser a $7 .^{\mathrm{a}}$ economia mundial com sua posição de 68. ${ }^{\circ}$ lugar no World Giving Index (CAF, 2016) - relatório que faz a classificação de solidariedade entre 140 países - é possível concluir que a cultura de doação brasileira ainda é pouco desenvolvida.

Em 2015, foi realizada uma pesquisa pelo Instituto para o Desenvolvimento do Investimento Social (IDIS) que possibilitou um conhecimento maior sobre o doador pessoa física brasileiro, suas motivações e características para doar. A pesquisa indicou que $52 \%$ dos brasileiros já doaram financeiramente pelo menos uma vez em 2015, totalizando o mercado de doações 
de pessoas físicas para OSCs como de 13,7 bilhões (IDIS, 2015).

Segundo Paula Fabiani - Diretora-Presidente do IDIS - o montante doado por pessoas físicas é uma boa surpresa, "supera de longe o último levantamento do Benchmark do Investimento Social Corporativo (BISC), que totalizou o investimento social realizado pelas 350 maiores empresas do Brasil em R\$ 2,3 bilhões, em 2014” (IDIS, 2015, pág. 10). Os mais de R\$ 13 bilhões doados representam 0,23\% do PIB brasileiro. Esses dados demonstram que o fomento à doação por parte de indivíduos é um campo vasto e com potencial de crescimento.

Nesse contexto, o mercado de serviços relacionado à captação de recursos vem crescendo nos últimos anos, podendo-se identificar o desenvolvimento de várias iniciativas relativas à inovação em captação de recursos que utilizam a tecnologia para auxiliar as OSCs brasileiras com novos produtos e serviços.

Utilizando-se a classificação apontada pelo Relatório da Fundação Kelogg (2000) - presente no item 2.4.1 desta dissertação - é possível identificar algumas das Social Good Networks brasileiras, que atuam em diversas áreas como: (1) e-commerce, por meio de empresas como o Pólen; (2) portais de voluntariado, das quais se destaca o portal Atados; (3) portais de doação, nos quais estão as plataformas de crowdfunding para OSCs - como a Juntos.vc e Benfeitoria - e a captação de recursos por P2P, protagonizada pela empresa Eventos do Bem.

\subsubsection{Histórico da startup Eventos do Bem}

Conforme apresentado no relato da experiência - Capítulo 1 desta dissertação - a startup Eventos do Bem surgiu da necessidade e desafios de efilantropia vivenciados na atuação profissional da autora no terceiro setor.

Considerando ser uma startup de tecnologia, e o orçamento financeiro restrito dos sócios, a empresa desde seu início contou com a atuação dos próprios fundadores programadores, trabalhando no desenvolvimento de toda a 
plataforma, concepção, design e estratégia de crescimento.

Ainda no início do processo, os empreendedores foram selecionados para participar de alguns programas de capacitação em gestão e desenvolvimento de startups: O Lab Social Good Brasil e o Boost Camp promovido pela Universidade de Santa Clara (EUA).

Os programas referidos são especializados em startups sociais, dessa forma, os empreendedores foram capacitados com conhecimentos gerais de empreendedorismo - como estratégias de Design Thinking, e abordagem Lean Start $U p$ - e metodologia especificamente desenvolvida para auxiliar empresas sociais. Nesses programas, os empreendedores se familiarizaram com o conceito de negócio social e seu específico modelo de geração de valor.

Os negócios sociais são modelos híbridos de empresas que possuem desde sua origem a intenção de gerar impacto social e lucro concomitantemente (COMINI; OLIVEIRA FILHO; KYAMA, 2012). Essa modalidade apresenta o duplo desafio de a empresa ser lucrativa e se manter fiel à sua missão social de forma que esses objetivos não se tornem rivais, mas complementem-se, garantindo a sustentabilidade do empreendimento.

Além disso, é notável quão recente e pouco conhecido é o modelo no Brasil. Em algumas das reuniões de potenciais parcerias, a startup vivenciou dificuldades de compreensão tanto por parte de empresas quanto das organizações do terceiro setor, que não compreendiam a compatibilidade de geração lucro e impacto social da startup.

Todavia foi interessante verificar que a incompreensão do modelo de negócio social ocorreu principalmente em empresas e OSCs mais tradicionais. No contato com empresas de tecnologia, com cultura de inovação, verificou-se grande empatia e aceitação do conceito, resultando em algumas parcerias com multinacionais que apoiaram o desenvolvimento da plataforma Eventos do Bem com recursos, mentoria estratégica e divulgação na rede de contatos.

No desenvolvimento do software de angariação P2P, a fim de validar o produto no mercado, foram adotados os princípios da Lean Startup de desenvolvimento e validação ágil (RIES, 2012). Foi lançada previamente uma 
versão básica, com as funcionalidades necessárias para a validação da hipótese do produto e, durante todo o processo, pessoas que criaram campanhas $\mathrm{P} 2 \mathrm{P}-$ que chamaremos de organizadores - e doadores das campanhas realizadas eram contatados de modo que a equipe obtivesse respostas de melhoria e novas funcionalidades para a plataforma.

Como relatado, apesar da grande aceitação inicial com a criação de campanhas dos mais diversos temas e popularização da ideia, a necessidade de assessoria dos organizadores tornou-se cada vez mais evidente: as pessoas não sabiam como divulgar suas campanhas com eficiência e, devido à novidade da ferramenta, foram suscitadas questões relativas às melhores práticas para a mobilização das campanhas.

\subsubsection{A plataforma Eventos do Bem}

Após os primeiros testes de criação de campanhas manualmente em sites de três OSCs, a plataforma Eventos do Bem foi desenvolvida em 2015 . $\mathrm{Na}$ época, a referência para a equipe foram as plataformas de crowdfunding e, devido a isso, o layout foi inspirado na estrutura presente em plataformas famosas nesse tipo de técnica como na Kickstarter.com, e na brasileira Catarse.me.

Desde seu início, a plataforma tem o cadastro para OSCs fechado, isto é, submetido à aprovação da equipe, a fim de garantir qualidade e legitimidade das causas. As seleções das OSCs são baseadas nos pilares de transparência na aplicação dos recursos, impacto social realizado, estrutura de gestão na administração dos recursos e histórico de solidez no terceiro setor. Esses pilares são provenientes do conhecimento adquirido com a experiência de um dos sócios de atuar com investimento de impacto social.

Após montada uma base mínima de OSCs no portfólio, foi testada a geração de campanhas $\mathrm{P} 2 \mathrm{P}$ na plataforma. No processo foi possível observar fatores influenciadores, melhorias e novas funcionalidades para $\mathrm{o}$ desenvolvimento da tecnologia $\mathrm{P} 2 \mathrm{P}$, pensando também em ferramentas de 
interação da organização e seus apoiadores.

\subsubsection{A jornada de interação dos usuários nas campanhas de angariação}

A fim de compreender a experiência do usuário ao interagir com a angariação P2P, serão apresentados os fluxos de mobilização de campanhas e doação online mediada pela plataforma. Em conjunto serão apresentados pontos relevantes citados nas entrevistas e apuração documental.

- Jornada do usuário-organizador na mobilização de sua campanha pela plataforma Eventos do Bem

Figura 12 - Eventos do Bem: fluxo do organizador da campanha eventos 0 do bem

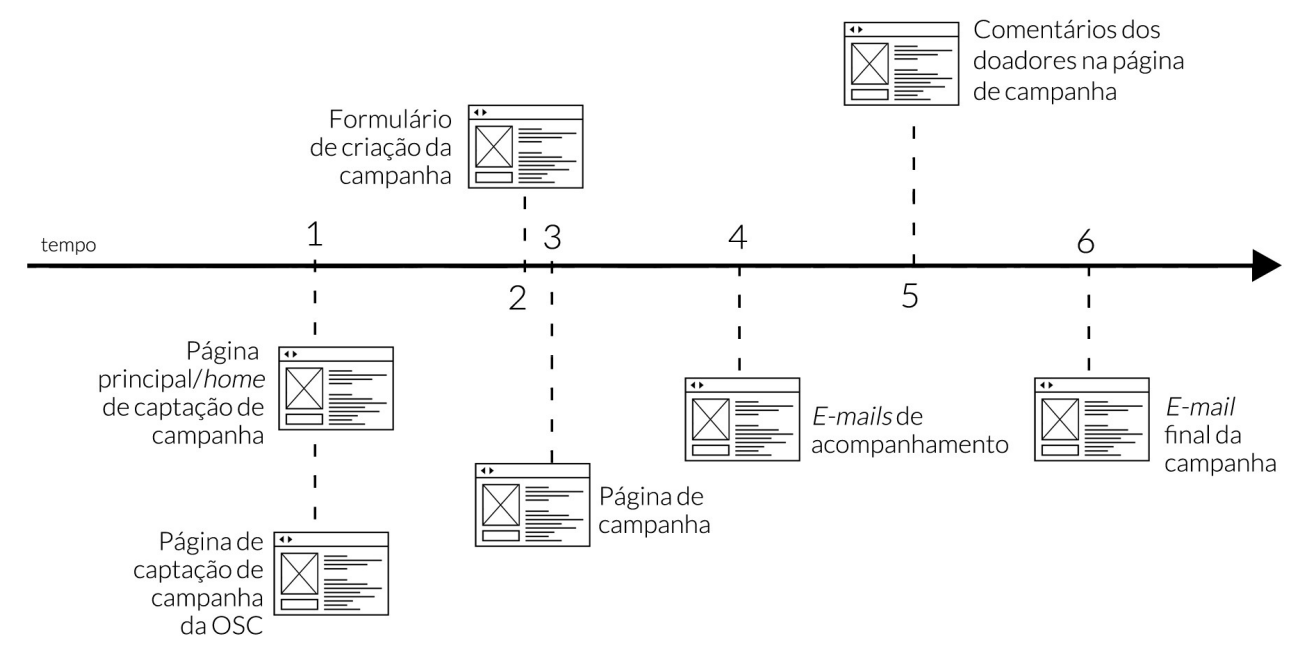

Fonte: A Autora.

1) Página principal e página de captação da OSC 
Além de apresentar botões e discurso convidando o usuário para criar uma campanha de angariação P2P para uma OSC de sua escolha desde sua página principal, por ser uma plataforma que tem como proposta ser utilizada por diversas entidades, para cada organização social cadastrada foi disponibilizada uma página de captação de campanhas.

Assim, cada OSC ganha um link personalizado e página online pela qual pode mobilizar e direcionar sua rede de contatos a criar campanhas diretamente para a organização.

Esta página pode ser personalizada com foto de capa e de perfil da organização; possui um espaço no qual ela conta um pouco mais de sua história, seu impacto social, disponibiliza se quiser alguma mídia - fotografia ou vídeo em que informa sua missão e termina apresentando valores de angariação tangíveis em algum impacto social específico.

Logo, todas as campanhas criadas a partir da página da OSC direcionam a angariação para a respectiva entidade. Essas páginas são divulgadas pela OSC em sua rede de contatos por meio de mailing, Facebook ou implementação de botão de direcionamento em seu próprio website.

\section{2) Formulário de criação da campanha}

O formulário de criação da campanha possui alguns campos para serem completados pelo criador como:

(a) o nome da campanha pelo qual será criado link personalizado;

(b) seleção da OSC que a pessoa escolheu ajudar na lista de entidades apresentada;

(c) categoria da campanha, podendo selecionar entre um aniversário, evento esportivo, casamento ou outro evento criativo;

(d) meta de angariação, que também poderia ser desativada;

(e) data de finalização da campanha;

(f) fotografia do criador da campanha; 
(g) fotografia da causa social apoiada;

(h) espaço para a pessoa escrever um texto personalizado para motivar sua rede de contatos a apoiar sua campanha;

(i)

(j) espaço para link de vídeo integrado das plataformas de audiovisual Youtube ou Vimeo, possibilitando que o usuário personalize sua página de campanha com os vídeos que preferir.

Importante frisar que em cada campo é ativada uma caixa de orientações na qual o usuário era aconselhado a colocar uma meta em sua campanha, delimitar um prazo de no mínimo 30 dias de duração, criar a campanha com antecedência de seu aniversário - caso esta fosse a categoria escolhida personalizar o máximo que pudesse seu texto, vídeo e fotografias de campanha. Após preencher os campos do formulário de criação, a campanha de angariação é automaticamente criada e a pessoa já pode divulgar para sua rede de contatos.

Todos os organizadores entrevistados para esta pesquisa afirmaram ter facilidade de criar a campanha, sem terem sentido dúvidas ou encontrado maiores problemas.

\section{3) A página de campanha}

Como unidade de análise desta pesquisa, a seguir será apresentada a página da campanha na qual foram destacados elementos que interferem em sua dinâmica. Estes elementos estão identificados na Figura 13 por itens colocados em ordem alfabética, os quais serão aprofundados em separado a fim de explicitar características e interações de cada elemento com seus stakeholders. Importante ressaltar que, apesar de aparência idêntica à página original, o conteúdo da Figura 13 é meramente ilustrativo 
Figura 13- Eventos do Bem: Página de campanha

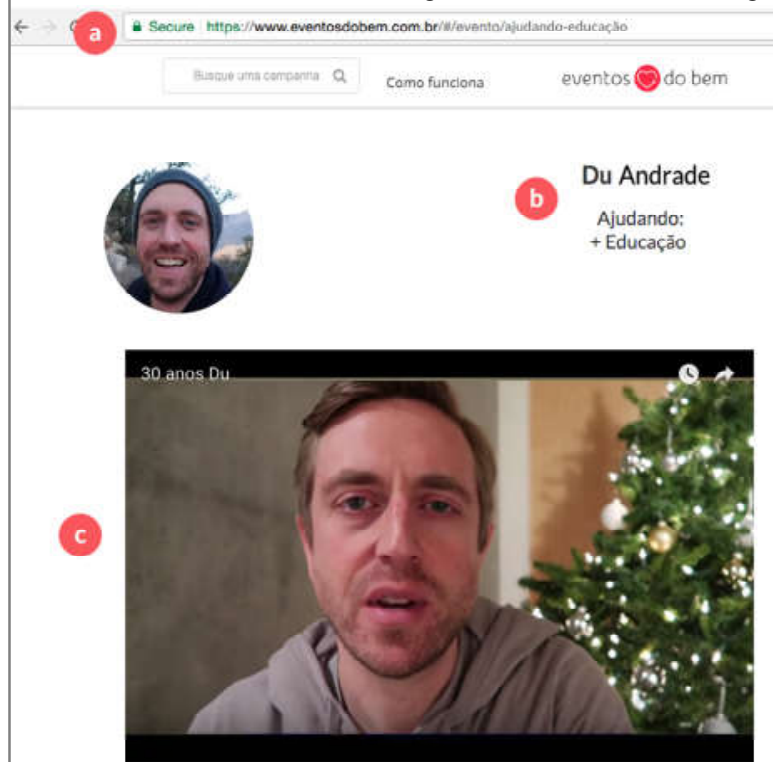

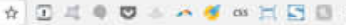
Comece seu evento

Olà pessoas queridas:

Dia 10 de agosto farei 30 anost Sim, tudo isso, rsss...

Resolvi fazer algo diferente para comemorar essa data especial. Estou conectando meu aniversario com uma causa que acredito e estou super dedicado - a melhora na educaçăo dos bresileirinhos.

Assim, quem quiser me dar algo, ao invés de presentes (o apartamento é pequeno

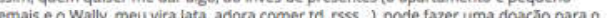
projeto + Educação.

A doação vai diretamente para pagar o almoço das 64 crianças carentes que recebemos no projeto. No + Educą̧ăa as crianç̧as de 7 a 11 anos têm atividades de Comunicar (português), Pensar (matemática) e Brincar (brincar mesmo, rs).

Năo se preocupe pois a ONG é muito sêrila e auditada pela Deloitte.

Pode compartihar com quem quiser! Quanto mais gente envolvida, melhor!

Com R\$ 25,00 você paga o almoço de uma criança por uma semana. Com Rs 100,00 vocé paga o almoşo de uma criança por um mes. Com RS $1.000,00$ vocé paga o almoço de uma criança para o ano inteirof (ficamos 2 meses de ferlias...t. Voce pode presentear com

Super obrigadão e vamos com tudo methorar a educaçăo de nosso pais!

bis :)

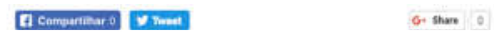

Todas as doaçōes para Du Pacifico

Nome Comentário

Marcos Parabéns Dudu do Acaraú pela aça U uma honra colaborar

Clesar be Cliear logo abaixo me traz uma sensaçăo de harmonia conforto e paz no

Ardrade coraçăo. Estou muito feliz por vocés fazerem um trabalho digno.

Mateus Excelente iniciatival "Seja a mudança que woce quer ver no mundo:"

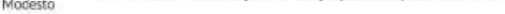

e

Carolina Linda açăo Dudul Espero que esse gesto gere frutos incrive:s

Carmen Du, Parabens pela iniciativa bo

Fúlvia Parabêns amigo, duplamentel Pelos 30 e pela iniciariva:

Leite

Bruno Simplesmente sou fầ e ainda quero aprender com e me inspirar nas suas Sexas Iniciativas!! Bravolle Doaçăo para uma criança el acompanhante :) Abraço:

Fábio Feliz aniversário Dudum! Multa saúde e alegrias na sua vida e que ve sempre Guimarles possa continusr fozendo o bem i) Seu trabalho está mudando a vida de muita gente. Conte sempre comigo, Grande abräç, Fabinho

Miriam Parabèns meu querido, vcé muito especiallill fique tranquilo que vc nâo parece que vai fazer 30

Natalia Dudu, Murto legal sua iniciariva de desapegar de bens materiais e doar para as

Crinclas. Yenho muto orgulto de ves investirem tanto ves est to

azendo um bem incrivel fue o va estramos muto telizes em pader ajudar. Feliz aniversario $1 \mathrm{~B}$

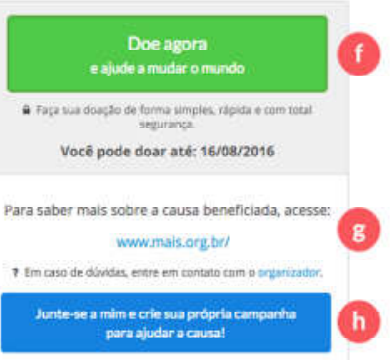


A seguir serão abordados os itens destacados na Figura 13, a fim de aprofundar sua influência na dinâmica da campanha sob a perspectiva de uma melhor performance financeira.

\section{a) Sistema de segurança e personalização da URL}

Por ser uma plataforma de transação financeira, para garantir a segurança de dados, foi implementado o certificado SSL - Secure Socket Layer. Esse certificado é um padrão global em segurança: os dados são criptografados comunicando segurança e legitimidade aos usuários.

O endereço do site também é customizado com o nome que o organizador deu à sua campanha, aumentando a referência pessoal quando o link for compartilhado nos canais de comunicação.

\section{b) Cabeçalho da campanha}

Como identificação e apresentação da campanha, optou-se por colocar o nome seguido da organização social apoiada. Importante verificar que o nome do organizador é destacado devido justamente ao fato de a proposta da campanha $\mathrm{P} 2 \mathrm{P}$ enfocar mais o indivíduo como protagonista. Optou-se por isso, pois a premissa considerada foi a de que a rede de contatos veio pela pessoa física e principalmente motivada por ela a doar; neste primeiro momento, a causa social tem papel secundário até se assegurar um relacionamento maior.

Caso o criador da campanha opte por não colocar sua fotografia, imagens- padrão da causa social são colocadas no lugar.

\section{c) Vídeo da campanha}

Os criadores da campanha poderiam optar por colocar o vídeo-padrão da causa apoiada, um outro vídeo selecionado à sua escolha, ou até mesmo elaborado por ele próprio. $15 \%$ dos entrevistados ( C1_E5, C1_E7, C1_E8) fizeram vídeo, dos quais se destaca o organizador C1_E7 que elaborou vários vídeos criativos com os quais lembra sua rede sobre a sua campanha de aniversário.

\section{d) Texto de proposta da campanha}


O organizador pode escolher se deseja colocar o texto-padrão da OSC - que contém somente a missão dela - ou elaborar um texto próprio. Entre os entrevistados, todos alteraram o texto de sua campanha, pois o texto-padrão somente apresentar a missão da OSC.

Com o auxílio da equipe da plataforma, os organizadores foram orientados a seguir o modelo de texto para (a) apresentar a proposta da campanha ligando ao evento pessoal da vida do organizador, (b) apresentar brevemente a causa e o impacto,

(c) fazer o pedido com sugestões de valores sobre os quais foram aconselhados 150, 100, 50 reais, (d) terminar relembrando o impacto, convidando diretamente o leitor a doar.

A maioria dos organizadores seguiram as orientações, adaptando-as com fatores pessoais. Alguns propuseram recompensas simbólicas ao alcançarem algumas metas de captação da campanha - como fazer um jantar especial para os apoiadores e cumprir desafios pessoais, outros apresentaram mais a OSC e abordaram outros fatores, garantiram a legitimidade da organização ou disponibilizaram outros links para que sua rede conhecesse mais sobre a entidade.

\section{e) Comentários da campanha}

Com a possibilidade de doar e deixar um comentário para o organizador, a ferramenta foi bastante utilizada nas campanhas. Todas as campanhas obtiveram mensagens deixadas pelos apoiadores. As pessoas deixavam comentários de cumprimentos pela iniciativa e encorajando a campanha a ganhar força. O organizador C1_E6 comentou ser um dos fatores de que mais gostava e que o mantinha acessando suas páginas de angariação diariamente.

\section{f) Botão de doação}

O botão de doação foi elaborado com uma cor contrastante do restante do layout; além disso, o texto com o verbo no imperativo convidava a pessoa a doar e a ajudar a "mudar o mundo", estimulando o apoiador a transcender o significado do ato para além do fato de presentear seu conhecido. Logo abaixo, um lembrete da segurança de transação dos dados e a data máxima em que a 
campanha estará ativa.

\section{g) Mais informações sobre a causa}

É disponibilizado um link redirecionando ao site oficial da causa, com mais informações sobre ela ou a possibilidade de o usuário pedir mais informações para o próprio organizador da campanha, cujo e-mail é disponibilizado para contato.

Sobre isso, alguns dos organizadores (C1_E2, C1_E8) contaram que houve pessoas desconfiadas sobre a legitimidade da causa e se o dinheiro iria realmente para ela. Os entrevistados que foram questionados por seus apoiadores sobre esse quesito elaboraram sua própria solução comprometendo-se a efetivar a visita à OSC apoiada com alguns de seus doadores.

\section{h) Botão convidando o usuário a fazer a mesma ação, a de criar uma campanha para a causa.}

Com inspiração de sites de angariação P2P online que atuam com "times" de captação de recursos - por exemplo, o crowdrise.com - sob a liderança de alguns organizadores, foi disponibilizado um botão convidando o usuário a criar uma campanha para aquela mesma causa e seguir o exemplo de seu conhecido.

Foi possível verificar o resultado dessa mecânica nos próprios entrevistados. Entre eles, o C1_E4 inspirou o C1_E3 a criar sua campanha de aniversário também, que, por sua vez, inspirou o C1_E9. Esse fato exemplifica o potencial de campanhas inspirarem outras.

\section{i) O layout da campanha}

Em relação ao layout, que pode ser observado na Figura 13, optou-se por essa disposição devido ao benchmarking ter sido de websites de crowdfunding, o conceito mais próximo do $\mathrm{P} 2 \mathrm{P}$ pelo qual os desenvolvedores se orientaram na época, logo, nota-se o modelo similar no qual existe o destaque grande para o vídeo no topo, botão de doação com termômetro de angariação na extrema direita e texto explicativo da campanha logo abaixo. 
Os entrevistados apontaram algumas questões relativas ao layout da campanha como a melhoria do seu design, considerado pouco atrativo (C1_E7, C1_E8, C1_E17), e a necessidade de ele se adaptar a outros aparelhos eletrônicos como os celulares (C1_E4, C1_E9).

- Jornada do usuário-doador na mobilização de sua campanha pela plataforma Eventos do Bem:

Outro aspecto que compõe a experiência de campanhas, relacionado diretamente ao seu sucesso, é o checkout no qual o usuário opta por efetuar a doação no website. Considerando a cultura de compras virtuais ser recente no Brasil, este é um processo crítico para o sucesso das campanhas.

Figura 14 - Eventos do Bem: fluxo do doador da campanha eventos do bem

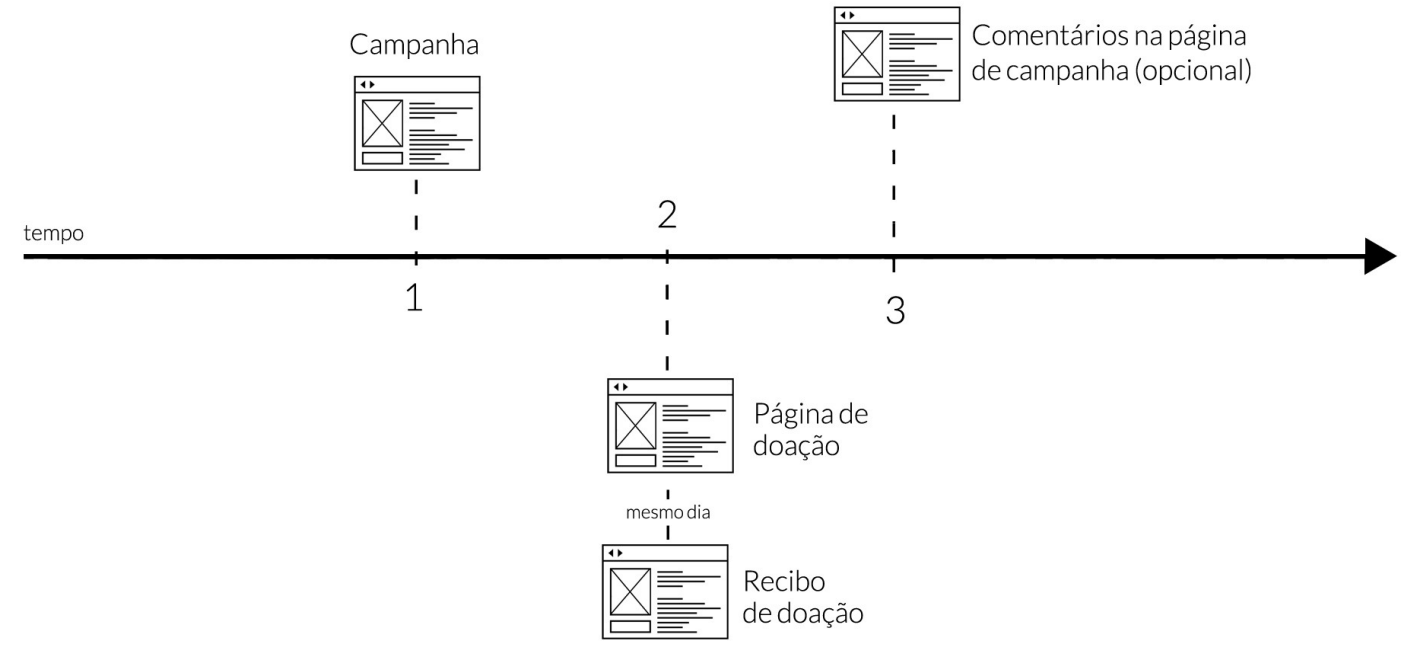

Fonte: A Autora.

\section{1) Página de Campanha}

Conforme explicitado, a página de campanha possui informações que a relacionam ao conhecido do apoiador, traz informações sobre a causa e é possível visualizar os comentários dos últimos doadores da campanha. Existe um botão de doação à extrema direita com a chamada para efetivar a doação. 


\section{2) Página de doação e recibo}

A página de doação pede informações relativas ao nome e e-mail do usuário, valor desejado a apoiar, mensagem para o apoiador, ou a opção de ele ser anônimo. Com relação aos meios de pagamento, a página possui “checkout transparente", isto é, o usuário não é direcionado a uma página de uma empresa externa à plataforma para colocar sua informação bancária, mas pode coloca-la no próprio site. Além do certificado SSL, mencionado, o sistema de pagamentos é integrado com a plataforma IUGU, startup brasileira que garante a segurança de transações financeiras pela internet.

O usuário pode escolher doar por cartão de crédito ou emitir boleto bancário. A flexibilidade do sistema de cartão de crédito possibilitou que a plataforma recebesse doações internacionais dos mais diversos países.

Ao efetivar a doação, o doador recebe de imediato o recibo da transação em seu e-mail cadastrado. No recibo, consta o texto com a informação do nome da campanha de seu amigo, personalizando ainda mais o processo.

Sobre as doações para a campanha, alguns dos entrevistados relataram terem encontrado problemas com a efetivação delas (C1_E2, C1_E15). A equipe da plataforma justifica que essas doações não foram efetivadas devido à falta de fundos ou de aprovação do banco para a utilização do cartão, falta de conhecimento da pessoa de como se realiza uma compra pela internet, ou o erro do doador ao digitar os dados do cartão.

Enquanto muitos desses impasses se deviam à falta de conhecimento das pessoas de como fazer uma compra na internet, outros problemas eram relacionados

com melhorias ou erro no próprio código de programação da plataforma. Por isso o desenvolvimento e melhoria de implementações da página de pagamentos foram constantes e evidenciaram para a equipe a importância dessas providências para o sucesso das campanhas.

\section{3) Comentários na página de campanha}

Muitos doadores efetivam comentários de cumprimentos ao organizador 
que aparecem publicamente na página de campanha. Da relação entre doações e comentários nas páginas de angariação pelos apoiadores, uma média de $68 \%$ comentou e nenhum decidiu doar anonimamente.

\subsubsection{A dinâmica vivenciada pelos usuários-organizadores na promoção das campanhas}

Conforme explicitado no item 3.6.5.1 desta pesquisa, as entrevistas seguiram blocos temáticos. Nas transcrições das entrevistas, percebeu-se que os organizadores fizeram afirmações sobre a dinâmica de realização das campanhas que transcende a interação documentada nas respectivas páginas da plataforma.

\section{a) Dados pessoais, comportamento pró-social e motivações para criar a campanha}

Os organizadores de campanha entrevistados eram da faixa de 20 a 35 anos, cinco homens e 15 mulheres, os quais utilizavam frequentemente suas redes sociais, entre as quais prevalecia a rede Facebook.

Com exceção do C1_E20, todos os organizadores já possuíam histórico de envolvimento com a OSC apoiada: a grande maioria com voluntariado ou conheciam membros da equipe da organização; cinco dos entrevistados já havia efetuado doações financeiras para alguma causa social.

Sobre as razões de terem criado as campanhas de aniversário, os organizadores mencionaram que:

--- ficaram inspirados, por ser uma forma diferente de comemorar seu evento

(C1_E19, C1_E20);

--- queriam ajudar a organização (C1_E1, C1_E2, , C1_E3, C1_E4, C1_E5,

C1_E6, C1_E11, C1_E12, C1_E13, C1_E16, C1_E17, C1_E18, C1_E19);

--- queriam mobilizar sua rede para fazer uma coisa boa (C1_E3, C1_E4, C1_E6, C1_E8, C1_E9, C1_E13);

--- sentiam que não precisavam de nada material como presente, então a campanha era uma boa forma de presenteá-los fazendo algo bom 
(C1_E12, C1_E14, C1_E15);

--- tiveram uma experiência de voluntariado com a organização e queriam ajudar (C1_E9, C1_E12, C1_E14).

\section{b) Assessoria da plataforma}

Todos os entrevistados que optaram por se comunicar com a equipe da plataforma afirmaram terem tido um bom atendimento e acompanhamento; a comunicação foi realizada por diversas mídias sociais e foram atendidos com prontidão. Ademais, um ponto levantado por dois entrevistados (C1_E3, C1_E7) foi que seguiram as dicas de personalização da campanha, orientadas na página de criação, o que os ajudou a guiarem suas campanhas.

Além disso, a assessoria foi importante para também gerar segurança dos organizadores sobre a seriedade da plataforma. Alguns dos organizadores relataram que sentiram um pouco de insegurança para divulgar uma plataforma que não conheciam muito. Sobre isso a entrevistada C1_E15 afirmou "eu estava meio cabreira com relação das pessoas colocarem o dinheiro ali".

Notou-se que alguns dos organizadores (referidos no Quadro 9) optaram por não seguir as dicas e se comunicar com a equipe. Pelas entrevistas, evidenciou-se que a principal razão para isso era falta de tempo e/ou motivação para se engajarem na campanha.

\section{c) Campanhas Criativas}

Houve abordagens que fugiam do modelo de mobilização tradicional realizado pelos criadores das campanhas de aniversário, desde vídeos sobre a proposta de angariação e a causa apoiada pelo organizador C1_E7, até a criação de "recompensas sociais" mobilizadas pelos organizadores C1_E4 e C1_E10.

O organizador C1_E4 colocou "recompensas", caso alcançasse alguns montantes de sua meta de campanha, como pular de asa-delta, fazer jantares para os apoiadores ou levá-los para visitar a OSC apoiada.

Outro entrevistado (C1_E10) fez algo criativo, com um tom cômico: 
elaborou uma série de metas de campanha e divulgou no Facebook, a cada etapa de meta angariada o organizador faria um desafio que consistia em situações engraçadas e encorajadoras para que sua rede de amigos quisesse patrocinar sua campanha.

\section{d) Ações mobilizadas pelo organizador}

Os entrevistados identificaram diversas práticas realizadas na promoção das campanhas. São elas:

(1) enviou mensagem-padrão para a sua rede de contatos em mídias sociais;

(2) enviou mensagem personalizada para cada pessoa de sua rede de contatos;

(3) relembrou com mensagens pessoais seus contatos para efetivarem a doação;

(4) relembrou seus contatos, com mensagens-padrão, sobre sua campanha;

(5) utilizou de múltiplos canais de contato com a rede de apoiadores (com exceção de redes sociais, telefone, ao vivo, pelo aplicativo whats app, entre outros);

(6) propôs visitas à OSC apoiada;

(7) criou material de divulgação como convites para a festa de aniversário divulgando a campanha, vídeos, imagens de lembrete e divulgação nas mídias sociais;

(8) houve comemoração do aniversário e arrecadação na festa;

(9) aplicou uma estratégia previamente definida;

(10) fez abordagens criativas de interação com a rede de contatos;

(11) interagiu com e/ou seguiu alguma das dicas sobre sua campanha de angariação enviadas pela equipe da plataforma. 
Quadro 6 - Eventos do Bem: práticas de divulgação de campanha dos organizadores

\begin{tabular}{|c|c|c|c|c|c|c|c|c|c|c|c|c|}
\hline Código & $\begin{array}{l}\text { Status de } \\
\text { campanha }\end{array}$ & (1) & (2) & (3) & (4) & (5) & (6) & (7) & (8) & (9) & (10) & (11) \\
\hline C1_E1 & bem sucedida & $x$ & & & $x$ & $x$ & & & & & & $x$ \\
\hline C1_E2 & bem sucedida & $x$ & $x$ & $x$ & $x$ & $x$ & $x$ & $x$ & $x$ & & & $x$ \\
\hline C1_E3 & $\begin{array}{c}\text { muito bem } \\
\text { sucedida }\end{array}$ & $x$ & $x$ & $x$ & $x$ & $x$ & $x$ & & & $x$ & & $x$ \\
\hline C1_E4 & $\begin{array}{c}\text { muito bem } \\
\text { sucedida }\end{array}$ & $X$ & $x$ & $x$ & $x$ & $x$ & $x$ & $x$ & $x$ & $X$ & $x$ & $x$ \\
\hline C1_E5 & bem sucedida & $x$ & $x$ & $x$ & $x$ & $x$ & & & & $x$ & & $x$ \\
\hline C1_E6 & bem sucedida & $x$ & $x$ & & & $x$ & $x$ & & & $x$ & & $x$ \\
\hline C1_E7 & $\begin{array}{l}\text { muito bem } \\
\text { sucedida }\end{array}$ & $X$ & $x$ & $x$ & $x$ & $x$ & & $x$ & & $x$ & $x$ & $x$ \\
\hline C1_E8 & bem sucedida & $x$ & & & $x$ & $x$ & $x$ & & $x$ & & & $x$ \\
\hline C1_E9 & $\begin{array}{l}\text { muito bem } \\
\text { sucedida }\end{array}$ & $x$ & $x$ & & $x$ & $x$ & & & & $x$ & & $x$ \\
\hline C1_E10 & bem sucedida & $X$ & & $x$ & $x$ & $x$ & & $x$ & & & $x$ & $x$ \\
\hline C1_E11 & $\begin{array}{c}\text { Abaixo do } \\
\text { ticket médio }\end{array}$ & $X$ & & & & $x$ & & & & & & $x$ \\
\hline C1_E12 & $\begin{array}{c}\text { Abaixo do } \\
\text { ticket médio }\end{array}$ & $X$ & & & & $x$ & & & & & & \\
\hline C1_E13 & $\begin{array}{c}\text { Abaixo do } \\
\text { ticket médio }\end{array}$ & $X$ & & & $X$ & $x$ & & & & & & $X$ \\
\hline C1_E14 & $\begin{array}{c}\text { Abaixo do } \\
\text { ticket médio }\end{array}$ & $x$ & & & & $x$ & & & & & & \\
\hline C1_E15 & $\begin{array}{c}\text { Abaixo do } \\
\text { ticket médio }\end{array}$ & $x$ & & & & $x$ & & & & & & \\
\hline C1_E16 & $\begin{array}{c}\text { Abaixo do } \\
\text { ticket médio }\end{array}$ & $x$ & & & $x$ & $x$ & & & & & & \\
\hline C1_E17 & $\begin{array}{c}\text { Abaixo do } \\
\text { ticket médio }\end{array}$ & $X$ & & & $x$ & $X$ & & $\mathrm{X}$ & & & & \\
\hline C1_E18 & $\begin{array}{c}\text { Abaixo do } \\
\text { ticket médio }\end{array}$ & $X$ & & & & $x$ & & & & & & $x$ \\
\hline C1_E19 & $\begin{array}{c}\text { Abaixo do } \\
\text { ticket médio }\end{array}$ & $X$ & & $X$ & $X$ & $X$ & & & $X$ & & & $x$ \\
\hline C1_E20 & $\begin{array}{l}\text { Abaixo do } \\
\text { ticket médio }\end{array}$ & $x$ & & & $x$ & $x$ & & & $x$ & & & \\
\hline
\end{tabular}

Fonte: A Autora.

\section{e) Reflexões dos usuários-organizadores sobre o resultado e aprendizado que}

\section{obtiveram nas campanhas}

Ao refletirem sobre suas campanhas de angariação, alguns dos entrevistados afirmaram que, no meio dos afazeres de sua vida, não tiveram tempo para se dedicar a divulgar mais sua iniciativa (C1_E1, C1_E10, C1_E9, C1_E12, C1_E14, C1_E15). Outros sentiram vergonha para fazer os pedidos de forma proativa e personalizada para sua rede de contatos (C1_E11, C1_E15).

Ademais, alguns comunicaram que ficaram frustrados com os resultados que obtiveram. Os organizadores C1_E11, C1_E13, C1_17, C1_E19 afirmaram que esperavam um resultado maior de doações de sua rede de contatos, mas admitiram que também não tiveram uma atitude proativa de divulgação. 
Por isso, uma reação frequente em alguns organizadores foi a afirmação de que, se pudessem voltar atrás, fariam de outra forma. Como exemplo, o entrevistado C1_E11 afirma que enviaria mensagens pessoais para cada contato seu, em vez da mensagem massiva que enviou para seus grupos em mídias sociais: "eu percebi que, quando você manda uma mensagem geral, a pessoa não se sente pessoalmente atingida, então facilmente não te responde; ignora mesmo" (C1_E11).

Ao refletir sobre o bom desempenho de sua campanha, o entrevistado C1_E3 destaca ações que considera terem sido efetivas: “eu fiz um lançamento geral na minha página, um post normal pedindo ajuda. Acho que o que foi fundamental é que eu mandei individualmente para praticamente todos os meus contatos. Meu intuito, além de angariar dinheiro para ajudar, era retomar o contato com algumas pessoas. Acho que tem uma coisa social e genuína. Não é uma coisa só de querer o dinheiro da pessoa, mas eu quero que as pessoas participem de uma coisa que é importante para mim. Tiveram umas pessoas que não puderam contribuir, mas que eu retomei o contato. Acho que, para a campanha em si, mandar mensagem pessoal para a pessoa interpelada com uma resposta teve mais retorno. Não foi $100 \%$ de retorno, mas a maioria das pessoas responde e, pelas respostas, eu já ia sentindo quem ia ajudar, quem não podia ajudar e quem manifestava desejo de ajudar."

O entrevistado C1_E6, também bem-sucedido, conta que aprendeu a fazer ações de mobilização a partir do exercício de efetivar sua campanha de aniversário: "Eu recebi doações pequenas, mas de várias pessoas. Acho que foi por isso que a gente conseguiu fazer a meta. Eu divulguei por inbox; eu tinha um controle de quem tinha me respondido, quem tinha doado, quem tinha confirmado que poderia. Essa campanha me deu uma experiência muito legal de como chamar as pessoas para a causa. Gostei muito da experiência na plataforma, porque hoje eu sei chamar as pessoas para as campanhas, porque deu certo".

Outro ponto levantado foi a necessidade que os organizadores sentiram da resposta de impacto social para eles e para sua rede. Alguns entrevistados (C1_E8, C1_E9, C1_E10, C1_E15, C1_E20) comentaram que existia uma 
sensação de desconfiança de o dinheiro realmente ir para a organização e de ele realmente ser utilizado para o fim proposto.

Como a plataforma não possuía a resposta sobre o impacto social como parte do procedimento da campanha online, alguns resolveram essa questão propondo visitar a OSC com alguns apoiadores posteriormente à realização das campanhas (C1_E2, C1_E3, C1_E4, C1_E8), experiência que, segundo C1_E8, fez toda a diferença para finalizar bem sua experiência com campanhas.

Ademais, os entrevistados C1_E3, C1_E4, C1_E6, C1_E9, C1_E12 apontaram outros resultados que foram além da angariação de recursos financeiros. Algumas campanhas geraram voluntários para as organizações sociais apoiadas. Um dos apoiadores da campanha do organizador C1_E6, inclusive, virou coordenador de um dos projetos sociais, e duas parcerias com empresas foram efetivadas por meio dos organizadores e convidados (C1_E3).

\subsubsection{Experiências da plataforma na promoção das campanhas P2P}

Durante o processo de desenvolvimento da plataforma, foi vivenciada uma série de desafios para melhorar a experiência dos usuários e fornecer funcionalidades e ferramentas que ajudassem sua compreensão acerca do funcionamento do novo conceito de angariação P2P, recente no Brasil.

Os organizadores que aceitaram um auxílio mais próximo foram acompanhados por um membro da equipe da plataforma, a quem eram enviadas por $e$ - mail toda semana dicas de mobilização de sua rede de contatos. Essas dicas consistiam em:

a) compartilhar a campanha nas redes sociais;

b) estimular que seus amigos compartilhassem a campanha também;

c) fazer uma lista de amigos e pedir para eles doações para a campanha;

d) compartilhar posts com arte desenvolvida pela própria equipe (as artes consistiam em mensagens e lembretes sobre a própria campanha do organizador).

Durante esse processo, foi requisitado pelos organizadores o fornecimento de material de apoio, que engajasse e educasse sua rede de contatos 
para a causa para qual estava angariando.

Em vista disso, as OSCs cadastradas na plataforma foram contatadas para o fornecimento desse material, no entanto, devido ao despreparo de algumas organizações sociais em elaborar material de qualidade, foi realizada uma parceria com a plataforma Atados para conseguir voluntários que auxiliassem o processo. Foram selecionados cerca de 320 voluntários dessa plataforma, que "adotariam" uma organização, sendo incumbidos de produzir material de divulgação para ela. Em conjunto, devido à falta de conhecimentos básicos em ferramentas digitais, foram feitos vídeos tutoriais orientando ações de utilização da plataforma, boa divulgação das campanhas, auxílio aos organizadores, entre outros.

Com a efetivação das primeiras doações para as campanhas, foi aprendido que, além do acompanhamento para a mobilização da rede, outra ação necessária era a prestação de contas para os criadores de campanhas que queriam saber em tempo real não somente a identidade de quem doou para a sua campanha, mas também o valor, meio de pagamento e data da efetivação dele. Muitos demonstraram desconfiar da plataforma, para mitigar tal sensação, relatórios financeiros eram enviados para o seu e-mail diariamente. Após a fim da campanha, em até 30 dias, o valor era depositado na conta da OSC e um comprovante de transferência enviado ao organizador.

Um ponto importante evidenciado em algumas campanhas foi a incompreensão dos doadores sobre a taxa cobrada pela plataforma ( $9 \%$ dos gastos com a transação de cartão de crédito inclusos) no montante das campanhas. Alguns organizadores (C1_E1, C1_E2, C1_E3) chegaram a comentar que as pessoas muitas vezes preferiam doar com depósito direto na conta da OSC para não terem a taxa abatida e outros preferiam dar em cheque diretamente para o organizador, endereçado à organização.

Mesmo com os organizadores e OSCs compreendendo e apoiando o modelo de negócios, foi perceptível que alguns dos doadores consideravam a taxa um empecilho para efetivar as doações.

Com a experiência da ferramenta de angariação e, depois de se aprofundar sobre os efeitos dela, pela captação de recursos financeiros, também 
foram evidenciados resultados indiretos relativos ao envolvimento social dos participantes.

Dentre os resultados destacam-se:

- Geração de valor das campanhas para as OSCs:

- ativação de novas doações, fora da rede de contatos da OSCs;

- conversão de alguns desses contatos em doadores recorrentes na própria plataforma;

- aumento do engajamento dos próprios organizadores das campanhas que, após a campanha, contataram a equipe e demonstraram interesse de se envolver mais ajudando a OSC a captar mais recursos;

- alguns dos doadores das campanhas chegaram a virar voluntários, coordenadores de projetos e/ou mobilizaram parcerias com as empresas em que trabalhavam.

- Geração de valor da experiência da plataforma para as OSCs:

- desenvolvimento de conhecimentos na área de tecnologia, comunicação de relacionamento, proveniente das necessidades das campanhas;

- a startup intermediou parcerias entre as OSCs e empresas interessadas em utilizarem a ferramenta com proposta de marketing ou como mobilização de funcionários.

\subsection{Estudo de caso 2: Charity:Water}

\subsubsection{A cultura de doação nos EUA}

Posicionado em segundo lugar no relatório World Giving Index (CAF, 2016), os EUA são um dos países com a cultura de doação mais desenvolvida do mundo, significando que os estadunidenses possuem o costume de fazer doações financeiras para as organizações sociais de forma bastante natural e apropriada à seu cotidiano.

Fato comprovado mais especificamente pelo relatório do Giving USA (2017), que aborda a cultura de doação no país, o qual totalizou o montante de cerca de 390 bilhões de dólares em 2016. Na lista das maiores fontes, 80\% desse montante são 
doações de indivíduos; em segundo lugar estão as fundações, com 15\% de tudo o que é doado; e as empresas, com 5\% do total de doações.

Como se pode ver, é notável o ambiente propício para o desenvolvimento do mercado de e-filantropia focado em indivíduos no país em que, em relação à angariação P2P, destaca-se o popular e pioneiro caso das campanhas P2P de aniversário da Charity:Water $(\mathrm{CW})$.

\subsubsection{Histórico da Charity:Water}

A Charity:Water tem seu início relacionado à história pessoal de seu fundador, Scott Harrison, o qual até hoje é líder da OSC e grande inspirador de outros movimentos, OSCs e empresas de captação de recursos dos EUA.

Aos 23 anos, Scott era um promotor de casas noturnas e seu trabalho consistia em promover os eventos em diversas áreas de Nova Iorque. Após um período de cinco anos nesse estilo de vida, passou por uma espécie de crise de valores e aos 28 anos decidiu fazer o "oposto de sua vida": viver uma "vida limpa" e fazer obras de melhoria para a sociedade (HARRISON; ROSE, 2012).

Para isso optou por se inscrever em alguma ação de voluntariado e - após ser rejeitado por uma série de OSCs - foi aceito na Mercy Ships, um grupo de voluntários médicos que visitam regiões necessitadas da África em navioshospitais.

Em 2004, embarcou no navio Mercy em direção à Libéria onde atuou por alguns anos. Sobre a experiência, Scott Harrison conta: "estava pasmo com a pobreza que focava as lentes da minha câmera fotográfica. Por anos, fotografei uma pobreza inimaginável. Na África ocidental, eu era um príncipe de novo. $\mathrm{Na}$ verdade, um rei. Um homem com cama, água limpa e bem alimentado" (HARRISON, 2006).

Como fotógrafo voluntário, seu trabalho era tirar fotografias dos doentes para criar um banco de imagens que servisse tanto para estudo interno dos médicos voluntários, quanto para a divulgação da organização social. Foi nesses meses de voluntariado que o jovem notou a imensidão de problemas sociais que desconhecia, entre os quais se destacou a questão da água suja, que resultava em 
diversos problemas de saúde, como o desenvolvimento de tumores e doenças como Esquistossomose e Hepatite A.

Em 2006, após várias visitas de voluntariado para a África, decidiu abrir sua própria organização social. Scott observa que, primeiramente, o nome da Organização seria Charity is, visto que seu objetivo era "reinventar a caridade", no entanto, posteriormente, decidiu enfatizar a solução para a crise da água, nomeando-a de Charity:Water (CW).

Ao analisar as versões antigas do website da CW, é perceptível a qualidade do design e o esforço que a OSC fazia para se diferenciar. Sobre isso, Scott comenta: "Eu peguei o que tenho de melhor; sou bom em promover coisas ... e, além disso, queria uma marca forte, como a 'Apple' ou 'Nike' das organizações sociais. Para isso investi numa boa marca, e num bom design de site" (HARRISON; ROSE, 2012).

As primeiras doações para a OSC iniciaram com o próprio aniversário de Scott promovido numa danceteria na qual se cobrou a entrada de 20 dólares que seria enviada para a construção de um hospital na África. O aniversário motivou a angariação de 15 mil dólares e isso possibilitou que a $\mathrm{CW}$ iniciasse seus primeiros trabalhos na África; logo após, foram enviadas para todos os convidados que participaram da campanha fotos comprovando o impacto.

Com a realização e sucesso de sua campanha de aniversário, Scott percebeu que tinha uma ferramenta importante em mãos, e possível para todos, visto que "todos fazem aniversário ao menos uma vez ao ano" (HARRISON; ROSE, 2012). Assim, o jovem incentivou que toda a sua rede criasse aniversários em prol da OSC, resultando em mais de 1200 aniversários off-line no decorrer dos anos, quando as pessoas transformavam seus presentes de aniversário em doações em prol da CW.

No entanto, nos primeiros anos, a ação não era promovida no website de forma automatizada. As pessoas que se interessassem por criar festas para o $\mathrm{CW}$ preenchiam formulários de interesse e eram contatados pela equipe que criava manualmente suas páginas de aniversário.

Segundo o entrevistado C2_F2, essa situação gerou um problema de 
escalabilidade das campanhas: o número de pessoas interessadas em efetivar campanhas de aniversário chegou a um ponto que a equipe da CW não conseguia atender a todos.

Conjuntura que levou, em 2007, a Scott e sua equipe decidirem investir no desenvolvimento de uma plataforma online que possibilitasse que os visitantes do website criassem suas próprias campanhas, indo além da categoria de aniversários: quaisquer temas de campanhas poderiam transformar-se em motivo de angariação para a causa. Segundo um dos funcionários da organização, presente na época: "Isso foi muito antes das plataformas que existem hoje em dia; se hoje é inovador, imagine na época!" (C2_F2).

Um dos fatores que propiciou o desenvolvimento da inovação na organização social foi o fato de ser mobilizada por uma equipe jovem, com espírito de startup, em que a mistura de inovação com tecnologia era um fator natural. Cultura interna que, segundo um dos funcionários, até hoje motiva muitos jovens a trabalharem e a serem voluntários na OSC (C1_F1).

Um outro ponto, que diferenciou fortemente a organização dentre outras OSCs, foi o chamado "Modelo 100\%" das campanhas de angariação P2P : o valor integral angariado iria direto para os projetos de água na África; nenhuma porcentagem iria para a equipe administrativa da $\mathrm{CW}$.

Para viabilizar o "Modelo 100\%", Scott explica: "Nós criamos duas contas separadas que nunca iam se misturar: a conta de projetos e a conta do administrativo. Inclusive, para mostrar que levamos a sério esse modelo, nós cobrimos do nosso bolso até a porcentagem gasta com os encargos das transações efetivadas com cartão de crédito nas campanhas online." (HARRISON; ROSE, 2012).

Segundo alguns dos membros da equipe (C2_F1, C2_F4, C2_F3), até hoje esse mesmo modelo está intacto e traz duas consequências: o desafio de conseguir doadores/ investidores que aceitem financiar a conta da equipe administrativa e a vantagem de se diferenciar das outras OSCs elevando as microdoações para $100 \%$.

De acordo com os funcionários, o "Modelo 100\%" de angariação nunca 
deixou de ser um desafio. Houve, inclusive, uma época específica em que as campanhas cresciam em quantidade substancialmente maior que as doações diretas para o administrativo.

"Nós estávamos indo tão bem na angariação online, que, devido às limitações do Modelo 100\%, íamos falir por falta de verba para manter a equipe administrativa." (C2_F4).

Nesse contexto de crise, considerando sua rede de contatos e a popularidade que a OSC tinha com o público jovem na época, a equipe fez contato com Mark Zuckerberg, Tom Anderson e Michael Birch - fundadores, respectivamente, das redes sociais Facebook, Myspace e Bebo - a fim de conseguir investimentos que possibilitassem custear os gastos administrativos da CW.

$\mathrm{O}$ único que respondeu positivamente ao e-mail para uma reunião foi Michael Birch. Na conversa, Birch foi assegurado que a OSC daria notícias de cada centavo investido e, após alguns dias, a reunião resultou no investimento de 1 milhão de dólares, financiando 32 meses da equipe administrativa.

De acordo com o funcionário C2_F6, a questão da transparência no investimento das doações e informação sobre o impacto social também é um dos grandes pilares da OSC. Em vista disso, a organização desenvolveu um de seus produtos em parceria com a empresa Google, denominado Dollars to Projects, cujos dólares angariados em campanhas de doadores são rastreados aos poços de água construídos pela $\mathrm{CW}$ utilizando o Google Earth.

Portanto, independente do quanto foi angariado, cada campanha de angariação recebe um relatório comprovando o impacto gerado (segundo C2_F4). O organizador e os doadores da campanha conseguem saber qual poço de água sua angariação ajudou a construir, as coordenadas de GPS, fotografias e as vezes até mesmo vídeos comprovando o impacto de suas doações.

A iniciativa de ligar e rastrear as doações nos poços de água mapeados via Google Maps, foi extremamente inovador em 2008 e muito divulgado pela OSC em seu website, o que segundo C2_F6 estimulou grande notabilidade digital da CW. A comunicação digital do Dollars to Projects pode ser vista a 
seguir, em um dos layouts do website da época.

Figura 15 - Versão de 2008 do website charitywater.org

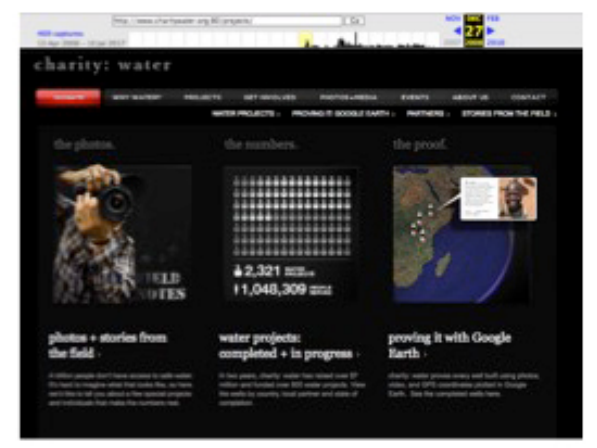

Fonte: Internet Archive - disponivel em: goo.gl/NLLva. Acesso em 1.07.2017

Tal diferencial da OSC em tecnologia, trabalhando-se os potenciais de dialogia e interatividade da $w e b$, gerou grande notabilidade da mídia e, com isso, muitas celebridades também chegaram a fazer campanhas de aniversário para a CW.

Atualmente conhecida como uma das mais inovadoras OSCs que realizaram a união de tecnologia com impacto social, tendo como produto principal as campanhas de aniversário, no decorrer dos anos a $\mathrm{CW}$ fez várias ações criativas de marketing, ações conjuntas de marca com empresas privadas, entre outras.

Com relação a campanhas de captação permanentes na organização social, destacam-se as seguintes:

- $\quad$ The Well

The Well é um clube direcionado para os maiores apoiadores financeiros da CW. A rede consiste em grandes famílias, fundações e empreendedores de tecnologia, que entendem a visão da organização permitindo que todo o valor de suas doações seja investido nos custos administrativos da OSC.

Por ser um clube de venture philanthropy, participam somente investidores de grandes aportes de capital, sendo o investimento mínimo de U\$ 30.000,00 (C2_F4).

- $\quad$ The Spring 
Ao entrevistar C2_F2 e C2_F4, ambos afirmaram que um dos erros estratégicos cometidos pela OSC, durante nove anos de atuação, foi o de não focar a conversão de doações recorrentes.

O funcionário C2_F4 afirma que o desafio duplo de separar as duas contas e angariar para duas "causas" correlatas, mas de públicos diferenciados, traz grande pressão para captarem para os custos administrativos - que são os investimentos mais difíceis de serem conseguidos - devido a isso em 2016 foi iniciada a campanha The Spring. Tendo como base que as pessoas já têm a cultura de pagar serviços de assinatura pela internet, a campanha consiste num clube de assinatura pelo qual as pessoas se comprometem a doar mensalmente o valor de 60 dólares ou mais para a causa da água (C2_F4).

“A cada ano nós começávamos do zero, com o início do clube The Spring, que já totalizamos mais de 8 mil assinantes" afirma C2_F4. As doações permitiram que a OSC planejasse suas ações com mais conforto devido a o clube possibilitar que as doações cubram gastos administrativos.

Devido ao recente lançamento e aposta como um agregador da sustentabilidade financeira da OSC, The Spring é a campanha mais mobilizada pela organização. O grande foco é conseguir cada vez mais assinantes, o que só foi possível, pois a OSC tem uma enorme rede online que cresce a cada dia por meio das mídias sociais em que atua e pelas campanhas de angariação pessoal criadas todos os dias. Nelas, além de doações, é ampliado o relacionamento da OSC com novos contatos (conhecidos do organizadores das campanhas de aniversário) os quais - se bem trabalhados - podem se converter em doadores recorrentes (C2_F4).

- Campanha de Setembro

A campanha de Setembro tem esse nome, pois remonta ao mês de aniversário do fundador da OSC, Scott Harrison, pelo qual a CW conseguiu suas primeiras doações e efetivou o primeiro projeto na África. Em prol dessa data, são reforçadas ainda com mais enfoque as campanhas de angariação pessoal e que os aniversariantes de setembro criem suas campanhas (C2_F2, C2_F3).

Até hoje, segundo C2_F2, as campanhas de aniversário são a categoria 
mais comum e que mais angaria na plataforma, está presente desde a fundação da OSC e mobiliza milhares de doações. Logo, as campanhas de aniversário são uma categoria de campanha simbólica para a CW, pois "tudo começou com um aniversário" (C2_F2).

\subsection{A plataforma Charity:Water}

Em 2009, foi para o ar a plataforma online de criação de campanhas P2P da CW. Entre seu lançamento em 2009 até 2017, foram realizadas mais de 90.000 campanhas de angariação P2P por meio da plataforma online, indicando o grande sucesso e diferencial da ferramenta que é protagonista de angariação da OSC.

\subsubsection{A jornada de experiência dos usuários na plataforma}

Para compreender a experiência dos usuários na plataforma, foi realizado um mapeamento das telas e interações que o organizador tem com a OSC, do qual resultaram as Figuras 17 e 19.

A seguir, a análise do conteúdo e estrutura do fluxo de usuários, a fim de aprofundar a experiência obtida na plataforma Charity:Water. A análise será permeada por excertos de entrevistas com organizadores e funcionários acerca de assuntos relacionados diretamente com o conteúdo e estrutura dos fluxo analisados.

\section{- Experiências de interação dos organizadores na plataforma}


Figura16 - Charity: Water: Fluxo do organizador da campanha

charity: water

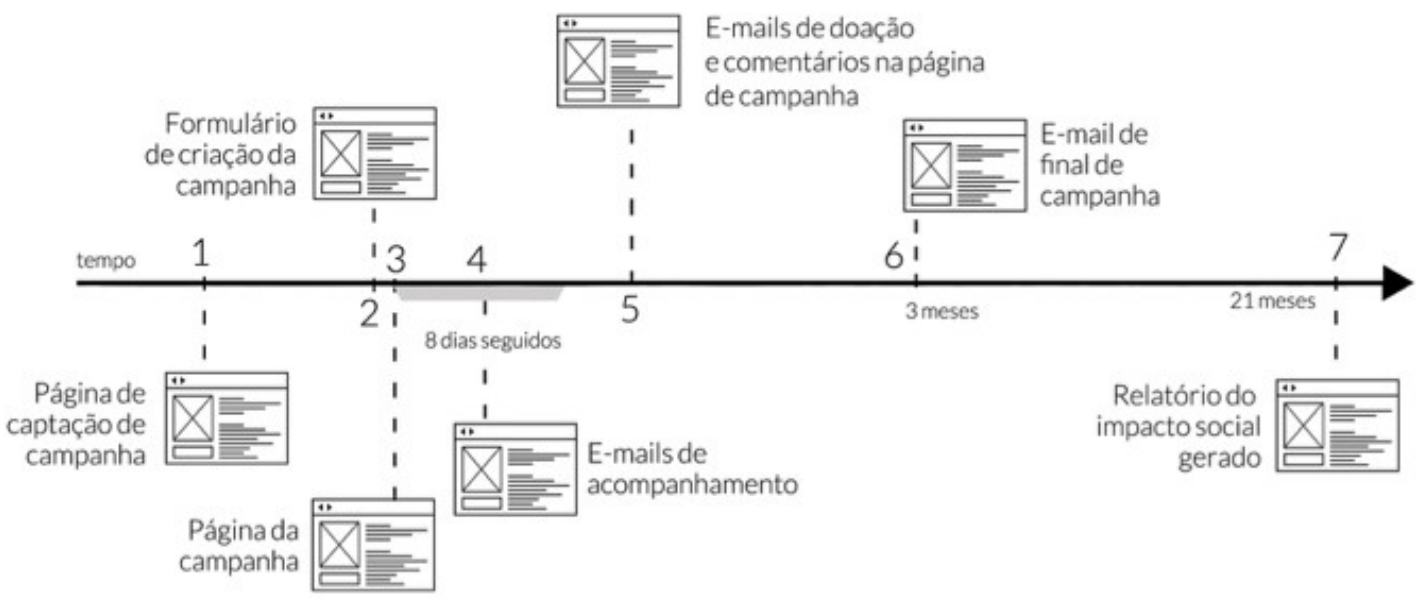

Fonte: A Autora.

\section{1) Página de Captação da campanha}

No website da OSC existem diversos links que direcionam para as campanhas de angariação P2P.

Todos esses links levam à página de captação e conversão de campanhas, a qual tem o objetivo de captar e-mails de pessoas que querem ser lembradas em seu aniversário e ressaltam alguns dos diferenciais da $\mathrm{CW}$, já mencionados: o "Modelo 100\%" e a comprovação do impacto social gerado pelo programa Dollars to Projects.

Ademais, o usuário é encorajado a se unir a uma comunidade de pessoas que angariaram servindo-se dos eventos pessoais de suas vidas.

Segundo o funcionário C2_F3, a pessoa que se inscreveu para ser lembrada de doar para seu aniversário é recordada por 2 e-mails, enviados respectivamente 30 e 15 dias antes da data comemorativa. Essa abordagem aumentou a conversão de campanhas para a OSC, visto que muitas pessoas se esqueciam da oportunidade de criar uma campanha quando se aproximava a data 
de seus aniversários.

\section{2) Formulários de criação de campanha}

Ao decidir criar sua campanha de angariação, o usuário é direcionado a um breve formulário no qual é necessário colocar o nome e a meta de angariação.

A meta de angariação é obrigatória nas campanhas e tem como sugestão inicial 350 dólares. Importante notar que a meta é orientada de forma visível e relacionada ao impacto social gerado. Por exemplo, ao colocar a meta de 30 dólares, o impacto também já é indicado na conversão do valor em água para uma pessoa.

Em entrevista com os organizadores, identificou-se que para alguns essa conversão interferiu na determinação da meta "eles te dão uma ferramenta para você mostrar às pessoas a importância da causa, e quantificam isso", por isso escolheu ajudar 50 pessoas, equivalente a 1.500 dólares, afirma o entrevistado C2_E14.

Após esses dados, o usuário deve preencher informações pessoais como nome completo, e-mail, senha e se está criando sua campanha de forma individual ou participando de alguma campanha coletiva, os times. A plataforma permite que os organizadores unam suas campanhas pessoais em times, possibilitando que empresas e escolas engajem gincanas internas de angariação para a causa ou corredores se inscrevam com seu time, somando o montante angariado em cada campanha P2P numa página maior.

\section{3) Página de campanha}

Como unidade de análise desta dissertação, considerou-se importante apresentar o layout de uma campanha (fictícia), a fim de ilustrar e situar o leitor acerca da dinâmica e funcionamento da mesma.

Também foram destacados, e identificados em ordem alfabética, itens na Figura 17 que serão desenvolvidos e aprofundados a seguir. 
Figura 17 - Charity:Water : página da campanha de angariação

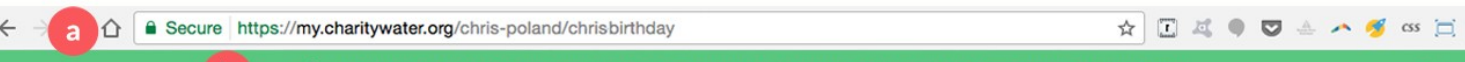

b Make the first donation, it shows you're committed to the cause and helps bulld momentum. Donate now

月 charity: water WHY WATER? OUR WORK ABOUT US $\quad$ FUNDRAISE SIGN IN

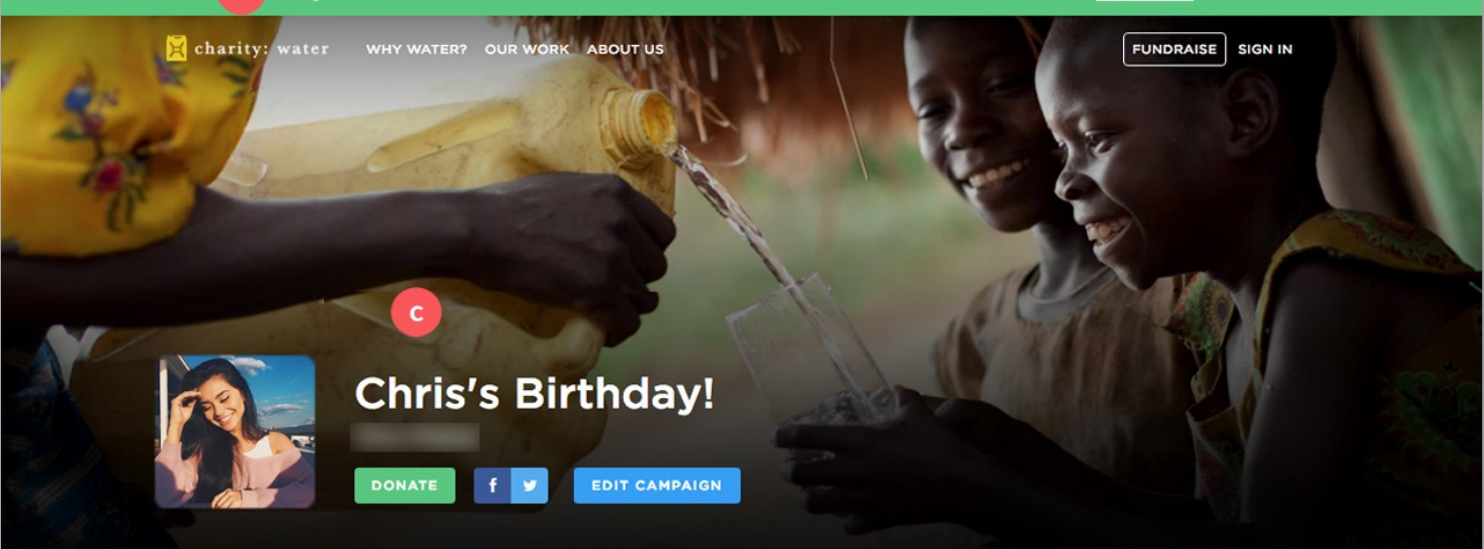

(d)

$\$ 9 \bigcirc$ Raised

230 people will get clean water (t) 22 days left to donate

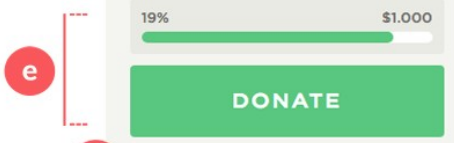

f SEE WHAT HAPPENS NEXT

\begin{tabular}{l} 
TOp donors listed by: $\quad$ AMOUNT TIME \\
\hline
\end{tabular}

Bob \& Sheila Tice

$$
\begin{array}{l|r|}
\hline \text { Jon \& Lauren Tice } & \$ 29 \\
\hline \text { David \& Lindsey Tice } & \$ 29 \\
\text { Lindsey AckleyPozzessere } & \$ 29 \\
\hline \text { 8 DONATIONS S PREV NEXT > } & \text { NENS } \\
\hline
\end{array}
$$$$
\text { Jon \& Lauren Tice } \$ 29
$$

h

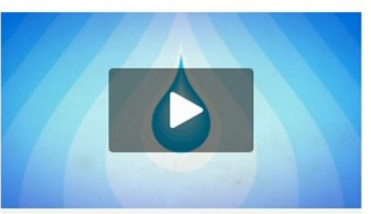

Diseases from unsafe water and lack of basic sanitation kill more people every year than all forms of violence, including war.
change that.

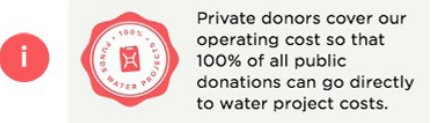
operating cost so that donations can go directly to water project costs.

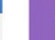

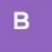

BOB \& SHEILA TICE donated $\$ 100$

Happy Birthday! More to come.

D DAVID \& LINDSEY TICE donated \$29

D An unusual birthday request, indeed! From an extraordinarily uncommon kind of person :) happy birthday!!

CHRISTY ALBORN donated $\$ 25$

C Happy Burfday

LINDSEY ACKLEYPOZZESSERE donated $\$ 29$

This is awesome, Great job, and happy early birthday!

$\begin{array}{llll}\text { get to know us } & \text { connect } & \text { resources } & \text { get involved } \\ \text { read our blog } & \text { contact us } & \text { download assets } & \text { volunteer } \\ \text { fleld stories } & \text { help center } & \text { see financials } & \text { brand partnerships } \\ \text { meet our staff } & \text { request a speaker } & \text { in-kind donors } & \text { shop our store }\end{array}$




\section{a) Sistema de segurança e personalização da URL}

A plataforma implementou o certificado de segurança e criptografia de dados SSL, seguindo o padrão de plataformas que efetuam transações financeiras.

Verificou-se também que o endereço online da campanha é personalizado com o nome do organizador e o título pelo qual a campanha foi chamada pelo seu criador. Este item é importante para o compartilhamento em mídias sociais e outros meios eletrônicos, visto que o link carrega uma referência de significado para a rede de conhecidos do organizador.

\section{b) Avisos personalizados com dicas de boas práticas na página da campanha}

Ao criar uma campanha, o organizador recebe dois tipos de aviso em sua tela: o de ser o primeiro a doar para dar início à campanha e motivar mais sua rede; em seguida, compartilhar o link em sua rede social.

Segundo o entrevistado C2_F6, uma orientação indicada é que o organizador faça uma lista de seus entes queridos mais próximos, com grande probabilidade de efetivar as doações, a fim de estimular que estes sejam os primeiros contribuintes. As primeiras doações geram um efeito de massa em outros apoiadores, que querem participar do movimento gerado.

\section{c) Personalização e divulgação da campanha}

A plataforma possibilita que os organizadores personalizem a foto de fundo, foto de perfil e o texto de sua campanha.

Tendo em vista diminuir a desistência da criação de campanhas por pessoas que a consideram muito trabalhosa, além de um formulário breve de criação, a plataforma cria uma campanha com sugestão para foto de capa e texto.

Esses podem ser alterados pelo organizador da campanha, mas, conforme se verificou no portfólio de campanhas criadas na plataforma, a maioria das pessoas serve-se do texto-padrão e da imagem de capa sugeridos pela OSC. 
Quanto à divulgação da campanha, os botões das principais mídias sociais são integrados à página a fim de possibilitar o compartilhamento nas mídias Facebook e Twitter.

\section{d)Atualização de impacto e montante arrecadado}

Na página da campanha registra-se o valor angariado e também o impacto direto que aquele valor viabiliza.

Essa conversão direta orienta o doador quanto ao montante para doar; ademais, muitas vezes os próprios organizadores estimulam valores específicos pedindo doações correspondentes à idade de comemoração de aniversário ou múltiplos dessa idade (C2_E5, C2_E9).

\section{e) Meta de angariação e chamada para o usuário doar}

A meta de angariação segundo alguns entrevistados seguiu uma lógica relacionada com o impacto que seria concretizado em um resultado de impacto social específico (C2_E4, C2_515), algum fato pessoal (C2_E5, C2_E9, C2_E10, C2_E11) ou foi escolhida de forma arbitrária (C2_E15, C2_E16, C2_E17, C2_E19, C2_E20).

Quanto ao botão de doação, tem cor distinta, e possui a chamada imperativa direcionando o usuário a doar. Segundo o funcionário C2_F4, isso foi proposital, pois eles consideram que os mandatos imperativos são importantes para suscitar uma resposta do usuários, portanto são atributos textuais bastante utilizados para gerar a ação de potenciais doadores.

\section{Demonstrativo de impacto}

Logo abaixo do botão de doação, a OSC apresenta um dos seus grandes diferenciais. Ao clicar o botão see what happens next, a plataforma comunica como irá rastrear as doações daquela campanha por GPS, prometendo aos doadores o recebimento de um relatório após alguns meses da finalização da campanha.

Com exceção dos entrevistados C2_E19 e C2_E8, os organizadores 
afirmaram que esse foi um fator importante que os estimulou a criar as campanhas e motivar sua rede a doar, pois garantiam à sua rede de conhecidos a legitimidade da causa.

\section{f) Lista e ranqueamento de doadores}

Caso o doador não escolha ficar anônimo, é apresentada uma lista com o nome de todos os apoiadores e ranqueada com os respectivos valores doados.

Com exceção do entrevistado C2_E13, os organizadores afirmaram não se incomodar pelo fato de aparecerem os nomes e valores, visto que também existe a possibilidade de o doador escolher o anonimato, houve em algumas campanhas o comportamento de competição por quem era o doador mais bem ranqueado na campanha (C2_E2). Segundo a entrevistada C2_E2, seu irmão havia doado um dólar a mais do que o valor maior, somente para ter o primeiro lugar da lista de doadores de sua campanha.

Ademais, destacaram-se alguns comportamentos com os quais os doadores anônimos se identificaram ao organizador da campanha (C2_E8). Sobre isso, a entrevistada C2_E8 relatou também que um tio seu doara uma quantia considerável de 1.000 dólares e que, apesar de ter doado de forma anônima, deixou claro para a aniversariante que fora ele apoiador.

\section{g) Vídeo sobre a causa}

Sobre o conteúdo do vídeo, verifica-se o uso do storytelling no qual a OSC se considera expert (segundo os funcionários C2_F2 C2_F4, C2_F6, C2_F7).

h) Selo do Modelo 100\%

Conforme pode ser verificado na Figura 17, a página de campanha da CW apresenta uma espécie de "selo", relembrando ao apoiador que $100 \%$ do dinheiro dele irão para a causa social que apoia.

Para os que quiserem compreender como a OSC viabiliza o Modelo $100 \%$, a imagem do selo, quando clicada, direciona o usuário para o blog de 
captação de recursos da OSC que explica o processo de angariação, composto pela captação direta para projetos na África por meio das campanhas pessoais e a captação de investidores privados pelo clube de investidores privados The Well.

Para alguns dos organizadores (C2_E18, C2_E5), o fato de que todo o dinheiro vai para a construção dos poços de água, sem ficar nada para a equipe administrativa da plataforma, é um grande diferencial que os motivou e também sua rede a apoiarem a campanha.

\section{i) Texto de campanha}

A campanha possibilita que as pessoas escrevam seus próprios textos chamando seus amigos e conhecidos para apoiarem sua campanha, caso contrário um texto-padrão é fornecido com a petição.

A fim de analisar seu conteúdo, apresenta-se, aqui, o texto-padrão, presente nas campanhas:

"Muitos de nós não tem ideia do que é passar sede. Nós temos muita água para beber - até a água de nossos banheiros é limpa!

"No entanto muitas pessoas do mundo não têm esse luxo. Todo dia, em média 1.400 crianças morrem por doenças causadas por água contaminada e falta de saneamento básico.

"Mas isso pode ser evitado. Existem soluções simples como a perfuração de poços, proteções de fontes e filtros Biosand que ajudam a providenciar água limpa para essas comunidades ao redor do mundo.

"Eu comecei essa campanha para ajudar a Charity:Water a construir esses tipos de projetos em vários locais necessitados do mundo, e estou procurando pessoas que possam me ajudar nisso.

"Por favor, doe para a minha campanha - qualquer valor que você puder ajudar será de grande ajuda.

"P.S.: $100 \%$ do dinheiro será usado para financiar os projetos que trazem água limpa para as comunidades e, quando eles forem efetivados, a Charity:Water irá nos enviar as fotografias e coordenadas de GPS para, assim, vermos exatamente a comunidade que ajudamos.” 
Dos entrevistados, $65 \%$ dos organizadores alteraram o texto-padrão de alguma forma, personalizando-o como quiseram; os outros utilizaram o textopadrão sem nenhuma alteração.

\section{j) Mensagens de organizador e doadores}

A página apresenta um elemento de interação e dialogia entre o organizador e os apoiadores, alguns organizadores utilizaram esse meio para agradecer, motivar e impulsionar os doadores; além disso, da mesma forma, os doadores utilizam-na para apoiar a ação, o organizador e motivar a campanha.

Ademais, para o organizador é possibilitada a funcionalidade de avisar por $e$ - mail todos os doadores de sua campanha assim que enviar qualquer informação - mensagens, fotografias ou vídeos - nos comentários de sua campanha.

\section{k) Disposição dos elementos no layout da campanha}

Foi curioso notar que, em contraposição aos diversos sites de $e$-commerce e de doação nos quais o botão de doação é colocado no extremo superior direito da tela do usuário, no caso das campanhas da $\mathrm{CW}$ o botão, bem como outras ferramentas de métrica da campanha estão alinhadas à esquerda do layout, bem abaixo da fotografia do organizador da campanha.

O funcionário C2_F7, um dos membros da equipe de design da $\mathrm{CW}$, em entrevista explicou a configuração ser devida a seu público-alvo: o layout da $\mathrm{CW}$ foi

formulado com base nas principais mídias sociais que seu público-alvo frequenta - Facebook e Twitter. Ao analisar com o funcionário o layout das referidas mídias, confirmou-se a congruência da disposição de elementos.

Segundo C2_F7, isso se dá a fim de diminuir a curva de aprendizado que existe quando o usuário é introduzido a alguma ferramenta de tecnologia; logo, ao utilizar a ferramenta desenvolvida pela $\mathrm{CW}$, o organizador e apoiadores já estão familiarizados com o layout e possíveis interações, visto que o layout foi 
inspirado em suas principais costumeiras mídias. Outra observação considerada foi que, como é possível notar na Figura 17, o vídeo não ocupa a parte principal da campanha.

Ao questionar tal observação com o designer da OSC, foi esclarecido que isso se deve ao fato da crença da equipe de que, no caso das campanhas de angariação pessoal, quem deve estar em destaque é o organizador: "ele é o herói" (C2_F7). Fatores relativos à organização social são, portanto, colocados fora do foco da campanha.

\section{l) E-mails de acompanhamento}

Em paralelo à campanha, durante os primeiros dias do processo, os organizadores informaram-nos que receberam e-mails com orientações, dicas e ideias para aumentar o potencial das campanhas. Alguns dos entrevistados nos encaminharam os respectivos e-mails, nos quais foi possível ver que, desde o dia de criação de campanha, o organizador recebia um e-mail por dia até o $8 .^{\circ}$ dia de mobilização.

Os e-mails consistiam nos seguintes temas e dicas:

--- dia 1 - Assunto: "Sua campanha foi criada! Veja os próximos passos." Conteúdo: dica para fazer a primeira doação, justificando que o organizador é engajado na causa e estimula os outros a doarem para uma campanha que havia sido iniciada.

--- dia 2 - Assunto: "Faça ser pessoal."

Assunto: "Sua campanha foi criada! Veja os próximos passos."

Conteúdo: dica para o criador da campanha personalizar sua página de angariação com fotos de perfil, de capa e com uma mensagem própria para assim dar seu toque pessoal e assim interagir mais fortemente com sua rede de contatos.

-- dia 3 - Assunto: "E-mail funciona."

Conteúdo: estímulo a mandar e-mails para amigos e familiares. Reforçase a importância de que esses sejam pessoais, para que os destinatários se 
sintam pessoalmente chamados a ajudar na campanha.

--- dia 4 - Assunto: "Compartilhe sua inspiração."

Conteúdo: apresentação de um vídeo e uma hashtag "\#nothingiscrazy" para a pessoa compartilhar nas mídias sociais e estimula que ela diga para seus amigos e conhecidos a razão de estar angariando para a CW.

--- dia 5 - Assunto: "Agradeça."

Conteúdo: apresentação da dica de agradecimento a todas as pessoas que já doaram para a campanha, e agradecimento público nas mídias sociais.

O e-mail motiva o organizador a não esperar que sua campanha finalize para agradecer, mas motiva-o a agradecer imediatamente após cada doação e assim que finalizar a campanha.

--- dia 6 - Assunto: "Seja muito criativo." Conteúdo: orientação para o organizador fazer coisas malucas e notáveis que "façam barulho em suas mídias sociais". Como exemplos de inspiração, convite a fazer obras de arte, gravar um vídeo.

--- dia 7 - "Foque em 5."

Conteúdo: estímulo para que o organizador se foque para conseguir cinco pessoas para doarem para sua campanha, justificando que, após a doação 
dessas cinco, as campanhas "pegam mais ritmo". Envio também de um link para o blog com mais oito dias para aumentar a eficiência das campanhas.

\section{5) Relatório de Feedback}

Apesar de serem posteriores à campanha em si, os relatórios de feedback apresentaram-se em algumas entrevistas como motivadores para as pessoas criarem as campanhas e também como uma ferramenta para estimularem sua rede de contatos a doarem.

Segundo o entrevistado C2_E10, o diferencial do relatório foi utilizado por ele para suscitar a confiança em doadores mais inseguros. Ademais, foi apresentado um modelo de relatório de feedback a fim de que organizadores e doadores possam ver como será o retorno de suas doações, esse relatório foi utilizado de exemplo por alguns entrevistados como ferramenta de persuasão de sua rede.

Os funcionários (C2_F5, C2_F6) complementam que, assim como é importante o pós-venda no marketing para o setor privado, a informação sobre o impacto social propicia uma experiência completa de doação e é uma das grandes propostas de valor da OSC.

Dessa forma, são providenciadas fotografias e vídeos do poço construído com as campanhas (quando uma campanha não consegue arrecadar o bastante para financiar um poço, ela se une a outras para obter o valor necessário), o número específico de pessoas ajudadas e as coordenadas de GPS do poço construído. Essas coordenadas são mais um diferencial resultante da forte orientação à tecnologia e inovação que a OSC possui (C2_F6), assim, cada poço possui GPS e está mapeado no software Google Earth.

--- A interação dos doadores na plataforma

Ao analisar o fluxo de campanhas da $\mathrm{CW}$, pode-se verificar a sequência de telas na Figura 19. 
Figura 18 - Charity:Water: fluxo do doador da campanha

charity: water

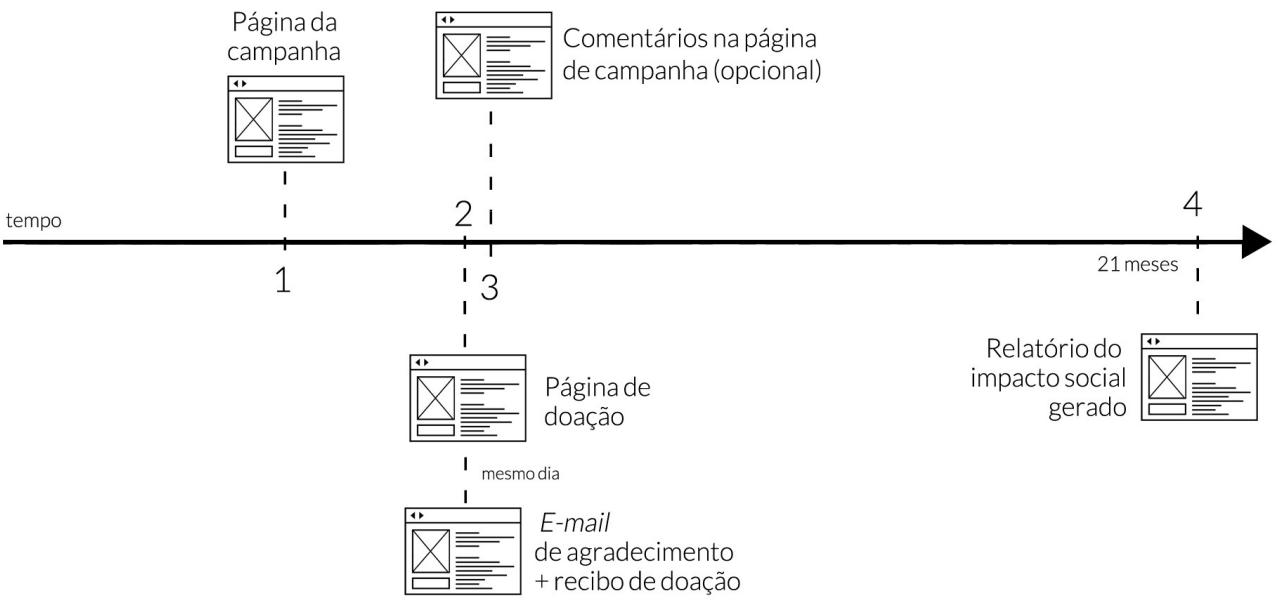

Fonte: A Autora.

\section{a) Acesso à campanha}

Ao acessar a campanha, o doador pode analisar a proposta, ver os comentários e doações de outros apoiadores, assistir ao vídeo promotor da causa, entender os diferenciais das organização e, principalmente, ser direcionado para a ação de doar, ao clicar o botão cuja cor contrasta com todo o resto do layout da campanha.

\section{b) Página de doação e e-mail de agradecimento}

Ao clicar o botão de doação, o usuário é direcionado para a página onde poderá efetivar a transação financeira. Nota-se que essa página possui um formulário dividido em três fases. À medida que o doador preencher os campos, novas etapas de preenchimento vão aparecendo até ser finalizada a doação. 
Figura 19 - Charity:Water: página de doação da plataforma

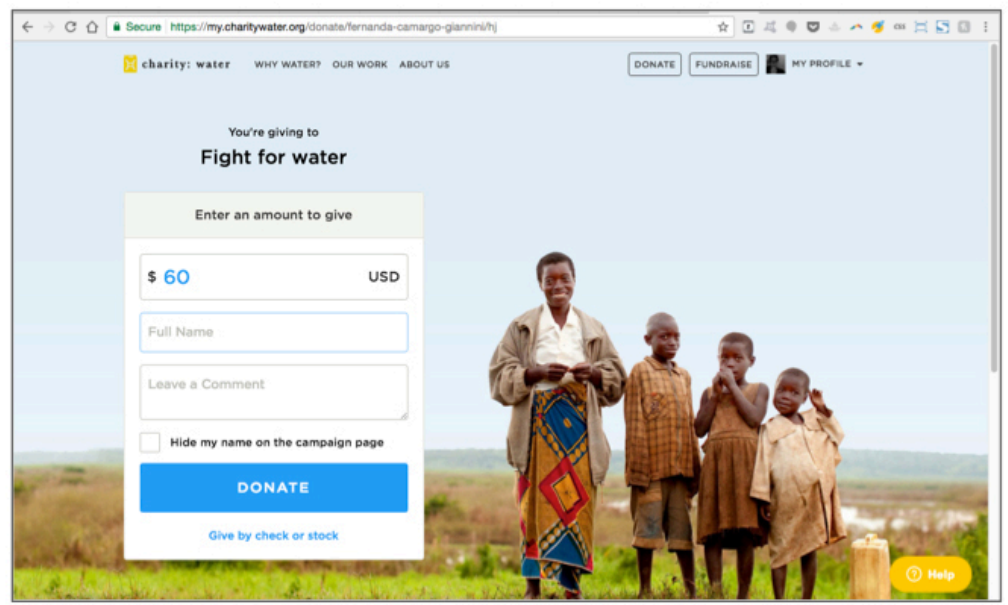

Fonte: Charitywater.org. Disponível em https://goo.gl/1KVDRL acesso em 10.06.2017

C2_F7 afirmou que uma boa prática de e-commerce aprendida e utilizada pela OSC é a de pedir somente as informações imprescindíveis para efetivar a transação visto que, quanto mais campos de preenchimento, maior a chance de desistência do usuário.

Também foi possível observar que o valor-padrão sugerido é de 60 dólares, o que equivale a trazer água para 2 pessoas em situação de necessidade.

Como se observou nas demais páginas, a utilização imagética de ilustrações que representam o impacto social são suscitadas a todo o momento para os usuários.

Outro ponto importante é a diversidade de canais de pagamento apresentada. É possível doar por cheques enviados pelo correio para a OSC, Paypal e por cartão de crédito por meio da integração existente entre a $\mathrm{CW}$ e o sistema de pagamentos Stripe.

A cada doação efetivada, o doador recebe um e-mail que consiste na confirmação e no recibo de doação e também no agradecimento da OSC.

\section{c) Comentários na página de campanha}

Somente os doadores da campanha podem efetivamente comentar na campanha. Segundo o entrevistado C2_E29, essa possibilidade influenciou bastante sua rede, a ponto de seu pai resolver efetivar novamente uma doação porque tinha esquecido de tecer comentários na campanha. 
Além disso, nos comentários notam-se mensagens de incentivo e cumprimentos para o organizador ou até mesmo brincadeiras entre a rede. $\mathrm{Na}$ campanha do C2_E22, por exemplo, as pessoas comentaram com perífrases como "tia mais querida", "irmão mais lindo". Na conversa com o entrevistado, ele informou que seus entes queridos doavam também para poder interagir e participar dos comentários.

\section{d) Relatório do impacto social gerado}

Segundo alguns organizadores (C2_E1, C2_E2, C2_E10, C2_E16), o relatório de impacto social demonstrou grande influência nos doadores para propiciar o ato de doar: muitos perguntavam sobre se teriam uma informação sobre o dinheiro investido e, quando receberam o relatório, chegaram a comentar sua surpresa para os organizadores.

Apesar de esperarem essa resposta, a maioria das pessoas não estava acostumada em receber de OSCs a prestação de contas de suas doações. Para muitos organizador foi uma grande surpresa e motivo de conversa com os doadores das campanhas.

\subsubsection{Experiências dos organizadores na promoção de suas campanhas P2P.}

\section{a) Dados pessoais e de rede de contatos em mídias sociais.}

Foram entrevistados 11 homens e 9 mulheres que organizaram campanhas de aniversário na plataforma. Com exceção dos organizadores C2_E7 e C2_E19 que estão entre 40 e 55 anos, os organizadores entrevistados têm entre 30 e 35 anos e todos são ativos em mídias sociais. As mídias de mais acesso são Facebook, Twitter e Instagram. Todos tinham histórico de envolvimento com OSCs por meio de atividades como voluntariado e $75 \%$ já haviam doado para alguma causa social.

Entre as razões apontadas sobre a motivação de criarem sua campanha de aniversário, os organizadores selecionaram uma ou mais das razões apontadas a 
seguir:

--- viram em alguma entrevista/apresentação/livro ou conteúdo online que cita as campanhas de aniversário efetivadas pela $\mathrm{CW}$ e nelas se inspiraram (55\% dos entrevistados);

-.- sentiram que já tinham tudo aquilo de que precisavam, então decidiram trocar seus presentes por doações ( $25 \%$ dos entrevistados);

--- gostaram do diferencial do "Modelo 100\%" ou da transparência, pelos quais a $\mathrm{CW}$ é conhecida e assim quiseram ajudar $(10 \%$ dos entrevistados);

-.- pesquisaram organizações confiáveis em portais de avaliação de OSCs e conheceram a CW (15\% dos entrevistados);

--- ficaram motivados pela causa água ( $10 \%$ dos entrevistados);

--- tiveram uma experiência pessoal com a OSC a ponto de quererem ajudar (5\% dos entrevistados).

\section{b) Assessoria da plataforma ao organizador}

Muitos organizadores afirmaram terem achado a criação das campanhas um processo fácil e rápido (C2_E2, C2_E6, C2_E8, C2_E19, C2_E20), divertido (C2_E1) e que a riqueza de materiais informativos disponibilizados possibilitou que sua rede fosse educada para a causa (C2_E9).

Outro material de apoio que a plataforma oferece é um kit de artes digitais desenvolvidas a fim de serem utilizadas como ferramentas para aumentar a angariação de sua campanha e a notabilidade de sua rede de contatos.

Esse kit digital é composto de: fotografias de várias resoluções, um miniguia de uso de marca - com orientações de como utilizar a marca, quais as dimensões ideais, entre outros - seis vídeos desenvolvidos com o objetivo de educar para a causa da água; imagens em dimensões específicas para Twitter e Facebook, bâneres para serem integrados aos códigos de sites, pôsteres para serem impressos.

Como se pode notar, a grande maioria do material, foi desenvolvido para ser utilizado no meio digital e angariar notabilidade da rede de contatos dos 
organizadores.

Muitos dos entrevistados informaram terem utilizado esse material, trocando suas fotos de capa no Facebook por alguma das imagens sugeridas, divulgando vídeos e outros. Até mesmo criaram sua própria arte com base nas imagens apresentadas. Sobre isso, um dos entrevistados reforça: "Eles montam um pacotinho muito bom; eles te dão o material, te sugeriam um post bom para o Facebok. Eles fazem um material para você" (C2_E9).

Logo, tendo em vista o material explicitamente disponibilizado para as campanhas, os organizadores informaram que foram bem assessorados e não sentiram falta de contatar diretamente a plataforma.

\section{c) Ações mobilizadas pelo organizador}

Sobre as práticas utilizadas pelos organizadores para impulsionar suas campanhas para sua rede, foram relatadas as seguintes:

(1) enviou mensagem-padrão para a sua rede de contatos em mídias sociais;

(2) enviou mensagem personalizada para cada pessoa de sua rede de contatos;

(3) relembrou seus contatos, com mensagens pessoais, para efetivarem a doação;

(4) relembrou seus contatos, com mensagens-padrão sobre sua campanha;

(5) utilizou múltiplos canais de contato com a rede de apoiadores (com exceção de redes sociais, telefone, ao vivo, whatsapp, entre outros);

(6) utilizou material fornecido pela CW;

(7) criou material de divulgação, como convites para a festa de aniversário, divulgando a campanha, vídeos, imagens de lembrete e divulgação nas mídias sociais;

(8) comemorou o aniversário e arrecadou na festa;

(9) aplicou uma estratégia previamente definida;

(10) efetivou abordagens criativas de interação com a rede de contatos;

(11) interagiu com a equipe e/ou seguiu alguma das dicas de campanha enviadas; 
(12) explicou como seriam as respostas às doações e/ou o Modelo 100\% de forma explícita para sua rede de contatos.

Quadro 7 - Charity:Water: práticas de mobilização das campanhas realizadas

\begin{tabular}{|c|c|c|c|c|c|c|c|c|c|c|c|c|c|}
\hline Código & $\begin{array}{l}\text { Status de } \\
\text { campanha }\end{array}$ & (1) & (2) & (3) & (4) & (5) & (6) & (7) & (8) & (9) & (10) & (11) & (12) \\
\hline C2_E1 & bem sucedida & $\mathrm{x}$ & & $x$ & $x$ & $\mathrm{X}$ & & & $x$ & $x$ & $x$ & & \\
\hline C2_E2 & bem sucedida & $x$ & $x$ & & & $x$ & $x$ & & & & $x$ & $x$ & $x$ \\
\hline C2_E3 & bem sucedida & $x$ & & & $x$ & $x$ & $x$ & $x$ & $x$ & & & & \\
\hline C2_E4 & $\begin{array}{l}\text { muito bem } \\
\text { sucedida }\end{array}$ & $x$ & $x$ & $x$ & $x$ & $x$ & $x$ & $x$ & $x$ & $x$ & $x$ & $x$ & $x$ \\
\hline C2_E5 & bem sucedida & $x$ & $x$ & $x$ & & $x$ & & & & & & & \\
\hline C2_E6 & bem sucedida & $x$ & $x$ & & & $x$ & & & & & & & \\
\hline C2_E7 & $\begin{array}{l}\text { muito bem } \\
\text { sucedida }\end{array}$ & & & $x$ & & & $x$ & $x$ & $x$ & & & $x$ & \\
\hline C2_E8 & bem sucedida & $x$ & & $x$ & & $x$ & & & & & & & \\
\hline C2_E9 & bem sucedida & $x$ & $x$ & $x$ & $x$ & $x$ & $x$ & & & & & & \\
\hline C2_E10 & $\begin{array}{l}\text { muito bem } \\
\text { sucedida }\end{array}$ & $x$ & $x$ & $x$ & & $x$ & $x$ & $x$ & & & & & \\
\hline C2_E11 & $\begin{array}{l}\text { Abaixodo } \\
\text { ticket médio }\end{array}$ & $x$ & & & & $x$ & & & & & & & \\
\hline C2_E12 & $\begin{array}{c}\text { Abaixo do } \\
\text { ticket médio }\end{array}$ & & & & & $x$ & & & & & & & \\
\hline C2_E13 & $\begin{array}{c}\text { Abaixo do } \\
\text { ticket médio }\end{array}$ & $x$ & & & & $\mathrm{x}$ & & & & & & & \\
\hline C2_E14 & $\begin{array}{c}\text { Abaixo do } \\
\text { ticket médio }\end{array}$ & $\mathrm{x}$ & & & $x$ & $x$ & $x$ & $x$ & & & $x$ & & \\
\hline C2_E15 & $\begin{array}{c}\text { Abaixo do } \\
\text { ticket médio }\end{array}$ & $x$ & & & $x$ & $x$ & $x$ & $x$ & & & & & \\
\hline C2_E16 & $\begin{array}{l}\text { Abaixo do } \\
\text { ticket médio }\end{array}$ & $x$ & & & & & & & & & & & \\
\hline C2_E17 & $\begin{array}{c}\text { Abaixo do } \\
\text { ticket médio }\end{array}$ & $x$ & & & & & $x$ & $x$ & & & & & \\
\hline C2_E18 & $\begin{array}{c}\text { Abaixo do } \\
\text { ticket médio }\end{array}$ & $\mathrm{x}$ & & & & $x$ & $x$ & $\mathrm{x}$ & & & & & \\
\hline C2_E19 & $\begin{array}{c}\text { Abaixo do } \\
\text { ticket médio }\end{array}$ & $x$ & & & & $x$ & & & & & & & \\
\hline C2_E20 & $\begin{array}{c}\text { Abaixo do } \\
\text { ticket médio }\end{array}$ & $x$ & $x$ & & & $x$ & & & & & & & \\
\hline
\end{tabular}

Fonte: A Autora.

\section{d) Campanhas criativas}

Alguns organizadores tiveram abordagens criativas as quais geraram notabilidade de sua rede para suas campanhas de aniversário. Um exemplo foi o organizador C2_E14 que pintou o cabelo de azul para lembrar sua rede de que estava angariando para a causa água.

Também foram oferecidas recompensas como uma rodada de cervejas para os apoiadores da campanha (C2_E1) e outras mais ousadas, como no caso do organizador C2_E4, que criou uma campanha de aniversário para seus pais e propôs que, a cada dólar doado/arrecadado para a campanha, ele colocaria mais dois dólares. $\mathrm{O}$ organizador chegou, inclusive, a pedir à equipe da $\mathrm{CW}$ que divulgasse nas mídias sociais da organização, o que acarretou a angariação treze 
vezes acima do tíquete- médio de campanha, mobilizando dezenas de doadores.

\section{e) Reflexões do usuário-organizador sobre o resultado e aprendizados que obtiveram nas campanhas.}

Sobre o resultado e práticas realizadas nas campanhas, alguns dos organizadores com campanhas abaixo do tiquete-médio afirmaram terem feito a única ação de divulgar em suas redes sociais, não chegando a falar proativamente com a sua rede: "se alguém me perguntasse o que eu queria de aniversário, eu mencionava a campanha", afirma C2_E18; ou mesmo "eu fiquei com vergonha de pedir para apoiarem, pois isso gera um constrangimento nas pessoas" (C2_E12).

Observou-se também que $40 \%$ dos organizadores afirmaram na entrevista terem tido experiências negativas com outras OSCs antes de criarem a campanha. A proposta de inovação e transparência que a organização realiza chamou-lhes a atenção estimulando-os ao envolvimento maior com a CW. Sobre o recebimento dos relatórios e prestação de contas com fotografias e coordenadas em GPS, C2_E13, afirmou ter testado antes para garantir a veracidade da comprovação do impacto, "eu até fiz uma campanha antes, de teste, e doei só pra ver se funcionava mesmo".

Essa desconfiança foi notável também na rede de apoiadores que chegavam a questionar os organizadores sobre qual porcentagem que iria realmente para a organização e quanto ficaria para pagar a equipe administrativa dela. Nisso, o "Modelo 100\%" e a comprovação do impacto foram pontos eficientes utilizados pelos organizadores para convencer sua rede de contatos a contribuir com suas campanhas.

Para alguns organizadores, a inovação da $\mathrm{CW}$ não consistiu somente na tecnologia desenvolvida, mas também em sua comunicação ressaltando aspectos relativos ao design da plataforma (C2_E1, C2_E8, C2_E9, C2_E10, C2_E16, C2_E20), ou mesmo quanto ao teor emocional das mensagens divulgadas pela OSC (C2_E12).

Todavia, apesar de a experiência de criação e mobilização das campanhas 
ser satisfatória para a maioria dos organizadores, também foram apontados aspectos negativos principalmente quanto às etapas posteriores às campanhas.

A comunicação sobre o prazo no qual receberiam os relatórios de impacto social não estava clara, segundo alguns dos organizadores (C2_E2, C2_E9, C2_E14); outros achavam que o tempo para receberem o relatório deveria ser menor (C2_E2), o que desmotivou sua rede de apoiadores. A esse respeito, C2_E2 afirmou: "Eu preciso dar uma satisfação pra eles; não dá pra ser em 21 meses".

A relativa sensação de demora levou muitos organizadores a afirmarem que nem ao menos se lembravam de seus relatórios e que perderam o contato com a $\mathrm{CW}$, que passou a deixar de enviar e-mails após o fim de suas campanhas, o que, segundo C2_E10, deixou a experiência um pouco incompleta.

\subsubsection{Experiências da plataforma nas promoção das campanhas P2P}

Além do material de apoio presente no website, a CW possui uma área no escritório chamada Donor Sucess na qual a equipe se mobiliza para atender ligações de organizadores e, também, dando especial apoio quando o sistema da plataforma identifica uma campanha que cresce mais que o normal, mostra-se muito criativa ou é aberta por uma celebridade. Em paralelo são divulgadas as campanhas eleitas mais inspiradoras no blog e mídias sociais da organização a fim de inspirar que outras pessoas iniciem sua angariação P2P na plataforma (C2_F5).

Nas entrevistas também foi indicado que a organização tem outras métricas de sucesso das campanhas além da angariação financeira. Segundo C2_F5 cada campanha angaria, em média, 1.000 dólares, movimentando 13 a 15 doadores em média. Da quantidade de pessoas que apoiaram as campanhas, cerca de 15\% efetivam outras ações com a organização como doações pontuais, recorrentes, parcerias com empresas ou mesmo a criação de suas próprias campanhas de aniversário.

Como o foco atual da $\mathrm{CW}$ está em aumentar a conversão para doadores 
recorrentes (C2_F6), foi-nos informado que eles têm um "pacote de e-mails" (que estava em teste) para serem enviados periodicamente aos doadores das campanhas, a fim de iniciar a construção de um relacionamento com essas pessoas, de forma que, no final, eles decidam entrar no clube de doações recorrentes, The Spring.

Mas isso não é fácil e ainda não foi testado totalmente, segundo afirma C2_F4. "Os estudos de angariação dizem que, para pedir outra doação, você precisa agradecer três vezes e é isso que procuramos fazer utilizando storytelling sobre as comunidades ajudadas pela Charity:Water e inspirados pela demonstração do impacto que as pessoas geraram”.

Acerca das experiências de boas práticas aprendidas com as campanhas de aniversário, C2_F4 e C2_F6 dão a dica para que os organizadores atuem além da postagem em mídias sociais:

"você não pode somente postar nas suas redes sociais e pedir pra doar; essa não é a forma pela qual os millenials se sentem ativados; eles se sentem ativados quando thes pedem diretamente para doar para sua campanha"(C2_F6).

Assim, a equipe indicou as seguintes boas práticas a serem realizadas pelos organizadores para potencializarem suas campanhas P2P:

(a) que sejam os primeiros a doarem para sua campanha a fim de mobilizar e pressionar sua rede;

(b) que elaborem mensagens pessoais para os destinatários; "quanto maior a pessoalidade, maior a eficiência" de conversão do pedido em doações (C2_F6);

(c) que o organizador explique o porquê de estar angariando para a causa;

(d) que forneçam materiais educativos sobre a causa e sobre a OSC apoiada para a rede de contatos;

Ao serem questionados sobre o processo de inovação contínua que realizam na CW, os funcionários C2_F4, C2_F6, C2_F7 explicaram que isso se deve ao duplo objetivo da organização de se considerar "uma empresa de 
tecnologia e uma OSC ao mesmo tempo" (C2_F7).

Logo, o funcionário C2_F6 esclarece que a flexibilidade de investimento em tecnologia e geração de impacto social de forma concomitante se explica pelo fato da OSC apresentar de forma bastante clara e diferenciada a Missão da Visão da organização. Como Missão, a CW tem o objetivo de "trazer água pura e limpa para todo o mundo", no entanto sua Visão é "reinventar a caridade" (C2_F6).

Assim, a Missão e Visão justapostas mantêm a organização social no ponto de tensão: a missão de resolver a crise da água está condicionada à visão de reinventar a caridade que a organização busca fazer por meio do investimento em tecnologia e inovação (C2_F6).

Dessa forma, a organização possui duplos pilares de investimento que se retroalimentam no processo de desenvolvimento da organização: o de gerar impacto social direto resolvendo a crise da água e o de inspirar e mobilizar pessoas a serem protagonistas de mudança social. 


\section{ANÁLISE E DISCUSSÃO DOS RESULTADOS}

No presente capítulo são abordados os estudos reflexivo e crítico de cada caso em separado dos quais evidenciamos as categorias de análise e sua classificação. Após a interpretação de cada caso, é realizado o cross-case entre os estudos, fornecendo o insumo para responder à questão desta pesquisa.

\subsection{Apresentação do quadro de análise das campanhas P2P.}

Como resultado da coleta de dados dos casos abordados, foram identificadas categorias e unidades de análise relativas ao desempenho da plataforma e às práticas dos organizadores para a mobilização das campanhas.

Quanto ao desempenho da plataforma, os fatores mostraram-se independentes e serão abordados mais especificamente em cada caso. No entanto, em relação à análise dos dados das práticas realizadas pelos organizadores das campanhas - caracterizadas nos Quadros 6 e 7 do Capítulo 4 foram verificadas unidades de análise correlacionadas e com graus de interferência específicos na performance das angariações, sendo agrupadas entre as seguintes categorias:

- Grau de personalização - trata-se de como o criador de cada campanha personalizou e preparou sua página no que tange a imagens e texto pessoais;

- Grau de interação - refere-se à estratégia utilizada pelo organizador para divulgar sua campanha, composta por canais de comunicação utilizados, se foi divulgada por meio digital ou off line, e se o pedido foi endereçado de forma massiva ou personalizada para cada membro de sua rede de contatos;

- Qualidade do discurso do pedido - consiste no modo pelo qual a petição de doação foi apresentada para a rede de contatos, com os aspectos identificados influenciadores dele. 
Assim, de acordo com cada categoria apresentada, para orientar um estudo completo e possibilitar uma comparação sistemática das campanhas, foram elaborados quadros de classificação e análise das ações de mobilização evidenciadas, e atribuidas pontuações de intensidade às unidades de registro utilizando-se a frequência ponderada apontada por Bardin (2006).

As categorias contribuintes à performance das campanhas foram pontuadas a partir da base comum de 1 ponto positivo. No entanto, ao contrastar práticas identificadas nos Quadros 6 e 7 desta dissertação, em ambos os casos estudados ações como o pedido personalizado online ou o fato do organizador pedir de forma proativa foram evidenciadas como coincidentes em praticamente todas as campanhas bem-sucedidas e ausentes nas que ficaram abaixo do tiquetemédio esperado, portanto atribuiu-se uma intensidade maior para estas ações visto a denotarem maior influência no resultado de sucesso das campanhas $(+2$ pontos).

A análise dos textos de petição dos organizadores em cruzamento com dados das entrevistas e resultados das campanhas também permitiu que fossem identificados comportamentos e exposições do pedido de doação inibidores da performance das mesmas - sendo assim os respectivos elementos atribuídos a uma pontuação de grau negativo $(-1)$.

Portanto, da referida análise das categorias e unidades influentes nas campanhas resultaram os Quadros 8, 9, 10, pelos quais orientou-se a análise final e comparativa de cada caso. 
Quadro 9 - Avaliação da interação entre organizador e sua rede

Quadro 8 - Avaliação da personalização da página de campanha online

\begin{tabular}{|l|l|}
\hline \multicolumn{2}{|c|}{ Grau de Personalização } \\
\hline Personalizou foto de perfil & 1 \\
\hline Personalizou foto de capa & 1 \\
\hline Personalizou texto & 1 \\
\hline
\end{tabular}

Fonte: A Autora.

\begin{tabular}{|c|c|}
\hline \multicolumn{2}{|c|}{ Grau de interação } \\
\hline Pedido massivo online & $1 /$ canal $^{*}$ \\
\hline Pedido individual online & 2 \\
\hline Pediu ao vivo & 1 \\
\hline Fez repescagem de contatos & 1 \\
\hline Divulgou em festa de aniversário & 1 \\
\hline Planejou a divulgação & 1 \\
\hline $\begin{array}{c}\text { Seguiu dicas ou interagiu com } \\
\text { a equipe de suporte }\end{array}$ & 1 \\
\hline
\end{tabular}

* Grau de interação medido por frequência absoluta (1 ponto por canal utilizado). Fonte: A Autora.

Quadro 10 - Avaliação do discurso do pedido

\begin{tabular}{|c|c|c|}
\hline \multicolumn{2}{|c|}{ Qualidade do discurso do pedido } \\
\hline Pediu de forma proativa & discurso direto & 2 \\
\hline \multicolumn{2}{|c|}{ discurso indireto 1} \\
\hline Argumentos emocionais/empatia com a causa & 1 \\
\hline Argumentos de eficácia/confiança na causa & 1 \\
\hline Relacionou o discurso com assuntos pessoais & 1 \\
\hline Originalidade/criatividade no pedido & 1 \\
\hline Explicou o problema a ser combatido & 1 \\
\hline Apresentou a OSC apoiada & 1 \\
\hline Elaborou o próprio material para o pedido & 1 \\
\hline Divergiu do pedido de doaçao financeira & -1 \\
\hline Apresentou argumentos inibidores de doações & -1 \\
\hline
\end{tabular}




\subsection{Análise do Caso 1: A plataforma Eventos do Bem}

Conforme mencionado, os dados coletados das entrevistas e documentação resultaram em categorias relativas a ações de suporte da plataforma e da prática de mobilização dos organizadores.

As ações de divulgação efetuadas pelos organizadores das campanhas são analisadas segundo os Quadros 8, 9 e 10, resultando num quadro geral de análise, com a comparação da influência desses fatores entre as campanhas da plataforma Eventos do Bem.

\subsubsection{Análise das ações promovidas pela plataforma Eventos do Bem.}

Como resultado dos dados levantados, serão analisadas a seguir as categorias identificadas como provenientes de ações relativas à plataforma promotora das campanhas.

\section{a) Design e experiência dos usuários na plataforma}

O design foi apontado pelos organizadores como uma melhoria necessária na plataforma; segundo eles, o fato de o layout ser pouco atrativo interferiu na divulgação e compartilhamento das campanhas nas mídias sociais.

Além disso, ressaltou-se a necessidade da adequação do design aos aparelhos de celular, o que foi considerado um dos grandes canais de divulgação pelos organizadores por meio de aplicativos de Whats app e mensagens pelo aplicativo do Facebook. Ao cruzar essa necessidade com os dados de acesso à plataforma, nota-se que a proposição é relevante, visto que $64 \%$ dos acessos ocorre por meio de aparelhos celulares ou tablets.

Quanto à experiência dos usuários, notou-se que a confiança e transparência são sentimentos que devem ser estimulados por ações que reforçam a legitimidade da plataforma e das organizações apoiadas.

Durante a mobilização das campanhas, os organizadores ressaltaram a 
necessidade de receberem relatórios financeiros completos sobre as transações da plataforma. Queriam saber quais pagamentos foram efetivados, boletos emitidos e até o eventual cancelamento de transações online dos cartões de crédito de seus contatos.

Notou-se certa insegurança dos organizadores e a necessidade de transparência durante todo o processo de doações. Muitas vezes, devido à responsabilidade de mobilizarem a campanha em seu nome, alguns relataram que sentiam o dever de atender e informar a todos de sua campanha sobre o status das doações.

Fato que agravou-se com o problema de conhecimento em efetuar transações online apresentado por alguns dos doadores, por não possuírem o costume de comprar serviços pela internet. Alguns doadores colocavam dados incorretos de seus cartões de crédito ou mesmo tentavam validar doações sem terem créditos bancários. Eles não compreendiam os erros que cometeram no processo de pagamentos e informavam ao organizador que não encontravam suas doações entre as efetivadas na campanha.

Diante dessa falta de cultura de efetivar transações financeiras digitais, a didática da página de pagamentos e um sistema de aviso de confirmação de doações foi identificado como um item importante para melhorar a experiência dos usuários e concluir mais doações online.

Além da falta de conhecimento, outro ponto relatado pelos organizadores nas entrevistas foi o de que algumas vezes seus parentes e conhecidos - de idade mais avançada - afirmaram não se sentirem confortáveis em colocarem seus dados bancários na internet. Assim, elementos como identificação e certificados de segurança, que estavam explicitamente informados ao usuário, demonstraram não terem muita efetividade para alguns dos potenciais doadores, uma vez que muitas vezes esses não tinham a cultura de compreender o significado desses certificados.

\section{a) Taxa administrativa}


Em algumas das campanhas realizadas, os organizadores relataram que sua rede de contatos questionou a taxa percentual de transação cobrada pela plataforma, assim, foi mal vista por alguns a cobrança administrativa proveniente da startup.

Isso já havia sido identificado por teóricos como Weisbrod e Dominguez (1986). Os autores ressaltam a influência do "preço de doar" em vários apoiadores.

Ou seja, a relação entre o percentual de cada donativo direcionado a custos administrativos - como o de captação de recursos - e o valor que vai diretamente para a causa impactada influencia a decisão de algumas pessoas para doar.

Em contraposição, as OSCs e organizadores de campanhas compreendiam o valor gerado pela tecnologia sem apresentarem problemas quanto ao modelo de negócios da plataforma. Como exemplo, ressalta-se a experiência do organizador C1_E2 que, ao ser questionado por um dos doadores de sua rede sobre a taxa da plataforma, afirma que justificou as vantagens do tipo de tecnologia, pois, "sem essa administração dos recursos, eu nunca teria feito essa campanha. Não dá pra fazer na mão" (C1_E2) .

Todavia, mesmo com o reconhecimento de OSCs e organizadores do valor gerado pela plataforma, a taxa administrativa apresentou-se como um inibidor para alguns doadores que preferiram fazer as doações diretamente para a OSC ou entregar o donativo pessoalmente ao organizador, como comunicado em algumas entrevistas (C1_E2, C1_E3, C1_E5, C1_E8) .

\section{b) Assessoria das campanhas}

Por não terem experiência em captação de recursos, no decorrer das campanhas os organizadores foram orientados pela equipe da plataforma com algumas dicas de divulgação. Nesse processo observou-se que, além dos elementos de inspiração para textos e abordagens de mobilização fornecidos, muitos organizadores basearam seus textos em campanhas bem-sucedidas, efetivadas previamente (como no caso da campanha C1_E9 cujo texto foi inspirado na C1_E3), demonstrando a necessidade de uma série de boas práticas 
de referência em casos de sucesso.

Paralelamente, os criadores das campanhas requisitaram materiais específicos sobre as OSCs e os projetos sociais, a fim de estimularem sua rede a doar e compor seu discurso de petição de donativos. Esse foi um aspecto importante utilizado inclusive para auxiliar os organizadores a sanarem dúvidas apresentadas por seus contatos.

Ao analisar os textos desenvolvidos nas campanhas, notou-se que as angariações que obtiveram melhores resultados informavam com clareza aspectos sobre o problema social combatido e a OSC beneficiada. A informação clara e educativa de aspectos referentes à causa apoiada foram fatores contribuintes para o desempenho das campanhas $\mathrm{P} 2 \mathrm{P}$, aspecto afirmado por alguns dos organizadores (C2_F2, C2_F3, C2_F4, C2_F9).

Ao apresentar essa demanda de materiais informativos para as OSCs, evidenciou-se a carência de algumas entidades em fornecer o referido suporte. Contexto comum e já identificado por teóricos sobre o assunto (BENNET, 2005; SARGEANT, 2001), a maioria das OSCs apresentou dificuldades para elaborar material digital apropriado para a comunicação da causa e da organização, acarretando que a própria equipe da plataforma mobiliza-se voluntários para desenvolver material apropriado de divulgação.

Essas ações, apesar de beneficiarem as OSCs, comprometem a escalabilidade do processo de angariação, concluindo que a ferramenta de angariação online P2P apresenta algumas condições para o bom aproveitamento do seu potencial de captação. É uma ferramenta mais adequada e efetiva para organizações que possuem desenvoltura apropriada para fornecer suporte às necessidades das campanhas promovidas.

\section{c) Retorno sobre o impacto das campanhas}

Nas entrevistas realizadas, vários organizadores (C1_E6, C1_E8, C1_E9, C1_E10, C1_E20) mencionaram a necessidade dos resultados do impacto social gerado na angariação de suas campanhas; uns, a fim de complementar sua experiência de campanha e outros, para prestar contas à sua rede de contatos. 
O entrevistado C1_E10 afirma que ficou preocupado que a falta de transparência prejudicasse a própria relação que tinha com sua rede de contatos, pois, apesar de conhecer a OSC e ter segurança no bom uso dos recursos, a sua rede não tinha experiência com a causa apoiada. Logo, afirma que considera extremamente importante a prestação de contas e atividades realizadas, destacando-se a afirmação:

"principalmente para as pessoas que doaram, porque é uma relação que eu tenho."(C1_E10)

Analisando-se a citação, com as outras afirmações dos entrevistados, observou-se que o excerto mencionado enfatiza a característica específica das campanhas P2P de ressignificar o processo de doação utilizando a rede de relacionamentos dos próprios organizadores (SMITH et al., 2012).

A resposta sobre o impacto das campanhas, portanto, respeita a relação cultivada entre o organizador e os apoiadores, garantindo que não seja prejudicada, evitando situações de constrangimento para o organizador ao ser questionado sobre o resultado social de sua campanha por sua rede de conhecidos.

Importante também analisar que, considerando a autonomia que possuem nas campanhas de angariação, foi visível que a mesma necessidade havia sido percebida e solucionada por alguns dos organizadores, que comprometeram-se a visitar as OSCs com sua rede de apoiadores a fim de comprovar o destino das doações e agregar valor à própria experiência de campanha. Os entrevistados C1_E8 e C1_E20 afirmam que este retorno e envolvimento maior com o impacto social gerado fez muita diferença na experiência de angariação. Acerca da visita à OSC que apoiou em sua campanha, C1_E8 constata: “Com certeza, se eu não tivesse feito isso, a campanha teria valido metade do que valeu. Como eu nunca tinha ido antes a essa organização, para mim e meus amigos completou a experiência de um modo único, porque nunca tivemos contato direto com as pessoas que ajudamos."

\section{d) Envolvimento dos organizadores}


Por se tratar de uma plataforma de e-filantropia, além do costume de efetivarem transações online, outro fator influenciador foi a cultura de doação do usuário.

Notou-se que, apesar de todos os entrevistados terem se envolvido de alguma forma com causas sociais por meio de ações de voluntariado ou doações de roupas/alimentos, $80 \%$ afirmaram nunca ter efetivado uma doação financeira para uma OSC. Dessa forma, a ferramenta para eles tratou-se de uma primeira experiência de angariação de recursos paras OSCs, com valores que muitas vezes eles mesmos concluíram que não teriam condições de doar diretamente (C2_E2, C1_E3, C1_E10).

Ademais, outras pessoas fizeram sua primeira doação para as suas próprias campanhas de aniversário, e afirmam que o mesmo ocorrera com muitos amigos e parentes de sua rede de contatos. Nisso se destacou um elemento importante para o envolvimento dos organizadores: a existência da meta de angariação em cada campanha concretizou um objetivo e gerou a necessidade de sua conclusão, resultando no maior envolvimento dos organizadores na angariação a fim de se aproximarem para concluir a meta estipulada. É possível afirmar-se, portanto, que as campanhas viraram uma meta pessoal para alguns organizadores, apropriando o sucesso das campanhas como uma vitória pessoal, fenômeno identificado como específico das angariações com base em indivíduos pelas autoras Scharf, Payne e Smith (2015).

\subsubsection{Análise das ações promovidas pelos organizadores das campanhas da plataforma Eventos do Bem.}

As experiências dos organizadores na mobilização de campanhas de angariação da plataforma Eventos do Bem foram descritas de forma detalhada no item 4.1.4 desta dissertação. Dos aspectos observados, emergiram categorias de análise agrupadas em três blocos denominados grau de personalização, grau de interação e discurso do pedido. Estes blocos são independentes entre si e demonstraram ter influência para o sucesso das campanhas, os quais serão analisados a seguir, quando será feita a reflexão crítica e relação lógica das respectivas categorias identificadas. 


\section{a) Grau de personalização da página online das campanhas}

Todos os usuários personalizaram texto e fotografia da campanhas. Com relação aos vídeos, a maioria utilizou os vídeos-padrão das OSCs, com destaque aos usuários C1_E5, C1_E7, C1_E8 que elaboraram seus próprios vídeos de mobilização.

Os vídeos foram um fator de destaque na campanha de C1_E7, visto que o organizador desenvolveu uma série de gravações que atualizavam os apoiadores sobre o status de sua angariação, bem como relembravam sua rede de contatos para apoiarem sua campanha de aniversário. Segundo C1_E7, ao divulgar nas mídias sociais, essa abordagem gerou muita notabilidade para sua rede de conhecidos, retomando contatos distantes que doaram, causando surpresa no próprio organizador.

\section{b) Grau de interação}

Ao aprofundar um pouco mais as ações de mobilização realizadas pelos organizadores, foi possível constatar a presença de ações e comportamentos que influenciaram o processo de divulgação e resultaram em doações, caracterizando as campanhas bem sucedidas.

O principal fator destacado foi a importância do pedido pessoal do organizador para sua lista de contatos. Esse ponto foi indicado como diferencial pelos entrevistados C1_E10, C1_E5, C1_E6, C1_E4, C1_E3.

Ao explicar sobre o seu processo de divulgação da campanha, os organizadores apresentaram uma estratégia de divulgação que coincide por terem pedido nominalmente para cada pessoa de sua lista de contatos. Sobre isso, C1_E6 relata:

Divulguei para minha família mais pessoalmente, mandei o link, e expliquei pessoalmente o que era, e alguns deles doaram, vários dos meus amigos doaram, foi super legal. Eu recebi doações pequenas, mas de várias pessoas, acho que por isso que 
a gente conseguiu fazer a meta. Eu divulguei por inbox, tinha um controle de quem tinha me respondido, quem tinha doado, quem tinha confirmado que poderia...

A prática de fazer listas de controle dos contatos foi evidenciada pelos entrevistados C1_E3, C1_E4, C1_E5 e C1_E9. Para conseguir contatar toda a rede de forma rápida e otimizada, os entrevistados informaram que elaboraram a estratégia de criar "mensagens-padrão", personalizadas com o nome da pessoa, conforme explica C1_E3:

Eu já tinha uma mensagem-padrão, não muito comprida para não ser exaustiva e eu ia mudando a introdução para cada pessoa. Então eu dividia o processo, eu tentava mandar 60 mensagens por dia, todos os dias. Então, na primeira semana, eu já tinha mandado mensagem para todo mundo e na segunda semana era acompanhar e responder (C1_E3).

Com as mensagens pessoais também foi evidenciada pelos organizadores C1_E3 e C1_E4, como uma boa prática de conversão de doações, a repescagem das pessoas que não responderam, as quais eram contatadas novamente pelos organizadores. Ou, mesmo, a fim de indiretamente lembrarem sua rede de contatos, alguns (C1_E3, C1_E5) utilizaram a estratégia de agradecer publicamente a cada nova remessa de doações para sua campanha, nas redes sociais, possibilitando que indiretamente sua rede fosse lembrada sobre a proposta.

Dessa forma, ao analisar a eficiência das mensagens pessoais, nota-se a presença de fatores apontados na bibliografia referentes à pressão social do pedido (ANDREONI; RAO, 2011) acrescentado o grau de influência maior de quando a petição vem de um ente querido.

Mediante a pergunta de seus amigos, muitas pessoas optam por efetivar as doações, mais para garantir a relação do que a causa em si (MEER, 2011; SMITH et al., 2012). Logo, mais do que o pedido massivo, impessoal, o pedido pessoal, direcionado ao destinatário, deixa evidente a pendência de uma resposta ao seu ente querido, gerando um aumento da taxa de conversão (BRAITERMAN et al., 2016). 
Por isso, ao contrastar as ações e resultados entre as campanhas bem sucedidas e as abaixo do esperado, concluiu-se que mensagens massivas em mídias sociais são importantes para gerar notabilidade da rede, mas não convertem muitas doações. A conversão de doações foi relacionado diretamente ao contato direto e pessoalmente dirigido ao destinatário, por meio de mensagens, e-mails ou pedidos privados. Conforme conclui C1_E4, organizador que já realizou três campanhas de aniversário na plataforma Eventos do Bem, "vi que tem de ser uma coisa bem pessoal para a pessoa interagir; uma coisa mais genérica não funciona"(C1_E4).

Logo, da análise das práticas dos organizadores de campanhas bemsucedidas pode-se verificar que um dos fatores influenciadores das campanhas é a dedicação de tempo para sua divulgação, orientado por um planejamento, estratégia, clara de divulgação dos mobilizadores. Logo, a falta de tempo ou mesmo perda de motivação foram dois dos pontos levantados por alguns dos organizadores (C1_E19, C1_E15, C1_E12, C1_E11) como causa da falta de divulgação e maior interação com as pessoas de sua rede.

\section{c) Qualidade do discurso do pedido}

Considerando os estudos de Andreoni, Rao e Trachtman (2011), sobre a importância do pedido explícito para aumentar a conversão de doações, a presença de um pedido direto foi analisada especificamente nos textos das campanhas. Como resultado, foi possível destacar alguns fatores em comum e contrastantes entre as campanhas de sucesso e as demais.

Ao analisar o texto das páginas de campanhas de sucesso, observou-se que estas repetiram várias vezes o pedido de doação no meio do texto de apresentação da proposta, sendo sempre finalizadas com um call to action, isto é, a chamada imperativa para o leitor efetivar doação. Como pode ser exemplificado nos excertos:

Temos uma meta audaz para ajudar essas meninas! Gostaria de angariar $\mathrm{R} \$ 10.000$ para elas. Você me ajuda a realizar esse sonho? Se você puder doar $\mathrm{R} \$ 500, \mathrm{R} \$ 250, \mathrm{R} \$ 100$, ou o que 
puder, seria de grande ajuda!!

É muito fácil dar sua contribuição: basta clicar ao lado e doar a quantia que quiser! (Texto e grifos de C1_E3)

Meu objetivo: Se vc pudesse comprar itens de higiene ou uma refeição para uma pessoa de rua, quanto vc poderia gastar?

Qualquer contribuição já ajuda bastante, mas gostaria de pedir que contribuíssem com valores a partir de 10 reais e o limite é até onde o coração mandar ou o seu orçamento permitir. É muito fácil dar sua contribuição: basta clicar ao lado e doar a quantia que quiser!

(Texto e grifos de C1_E9.)

Por isso, estou pedindo doações de 200, 150, 100 reais ou o valor que vocês puderem ajudar para conseguir proporcionar um futuro de qualidade e que todos nós tenhamos uma participação nesse projeto fantástico. Vamos juntos? (Texto e grifos de C1_E9.)

Como se pode observar, os excertos apresentaram fatores como o estabelecimento de valores base para doação e o estímulo à empatia e inclusão do leitor no resultado da campanha, transformando a ação numa missão conjunta do organizador e seus apoiadores. Este comportamento foi fomentado pelos respectivos autores de forma proposital ao elaborar seu texto, como confirma C1_E3, "queria elaborar uma coisa na qual cada pessoa se sentisse participando e doando um valor que fizesse diferença para a pessoa, que todo mundo tivesse a sensação de ter contribuído".

Ainda sobre os textos dos pedidos de doações citados, foram estabelecidos valores referenciais para os doadores, ao comparar com o balanço de cada campanha, foi verificado que os valores influenciaram nos montantes doados pela rede dos doadores. Além disso, os organizadores que referenciaram valores maiores estimularam uma média de doações com valores mais elevados 
(por exemplo, o organizador C1_C3 obteve doações pontuais valores mais altos do que o C1_C9).

Em contraposição a boas práticas mencionadas, os discursos dos pedidos de contribuição de alguns dos textos das campanhas apresentaram dados confusos, finalizando sem pedir especificamente para o leitor efetivar uma doação. Nas entrevistas com os autores dos referidos textos, notou-se a incidência de elementos como vergonha ou timidez ao efetuar o pedido de forma mais explícita. Mencionaram que não se sentiam muito à vontade para pedir diretamente à sua rede de contatos e, por isso, não queriam "pressionar" seus conhecidos a doarem (C1_E15, C1_E13).

Sobre a qualidade das informações, verificou-se nos textos das campanhas bem-sucedidas que o problema social combatido e/ou a OSC apoiada foi comunicado com muita clareza, apresentando inclusive fatores de persuasão acerca da transparência e eficiência do impacto que seria gerado pelas campanhas. Eis alguns elementos que acompanharam outros argumentos para suscitar a confiança na legitimidade da instituição - "Não se preocupe, pois a ONG é muito séria e auditada pela Deloitte.” (C1_E7) - ou, até, convites para visitar a OSC para verificar a eficiência das doações realizadas - "Sintam-se à vontade para me procurar e tirar dúvidas, marcar uma visita para conhecer o projeto e o que acharem necessário.” (C1_E2).

Em muitas entrevistas, os organizadores contam que foram indagados sobre as OSCs e a eficiência do impacto social delas demonstrando que seus potenciais apoiadores queriam, além de presentear seu ente querido, verificar a seriedade da organização e o destino de sua doação.

Reforça-se, portanto, a importância que as OSCs forneçam materiais de informação e educação sobre a causa para os apoiadores envolvidos, principalmente para os organizadores das campanhas, visto que estes irão captar em prol da causa (ANDRESEN; STRATHMANN, 2007).

\subsubsection{Classificação das práticas de mobilização dos organizadores das campanhas da plataforma Eventos do Bem.}


A partir da análise realizada, foi perceptível a influência de alguns elementos específicos em graus de intensidade diferenciados nas campanhas de angariação P2P. Logo, com base nos Quadros avaliativos 8,9 e 10, apresentados no item 5.1, se classificou cada campanha P2P analisada, para poder efetivar uma análise comparativa entre as mesas e assim aprofundar o estudo. Esta classificação está apresentada no Quadro 11.

Quadro 11 - Eventos do Bem: análise das ações dos organizadores

\begin{tabular}{|c|c|c|c|c|}
\hline Código & $\begin{array}{l}\text { Statusda } \\
\text { campanha }\end{array}$ & $\begin{array}{c}\text { Grau de } \\
\text { personalização }\end{array}$ & $\begin{array}{l}\text { Grau de } \\
\text { interação }\end{array}$ & $\begin{array}{l}\text { Discurso do } \\
\text { pedido }\end{array}$ \\
\hline C1_E1 & bem sucedida & 3 & 4 & 4 \\
\hline C1_E2 & bem sucedida & 3 & 5 & 7 \\
\hline C1_E3 & $\begin{array}{l}\text { muitobem } \\
\text { sucedida }\end{array}$ & 3 & 12 & 6 \\
\hline C1_E4 & $\begin{array}{l}\text { muitobem } \\
\text { sucedida }\end{array}$ & 3 & 8 & 6 \\
\hline C1_E5 & bem sucedida & 3 & 6 & 3 \\
\hline C1_E6 & bem sucedida & 3 & 8 & 2 \\
\hline C1_E7 & bem sucedida & 3 & 5 & 8 \\
\hline C1_E8 & bem sucedida & 3 & 5 & 5 \\
\hline C1_E9 & $\begin{array}{l}\text { muitobem } \\
\text { sucedida }\end{array}$ & 3 & 8 & 6 \\
\hline C1_E10 & bem sucedida & 3 & 3 & 5 \\
\hline C1_E11 & abaixodoTM & 3 & 2 & 4 \\
\hline C1_E12 & abaixodoTM & 3 & 3 & 5 \\
\hline C1_E13 & abaixodoTM & 3 & 3 & 4 \\
\hline C1_E14 & abaixodoTM & 2 & 2 & 2 \\
\hline C1_E15 & abaixodoTM & 3 & 3 & 5 \\
\hline C1_E16 & abaixodoTM & 3 & 2 & 3 \\
\hline C1_E17 & abaixodoTM & 3 & 3 & 3 \\
\hline C1_E18 & abaixodoTM & 3 & 3 & 4 \\
\hline C1_E19 & abaixodoTM & 1 & 2 & 4 \\
\hline C1_E20 & abaixodoTM & 2 & 3 & 4 \\
\hline
\end{tabular}

$\mathrm{TM}^{*}$ - Tiquete-médio

Fonte: A Autora.

Ao contrastar a classificação de cada campanha, o Quadro 11 evidencia que as mobilizações que angariaram mais recursos, caracterizadas como "muito bem-sucedidas" - C1_E3, C1_E4 e C1_E9 - são as que possuem pontuação mais alta no grau de interação (com pontuações acima de 8). Em seguida, no índice de 
maior pontuação estão as campanhas consideradas bem-sucedidas e com o grau mais baixo as campanhas que angariaram aquém do esperado, com um grau de interação que não passou de 3 pontos.

Ao analisar este ponto em conjunto as entrevistas e práticas realizadas pelos apoiadores, nota-se que justamente por serem campanhas $\mathrm{P} 2 \mathrm{P}$, que focam a rede de relacionamento das pessoas, o montante de angariação é proporcional principalmente à iniciativa dos organizadores em ações de mobilização pessoal e direta pedindo para cada um de sua rede.

As campanhas analisadas indicaram terem seu desempenho dependente da dedicação do organizador. Esse é um processo que denota tempo e trabalho justamente pelo fato da interação compor uma série de práticas que devem ser realizadas constantemente, durante todo o processo da campanha. Logo, ao analisar os resultados nota-se que os fatores falta de tempo ou mesmo a vergonha em pedir, apontado como inibidor da interação para divulgação, foram identificados em $80 \%$ das campanhas que obtiveram resultado abaixo da média.

No entanto, como é possível se verificar na comparação das notas de cada campanha - como no caso da C1_E4 e C1_E9 - a interatividade não foi um influenciador exclusivo no resultado das mobilizações; o discurso do pedido também demonstrou influenciar a rede de doadores e contribuir para uma melhor performance das campanhas.

Ao analisar a pontuação das campanhas relativas ao "discurso do pedido", observa-se a prevalência de pontuação alta em $80 \%$ das campanhas bem-sucedidas e $50 \%$ das campanhas que ficaram abaixo da média, demonstrando que, embora em intensidade menor que o "grau de interação", o discurso do pedido é um influenciador no bom desempenho das campanhas.

Sobre o grau de personalização, como a maioria das campanhas realizou a personalização total da sua página - com vídeos, texto e imagens -não foi possível verificar se esta categoria teve influência relevante visto que as campanhas selecionadas não possibilitaram o contraste de pontuação. Todavia, considerando-se $\mathrm{o}$ aspecto da pessoalidade das campanhas focadas nos indivíduos criadores, é possível entender personalização das campanhas 
apresentou-se como uma forma de ligar a ação à pessoa do organizador, sendo mais um elemento mínimo, que reforça a pessoalidade e referência da campanha ao ente querido por seus apoiadores (HART; GREENFIELD; HAIJI 2007).

Portanto ao analisar e comparar as campanhas selecionadas, conclui-se que a ação-chave para a promoção das campanhas analisadas na plataforma Eventos do Bem foram as ações relativas à categoria denominada como grau de interação dos organizadores com sua rede. Entre as ações de interação analisadas e congruentes nas campanhas de sucesso se destacaram o pedido do organizador direto e pessoal para cada um da rede de contatos e as abordagens de pressão social como lembretes e repescagem de contatos. Atuações que demonstraram poder ser potencializadas com um discurso de petição bem elaborado, o qual deve sugerir e referenciar valores mínimos de doação, reforçar aspectos informativos e educativos sobre a OSC e a causa social apoiada.

\subsection{Análise do Caso 2: A Plataforma Charity:Water}

Com base nos dados coletados e descritos no item 4.2 deste estudo, a seguir é realizada a identificação e análise dos agentes mobilizadores e suas respectivas ações que influenciam o desempenho das campanhas de angariação P2P da plataforma Charity: Water.

\subsubsection{Análise das ações promovidas pela plataforma Charity: Water .}

Sobre as práticas da plataforma que influenciam as campanhas de angariação P2P, as unidades emergentes foram condensadas nas categorias a seguir.

\section{a) $\mathrm{O}$ investimento em design e tecnologia para engajamento da pessoa física}

Com uma equipe de 6 desenvolvedores $w e b$, segundo C2_F7 a plataforma Charity: Water passa por testes e otimizações constantes, resultando num design 
que, para alguns dos organizadores (C2_E1, C2_E10, C2_E13, C2_E16, C2_E20), diferenciou a organização de muitas outras OSCs.

Sobre isso, destacamos a interessante reflexão de um dos entrevistados:

A Charity:Water é uma ONG que tem a água como causa, mas desenvolvem a operação, o site, toda a experiência, para o usuário. Porque tem muita ONG que... beleza, a causa é maravilhosa...só que você vai tentar entrar no site deles, está fora do ar, ou aquele site é feio pra caramba, é difícil de entrar em contato...querendo ou não o site da Charity:Water é maravilhoso, o logo deles é lindo, as fotos são de altíssima qualidade, então não é um negócio que você fica...

'se eu postar uma foto desses caras aqui vai queimar minha imagem', é algo a que você quer estar associado. Então, o Charity:Water tem a causa água mas todo o esforço, todo o trabalho, toda a estrutura, todas as pontas de contato que você tem, foram muito bem pensadas, pra pessoa, pro ser humano, não pra causa água, então acho que tem muita gente lá, que entende que não adianta que você tenha uma causa maravilhosa e não consegue mobilizar pessoas para essa causa, e acho que isso a Charity: Water faz muito bem (C2_E10).

Com base na declaração citada evidencia-se que, além da importância do design e a elaboração de um material de qualidade para a comunicação da causa apresentada, as campanhas P2P atuam também como uma forma de expressão e cultivo da imagem pessoal dos organizadores. Por ser uma campanha pessoal, a estética e materiais dispostos acabam sendo relacionados à pessoa do organizador.

Ao discorrer sobre o esforço e investimento financeiro da $\mathrm{CW}$ na elaboração de um material de excelência, C2_E10 ressaltou a importância de que ele inspire e garanta uma boa imagem pessoal de si mesmo perante sua rede de contatos. Logo conclui-se que as campanhas também podem ser realizadas como um ato de protagonismo e até de vaidade pessoal dos organizadores.

Tais fatores, segundo o funcionário C2_F7, foram identificados pela 
OSC, por isso o foco das páginas de campanha, consiste em fazer com que seu organizador "seja o herói". Em vista disso, a organização dedica uma série de ferramentas e material de divulgação de qualidade aos mobilizadores de campanhas, de forma que eles sintam orgulho de divulgar em sua rede a campanha realizada na plataforma.

Logo, nota-se um aspecto singular da instituição, a CW se apresenta mais focada em investir em inovação para ampliar a cultura de doação, "mobilizando mobilizadores", do que na sua missão social. Como prova dessa postura se evidencia que todos os "produtos" de inovação desenvolvidos pela OSC - o "Modelo 100\%" "Dollars to projects" e a plataforma P2P Charity:Water centram-se no doador.

Esta postura é consciente e é explicada no relato dos funcionários que afirmam que, apesar de sua missão e roupagem jurídica de terceiro setor, a organização considera-se um híbrido de empresa de tecnologia e organização social (C2_F4). É pela diferenciação entre missão e visão da organização - de resolver a crise da água e reinventar a caridade, respectivamente - que se possibilita o investimento realizado em tecnologia e material de mobilização de apoiadores, aspecto pelo qual C2_F4 explica a causa da inovação constante em captação de recursos, que caracteriza a OSC.

Como visão de reinventar a caridade, a OSC investe fortemente em na mobilização de doadores, até por que, conforme foi evidenciado nas entrevistas, 90\% das pessoas mobilizadas fizeram por estarem inspiradas pela abordagem inovadora da organização, e não por estarem sensibilizadas primeiramente pela causa da água. Comprovando que a eficência deste mesmo modelo indenpende da causa social e portanto é passível de ser desenvolvido em outras OSCs.

\section{Storytelling e inspiração}

A técnica do storytelling é uma das práticas mais utilizadas no material de comunicação da OSC. Nos artigos, site e mídias sociais da CW são narradas histórias das comunidades ajudadas, experiências da equipe de funcionários nos países visitados, e histórias de organizadores que fizeram suas campanhas pessoais de angariação.

Segundo C2_F4, a abordagem do storytelling é um dos fatores mais 
considerados em todo o processo de construção de relacionamento da OSC com seus apoiadores. A CW investe em imagens alegres e motivadoras, focando bastante a solução que pretende providenciar; logo as histórias são compostas por temas sobre como a água limpa transformou comunidades, desenvolveu pequenos empreendimentos, entre outros.

Todavia, é importante frisar que essa é uma abordagem utilizada recentemente, ao analisar as versões mais antigas do website da OSC, notou-se que a comunicação anterior apresentava imagens focando o problema e a miséria vivenciada pela crise da água, estimulando sentimentos de pena e tristeza.

Ao apontar isso na entrevista, C2_F3 confirmou que essa mudança na comunicação da organização ocorreu de forma consciente, pois, perante as diversas abordagens testadas, a equipe conclui que "gerando o sentimento de tristeza, nós só estávamos afastando as pessoas e, num contexto em que o compartilhamento em mídias sociais são a chave de sucesso das empresas, a inspiração, e não a culpa, se mostrou uma estratégia mais eficiente e crítica para o nosso marketing de conteúdo.” (C2_F3)

A inspiração comunicada pela organização, em imagens e vídeos, apontada nas entrevistas demonstrou gerar o efeito de aproximar os apoiadores, aumentando a participação deles no consumo de conteúdo, doações e criação de campanhas $\mathrm{P} 2 \mathrm{P}$.

Devido a isso, a plataforma Charity:Water apresenta cores vibrantes e fotografias de crianças sorrindo com copos de água limpa, comunidades felizes bombeando seus poços de água e, também, fotografias de organizadores e eventos divertidos promovidos pelas campanhas $\mathrm{P} 2 \mathrm{P}$.

Segundo C2_F7, o storytelling tem esse poder de inspiração: ao convidar as pessoas a fazerem parte da história da causa, as campanhas de angariação P2P são uma forma de elas terem um papel ativo no combate à crise da água, misturando suas histórias pessoais e memórias de eventos como seu aniversário com a história da organização.

Como resultado, é possível contar com uma comunidade de apoiadores engajada, que considera a OSC não somente pelo seu impacto social nos 
beneficiários ajudados com os donativos, mas como parte de sua própria história pessoal.

\section{b) Transparência e comprovação de impacto social.}

Ao se analisar a plataforma virtual $\mathrm{CW}$ e as transcrições das entrevistas com os funcionários, destacaram-se dois elementos considerados inovadores pela organização: o "Modelo 100\%" e a comprovação do impacto social mediante fotografias e coordenadas de GPS dos poços de água construídos (Dollars to Projects).

Dos organizadores entrevistados $90 \%$ citaram o diferencial da transparência possibilitada pelo "Dollars to Projects", incentivo que era mencionado muitas vezes de forma conjunta com o "Modelo 100\%", demonstrando a clareza na comunicação da organização que repete constantemente esse diferencial de transparência nos materiais de divulgação, e na própria página das campanhas.

Numa análise mais profunda da ferramenta Dollars to Projects, verificouse que sua inovação não consiste no fato de comprovar e apresentar provas "visíveis" do impacto gerado, mas na abordagem da organização de comunicação e apresentação das informações, destacando-se novamente elementos de design e storytelling.

Quanto ao "Modelo 100\%", este foi considerado um agregador à confiança e eficiência do investimento das doações na causa apresentada. Muitos dos organizadores afirmaram que se fosse o contrário, que alguma porcentagem das doações custeasse a equipe administrativa da OSC, eles não fariam a campanha para mobilizarem seus contatos, visto a insegurança que teriam na eficiência da aplicação das doações na causa final.

Portanto, os dois modelos - 100\% Model e Dollars to Projects demonstraram-se benéficos para agregar valor à experiência de doação e mobilização das campanhas, sendo muito ressaltados pelos organizadores que, ao comentarem sobre a eficiência e o modelo de transparência, contrastavam às experiências negativas que tiveram em outras OSCs. 
No entanto, em relação ao "Modelo 100\%" é importante observar que, em uma conversa mais aprofundada com os funcionários da OSC (C2_F1, C2_F3), apesar de não financiar a equipe administrativa que gere a plataforma, este valor financia a equipe que atua diretamente na construção dos poços de água. Pode-se concluir, portanto, que tal modelo consiste numa estratégia de gestão na realocação de investimentos, para apresentá-los de forma mais amigável ao doador, comunicando maior eficiência de suas doações.

\section{c) Ferramentas incentivadoras de dialogia e pressão social}

Nas páginas das campanhas - vide o exemplo na Figura 17 - existe um quadro apresentando publicamente os apoiadores e as respectivas doações, sendo estes ranqueados em ordem decrescente de valores. Apesar de haver a possibilidade de doar de forma anônima, essa ferramenta demonstrou ser um importante influenciador de doações e dos valores doados.

Ao analisar as listas de valores doados em cada campanha, verificou-se que os valores seguiam uma média, indicando que os doadores pautavam os montantes doados com base nos valores efetivados. Inclusive, em algumas campanhas observou- se o fenômeno do altruísmo competitivo apontado por Vugt et al., (2007), no qual os doadores competiram para poderem ficar bem posicionados no ranqueamento dos realizado na página de seu ente querido.

A utilização dos quadros com valores ranqueados e abertos ao público demonstrou eficiência no processo de utilizar a pressão social como fator especialmente agregador nas campanhas baseadas em contatos pessoais dos mobilizadores. Apesar de que, segundo as autoras Scharf, Payne e Smith (2015), esta abordagem pode ter seu efeito negativo caso a campanha tenha valores muito baixos como referência. Nas campanhas observadas, notou-se um efeito positivo, influenciando os doadores muitas vezes a doarem valores mais altos para demonstrar apreço ao organizador ou para se destacar do resto dos apoiadores.

Outra ferramenta analisada foi a funcionalidade de organizador e apoiadores das campanhas interagirem nos comentários da página de campanha. 
Foi verificado que em 95\% das campanhas, os organizadores e apoiadores interagiram com comentários e brincadeiras, reforçando um aspecto dialógico que permite maior interação entre organizador que lembra constantemente sua rede de apoiadores sobre sua angariação, aumentando as chances de divulgação e efetivas doações.

\subsubsection{Análise das ações promovidas pelos organizadores das campanhas da plataforma} Charity:Water.

A análise das ações dos organizadores para a promoção de suas campanhas da plataforma Charity:Water é proveniente das categorias identificadas na codificação e condensação dos dados coletados. Essas categorias apresentadas nos blocos avaliativos abordados no item 5.1 deste capítulo, serão melhor analisadas a seguir.

\section{a) Grau de personalização das campanhas}

Um dos pontos observados por alguns dos organizadores entrevistados (C2_E2, C2_E3, C2_E8, C2_E15, C2_E19,C2_E20) consiste no fato de as campanhas poderem ser criadas com rapidez, partindo de layouts com foto de capa, perfil e texto pré-determinados. Além disso, também podem ser personalizados conforme as preferências do organizador.

Nota-se portanto que o respectivo fluxo de usuário é pensado para os diferentes tipos de apoiadores. Existem apoiadores que não querem dedicar muito tempo para criar suas campanhas, enquanto outros querem personalizar mais. Tal abordagem possibilita que esses dois tipos de mobilizadores sejam contemplados, aumentando a probabilidade de criação de campanhas.

Analisando a composição geral das páginas de mobilização, conclui-se que plataforma não dá muita liberdade de personalização; o usuário não pode escolher o prazo de início e fim das campanhas, nem personalizar com vídeo próprio. As campanhas já são criadas com praticamente $90 \%$ do produto final, cabendo aos organizadores, se quiserem, personalizar foto de perfil, foto de capa e texto de campanha. 


\section{b) Grau de interação entre organizadores e rede de contatos}

Todos os organizadores divulgaram nas mídias sociais, mas diferiram na forma de divulgação. A utilização de e-mails e mensagens privadas dirigidas particularmente para cada pessoa de sua rede de contatos foi a prática que mais coincidiu entre as campanhas de sucesso.

Outro ponto destacado por um dos organizadores que mais angariaram na campanha foi a importância de fazer campanhas criativas, em que as pessoas se sentissem como decisivos no sucesso da angariação.

Como exemplo, o organizador C2_E4 realizou um matchfunding, estratégia na qual, na tentativa de motivar a rede de doadores, o organizador propôs que doaria 2 dólares para cada dólar angariado na campanha. Essa ação foi divulgada para seus amigos e contou com a ajuda da equipe da plataforma CW que, diante da criatividade da campanha, divulgou-a em suas mídias sociais de forma que inspire a própria rede direta da OSC. Ao analisar os comentários da referida campanha, foi possível verificar que a estratégia teve efeito:

Eu adoro ver meu dinheiro triplicar...melhor investimento que já fiz.

:) Feliz aniversário! (comentário de um doador da campanha C2_E4)

Eu adoro dobrar minhas doações! (comentário de um doador na campanha C2_E4)

Esse episódio evidenciou a importância e possibilidade de outra estratégia, como o matchfunding para estimular a interação da rede de contatos e converter doações. A mesma estratégia também fora aplicada em outras campanhas de aniversário (C2_E2, C2_E6, C2_E18) nas quais empresas parceiras da plataforma dobraram as doações realizadas por indivíduos nas campanhas $\mathrm{P} 2 \mathrm{P}$, potencializando-as ainda mais.

Ao questionar sobre as práticas das campanhas que angariaram abaixo do tíquete-médio, os organizadores justificaram que careceram de tempo para se dedicar à divulgação ou que se sentiram envergonhados de cobrar seus contatos 
de forma direta. Outros demonstraram passividade na interação com sua rede de contatos, como se pode identificar na afirmação de C2_E16: "se alguém viesse me pedir o que eu queria de presente de aniversário, eu mencionava a campanha".

Logo, foi perceptível que a postura do organizador em relação à divulgação das campanhas influencia a probabilidade de seu sucesso. Comportamentos de timidez, vergonha ou passividade têm alto grau inibidor de sucesso das campanhas $\mathrm{P} 2 \mathrm{P}$ visto que tais condutas direcionam a uma divulgação escassa e impessoal dos organizadores que são o principal canal para suscitar os doadores das campanhas.

\section{c) Eficiência do discurso do pedido}

A partir da análise dos texto das páginas de campanha e de publicações em mídias sociais, cedidas pelos próprios autores, evidenciou-se a diferença de comportamento em relação à clareza do pedido: enquanto alguns pediam de forma direta para sua rede, reforçando a importância dele, outros não chegaram a pedir a doação de forma explícita.

Nas campanhas que ficaram aquém do esperado, foi possível observar a incidência de fatores que atuaram como inibidores do call to action do pedido como no exemplo a seguir:

Se você não pode doar, não se preocupe! Mas agradeceria se você pudesse compartilhar este post, de forma que mais pessoas conheçam a organização e considerem a doação (C2_E17).

Ao relacionar com as entrevistas dos respectivos autores, os textos com inibidores de eficiência se explicaram nos relatos de seus autores, os quais expressaram que sentiram vergonha ou timidez de fazer um pedido mais proativo.

Excertos como o acima foram caracterizados como prejudiciais, pois possibilitam o free ride behavior (VESTERLUND, 2011), pelo qual, ao divergir o pedido de doação, apresentando outras formas de ajudar além das doações financeiras, muitas pessoas consideram ter cumprido seu papel de apoiar o 
amigo, esquivando-se para outras ações alheias à doação efetiva, como compartilhar ou curtir a publicação nas mídias sociais.

Portanto, considerando-se que o discurso de petição de doações não é uma habilidade praticada com frequência e conhecida pelos organizadores, o texto-padrão apresentado pela $\mathrm{CW}$ se apresentou como uma boa alternativa e mitigador de riscos, pois já é elaborado com fatores que estimulam o o leitor a doar. O texto providenciado para a campanha segue o padrão de: (a) estabelecer uma relação de empatia com a causa; (b) apresentar o problema; (c) apresentar a solução, explicando a atuação da OSC (d) fazer o pedido; (e) utilizar argumentos que estimulem a confiança do doador na legitimidade e eficiência da campanha.

Segundo Saxton e Zhuang (2013), esse discurso é eficaz, pois considera os dois tipos possíveis de apoiadores: o mais emocional - que normalmente se sensibiliza na apresentação do problema - e o mais racional - que questiona sobre a eficiência da OSC e o destino da sua doação.

\subsubsection{Classificação das práticas de mobilização dos organizadores das campanhas da plataforma Charity:Water.}

Em conjunto com o estudo realizado previamente, foi feita também uma classificação das práticas abordadas, com base nos quadros referenciados no item 5.1 desta dissertação. O intuito foi de aprofundar os resultados de cada campanha e analisá-los também de forma a contrastar resultados, assim trazendo um maior enriquecimento para o estudo. 
Quadro 12-Charity:Water: Classificação das práticas dos organizadores

\begin{tabular}{|c|c|c|c|c|}
\hline Código & Status & $\begin{array}{c}\text { Grau de } \\
\text { personalização }\end{array}$ & $\begin{array}{l}\text { Grau de } \\
\text { interação }\end{array}$ & $\begin{array}{l}\text { Discurso do } \\
\text { pedido }\end{array}$ \\
\hline C2_E1 & bem sucedida & 2 & 5 & 7 \\
\hline C2_E2 & bem sucedida & 1 & 4 & 6 \\
\hline C2_E3 & bem sucedida & 1 & 4 & 7 \\
\hline C2_E4 & $\begin{array}{l}\text { muitobem } \\
\text { sucedida }\end{array}$ & 3 & 10 & 5 \\
\hline C2_E5 & bem sucedida & 1 & 4 & 7 \\
\hline C2_E6 & $\begin{array}{l}\text { muitobem } \\
\text { sucedida }\end{array}$ & 2 & 5 & 9 \\
\hline C2_E7 & $\begin{array}{l}\text { muitobem } \\
\text { sucedida }\end{array}$ & 2 & 4 & 6 \\
\hline C2_E8 & bem sucedida & 2 & 5 & 7 \\
\hline C2_E9 & bem sucedida & 3 & 5 & 4 \\
\hline C2_E10 & bemsucedida & 3 & 6 & 2 \\
\hline C2_E11 & abaixodoTM & 1 & 2 & 7 \\
\hline C2_E12 & abaixodoTM & 2 & 2 & 3 \\
\hline C2_E13 & abaixodoTM & 3 & 2 & 4 \\
\hline C2_E14 & abaixodoTM & 1 & 2 & 7 \\
\hline C2_E15 & abaixodoTM & 2 & 3 & 7 \\
\hline C2_E16 & abaixodoTM & 2 & 1 & 1 \\
\hline C2_E17 & abaixodoTM & 2 & 1 & 4 \\
\hline C2_E18 & abaixodoTM & 2 & 3 & 7 \\
\hline C2_E19 & abaixodoTM & 1 & 2 & 7 \\
\hline C2_E2O & abaixodoTM & 1 & 2 & 7 \\
\hline
\end{tabular}

Fonte: A Autora.

Ao se analisar o Quadro 12, resultante de cada campanha, foi possível notar que a intensidade de personalização não indicou influência no desempenho financeiro das respectivas angariações, visto não ser apresentado um padrão lógico entre as campanhas de sucesso e abaixo da média.

Em contraposição, o grau de interação foi considerado o maior influenciador de sucesso das campanhas. Como se pode examinar as campanhas com nota acima de 3 nesse quesito foram bem-sucedidas.

Ao analisar as práticas realizadas para as campanhas foi possível notar que as campanhas bem-sucedidas se diferenciaram principalmente por práticas que vão além da publicação em mídias sociais, mas sobretudo consistem na abordagem pessoal da lista de contatos, adotada por $70 \%$ das campanhas bemsucedidas na plataforma $\mathrm{CW}$. 
Sobre a categoria "discurso do pedido", concluiu-se existir um potencial agregador - embora não determinante - da influência de discursos bemelaborados para aumentar o potencial de resultados das campanhas.

Como exemplo está o caso do organizador C2_E4, que recebeu uma das notas mais baixas no quesito do discurso, no entanto angariou 13 vezes mais do que o tíquete-médio de uma campanha da plataforma $\mathrm{CW}$, sendo considerada a campanha mais bem-sucedida na amostra selecionada de campanhas.

Em conjunto, um outro ponto que deve ser ressaltado consiste no fato de que o discurso do pedido foi um item que apresentou nota alta em quase todas as campanhas. A razão disso consiste no fato de a plataforma já possuir um textopadrão que apresenta muitos dos elementos considerados eficazes para a elaboração de um bom discurso de petição. Principalmente para os organizadores que justificaram a falta de tempo para a mobilização das campanhas, os textos de petição previamente prontos viabilizaram campanhas mais eficientes, prática que portanto foi considerada como benéfica estimular o aumento o tiquete-médio geral de angariação das campanhas.

$\mathrm{Na}$ análise e comparação das ações mobilizadas nas campanhas, também foi evidenciada uma aparente contradição, especificamente nos resultados da campanha C2_E7. Como pode ser observado em relação a outras mobilizações bem-sucedidas (como a C2_E8, por exemplo), a campanha C2_E7 apresentou as notas mais baixas nos três quesitos, embora seu resultado de angariação tenha sido substancialmente maior. Ao conversar com o entrevistado, este justificou seu resultado por ser de uma posição social mais alta, bem como seu círculo de amizades; profissionalmente, tinha várias empresas e até já tinha sido investidor social da organização no programa The Well - direcionado a investimentos de venture philanthropy - o que explicou a expressividade dos valores doados (haviam doações únicas de mais de 1.000 dólares).

Logo, é importante frisar que fatores como posição social do organizador atuam no sucesso das campanhas, apesar de ser um influenciador que não é passível de ser controlado pelos organizadores ou considerada uma boa prática, por isso não foi considerada nesta pesquisa. 


\subsection{Análise cross-case dos casos Eventos do Bem e Charity:Water}

Ao analisar os resultados obtidos nos estudos de caso apresentados, identificou-se que ambas as plataformas possuem diferenciado desenvolvimento tecnológico e abordagens da técnica P2P. Estes aspectos foram considerados positivos, visto que possibilitaram contrastar as abordagens diversificadas com os resultados das campanhas de cada caso, repercutindo em um maior enriquecimento da análise final da técnica P2P.

Primeiramente, é importante destacar que o tipo de público nas duas plataformas, coincide em jovens entre 20 e 35 anos, justamente a nova geração de e- filantropos indicada na bibliografia sobre o assunto (CLAYTON, 2009; MILLER, 2009; JILLBERT, 2003).

Também conhecidos por millennials, essa geração possui forte familiaridade com a comunicação, mídia e as tecnologias digitais. Se destacando pelo idealismo e orientação para a transformação social (NEXT GENERATION DONORS; 2013).

Algumas das características apontadas na geração de milennials foram identificadas nas entrevistas dos dois estudos de caso no que se refere ao desejo de envolvimento maior com a causa, importância dada ao retorno de impacto social, a naturalidade em divulgar seus projetos com as mídias sociais e a facilidade em doar online (MILLER, 2009).

Considerando as características e necessidades apresentadas, conclui-se que as plataformas online $\mathrm{P} 2 \mathrm{P}$ devem se adequar às exigências e aspectos deste tipo de público, o que resultará em campanhas $\mathrm{P} 2 \mathrm{P}$ mais eficientes e assertivas para a conversão de doações.

Isto traduz-se na importância de um material de comunicação, que utilize a inspiração e o storytelling em conjunto com ações que envolvam mais o organizador e sua rede de contatos na causa social a partir das campanhas promovidas.

Estes fatores, aliados a um bom design - inspirado nas mídias que o público- alvo mais aprecia - demonstrou um importante diferencial para os 
usuários devido à característica das campanhas pessoais do P2P relacionarem as páginas à própria imagem do organizador. Logo, os organizadores se sentem mais motivados a divulgar um material de qualidade que informe sua rede acerca de aspectos informativos da OSC, educacionais sobre a causa e também que estimule a segurança e eficiência das doações para a organização.

Em conjunto com um material de qualidade, dá se destaque especial para ferramentas que possibilitem e comprovem a segurança e a eficiência nas doações para o público de doadores e organizadores das campanhas. Ao analisar as abordagens da CW de ressaltar o "Modelo 100\%" e apresentar o impacto social por meio de relatórios digitais, percebe-se a importância destes elementos para influenciarem a segurança dos organizadores para divulgarem em sua rede de contatos e também argumento de persuasão para muitos dos mobilizadores convencerem sua rede a doarem para suas campanhas.

O mesmo fator de transparência emergiu na plataforma Eventos do Bem, pela qual os organizadores mencionaram que a insegurança e falta de transparência influenciou na sua experiência de doação e de sua rede de contatos. Para isso, diferentemente da CW que é um OSC com causa única, no caso da Eventos do Bem que atua com várias OSCs foram apresentados os atributos de segurança e transparência relativos à contabilidade aberta de todas as doações e status das doações das campanhas e o retorno de impacto social das campanhas para todos os respectivos apoiadores. Para isso, é necessário que, além da plataforma, a OSC beneficiada tenha um papel ativo, comprometendo-se no processo de retorno do impacto social das campanhas, além de proporcionarem material informativo e educativo sobre a entidade e a causa social.

Outro ponto considerado influenciador do sucesso das campanhas foi o “preço de doar" (WEISBROD; DOMINGUEZ, 1986), ou seja, o percentual do valor doado que é direcionado para a equipe promotora da causa social. Interessante verificar que esse fenômeno interferiu no processo de angariação das campanhas das duas plataformas, no entanto devido à diferença de abordagens, teve influência positiva e negativa para a angariação das campanhas.

Enquanto para a CW o fenômeno do "preço de doar" foi um motivador devido ao "Modelo 100\%", na EVB apresentou-se como um empecilho para 
doações, devido à taxa de intermediação cobrada.

Ao se investigar mais sobre o modelo da plataforma $\mathrm{CW}$, percebeu-se que este não consiste exatamente no redirecionamento direto ao beneficiário, mas numa alocação de recursos realizada de forma indireta nos gastos administrativos da OSC, revestindo a gestão de uma forma mais aceitável para os doadores. Tal abordagem revelou-se uma estratégia de modelagem de negócios relevante e agregadora à angariação de recursos pelas campanhas P2P e o "Modelo 100\%" foi indicado como um diferenciador de envolvimento por $90 \%$ dos entrevistados, organizadores das campanhas da CW.

Quanto à assessoria e acompanhamento do criador da campanha por ambas as plataformas, foi interessante observar que, apesar de a ação ter sido realizada de forma manual $(\mathrm{EVB})$ e automatizada $(\mathrm{CW})$, a abordagem não gerou diferencial quanto à satisfação de acompanhamento dos organizadores. Isso denotou que o modelo de acompanhamento por e-mails marketing e disponibilização de material de divulgação é passível de adquirir escalabilidade sem perder a qualidade e eficiência.

O mesmo pode ser realizado por meio de procedimentos automatizados que acompanhem o organizador da campanha durante todo o processo da angariação, economizando esforços e evitando o erro humano durante o processo.

Acerca das práticas mobilizadas pelos organizadores das campanhas, foi interessante observar que, apesar das diferenças entre as plataformas, as categorias relativas às práticas de mobilização das campanhas e sua eficiência se demonstraram convergentes, ressaltando ainda mais a existência de uma metodologia específica de abordar a técnica P2P para gerar bons resultados nas campanhas.

Em relação às práticas mobilizadas pelos apoiadores para a promoção das campanhas, evidenciou-se que as diferenças consistiram mais nos canais de comunicação utilizados, referentes à cultura específica dos países de origem das plataformas. Nas campanhas da plataforma EVB, foram utilizados principalmente os canais de divulgação Facebook e Whatsapp; em contraste, os 
organizadores da CW utilizaram, além do Facebook, o Twitter e mensagens de celular.

Todavia, em relação às práticas e estratégias de mobilização das campanhas, independentemente das diferenças culturais dos organizadores, foi possível estabelecer um claro paralelo e identificar padrões de comportamento convergentes em relação aos resultados positivos e negativos das angariações, dos quais emergiram as categorias agrupadas no Quadros 8, 9, 10, utilizados na classificação das campanhas nos dois casos.

Das três categorias analisadas - Grau de personalização, Grau de interação, Qualidade do Discurso do Pedido - ambas as campanhas reforçaram terem seus resultados mais diretamente relacionados ao grau de interação do organizador das campanhas com sua rede de contatos.

Além disso, entre as próprias ações de interação identificadas, também foi verificado que quanto mais personalizado o pedido do organizador e pessoal ao destinatário, maior a eficiência de resposta e conversão de doações.

As mídias sociais apresentaram-se como grandes portais de compartilhamento e divulgação massiva da proposta dos aniversários, mas, para realmente gerar resultado nas campanhas $\mathrm{P} 2 \mathrm{P}$, é necessário que o pedido seja pessoal. O potencial apoiador deve-se sentir chamado por seu conhecido, logo, um e-mail direto ou mensagem privada demonstrou fazer muita diferença para a angariação de doações, visto que também remove a justificação plausível de a rede de contatos afirmar não ter visto a publicação na mídia social.

Segundo Meer (2001), o pedido pessoal gera a pressão social para o potencial doador responder positivamente ao pedido de seu ente querido, para fortalecer a relação entre ambos. Além disso, conforme afirmado pelo funcionário C2_F6, diante da enorme gama de informações existentes na web, muitas vezes as mensagens- padrão não são notadas ou não geram significado para os internautas a ponto de serem lidas ou lembradas.

Em conjunto com a prática do pedido pessoal, destacou-se a utilização da pressão social em algumas das campanhas bem-sucedidas de ambas as plataformas. As abordagens de pressão social pelos organizadores consistiram na 
elaboração de uma estratégia de atuação e divulgação da proposta, exemplificada com práticas de sistematização e controle de respostas, repetição do pedido e agradecimento nas mídias sociais realizado de forma conscientemente orientada pelo mobilizador a fim de gerar notabilidade da sua rede de conhecidos e assim indiretamente pressioná-los a cooperarem com a sua campanha.

O aspecto de pressão social demonstrou também ser passível e ser potencializado pela plataforma, como ocorreu no caso da $\mathrm{CW}$, que apresentou de forma pública e ranqueada os nomes e valores dos doadores nas páginas das campanhas, também fornecendo a possibilidade do organizador agradecer e interagir com seus contatos por meio de mensagens nas próprias campanhas. Como resultado na análise das 20 campanhas selecionadas para esta pesquisa, notou-se que em $70 \%$ a abordagem gerou um efeito positivo de fenômenos como altruísmo competitivo (VUGT et al., 2007) e de valores-referência para doações (VERHAERT; VAN DEN POEL, 2011).

Apesar do grau de interação possuir mais influência na performance financeira das angariações, ao se contrastar o resultados das campanhas em ambas as plataformas, foi evidenciado nas campanhas com pontuações idênticas de grau de interação que a categoria “ qualidade do discurso do pedido" se apresentou como influenciadora da performance financeira, visto os diferentes resultados.

A partir da análise de conteúdo dos textos, vídeos e imagens de petição dos organizadores de ambos os estudos de caso concluiu-se que o pedido de doação precisa apresentar alguns aspectos de persuasão para os diferentes tipos de doadores, resumidos por Saxton e Zhuang (2013) nos tipos de doador emotivo e racional.

Desta forma, um bom pedido de doação deve mobilizar aspectos relativos a: (a) geração de empatia, muito abordada em ambientes digitais por meio do storytelling (GOODMAN, 2015); (b) proposições comuniquem a eficácia e a segurança do investimento das doações, por meio da transparência nos gastos e comprometimento de comunicação do impacto social gerado; (c) relação entre a campanha com algum aspecto pessoal do organizador, de forma a estimular o 
emocional da rede de relacionamentos do criador da campanha; (d) Apresentação da OSC e do problema social que é passível de ser amenizado por meio do patrocínio das ações da organização.

Ao verificar que muitos dos pedidos dos organizadores, principalmente da plataforma EVB, careciam de alguns destes elementos, foi apontada como uma boa prática para aumentar a performance das campanhas, a elaboração de um texto padrão contendo os aspectos mencionados para aumentar a qualidade do discurso, como ocorreu no caso da CW.

A presença de textos padrões também pode minimizar a influência de fatores inibidores da eficiência das campanhas - identificados em ambas as plataformas - como vergonha, timidez e falta de tempo para elaborar um bom discurso. Estes mesmos fatores inibidores demonstraram influência negativa no grau de interação, visto que atrapalham a realização de pedidos diretos dos organizadores para cada um de sua rede de contato. Todavia, apesar de sua influência, por ser muitas vezes decorrentes da própria personalidade dos organizadores, este é um aspecto que foi considerado impassível de ser controlado por boas práticas por isso as únicas ações mitigadoras são aquelas que automatizam ao máximo o contato dos mobilizadores com sua rede, com ações como a possibilidade de implementação de um texto padrão de qualidade, como fora mencionado.

Portanto, foram evidenciados os principais fatores influenciadores das campanhas $\mathrm{P} 2 \mathrm{P}$, possibilitando que o modelo de proposições de pesquisa fosse enriquecido com novas categorias, além de reforçar a influência das proposições que já foram apresentadas pelo referencial teórico.

Importante ressaltar que a categoria da personalização das campanhas, não demonstrou ter efeito direto em nenhuma das campanhas dos casos estudos. No entanto, considerando que as campanhas tem o aspecto pessoal - de serem ligadas à pessoa do organizador - extremamente relevante para o seu sucesso, a personalização foi considerada um aspecto mínimo e basilar para as campanhas P2P, apesar de não não influenciar diretamente na captação de recursos financeiros das mesmas.

Ademais, conforme verificado nesta análise cross-case, algumas 
categorias - como a interação dos organizadores com a sua rede de contatos possuem mais influência que outras nas campanhas, resultando no seguinte modelo da Figura 20 que, além de identificar práticas influenciadoras, apresenta de forma gráfica a intensidade da influencia das mesmas na performance financeira das campanhas $\mathrm{P} 2 \mathrm{P}$ online. 


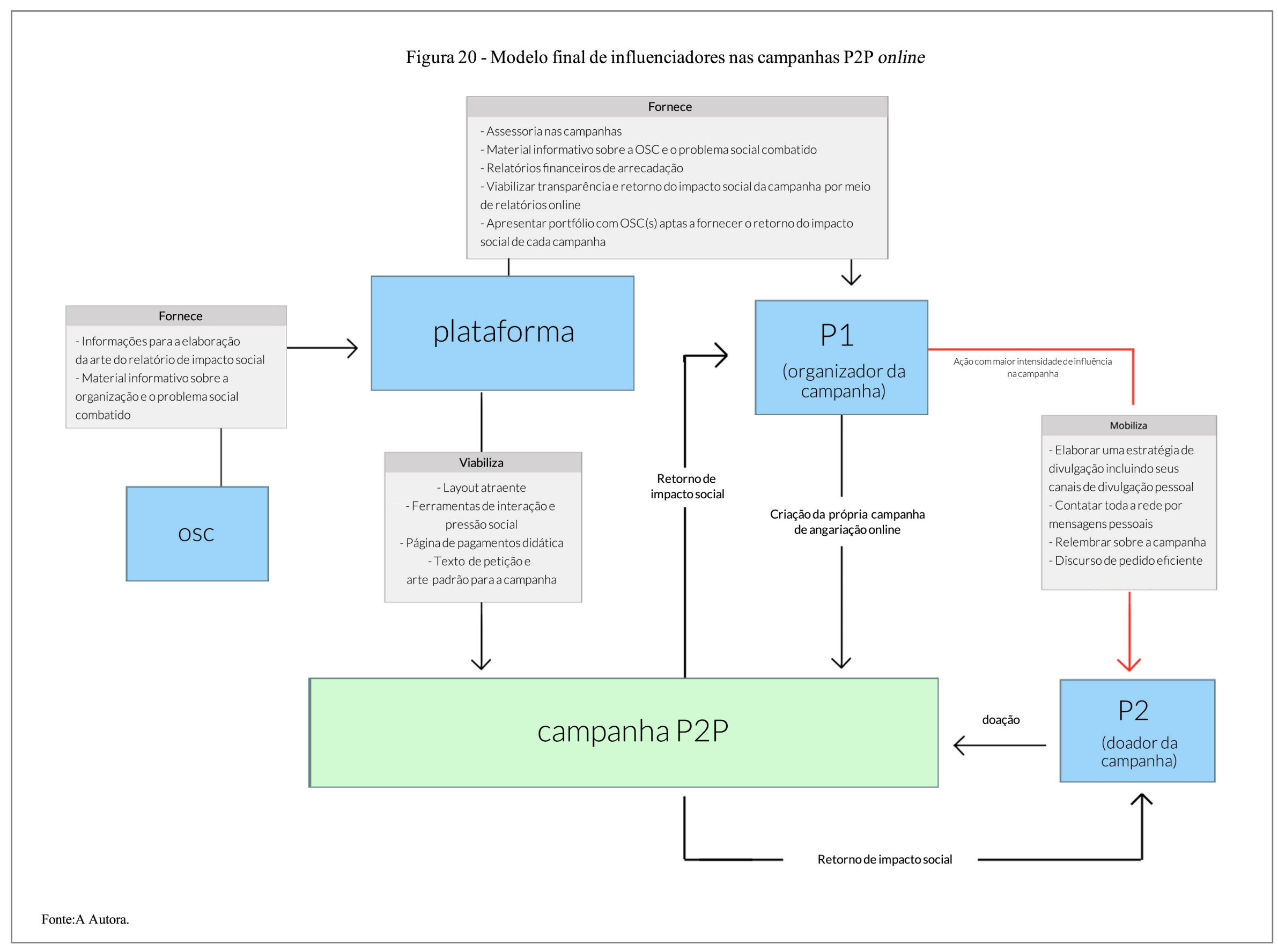




\section{CONSIDERAÇÕES FINAIS}

Neste capítulo, estão as considerações finais da presente pesquisa considerando seu objetivo geral, identificar influenciadores e boas práticas de captação de recursos das campanhas de angariação P2P online. Desta forma, retomam-se os objetivos propostos relacionando-os com o trajeto do estudo, resumindo os principais aprendizados e descobertas, culminando na resposta à questão principal desta pesquisa. Por fim, são apontadas as limitações e agenda para estudos futuros.

\subsection{Síntese e resposta à questão de pesquisa}

Com base nas proposições identificadas por meio do referencial teórico abordado, esta pesquisa se estruturou primeiramente no levantamento e análise das experiências da equipe promotora da startup Eventos do Bem, documentação das páginas de campanha e transcrições de 20 entrevistas com organizadores, dos quais emergiram os fatores influenciadores nas campanhas de aniversário da referida plataforma.

No estudo da dinâmica das campanhas, identificou-se a interferência da ação de três sujeitos: a OSC, a plataforma e os organizadores das campanhas $\mathrm{P} 2 \mathrm{P}$ online.

A inclusão da OSC como sujeito ativo no processo de angariação das campanhas foi um dos resultados que complementaram o modelo de proposições iniciais. A conclusão foi proveniente do estudo da experiências e demanda dos organizadores, que apontou a apresentação de material informativo de qualidade da OSC e da causa social, bem como a devolutiva do impacto social gerado pelas campanhas, como fatores importantes para o sucesso das angariações, visto que podem ser utilizados a fim de legitimar a seriedade da angariação e persuadir melhor a rede de contatos dos mobilizadores.

Em decorrência disso, devido à experiência da startup ao evidenciar o despreparo de algumas OSCs em suprir tais necessidades, uma das práticas importante é a seleção de organizações sociais qualificadas, a fim de assegurar a boa experiência dos usuários no processo.

Ademais, no decorrer da realização das campanhas, identificaram-se fatores relativos à segurança e transparência na prestação de contas, o manuseio da página de 
pagamentos, e estética das páginas de angariação. Conclui-se serem boas práticas a apresentação constante do status de angariação financeira das campanhas para os mobilizadores, maior investimento no Design, e páginas de pagamentos bastante didáticas a fim de se converterem mais donativos para os inexperientes em transações online.

Com relação à mobilização das campanhas pelos organizadores, nas entrevistas foram destacadas como práticas mais eficientes, realizadas pelas angariações consideradas bem- sucedidas, o pedido individual do organizador para cada conhecido da rede de contatos. O pedido deve se sistemático, explorar ao máximo toda a lista de contatos de mídias sociais, e-mail, agenda de telefone, entre outros. Em conjunto, para garantir a máxima exploração do potencial da rede, verificou-se a importância do planejamento e ativação dos potenciais doadores com ações e o follow up na cobrança das respostas.

O segundo estudo de caso abordado, das campanhas de angariação promovidas pela plataforma $\mathrm{CW}$, apresentou um cenário diverso, possibilitando o enriquecimento da análise visto que apresentou outras práticas e abordagens da plataforma acerca das campanhas de aniversário.

$\mathrm{Na}$ documentação e entrevistas com 20 organizadores e 6 funcionários da plataforma Charity:Water, destacaram-se as abordagens intituladas pela OSC como Dollars to Projects e "Modelo 100\%". Essas inciativas têm a proposta de garantir a comprovação de impacto social gerado pelas campanhas P2P por meio de relatórios digitais e gestão dos recursos investidos integralmente na atividade-fim. Notou-se que, como resultado, os mobilizadores das campanhas apresentaram sentimentos de confiança e eficácia na aplicação dos recursos angariados e relataram que se sentiram mais seguros não apenas em divulgar a campanha para sua rede de contatos como também convencê-los da eficiência da gestão de suas doações.

Além desse diferencial, os organizadores de campanhas entrevistados destacaram o design moderno, a disponibilização de material digital e comunicação por uso do storytelling como influenciadores da eficiência do discurso do pedido e aumento da aquisição de doações.

Por sua vez, ao cruzar com as práticas realizadas pelas campanhas, notou-se que o desempenho financeiro das angariações está diretamente ligado ao modo de interação dos organizadores com sua rede, destacando-se a petição pessoal e individual para seus 
conhecidos.

Como se pode notar, apesar de possuírem especificidades de abordagens principalmente das plataformas, em relação às práticas dos organizadores das campanhas, ao realizar o cross-case, foram identificados padrões de eficiência das ações dos mobilizadores na promoção das campanhas, bem como inibidores do sucesso.

Esses padrões foram condensados nas categorias de análise: grau de personalização das páginas de campanha; grau de interação, entre o organizador e sua rede de contatos; qualidade do discurso do pedido de doação.

Com exceção da categoria de personalização da campanha, que não demonstrou ter relação direta com as campanhas, o grau de interação e qualidade do discurso do pedido demonstraram atuar de forma significativa para o desempenho das angariações.

As práticas referentes à categoria 'grau de interação' consistem nas ações realizadas pelo organizador ao divulgar a campanha para sua rede pessoal. Como resultado da análise comparativa entre as 40 campanhas abordadas nesta pesquisa, foram apresentadas diversas ações de divulgação realizadas pelos organizadores, como festas de aniversário, abordagens criativas das campanhas, entre outros. Todavia, ao cruzar os dados das práticas efetivadas por campanha, notou-se que as mobilizações bem-sucedidas convergiam nas seguintes ações:

(a) pedidos individuais, enviados por mensagens privadas em aplicativos ou mídias sociais, e-mails, ou realizados ao vivo;

(b) exploração máxima de toda a rede de contatos: evidenciada ao se cruzarem práticas das campanhas e ao se investigar o grau de proximidade dos doadores das campanhas com organizadores. Nas 40 campanhas estudadas foi identificado que muitos apoiadores que não mantinham contato cotidiano com os mobilizadores, apesar de serem conhecidos de algum momento do passado;

Essas ações demonstraram ter seu grau de intensidade aumentado ao realizar abordagens como a de o mobilizador relembrar cada contato para doar para a sua campanha e reenviar mensagens pessoais para os contatos que não responderam ao pedido. A plataforma também pode auxiliar com ferramentas de pressão social implementadas à página online, 
como os quadros com as informações de doações abertas ao público, ranqueamento de doadores e a possibilidade de dialogia entre organizador e apoiadores na página de campanha, conforme se apresentou no caso da $\mathrm{CW}$.

Com as ações positivas, identificaram-se, em ambos os casos, fatores inibidores das ações de interatividade entre o organizador e a rede de contatos. Tais fatores consistem em comportamentos de timidez/vergonha do organizador em pedir proativamente para sua rede de contatos e falta de tempo para dedicar-se à divulgação.

Apesar de não ser possível evitar totalmente os inibidores, muitas vezes provenientes da própria personalidade dos criadores de campanha, destacaram-se ações realizadas pela plataforma $\mathrm{CW}$ que podem mitigar sua influência negativa na angariação financeira. Além da abertura das doações e ranqueamento dos doadores como se mencionou, a disponibilidade de textos-padrão automaticamente implementados nas campanhas garantiu a qualidade do discurso do pedido de pessoas que não interagiram tanto com sua campanha.

Além do grau de interação, destaca-se outra categoria considerada influenciadora do desempenho das campanhas: a qualidade do discurso de doação agrega fatores importantes para o convencimento da rede do organizador. Assim, com base nas proposições de Saxton e Zhuang (2013), as ações relativas ao convencimento e clareza no pedido das doações foram destacadas como boas práticas, enfatizando a apresentação de elementos emocionais e racionais nos textos e vídeos de mobilização.

Nos textos-padrão e outros elaborados pelos próprios organizadores das campanhas P2P de ambas as plataformas, foram destacados fatores influentes para um pedido eficiente de doação que:

(a) o organizador personalize o pedido com algum aspecto pessoal de sua vida, a fim gerar interesse dos apoiadores;

(b) o pedido seja claro e direto para o destinatário, estimulando somente a ação de doar, sem ter mais requisições;

(c) o organizador apresente aspectos informativos sobre a organização e educação sobre o problema social combatido e

(d) assegure a boa aplicação dos recursos e legitimidade da OSC oferecendo provas 
e oportunidades de envolvimento como visitas às organizações, prestação de contas e de impacto social das campanha.

Dessa forma, uma boa estratégia de campanha P2P online consiste em ações elencadas pela interação constante, proativa e individual do organizador com toda a sua rede de contatos, acompanhada por um discurso de qualidade para agregar - além da pressão social proveniente do pedido do conhecido - aspectos de persuasão e, assim, aumentar o potencial das campanhas.

Importante observar que, entre as duas categorias referidas, o grau de interação demonstrou ter maior influência no resultado das campanhas do que a qualidade do discurso de doação. O fenômeno é esperado dada ao fato de a natureza da captação de recursos $\mathrm{P} 2 \mathrm{P}$ ser centralizada nos promotores das campanhas online, os quais doam seus contatos pessoais para efetivar as doações.

Logo, pode-se afirmar que, nas campanhas P2P, o organizador caracteriza-se como o intermediador entre a OSC e uma rede de contatos inacessível para a entidade; assim, para o sucesso financeiro das campanhas, reforça-se a ação proativa de interação entre esse intermediador e sua rede de conhecidos.

Considerando-se o papel central dos organizadores para o sucesso das campanhas, constatou-se que, por sua vez, as plataformas de angariação P2P online devem possuir dois focos de atuação: o fornecimento de suporte técnico para as campanhas e auxílio à mobilização realizada pelos organizadores, empoderando-os com abordagens e boas práticas de captação online.

Como fornecimento de suporte técnico para as campanhas P2P online, destacaramse as práticas de investimento em design e manuseio das páginas que constituem o fluxo das campanhas P2P, com enfoque para a página de doação.

Quanto ao auxílio à mobilização realizada pelos organizadores, destacaram-se práticas como a garantia da transparência na aplicação de recursos e retorno do impacto social gerado pelas doações de cada campanha, disponibilização de ferramentas, material de divulgação da campanha online e, por fim, o acompanhamento pelo organizador em sua jornada de captação oferecendo, por meio de e-mails, boas práticas e inspirações que agreguem potencial à sua campanha. Ademais, por ser a natureza das campanhas de captação P2P baseada nos relacionamentos dos doadores, é também indicado o 
desenvolvimento de ferramentas que estimulem a pressão social, altruísmo competitivo e uma dialogia mais eficaz entre o organizador e cada indivíduo de sua rede de contatos.

Conclui-se, assim, como resultado deste estudo a identificação das boas práticas como integrantes de uma relação lógica e articulada entre ações da OSC, plataforma e organizadores, configurando um procedimento de angariação. Esse procedimento é apresentado na Figura 21, sendo indicadas as boas práticas mais determinantes para cada momento - pré-campanha, campanha e pós-campanha - das campanhas de angariação P2P. 
Figura 21- Boas práticas atuantes na jornada de angariação da campanha P2P online
1) Plataforma:
3) Plataforma:
6) Plataforma I 1
6) Plataforma

- Fornecer suporte técnico e Design de

qualidade;

- Selecionar OSCs capacitadas;

- Desenvolvimento de ferramentas de pressão social, dialogia e retorno do impacto social por meio de relatórios digitais;

I - Fornecer material de apoio para organizador;

- Assessoria na jornada de angariação com dicas de captação;

- Prestação de contas sobre o status das campanhas aos organizadores;

I - Fornecer textos de petição prontos para a divulgação da campanha;

I - Apresentar ferramentas de dialogia e pressão social nas páginas de campanha.
- Apresentação em relatório digital do impacto gerado e divulgação para a rede de doadores e organizador da campanha.

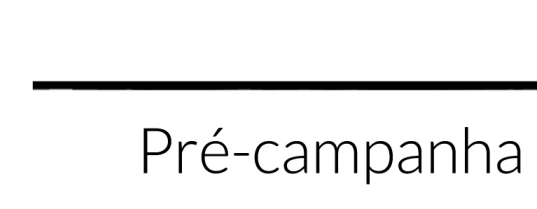

\section{2) OSC:}

- Elaboração de material informativo e educacional sobre a organização e a causa apoiada.

\section{Campanha}

\section{4) Organizadores das}

\section{campanhas P2P online}

I - Fazer uma lista contendo toda a sua rede de contatos de mídias sociais, agenda de telefone e e-mails;

I - Contatar todos os seus conhecidos de forma pessoal e individual; - Elaborar um discurso de pedido de doação de qualidade:

- Utilizar os meios de divulgação massiva para atualizar sua campanha;

- Agradecer em meio público a cada um de seus doadores;

- Reenviar e-mails e fazer o follow-up de respostas pendentes.

\section{Pós-campanha}

\section{5) OSC}

Fornecer informações sobre o investimento das doações da campanha tangibilizando o número de beneficiados e aprofundando no impacto social gerado, por meio imagens, vídeos e histórias.

Fonte: A Autora. 
Com base nas boas práticas e conclusões estabelecidas, pode-se identificar contribuições para a bibliografia, ainda recente, referente à e-filantropia e captação de recursos em geral.

Ao compararem essas boas práticas com o modelo de fatores influenciadores do processo decisivo de doar apresentado por Sargeant e Woodliffe (2007), nota-se que a dinâmica P2P apresenta uma outra forma de elaboração do processo visto que retira a OSC do foco de captação, sendo o organizador considerado a principal fonte de sua rede para doar. Apresentam-se, assim, novos motivadores do processo decisivo, como doações realizadas para agradar, garantir a manutenção do relacionamento, demonstrar apreço ao organizador da campanha, ou mesmo aquelas realizadas por conhecidos inspirados especialmente pela ação social inovadora. Logo, a "reação perceptiva", identificada no modelo de Sargeant e Woodliffe (2007) como identificação com a causa, transforma-se na identificação com o autor do pedido ou comunidade virtual apoiadora em comum. Nisso se destaca o fenômeno do friendraising apresentado por Smith et al. (2012).

Ademais, considerando-se os aspectos do novo doador indicados por Miller (2002) e Wallace (2002), a técnica demonstrou ser propícia para a nova geração de doadores online: o P2P apresentou uma outra forma de esses indivíduos contribuírem de forma protagonista com suas próprias iniciativas online, doando sua rede de contatos e inspirando sua comunidade a ajudar a causa social. Conforme a conclusão de alguns dos entrevistados, a técnica $\mathrm{P} 2 \mathrm{P}$ possibilitou que os criadores de campanha contribuíssem com a arrecadação de montantes muitas vezes fora do orçamento pessoal deles mesmos.

Dessa percepção, observou-se como resultante um acréscimo considerável de engajamento social e alegria dos organizadores proveniente da captação de recursos para as OSCs. Esse fenômeno demonstra também a expansão do conceito da alegria proveniente da doação direta apresentada por Andreone (1990), reforçando a existência da, já apontada pelas autoras Scharf, Payne e Smith (2015), "alegria correlacional de doação".

O fenômeno dessa "alegria correlacional de doação" consiste na satisfação de um indivíduo ao angariar uma doação de sua rede de contatos (SCHARF; PAYNE; SMITH, 2015), exemplificada pela afirmação do organizador C2_E12: "pra mim cada doação era um milagre! Eu não esperava nada”. Esse comportamento foi apresentado por outros organizadores, que se mostraram animados e surpresos com o impacto e montante de doações que obtiveram de sua rede de contatos. 
Identificado também pela pesquisa de uma plataforma P2P pelas autoras Scharf, Payne e Smith (2015), o fenômeno da "alegria correlacional" apresentou-se bastante poderoso e mais envolvente do que a própria "alegria de doação direta", visto que os organizadores quiseram ir além das doações diretas para o envolvimento maior em posteriores atuações administrativas e de captação de recursos das OSCs.

Dessa forma, também é possível notar contribuições à bibliografia sobre marketing de relacionamentos para OSCs, visto que o P2P apresentou uma nova forma de aprofundar o relacionamento entre a organização e seus apoiadores, a qual consistiu no compartilhamento de um momento pessoal e significativo na vida do organizador, como o de um aniversário. Graças à boa experiência vivenciada, organizadores como C1_E8 e C2_ E4 afirmaram que a campanha realizada constituiu um dos aniversários mais significativos de suas vidas, criando em consequência uma boa memória e experiência referente à OSC apoiada.

Pode-se concluir, portanto, que, além de seu resultado financeiro, as campanhas P2P online apresentaram-se como uma estratégia de aprofundamento de relações entre as OSCs e seus apoiadores, bem como a ativação de potenciais apoiadores por meio dos doadores pontuais das campanhas.

Esta pesquisa contribui, portanto, para abrir novas possibilidades de captação colaborativa que incluem os apoiadores das OSCs como sujeitos protagonistas no processo. Isso resulta numa nova dinâmica de razões para doar, e possibilidades de aproximação e envolvimento social de muitas pessoas que, por meio das campanhas de seus conhecidos, aproximam-se do terceiro setor pela primeira vez.

Considerando-se as características das campanhas P2P online apontadas, é possível vislumbrar um amplo caminho de possibilidades de inovação da técnica que, ao abrir a captação de recursos online para o poder colaborativo dos indivíduos, possibilita novas abordagens de angariação e, por sua vez, de envolvimento e transformação social.

\subsection{Limitação de pesquisa e agenda para trabalhos futuros}

Esta pesquisa apresentou como limitações aspectos relativos à estratégia metodológica abordada e trajeto de análise optado. 
A estratégia metodológica de estudos de caso múltiplos não permite a generalização de resultados. Além disso, devido ao fato de um dos casos selecionados ser um empreendimento da própria pesquisadora é possível que haja algum viés ao capturar dados com entrevistados com os quais a autora já teve contato, influenciado também na base de interpretação dos dados.

Quanto ao trajeto pelo qual se optou, é importante ressaltar que o foco da pesquisa se deu no objetivo de identificar ações que explicitamente podem ser mobilizadas pelos sujeitos atuantes no processo de mobilização das campanhas. Os doadores não foram considerados no processo, visto seu papel passivo de dependerem da ativação apropriada dos organizadores das campanhas.

No entanto, para aprofundar a dinâmica das campanhas de angariação P2P online e contribuir com mais elementos que enriqueçam a análise de influenciadores de desempenho das campanhas, sugere-se estudar especificamente os doadores das campanhas, a fim de se aprofundarem os motivos que os levaram a doar para as campanhas ou mesmo a não efetivarem as doações.

Também é importante ressaltar que o estudo se limitou a campanhas de aniversário, considerando seu sucesso de forma diretamente relacionada com o desempenho de angariação financeira. Notou-se que - além da diversidade de modalidades de campanhas P2P que valem a pena ser estudadas - o nível de envolvimento social gerado pelas campanhas foi um dos elementos emergentes, demonstrando que os resultados das campanhas P2P online vão além da angariação financeira pontual. Para compreender com maior profundidade tal fenômeno, como sugestão de continuidade de pesquisa, sugere-se o estudo das novas relações propiciadas pelas campanhas, tanto na perspectiva dos organizadores, quanto no das OSCs e doadores, especialmente no que se refere a fenômenos pós-campanha, evidenciados nas duas plataformas estudadas, de conversão de contatos ativados em campanhas $\mathrm{P} 2 \mathrm{P}$ em doadores recorrentes das OSCs.

Conforme a percepção da equipe das plataformas CW e EVB, apresentaram-se indícios de ser possível a elaboração de uma metodologia que busca a conversão de uma porcentagem de doadores, ativados constantemente nas diversas campanhas $\mathrm{P} 2 \mathrm{P}$, em apoiadores financeiros recorrentes para a OSC. Essa hipótese deve ser aprofundada em estudos e práticas de captação futuras, visto que sua confirmação apresentaria um grande avanço para o desenvolvimento dos métodos de angariação online e engajamento 
social de indivíduos.

Além dos pontos levantados, considerando-se o fenômeno da captação de recursos online como cada vez mais crescente na sociedade influenciada pela web, novos estudos devem ser realizados também sobre o próprio nascimento de inovações digitais na área, possibilitando o enriquecimento para o debate acerca de métodos e boas práticas que certamente, além da contribuição teórica, evidenciarão resultados práticos para o desenvolvimento do terceiro setor. 


\section{REFERÊNCIAS}

AgraWal, A.; CATAlini, C.; GOLDFARB, A. Some Simple Economics of Crowdfunding. In Innovation Policy and the Economy. Volume 14. 2013.

AKNIN ET. AL. Prosocial spending and well-being: Cross-cultural evidence for a psychological universal. Journal of Personality and Social Psychology, v.104, n. 4, p.635-652, 2013.

ALAN R. ANDREASON; PHILIP KOTLER, Strategic Marketing for Nonprofit Organizations, 6th ed., Prentice-Hall, 2003.

ALTHOFF T.; MIZIL C.; JURAFSKY D.; How to Ask for a Favor: A Case Study on the Success of Altruistic Requests, Proceedings of ICWSM, 2014.

AMOS O.M. Empirical analysis of motives underlying contributions to charity. Atlantic Economic Journal, v.10 p.45 - 52, 1982.

ANDREONI, J. Impure altruism and donations to public goods: a theory of warmglow giving. The Economic Journal, v.100, n.401, p.464-477, 1990.

ANDREONI, JAMES AND REGAN PETRIE. Public Goods Experiments Without Confidentiality: A Glimpse into Fundraising. Journal of Public Economics. Vol. 88, No. 7- 8, p. 1605-1623. July 2004.

ANDREONI, R.; J. RAO.; TRACHTMAN. Avoiding The Ask: A Field Experiment on Altruism, Empathy, and Charitable Giving. Journal of Political Economy, v.125, n. 3, p. 625-653, 2017.

The Power of Asking: How Communication Affects Selfishness, Empathy, and Altruism. Journal of Public Economics, 2011.

ANDRESEN, K. Impulse on the Internet: How Crisis compels Donors to Give Online. A Network for Good Study of Disaster Giving. The Network for Good, 2006.

ANDRESEN, K.; STRATHMAN B. Crafting the marketing strategy to make it happen. In: HART T.;GREENFIELD J.M. ; HAIJI S.D. People to People Fundraising - 
Social Networking and Web 2.0 for Charities. Hoboken, New Jersey: John Wiley \& Sons, Inc., 2007. Cap.5, p.104-124.

AUSTIN, J. E. Social Enterprise Series No. 18: The e-Philanthropy Revolution. Harvard Business School Working Paper, p.1-31, 2000.

. The E-Philanthropy Revolution is Here to Stay. Chronicle of Philanthropy, 2001.

BAJDE, D. Altruism and its relevance to consumer behavior and marketing: exploring the meaning of donation to charity: doctoral dissertation. Ljubljana: Ekonomska Fakulteta, 2006.

BAKER, T. Inspiring Donors Online: How Your Message Can Make People Feel Extraordinary. In: HART T.;GREENFIELD J.M. ; JOHNSTON, M. Nonprofit Internet Strategies - Best Practices for Marketing, Communications, and Fundraising Success. Hoboken, New Jersey: John Wiley \& Sons, Inc., 2005. Cap.9, p.111-118.

BALABANIS, G.; RUTH E.; STABLES; HUGH C. PHILLIPS. Market Orientation in the Top 200 British Charity Organizations and its Impact on Their Performance. European Journal of Marketing, v.31, n.8, p.583-603, 1997.

BARDIN, L. Análise de conteúdo. Lisboa: Edições 70, 2006.

BEKKERS, R.; WIEPKING, P. A literature review of empirical studies of philanthropy. Nonprofit and Voluntary Sector Quarterly v.40 , n.5, p.924-973. 2011.

BENDAPUDI; et al. Enhancing Helping Behavior: An Integrative Framework for Promotion Planning. Journal of Marketing, vol. 60, p.33-49, 1996.

BENNETT, R. Implementation processes and performance levels of charity internet fundraising systems, Journal of Marketing Channels, Vol. 12, No. 3, pp.53-77, 2005.

Impulsive donation decision during online browsing of charity websites. Journal of Consumer Behavior, vol. 8, p.116-134, 2009.

BHATTARCHARYA, C.; BOLTON, R. Relationship Marketing in Mass Markets. In J. Sheth and A Parvatiyar (eds.), Handbook of Relationship Marketing. Thousand Oaks, 
Calif.: Sage, 2005.

BLAU, A. Internet giving: not the perfect revolution. The Chronicle of Philanthropy, vol. 14, n. 2, p.85-86, 2001.

BOEDER, P.; HOHN B. Fundraising on the Internet: On-Line Strategies for Nonprofit.Organizations. Encyclopedia of Library and Information Science 1. 2004

BOLES,B.. Technology's Role in the Nonprofit Sector: Increasing Organizational Effectiveness and Efficiency through Technology Innovations. Columbia Social Work Review, v. 4, p. 69-79, 2013.

BONBRIGHT, D. What do we need to know? The information we need to make social investment decisions. Alliance Magazine, Dez. 2007.

BORCK, R., FRANK, B. \& ROBLESDO, J. R. An empirical analysis of voluntary payments for information goods on the Internet. Information Economics and Policy, v.18,p.229-239, 2006.

BRAITERMAN et al. Peer-to-Peer Fundraising Study, Blackbaud, 2016. Disponível em: https://goo.gl/vLQUn5 acesso em 10/06/2017.

BRAITERMAN et al. Peer-to-Peer Fundraising Study. Key Performance Indicators for Online Participants and Teams by Loyalty, Donation Level, and Fundraising Performance. Blackbaud, 2015. Disponível em: https://goo.gl/UyrChD acesso em $10 / 06 / 2017$.

BRESSAN, R. T. Dilemas da Rede: WEB2.0, conceitos, tecnologias e modificações. Universidade Federal de Juiz de Fora. 2007.

BRUCE, I. Marketing Need. London: ICSA Publishing, 1994.

BURNETT, J. J.; WOOD, V. R. A proposed model of the donation decision process. Research in Consumer Behavior, v.3, p.1-47, 1988.

BURNETT, K. Relationship Fundraising. London: White Lion Press, 1992 and 1998. CARROLL, J. Net makes giving easier. CA Magazine, n.136, ano 8, vol. 12, 2003.

CASTELLS, Manuel. A sociedade em rede. São Paulo: Paz e Terra, 1999. v. 1.

CASTILlO, M.; R. PETRIE ;C. WARDELL. Fundraising Through Online Social 
Networks: A Field Experiment on Peer-to-Peer Solicitation. Journal of Public Economics v.114, p. 29-35, 2014.

CHEN, el al. Social Comparisons and Contributions to Online Communities: A Field Experiment on MovieLens. American Economic. Review, v. 100, n.4, p.1358-1398 2010.

CHUNG, H.; ZHAO, X. Effects of perceived interactivity on Web site preference and memory: Role of personal motivation. Journal of Computer-Mediated Communication, v.10 n.1, 00-00. 2006

CLAYTON, A. Good people: a work in progress. Int. J. Nonprofit Volunt. Sect. Mark, v.14, p. 387-393, 2009.

COYLE, J. R.; THORSON, E. The effects of progressive levels of interactivity and vividness in web marketing sites. Journal of Advertising, v.30, n.3, p.65-77. 2001.

CRESWELL, J.W. Projeto de pesquisa: métodos qualitativo, quantitativo e misto. 3 ed. Porto Alegre: Artmed, 2010.

CUGELMAN, B.; THELWAL1, M.; DAWES, P. Online interventions for social marketing health behavior change campaigns: A meta-analysis of psychological architectures and adherence factors. Journal of Medical Internet Research, v.13, n.1, e.17, 2011.

DAWSON S. Four motivations for charitable giving: implications for marketing strategy to attract monetary donations for medical research. Journal Health Care Mark, v.2 p.31- 71988 .

DEJONG, W.; ARVO J. Oopik. Effect of Legitimizing Small Contributions and Labeling Potential Donors as 'Helpers' on Responses to a Direct Mail Solicitation for Charity. Psychological Reports, v. 71, p 923-928, 1992.

EISENHARDT, K.M. Building theories from case study research. Academy of management review, v.14, n.4, p.532-550, 1989.

EWING, R.; et.al. Economics, Marketing Segmentation and Recruiting: Targeting Your Promotion to Volunteers' Needs. Journal of Nonprofit and Public Sector Marketing, v.10, n.1, p.61-70, 2002.

FIGUEIREDO, C.Fernanda. Estudo sobre as particularidades e a capacidade de 
formulação e execução de estratégias de organizações da sociedade civil. Dissertação

(Mestrado). 2013.160f. Faculdade de Economia Administração e Contabilidade,Universidade de São Paulo São Paulo, 2013.

FLICK, Uwe. Introdução à pesquisa qualitativa. Tradução Joice Elias Costa. 3.ed. Porto Alegre: Artemed, 2009.

FRASER, C.; HITE, R.E; SAUER, P.L. Increasing contributions in solicitation campaigns: The use of large and small anchorpoints. Journal of Consumer Research v.15, n. 2, p.284-287, 1988.

FREY, B.; MEIER, S. Social Comparison and Pro-Social Behavior: Testing Conditional Cooperation in a Field Experiment. American Economic Review, v.94, n.5, p. 1717$1722,2004$.

FULTZ J. C.; el al. Social evaluation and the empathy altruism hypothesis. J Pers Soc Psychol, v.50, p.761-9, 1986.

GARECHT, J. How to Raise More Money for Any Non-Profit: The Definitive Fundraising Guide Paperback. Publisher: Fundraising Authority Press, 2013.

GENESKE, J. Digital Storytelling for social impact. Rockfeller Foundation, 2014. GIL, A.C. Como elaborar projetos de pesquisa. 6 ed. São Paulo: Atlas, 2012.

GIVING USA.; NCCS. Nonprofit fundraising study: Covering charitable receipts at U.S. nonprofit organizations in 2011, 2012. Disponível em: https:/goo.gl/QZJgnJ acesso em $10 / 06 / 2017$.

GODIN, S. Permission Marketing, Simon \& Schuster, 1999.

Flipping the Funnel: Give Your Fans the Power to Speak Up. Irvington, N.Y.:

Do You Zoom, 2006.

GOECKS, J. et al. Charitable Technologies: Collaborative Computing in Nonprofit Fundraising. In Proceedings of the 2008 ACM Conference on Computer-Supported Cooperative Work (CSCW '08), 2008.

GOODMAN, A. Telling The Story of Your Organization \& Why It's So Important.

Disponível em: https://goo.gl/Zb24k7, acesso em 10/06/2017. 
. Storytelling as Best Practice, Seventh Edition. The Goodman Center, Los Angeles, 2015.

GORDON, T.P.; KNOCK, C.L.; NEELY, D.G. The role of rating agencies in the market for charitable contributions: an empirical test. J. Account. Public Policy v.28, p.469-484, 2009.

GROBMAN, G. Nonprofit Guide to the Internet. Harrisburg, Pa: White Hat Communications, 2000.

GUY B.S; PATTON W.E. The marketing of altruistic causes: understanding why people help. Journal of Services Marketing, v.6, n.1, p. 19-31, 1989.

HACKLER, D.; SAXTON, G. D. The strategic use of information technology by nonprofit organizations: Increasing capacity and untapped potention. Public Administration Review, v.67, n.3, p.474-487, 2007.

HAGEL, J.; ARMSTRONG, A. G. Net Gain Expanding Markets Through Virtual

HAGENBUCH, D. Easy Ways to Turn Your Supporters in to Fundraisers. Nonprofit World, v.25, n.1,p. 22- 23, 2007.

HANDY, C. Trust and the Virtual Organization. Harvard Business Review , v.73, n.3, p. $40-50,1995$.

HARBAUGH, W. T. What do donations buy? A model of philanthropy based on prestige and warm glow. Journal of Public Economics, v. 67, n.2, p.269-284, 1998.

HARRISON, S. Scott's story. 2006. Disponível em: https://goo.gl/Rcgp4t acesso em $10 / 06 / 2017$.

;. ROSE, D. Inspiring Story Behind charity:water - Interview with Founder and CEO Scott Harrison. 2012. Disponível em: https://goo.gl/pGTzCJ acesso em 10/06/2017. ;_ _ _ _ HAJI, S. D. People to People Fundraising: Social Networking and Web 2.0 for Charities. New York: John Wiley and. Sons, Inc., 2007. ; .; JOHNSTON. Nonprofit Internet Strategies: Best Practices for Marketing, Communications, and Fundraising Success. New York: John Wiley and. Sons, Inc., 2005. 
HART, T.R., ePhilanthropy: Using the Internet to Build Support, International Journal of Nonprofit and Voluntary Sector Marketing,v.7, n.4, p. 353-360, 2002.

HOLT, G. R.; HORN, G. Taking donations in cyberspace. The Bottom Line, v.18, n.1, p.24-28, 2005.

HON, L.; GRUNIG, J.E. Guidelines for measuring relationships in public relations. Gainsville, FL: Institute for Public Relations, 1999. Disponível em: https://goo.g1/9Mxj3v acesso em: $16 / 07 / 2017$.

HOWE, J. The Rise of Crowdsourcing. Disponível em: http:/goo.gl/0wmKnk. Acesso em: 15/04/2017, 2006.

IDIS - Instituto de Desenvolvimento do Investimento Social. Pesquisa Doação Brasil. 2015. Disponível em: https://goo.gl/qY2Ta2 acesso em 10/06/2017.

ILCHMAN, W. F.; KATZ, S. N.; QUEEN, E. L. Philanthropy in the world's traditions. Bloomington, Indianapolis: Indiana University Press, 1998.

INGENHOFF, D., \& KOELLING, M. The potential of web sites as a relationship building tool for charitable fundraising NPOs. Public Relations Review, v.35, p.66-73, 2009.

JENKINS, H. Confronting the Challenges of Participatory Culture: Media Education for the 21st Century. Chicago, IL: MIT Press, 2009.

, H. Cultura da convergência. 2. ed. São Paulo: Aleph, 2009.

JILLBERT, J. E-philanthropy as a New Way to Gain Online Donation: A Review of Charitindey Websites. ITIRA Conference Proceedings, December 2003.

JOHNS Hopkins. (2010). The nonprofit technology gap - Myth or reality? (Communiqué No. 20). Baltimore, MD: Author. TechSoup Global. cloud computing survey. San Francisco, CA: Author, n.20 2012.

JOHNSTON M. The Fund-raiser's Guide to the Internet. Wiley: New York, 1999. . Annual Giving: Acquiring, Cultivating, Soliciting, and Retaining Online Donors. In: HART T.;GREENFIELD J.M. ; JOHNSTON, M. Nonprofit Internet Strategies Best Practices for Marketing, Communications, and Fundraising Success. Hoboken, New 
Jersey: John Wiley \& Sons, Inc., 2005. Cap.14, p.176-196.

K. BRANSTON; L. BUSH. The nature of online social good networks and their impact on non-profit organization and users, Prism, v.7, 2010.

KANG, S.; NORTON, H. E. Nonprofit organizations: use of the World Wide Web: are they sufficiently fulfilling organizational goals? Public Relations Review, v.30, 2004.

KELLY, K. S. Effective fund-raising management. Mahwah, NJ: Lawrence Erlbaum Associates, 1998.

KELLY, R. E.; LEWIS. P.E. T. Household demand for internet connection. Journal of Media Economics, v. 14, n.4, p. 249-65, 2001.

KELOGG FOUNDATION. e-Philanthropy v2.001 From Entrepreneurial Adventure to an Online Community. 2001. Disponível em: https://goo.gl/JepjDK acesso em $10 / 06 / 2017$.

KIMERY, K.M.; MCCORD, M. Signals of Trustworthiness in E-Commerce: Consumer Understanding of Third-Party Assurance Seals. Journal of Electronic Commerce in Organizations v.4, n.4, p. 52-74, 2006.

KING.P.; NOBLE N.; Peer-to-Peer fundraising and community building. In: HART T.;GREEnfIELD J.M. ; HAIJI S.D. People to People Fundraising - Social Networking and Web 2.0 for Charities. Hoboken, New Jersey: John Wiley \& Sons, Inc., 2007. Cap.4, p.83- 102 .

KLEIN, K. Fundraising for Social Change. 5 ed. San Francisco: Jossey-Bass, 2007.

KOLB, A. D. Experimental Learning: Experience as the Source of Learning and Development. New Jersey: Prentice Hall, 1984.

KRAKAUER, P. V. C.; MARQUES J. A.; ALMEIDA M. I. R. Mestrado Profissional em Administração: diretrizes na elaboração de projetos. In: ENANPAD - XXXIX ENCONTRO DA ANPAD, 13 a 16/12/2015.

LEDINGHAM, J. A. Explicating relationship management as a general theory of public relations. Journal of Public Relations Research, v.15, p.181-198, 2003.

LEE, C.; et all. E-commerce Disruptive Innovations in Charity and Non-profit Fund Raising. Journal of Strategic ECommerce, 2007. 
LEIDER, S. ET AL. Directed altruism and enforced reciprocity in social networks. The Quarterly Journal of Economics, v.124, n.4, p. 1815-1851, 2009.

LEMOS, A. LÉVY, P. O futuro da internet: Em direção a uma ciberdemocracia planetária. São Paulo: Paulus, 2010.

LESKOVEC, D. How to Collect Donations: Conceptual Review and Implications for Online Non-profit Information Goods Providers. Akademija, 2008.

LÉVY, P. A inteligência coletiva: por uma antropologia do ciberespaço. 4. ed. São Paulo: Loyola, 2003.

LÉVY, P. Cibercultura. 2. ed. São Paulo: Editora 34, 2000.

LOVEJOY, K., \& SAXTON, G. D. Information, community, and action: How nonprofit organizations use social media. Journal of Computer-Mediated Communication, v.17, p.337-353, 2012.

MACMILLAN, KEITH, KEVIN MONEY, ARTHUR MONEY, AND STEVE DOWNING, Relationship Marketing in the Not-for-profit Sector: An Extension and Application of the Commitment-trust Theory. Journal of Business Research, v.58, n.6,p. 806-18, 2005.

MAlHOtRA, N.K. Pesquisa de Marketing: uma Orientação Aplicada. Porto Alegre: Bookman, 2011.

MARTINS, G. A.; THEÓPHILO, C. R. Metodologia da investigação científica para ciências sociais aplicadas. São Paulo: Atlas, 2007.

MASSOLUTION, Crowdsourcing.org. 2015CF , Industry Report,2015.

MCNUTT, J.G.; BOLAND, K.M. Electronic advocacy by nonprofit organizations in social welfare policy. Nonprofit Volunteer Sector Quart. v.28, p. 432-451, 1999.

MEER, J.; ROSEN; HARVEY S. The ABCs of charitable solicitation. Journal of Public Economics, Elsevier, vol. 95, n.5, p. 363-371, 2011.

MEINERT, et al. Privacy Policy Statements and Consumer Willingness to Provide Personal Information. Journal of Electronic Commerce in Organizations, v.4, n.1, p. 1$17,2006$.

MERCHANT A.; FORD J.; SARGEANT A. Charitable organizations' storytelling 
influence on on donors' emotions and intentions. Journal of Business Research, vol. 63, 754-762, 2010.

MICHEL, G.; RIEUNIER,S. Nonprofit brand image and typicality influences on charitable giving. Elsevier, v. 65, n.5, p. 701-707, 2012.

MILLER, B. Community fundraising 2.0 - the future of fundraising in a networked society?. Int. J. Nonprofit Volunt. Sect. Mark, v.14, p.365-370, 2009.

MILLER, L. Charities hope 9/11 inspires 'e-philanthropy.' USA Today, Life, pg. 4D. March 19, 2002.

MITRA, T.; GILBERT, E. The Language that Gets People to Give: Phrases that Predict Success on Kickstarter. In Proc. CSCW'14, 2014.

MOGUS, J.; LACROIX, P. Building Your Brand Online. In: HART T.;GREENFIELD J.M.

; JOHNSTON, M. Internet Strategies - Best Practices for Marketing, Communications, and Fundraising Success. Hoboken, New Jersey: John Wiley \& Sons, Inc., 2005. Cap.8, p.100- 108 .

MOON, S.; AZIZI, K. Finding Donors by Relationship Fundraising. Journal of Interactive Marketing, v. 27, n.2, p.112-129, 2013.

NETWORK FOR GOOD. 2013 Year in Review: The Digital Giving Index. 2014. disponível em: https://goo.gl/DtIKA3, acesso em 13/05/2017.

NETWORK FOR GOOD. The young and the generous: A study of \$100 million in online giving to 23,000 charities. 2007. Disponível em: https://goo.gl/bwsRnp acesso em $11 / 06 / 2017$.

NEXT GENERATION DONORS. 21/64 e Dorothy A. Johnson Center for Philanthropy, 2013. Disponível em https://goo.gl/k6gTcN acesso em 11/06/2017.

NORTH, M.; GILL, J. E-Philanthropy. Changing our way of Giving: a briefing by Greenstar Foundation, 1999.

NTEN \& M+R STRATEGIC SERVICE. . eNonprofit benchmarks study. Disponível em: http://www.ebenchmarksstudy.com/ acesso em 11/05/2017. 
O'ROURKE, M.; BALDWIN, G. How the Internet has changed volunteering: Findings from a VolunteerMatch user study. Journal of Volunteer Administration, v.22, n.3, p.1622, 2004.

OLIVEIRA FILHO, G. KYAMA, R., COMINI, G. Impacto Social in: Barki et al Negócios Sociais no Brasil. São Paulo: Peirópolis, 2012.

OLSEN, M.; et al. E-relationship development strategy for the non-profit fundraising professional. International Journal of Non profit and voluntary Sector, v.14, p.101-109, 2001 .

PATTON, M.Q. A holistic perspective. In: Qualitative evaluation and research methods.

2 ed. London: Sage, 1990.

PAYNE A. et al. Survey of Online Fundraisers, Sponsors, andDonors - Summary of Responses Centre for Market and Public Organisation, 2012.

PAYNE, A.; HOLT, S. Diagnosing Customer Value: Integrating the Value Process and Relationship Marketing. British Academy of Management, v.12, p.159-182, 2001.

PEPPERS, D.; ROGERS, M. The One to One Future, Currency Bantam Doubleday Dell: New York, NY,1993.

POLLACH, I.; TREIBLMAIER, H.; FLOH, A. Online Fundraising for Environmental Non-profit Organizations. 38th Hawaii International Conference on System Sciences, Los Alamitos: IEEE Computer Society, 2004.

. Online Fundraising for Nonprofit Organizations. Transactions on Advanced Research, v.1, n.2, p.56-62, 2005.

POLONSKY, M.; SARGEANT, A. Managing the donation service experience. Nonprofit Management and Leadership, v.17, n.4, p. 459-476, 2007.

PORTER, M.E. \& KRAMER, M.R.Philanthropy's new agenda: Creating value. Harvard Business Review, p.121-130, 1999.

. The competitive advantage of corporate philanthropy, Harvard Business Review, Vol. 80, No. 12, pp.57-68, 2002.

PRACEJUS J.W.; OLSEN D. G. The role of brand/cause fit in the effectiveness of cause- related marketing campaigns. Journal of Business Research, v.57, n.6, p.635-40. 
2004.

R. B. CIALDINI. Influence: Science and Practice. Boston: Allyn \& Bacon, 2001.

REINGEN, P. H. On Inducing Compliance With Requests. Journal of Consumer Research, v.5 p.96-102, 1978.

REIS, T.; CLOHESY, S. E-philanthropy, volunteerism and social changemaking: A new landscape of resources, issues and opportunities. Battle Creek, MI: W.K. Kellogg Foundation, 2000.

RICHERT AJ. Living stories, telling stories, changing stories: experiential use of the relationship in narrative therapy. J Psychother Integr, v. 13n.2 ,p.188-210, 2003.

RIES, Eric. Lean Startup. Prime books, 2012.

ROTMAN, D.; et al. From slacktivism to activism: participatory culture in the age of social media. In CHI'11 Extended Abstracts on Human Factors in Computing Systems, ACM, p.819-822, 2011.

RYKER, R.; KHURRUM, M.; BHUTTA, S. Online Privacy Policies: An Assessment of the Fortune Global 100. Journal of International Technology and Information Management, v.14, n.1, p.15-24, 2005.

SAMU S; WYMER $\mathrm{W}$. The effect of fit and dominance in cause marketing communications. Journal of Business Research, v.62, n.4, p.432-40, 2009.

SARGEANT, A. Web Based Fund Raising: Is Anyone Making Any Real Money? Fund Raising Management, v.32, n.8, p.20-23, 2001.

Relationship fundraising: How to keep donors loyal. Nonprofit Management \& Leadership, v. 12, n.2, p. 177-192, 2001b.

. Charitable Giving: Towards a Model of Donor Behavior. Journal of Marketing Management, v.15, p.215-238,1999.

. Marketing Management for Nonprofit Organizations. 2ed, New York: Oxford University Press, 2005.

; JAY, E. Fundraising Management: Analysis, Planning and Practice. Ö Routledge, Londres. 2004.

; WOODLIFFE, L. Gift giving: an interdisciplinary review. International Journal 
of Nonprofit and Voluntary Sector Marketing, v.12, p.275-307, 2007.

SAXTON, G. D. et al. New dimensions of nonprofit responsiveness: The application and promise of Internet-based technologies. Public Performance and Management Review, v.31, p.144-173, 2007.

;) WANG, L. The social network effect: The determinants of giving through social media. Nonprofit and Voluntary Sector Quarterly, v.43, n.5, p.850-868, 2014.

.; et al. Web Disclosure and the Market for Charitable Contributions. Journal of Accounting and Public Policy, v. 33, 2014.

SCHARF, K.; PAYNE, A.; SMITH, S. Online Fundraising. The Perfect Ask? CAGE Discussion Paper No. 194, 2015.

SCHWARTZ S. Normative influences on altruism. In: Berkowitz L, editor. Advances in experimental social psychology. New York, NY’ Academic Press; p. 221- 79, 1977.

SHANG, J.; CROSON, R. Field Experiments in Charitable Contribution: The Impact of Social Influence on the Voluntary Provision of Public Goods. The Economic Journal, v.119, n.540, p. 1422-1439, 2008.

SHENG-SHU.; JACK SHEN. The e-way to philanthropy : how nonprofits can use information technology Format: Book; Published: New York, N.Y. : Center for Philantropy research, 2001.

SIMONSON, I.; DROLET, A. Anchoring effects on consumers willingness to pay and willingness-to-accept. Journal of Consumer Research,v.31, p.681-690, 2004.

SINGH, A.; MIDDLETON S. Digital Giving: Modernising Gift Aid; Taking Civil Society into the Digital Age. Charities Aid Foundation, 2010. Disponível em:

$<$ http://www.respublica.org.uk/articles-and-publications $>$, acesso em 10/06/2017.

SMITH, M. The Mellman Group for Craver. 1999.

SOETEVENT, A. Anonymity in Giving in a Natural Context - A Field Experiment in 30 Churches. Journal of Public Economics v.89, p. 2301-2323, 2005. 
STEIN, M. Nonprofits and ECommerce: An interview with Gary Grobman. 2001.

TAPSCOTT, D. Wikinomics: como a colaboração em massa pode mudar o seu negócio / Don Tapscott, Anthony D. Williams; tradução de Marcello Lino. - Rio de Janeiro: Nova Fronteira, 2007.

TINDALL, N. T. J. Fund-raising models at public historically Black colleges and universities.

Public Relations Review, v.33, n.2, p.201-205, 2007.

TREIBLMAIER, H.; POLLACH, I. Drivers and Inhibitors of Online Donations to Nonprofit Organizations. Journal of International Technology and Information Management, vol 17, n. 2, p.85-98, 2008.

VAN NOORT, G.; VOORVELD, H. A.; VAN REIJMERSDAL, E. A. Interactivity in brand web sites: Cognitive, affective, and behavioral responses explained by consumers' online flow experience. Journal of Interactive Marketing, 26, 223-234, 2012.

VAN VUGT, et al. Competitive altruism: a theory of reputation-based cooperation in groups. In: Dunbar, Robin and Barrett, Louise, eds. Oxford Handbook of Evolutionary Psychology. Oxford Library of Psychology . Oxford University Press, Oxford, 2007.

VANHUSS,k.; FULTON,O. Dollar Dash: The Behavioral Economics of Peer-toPeer Fundraising, Richmond: Turnkey P2P, Inc., 2017.

VERHAERT, G. A.;VAN DEN POEL, D. Improving campaign success rate by tailoring donation requests along the donor lifecycle. Journal of Interactive Marketing, v.25, p.51-63, 2011.

VESTERLUND L. Why do people give. In: The nonprofit sector: A research handbook. v.2, p.168-190, 2006

WAGNER, L. The 'new' donor: creation or evolution?. Int. J. Nonprofit Volunt. Sect. Mark. v. 7, p.343-352, 2002.

WALLACE, N. Outlook for online donations is cloudy, experts say. In: The Chronicle of Philanthropy, Vol. 14, No. 11, 21 March, 2002. 
A surge in online giving: internet donations doubled at many big charities, The Chronicle of Philanthropy, v. 17, n. 17, 2005.

After the flood: online gifts still flow to charities, but the stream slowed in 2007', The Chonicle of Philanthropy, v. 20, n. 17, 2008.

Still growing strong: online gifts to charities climbed 37 percent in 2006', The Chronicle of Philanthropy, v. 19, n. 17, 2007.

WASH, R.; Lampe, C. The Power of the Ask in Social Media. Poocedings of the ACM conference on Computer-Supported Cooperative Work (CSCW) Seattle, WA, p.11871190, 2012.

WATERS, R. D. Applying relationship management theory to the fundraising process for individual donors. Journal of Communication Management, p.73-87. 2008.

Measuring stewardship in public relations: A test exploring the impact on the fundraising relationship. Public Relations Review, v.35, n.2, p.113-119, 2009.

WEIR, L. ; S. HIBBERT, Building Donor Relationships: An Investigation into the Use Of Relationship and Database Marketing by Charity Fundraisers. The Service Industries Journal, v.20, n.2, p.114-32, 2000.

WEISBROD, B.A.; DOMINGUEZ, N.D. Demand for collective goods in private nonprofit markets: can fundraising expenditures help overcome free-rider behavior? J. Public Economy, v.30, p.83-96, 1986.

WORLD GIVING INDEX - Charity Aids Foundation (CAF), 2016. Publicação eletrônica. Disponível em https://goo.gl/Y94g2b Acesso em 2 de outubro de 2014.

WU, R. How to Get Started in Storytelling for Fundraising - Cara Jones Interview CauseVox. Disponível em: https://goo.gl/ZN4stV acesso em: 11/10 /2016.

YIN, R. Estudo de Caso. Planejamento e Métodos. 2 ed. São Paulo: Bookman, 2001. . Pesquisa Estudo de Caso. Desenho e Métodos. 2 ed. Porto Alegre: Bookman.1994.

ZHUANG J.; SAXTON, G. D.; WU, H.; Publicity vs. impact in nonprofit disclosures and donor preferences: a sequential game with one nonprofit organization and $\mathrm{N}$ donors, Annals of Operations Research, p. 221- 469, 2014. 


\section{Sites Consultados:}

ATADOS - https://www.atados.com.br

BENFEITORIA - https://benfeitoria.com

CATARSE - https://www.catarse.me/

CAUSE VOX - https://www.causevox.com

CLASSY - https://www.classy.org

CROWDRISE - https://www.crowdrise.com

EVERYDAY HERO

https://www.everydayhero.com

FACEBOOK - https://www.facebook.com

GOOGLE - https://www.google.com.br/

GOOGLE EARTH https://www.google.com.br/intl/ptPT/earth/

INSTAGRAM - https://www.instagram.com

IUGU - https://iugu.com/

JUNTOS.VC - http://www.juntos.com.vc

NEON - https://www.neoncrm.com

PAYPAL - https://www.paypal.com/

POLEN - http://opolen.com.br/

RISU - https://www.risu.com.br/

STRIPE - https://stripe.com/

TWITTER - https://twitter.com

VIMEO - https://vimeo.com/

WHATS APP www.whatsapp.com

YOUTUBE - https://www.youtube.com/ 


\section{APÊNDICES}

\subsection{Apêndice - Roteiro de Entrevistas Organizadores das Campanhas EVB}

Nome completo:

Link da campanha que

participou: Idade que fez a

campanha:

Data que criou a

campanha:

Nacionalidade:

Profissão:

Número de amigos no

facebook: Mídias sociais que

está ativo: Valor angariado:

Pessoas que doaram:

\section{ENGAJAMENTO ANTERIOR}

1) Você já conhecia outras ONGs antes de ter criado sua campanha no Eventos do Bem?

2) Você já doou ou fez qualquer atividade de voluntariado (etc) para outra ONG antes de sua campanha? Caso positivo, como foi a experiência?

\section{ENGAJAMENTO COM A ORGANIZAÇÃO APOIADA}

3) Como você conheceu a ONG apoiada?

4) Você chegou a se envolver mais antes da campanha? Doar, visitar, voluntariado na ONG apoiada?

5) Quando que você começou a realmente gostar da ONG apoiada? Você sabe citar as razões? Você acompanhava alguma coisa da ONG?

\section{INÍCIO DA CAMPANHA E PREPARATIVOS:}


6) Como você conheceu a possibilidade de criar uma campanha para o ONG apoiada?

7) Você se lembra do momento ou do porquê decidiu efetivamente criar essa campanha?

8) O que te motivou mais a criar a campanha, a ONG ou a causa dela?

9) Foi fácil criar a campanha?

10) Você criou algum material para a campanha antes de lançar ela? Qual?

11) Por que você escolheu o montante " $X$ " de meta?

12) No momento que você criou a campanha você recebeu algum auxílio do Eventos do Bem? Tipo um Kit, alguém te contatou, você teve e-mails que te auxiliaram?

\section{ASSESSORIA DA EVB}

13) Caso positivo, o que você foi auxiliado? Quais dicas recebeu? Quais dicas você usou?

14) Você recebeu algum retorno em captação de recursos pra sua campanha com essas dicas? Quais em específico realmente te ajudaram?

15) Na plataforma fica em aberto quem doou e quanto, você estava bem quanto isso ou viu que desmotivou alguma pessoa?

\section{INICIATIVA PESSOAL}

16) Tiveram, sacadas, ideias de divulgação que foram suas e você realizou? Quais?

17) Essas ideias surtiram efeito?

18) Você se considera uma pessoa com muitos contatos, na época que criou a campanha?

19) Como foi sua divulgação? Você divulgou em mídias sociais? Em quais?

20) Você chegou a falar pessoalmente com as pessoas (e-mail, whatsapp, telefone, ao vivo)?

21) Você criou algum vídeo de divulgação da campanha, post, e-mail, (recompensa)?

\section{PÓS CAMPANHA}

22) Tem algum ponto positivo a acrescentar nessa experiência? E negativo?

23) Você percebeu algum tipo de interação com seus amigos que mudou durante ou após a campanha? De engajamento social, eles se informaram mais sobre a causa ou criaram campanhas, foram voluntários etc. 
24) Que nota você daria para a experiência de doação que você teve no Eventos do Bem? Por que?

25) Você recebe e-mails frequentes do Eventos do bem? São relacionados a sua campanha?

26) Nos últimos 6 meses você chegou a doar para a ONG apoiada?

27) Você considera a ONG apoiada diferenciada? No que especificamente?

\subsection{Apêndice - Roteiro de Entrevistas: Organizadores das Campanhas CW}

Nome completo:

Link da campanha que

participou: Idade que fez a

campanha:

Data que criou a

campanha:

Nacionalidade:

Profissão:

Número de amigos no

facebook: Mídias sociais que

está ativo: Valor angariado:

Pessoas que doaram:

\section{ENGAJAMENTO ANTERIOR}

1) Você já conhecia outras ONGs antes do CW?

2) Você já doou ou fez qualquer atividade de voluntariado (etc) para outra ONG antes de sua campanha do CW? Se sim, como foi a experiência?

\section{ENGAJAMENTO NO CW}

3) Como você conheceu o CW?

4) Você chegou a se envolver mais antes da campanha? Doar, visitar, voluntariado na CW? 
5) Quando que você começou a realmente gostar da CW? Você sabe citar as razões? Você acompanhava alguma coisa da ONG?

\section{INÍCIO DA CAMPANHA E PREPARATIVOS:}

6) Como você conheceu a possibilidade de criar uma campanha para o CW ?

7) Você se lembra do momento ou do porquê decidiu efetivamente criar essa campanha?

8) O que te motivou mais a criar a campanha, a ONG ou a causa água?

9) Foi fácil criar a campanha?

10) Você criou algum material para a campanha antes de lançar ela? Qual?

11) Por que você escolheu o montante " $X$ " de meta?

12) No momento que você criou a campanha você recebeu algum auxílio do CW? Tipo um Kit, alguem te contatou, você teve e-mails que te auxiliaram?

\section{ASSESSORIA DO CW}

13) Caso positivo, o que você foi auxiliado? Quais dicas recebeu? Quais dicas você usou?

14) Você recebeu algum retorno em captação de recursos pra sua campanha com essas dicas? Quais em específico realmente te ajudaram?

15) Na plataforma fica em aberto quem doou e quanto, você estava ok quanto isso ou viu que desmotivou alguma pessoa?

\section{INICIATIVA PESSOAL}

16) Tiveram, sacadas, ideias de divulgação que foram suas e você realizou? Quais?

17) Essas ideias surtiram efeito?

18) Você se considera uma pessoa com muitos contatos, na época que criou a campanha?

19) Como foi sua divulgação? Você divulgou em mídias sociais? Em quais?

20) Você chegou a falar pessoalmente com as pessoas (e-mail, whats, telefone, ao vivo)?

21) Você criou algum vídeo de divulgação da campanha, post, e-mail, (recompensa)? 


\section{POSTERIOR A CAMPANHA - RELATÓRIO}

22) Quando sua campanha finalizou você recebeu algum tipo de relatório financeiro?

23) A CW te contatou de alguma forma para agradecer? Como?

24) Tem o tempo em que seu projeto vai criar o relatório, você recebeu e-mails nesse meio tempo da CW?

25) Tem algum ponto positivo a acrescentar nessa experiência? E negativo?

26) Quando chegou seu relatório você foi avisado?

27) O que achou do seu relatório?

28) Você percebeu algum tipo de interação com seus amigos que mudou durante ou após a campanha? De engajamento social, eles se informaram mais sobre a causa ou criaram campanhas, foram voluntários etc.

29) Que nota você daria para a experiência de doação que você teve na CW? Por que?

\section{PÓS RELATÓRIO}

30) Você recebe e-mails frequentes da CW? São relacionados a sua campanha?

31) Nos últimos 6 meses você chegou a doar para o CW?

32) Você considera a CW uma ONG diferenciada? No que especificamente?

\subsection{Apêndice - Roteiro de entrevistas com os funcionários do CW}

\section{APRESENTAÇÃO}

1) Qual o seu nome, idade e função.

2) $\mathrm{O}$ que você faz aqui no Charity:Water, descreva brevemente o que você faz na Organização.

3) Trabalha na Charity:Water há quanto tempo?

\section{SOBRE O QUE A CHARITY:WATER PODE AJUDAR AS ONGS}

3) Você acha que o modelo da Charity:Water é escalável para varias ONGs tipo o Crowdrise? Você teria algumas adaptações para ONGs?

4) Vimos que vocês fazem parte do Board do Classy, o que você fez para adaptar o modelo da Charity:Water nele?

5) Quais são os fatores que mais considera importante que ONGs façam para melhorar a 
cultura de doação?

\section{DINÂMICA DAS CAMPANHAS}

6) Vocês são bastante mencionados no storytelling das campanhas, como você acha que este quesito influencia o processo, de que modo influencia e o que vocês consideram como um fator muito importante que vocês abordam neste quesito.

7) Qual a história do Charity:Water, como foi que vocês foram validando hipóteses, percebendo as necessidades da plataforma e implementando melhorias?

8) No decorrer do desenvolvimento da plataforma e em suas diversas funções, tem alguma arquitetura de user experience que vocês implementaram e que viram resultado positivo nas campanhas? E negativo?

9) Como vocês se diferenciam pelo marketing? Que papel as mídias sociais tem na Charity:Water?

10) Vocês tem um ciclo de jornada do usuário? Caso positivo, como ele funciona? Paras as personas, organizador, apoiador e empresa.

\section{SOBRE O SUCESSO DAS CAMPANHAS}

11) Vocês consideram as campanhas de famosos boa para vocês em que aspectos?

12) Por que demora 21 meses para construir o poço?

13) Como vocês cobrem os credicard fees?

14) O ticket médio varia para cada tipo de evento?

15) Qual o papel dos times no sucesso das campanhas? Quando vocês perceberam a importancia dessa implementação na plataforma e por que?

16) Qual a importância do feedback para o sucesso de vocês? Como vocês perceberam essa importância e estruturaram todo o processo?

17) Acontece de vocês converterem doadores pontuais de campanhas em doadores recorrentes? É frequente? Vocês tem uma taxa de conversão?

18) O que você considera como uma campanha de sucesso? (é só dinheiro?)

19) Você vê diferenças no sucesso de uma campanha de crowdfunding convencional e em uma campanha de fundraising peer to peer? Caso positivo, quais?

20) Quais são os principais fatores que influenciam o sucesso das campanhas? 
21) Imagino que campanhas com categorias diferentes tenham dinâmicas diferentes, você pode me dizer um diferencial de:
a) Aniversários
b) Ocasiões especiais (casamento)
c) School Fundraiser
d) Eventos esportivos
e)Feriados
comemorativos
f) Empresas
g) Outras iniciativas criativas

22) Vocês fornecem algum apoio ou acompanhamento para os organizadores das campanhas (ex. kits, vídeos, e-mails) para ajudar a eles angariarem mais em suas campanhas? Caso positivo, você poderia me passar os que tem?

23) Vocês tem em algum lugar a lista das campanhas mais diferentes e criativas que tiveram?

24) Quais são seus outliers? (Campanhas que deram muito certo.. e campanhas que deram muito errado) Quais as razões disso, você teria hipóteses?

25) Vocês já tiveram campanhas que deram errado? O que quer dizer "dar errado "pra vocês (ex.não bater a meta etc).

26) Qual o papel da fotografia para vocês? vocês acham que isso influencia nas campanhas? Você tem algum exemplo de como o audiovisual ajudou vocês nas campanhas especificamente?

27) Vocês consideram que os eventos externos "charity ball" etc tem impacto direto no funcionamento das campanhas? São um must do?

\section{CHARITY:WATER E AS EMPRESAS}

28) Vocês ja fizeram matchfunding? Como foi?

29) Qual o papel das empresas nas campanhas peer to peer?

\section{CHARITY:WATER E AS ESCOLAS}


30) Como vocês trabalham com as escolas e de que forma isso tem impacto nas campanhas $\mathrm{P} 2 \mathrm{P} ?$

\section{SOBRE O IMPACTO NOS DOADORES}

31) As pessoas podem viajar e verem a sua campanha em campo? Qual o impacto disso nelas, pensando no quesito de engajamento social?

32) Vocês notam algum impacto ou mudança de comportamento nos seus doadores das campanhas? e organizadores?

\section{SOBRE O DESIGN DA CHARITY:WATER}

33) Como vocês elaboraram a proposta de branding do Charity:Water? Você pode me explicar um pouco sobre o processo?

\section{SOBRE A PÁGINA DO CHARITY:WATER DAS CAMPANHAS}

34) É importante ter metas nas campanhas? Vocês já tentaram sem meta?

35) E sobre colocar a lista de doadores e o valor? Isso não deixa as pessoas constrangidas?

36) Quais são os atributos da página de vocês que vocês consideram mais importantes?

37) Percebi que o vídeo não é tão colocado em foco no layout da $\mathrm{CW}$, por que?

38) Percebi que o texto não é tão colocado em foco no layout da $\mathrm{CW}$, por que?

39)

\section{SOBRE O MODELO DE NEGÓCIO DA CHARITY:WATER}

40) O modelo de $100 \%$ das doações irem para o projeto que vocês abordam é bem interessante, você considera ele como um dos fatores que determinam o sucesso das campanhas? Na experiência anterior quando não era $100 \%$ teve gente que deixou de doar? 41) Como vocês conseguem repor os credicards fees? No começo vocês tinham alguma reserva financeira pra isso? Foi por investimento externo? Por que na Eventos do Bem somos um negócio social, temos lucro. Acha que é possível que consigamos isso tb ou só funciona pra ONGs.

42) O ticket médio varia por tipo de evento? Quais os eventos que angariam mais e quais menos? 